



\section{The Dhaka Water \\ Services Turnaround}

How Dhaka is connecting slums, saving water, raising revenues, and becoming one of South Asia's best public water utilities

Manoj Sharma and Melissa Alipalo 
(C) 2017 Asian Development Bank

6 ADB Avenue, Mandaluyong City, 1550 Metro Manila, Philippines

Tel +63 2632 4444; Fax +6326362444

www.adb.org

Some rights reserved. Published in 2017.

ISBN 978-92-9261-024-1 (print), 978-92-9261-025-8 (electronic)

Publication Stock No. TCS179117-2

DOI: http://dx.doi.org/10.22617/TCS179117-2

The views expressed in this publication are those of the authors and do not necessarily reflect the views and policies of the Asian Development Bank (ADB) or its Board of Governors or the governments they represent.

ADB does not guarantee the accuracy of the data included in this publication and accepts no responsibility for any consequence of their use. The mention of specific companies or products of manufacturers does not imply that they are endorsed or recommended by ADB in preference to others of a similar nature that are not mentioned.

By making any designation of or reference to a particular territory or geographic area, or by using the term "country" in this document, $A D B$ does not intend to make any judgments as to the legal or other status of any territory or area.

This work is available under the Creative Commons Attribution 3.0 IGO license (CC BY 3.0 IGO)

https://creativecommons.org/licenses/by/3.0/igo/. By using the content of this publication, you agree to be bound by the terms of this license. For attribution, translations, adaptations, and permissions, please read the provisions and terms of use at https://www.adb.org/terms-use\#openaccess

This CC license does not apply to non-ADB copyright materials in this publication. If the material is attributed to another source, please contact the copyright owner or publisher of that source for permission to reproduce it. ADB cannot be held liable for any claims that arise as a result of your use of the material.

Please contact pubsmarketing@adb.org if you have questions or comments with respect to content, or if you wish to obtain copyright permission for your intended use that does not fall within these terms, or for permission to use the ADB logo.

Notes:

In this publication, "\$" refers to US dollars.

Corrigenda to ADB publications may be found at http://www.adb.org/publications/corrigenda 


\section{Turnaround}

noun turn around $\backslash$ - raūnd $\backslash$

a complete change from a bad situation to a good situation, from one way of thinking to an opposite way of thinking, etc.

Source: Merriam-Webster's Learner's Dictionary 
"We were a

water-crisis city.

It was a very

difficult period,

and we

needed a total

turnaround."

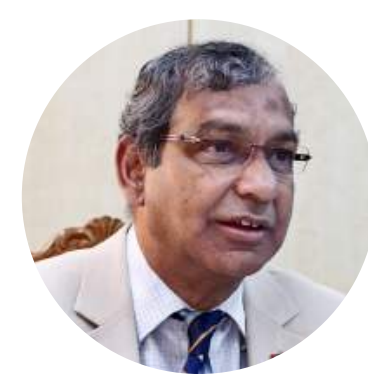

Taqsem Khan, managing director, Dhaka Water Supply and Sewerage Authority

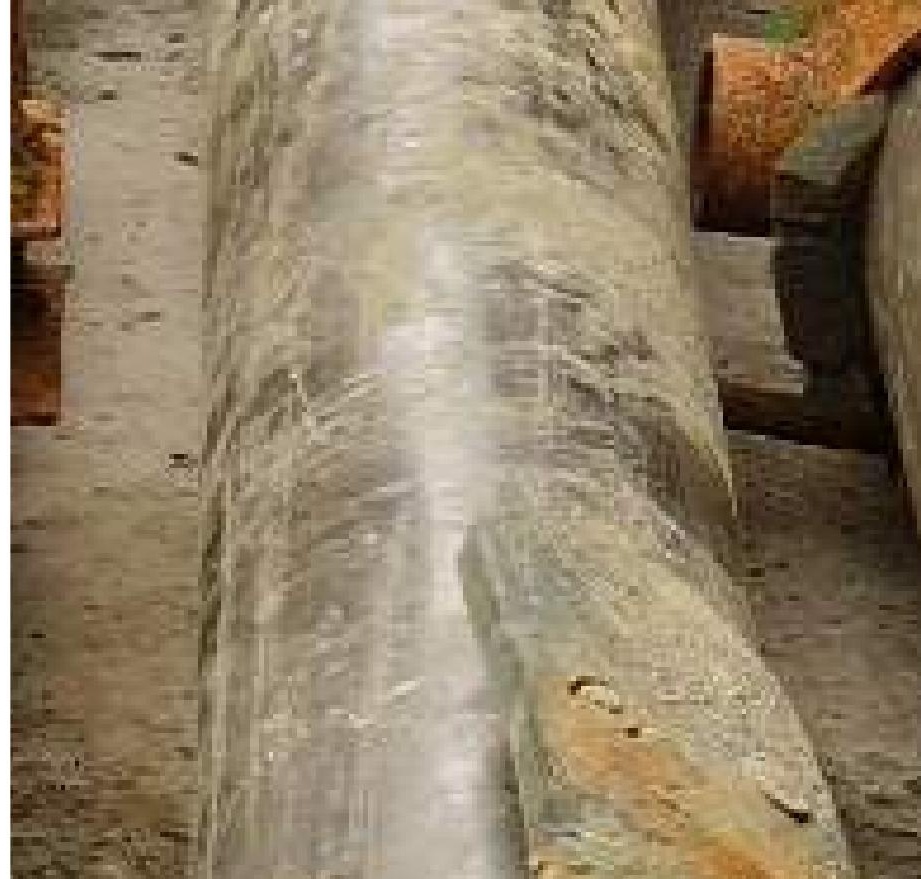




\section{Contents}

2 Foreword

5 The Dhaka Turnaround Story

8 A City, A Utility in Water Crisis

15 Sector Turnaround

18 Turning Points

19 System Turnaround

22 District Metered Areas:

The Momentum for DWASA's Turnaround

28 How Trenchless Technology Became the Status Quo

31 Connecting the Poor: A Game-Changer for DWASA

39 Service Turnaround

40 New Vision, Mission

40 Training a Pro-People Workforce

44 Financial Performance over Politics

46 Transparency and Customer Relations

47 DWASA Breaks Ground with Self-Initiated Gender Strategy

50 NGOs Fill Unique Role, Make Distinct Contribution as Communicators

55 Future Turnaround 


\section{Acknowledgments}

This publication was written by Manoj Sharma, principal urban development specialist, Urban Development and Water Division, South Asia Department (SARD), and Melissa Howell Alipalo, knowledge solutions specialist for the water sector (consultant).

The project management office for the Dhaka Water Supply Sector Development Program, Bangladesh, provided highly valued information, cooperation, and guidance. Thanks are especially due to Taqsem Khan, managing director, Dhaka Water Supply and Sewerage Authority (DWASA); Shahid Uddin, then project director and chief engineer, DWASA; and Md. Kamrul Hasan and Md. Mahmudul Islam, present DWASA project directors.

Former project staff-particularly Tomoo Ueda, principal evaluations specialist, Independent Evaluations Department; Masayuki Tachiiri, principal planning and policy specialist; Norio Saito, deputy country director, Viet Nam Resident Mission; and Md. Rafiqul Islam, former ADB staff-all offered singular insights into the early stages of the project as well as archival images. Akira Matsunaga, Suzanne Barbin, and Jade Marie Dumaguing of the Urban Development and Water Division, SARD, and colleagues in the Urban and Water Sector groups, particularly Ellen Pascua and Pia Reyes, reviewed the content and extended the support of the ADB-managed Water Financing Partnership Facility to the publication team.

The editorial team was directed by Melissa Howell Alipalo (writer) and comprised Mohammad Rakibul Hasan, photographer; Randolph L. Perez, graphic design and layout artist; Tim Alipalo, video editor; and Mary Ann E. Asico, editor. They are grateful for the welcome shown them by the project implementing consultants and DWASA staff, and by the people of Korail and Shattola slums, who shared their stories of the project's impact on their work and lives.

Finally, this publication would not have been possible without the guidance and encouragement of Hun Kim, director general, SARD; Sekhar Bonu, director, Urban Development and Water Division, SARD; and from the Bangladesh Resident Mission, Kazuhiko Higuchi, country director, and Zahir Uddin Ahmad, senior water resources officer. 



\section{Foreword}

This publication features a project that turned around an urban water utility in South Asia, and offers a good example for other similar utilities in South Asia. ADB's support to the Dhaka Water Supply and Sewerage Authority (DWASA) provided a breakthrough in the delivery of clean, reliable, affordable, and continuous water to the residents, including the poor, in Dhaka. This is not just a breakthrough for Dhaka or the rest of Bangladesh, but for the region of South Asia, which struggles with the lowest service levels for safe drinking water and where continuous water supply is an exception rather than a norm in most cities.

This publication looks at the key success factors that other utilities are taking note of: the zonal approach to rehabilitating and managing urban water services, trenchless technology for expeditiously laying pipes, the importance of community mobilization, and connecting the urban poor-and keeping them connected-through communitymanaged approaches. ADB invested $\$ 212.7$ million in the Dhaka Water Supply Sector Development Program to bring reforms to Bangladesh's urban water services sector, build capacity of Dhaka's water utility, and to reach out to the poor and slums. ADB's investment was critical part of a multi-donor partnership to bring investments to the entire urban water sector in Bangladesh.

The situation before the project was clearly suboptimal: lack of surface water had led to unsustainable reliance on groundwater; the city did not have the infrastructure to deliver clean or $24 \times 7$ water supply nor could it do that with high water losses and the proliferation of suction pumps that the public had resorted to using as a coping mechanism. The ADB investment supported the "district metering area approach," which divided the city into zones with independent systems that could manage flow and pressure, and control nonrevenue water or water losses. This approach expedited the rehabilitation of the entire city and was supported by trenchless 

the

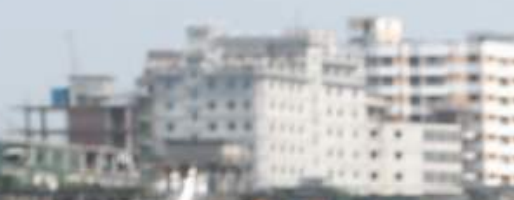

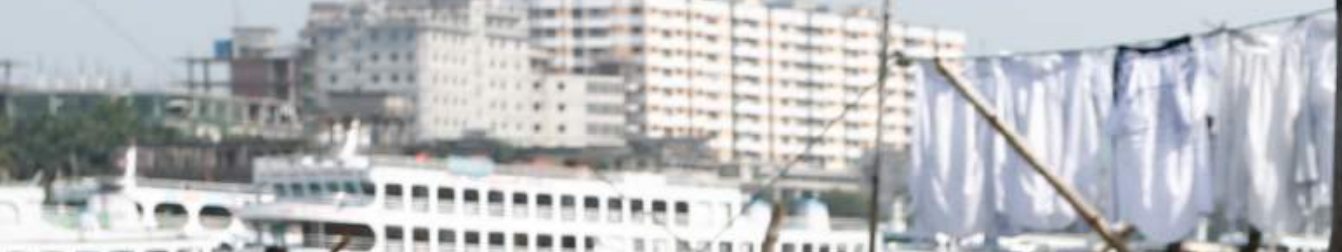
$z^{2}$

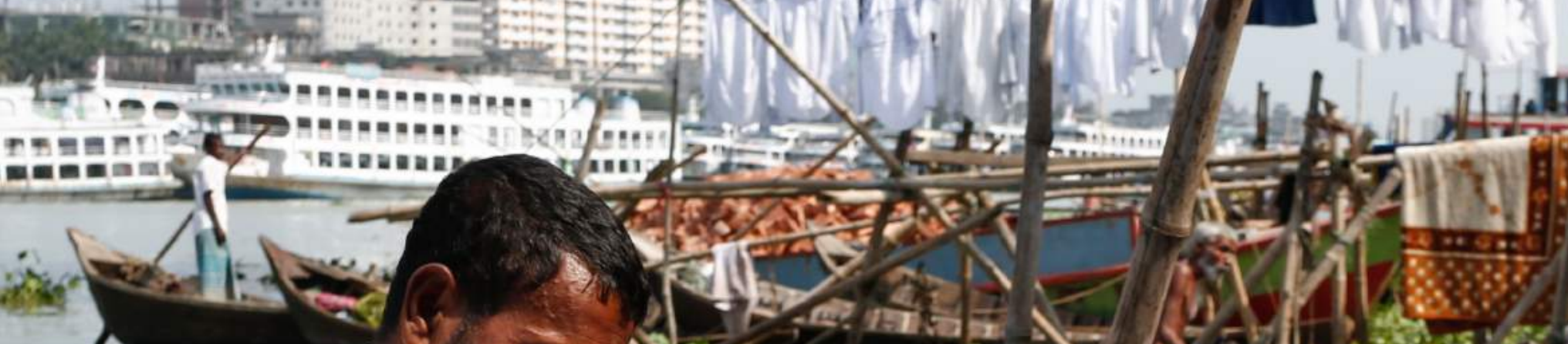
xista

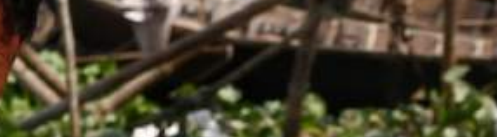

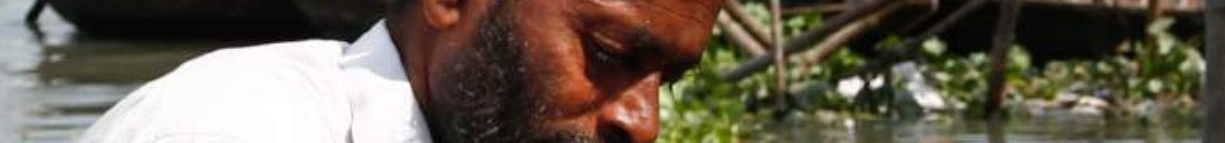

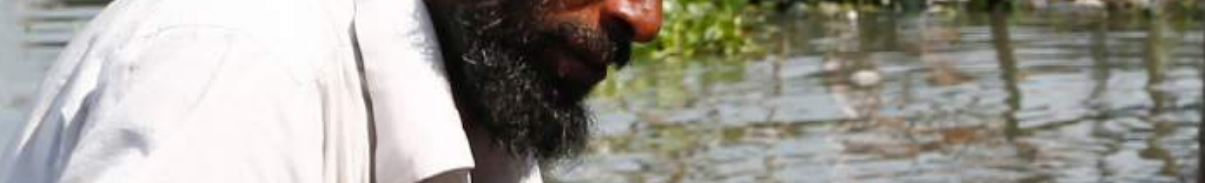
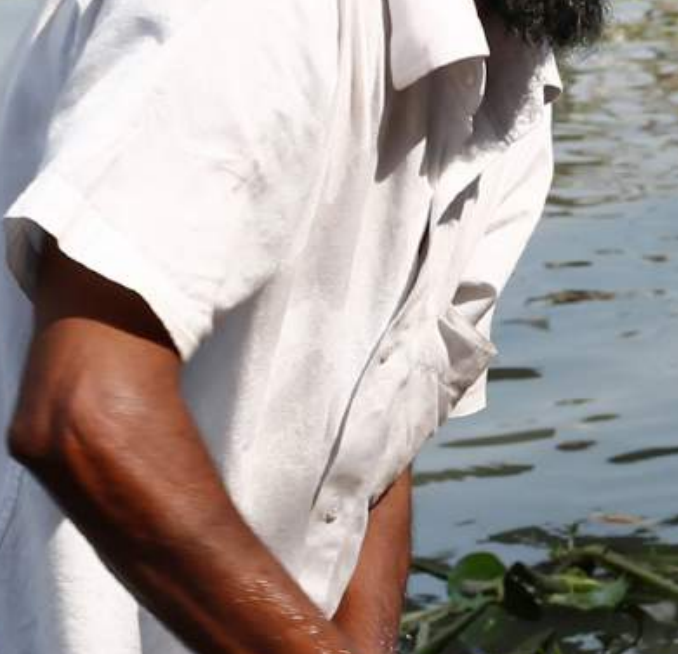

$\frac{15}{1}=$

(5)

A 2

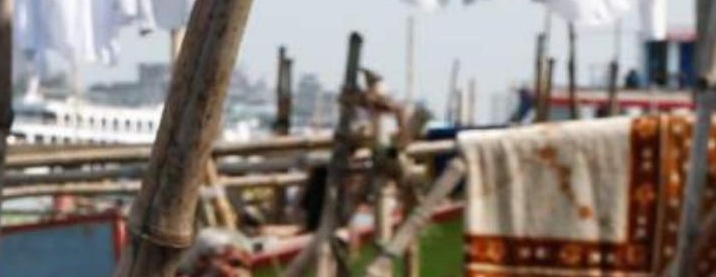

(1) s. 3 is 25 . Don 3 

Cities across South Asia have begun turning to DWASA to learn about its technology and tactics, and replication is under way. "This is South-South learning at its best," says Manoj Sharma, the ADB project manager who worked with DWASA for 6 years through its least hopeful to its shining moments. The multilateral development banks, including $\mathrm{ADB}$, are also learning that investments in water distribution networks, and not only in bulk water supply, provide surety that the investments do not just speak for the poor but deliver the benefits of development dollars directly to them. Rather than simply pushing a loan condition, ADB took a more direct and proactive role in connecting urban poor households in Dhaka. Project designers cannot assume that networks will be extended to the poor. Design must be deliberate-not just "pro-poor" but for-the-poor design, implementation, monitoring, and evaluation.

Through the DWSSDP and a unique collaborative landscape of development partners working to support DWASA's turnaround, DWASA is demonstrating how utilities can become government standard-bearers, both financially and in service to the public. Nongovernment organizations (NGOs) are finding their optimal role as facilitators rather than the small-scale development contractors that many have become, and the poor are proving to be a financially viable market that can also deliver their own development when basic social services are accessible. Once connected, communities invest in more durable housing, community assets, and sanitary environments. Pathways are paved; household and community toilets are built and maintained. Water inspires work. It encourages investments and construction, and sparks community pride.

Political and management commitment to connect the poor also begets new technical and management approaches. Legal work-arounds can sidestep prohibitions on connecting residents without land titles. Technical solutions can master even the most challenging urban terrain. Slums can, and must be, connected. To exclude them, to build systems exclusively for the politically, technically, and financially low-risk customer, incites the poor to rationalized theft to correct social injustice and inequality, causing its own set of technical and financial problems for utilities and privileged customers. Illegal connectionsand in Dhaka's case, the proliferation of suction pumps-can compromise the pressure and quality of water and its availability to all, and impair the performance of the larger system. Investing in systems for the poor is investing in systems for everyone.

The question for utilities is not why 24-hour water supply should be provided or why the poor should be connected. The advantages of 24-hour water supply compared with intermittent water supply are acknowledged by most top-level managers, who also know that access to clean drinking water and sanitation is a basic, universally declared human right. ${ }^{1}$ The question, rather, is how these seemingly formidable challenges can be surmounted, and everyone, including the poor, assured of 24-hour water supply, without exposing the utility (or its management) to political targeting or to further technical and financial strain. Taking such an obligation seriously is another matter, but one that concerns the most successful utilities as it has DWASA.

This publication tells Dhaka's success story. It narrates how a nearly bankrupt, dysfunctional utility became one of South Asia's leading public utilities, and how ADB and other partners helped make the turnaround possible, by daring to engage in development differently. 


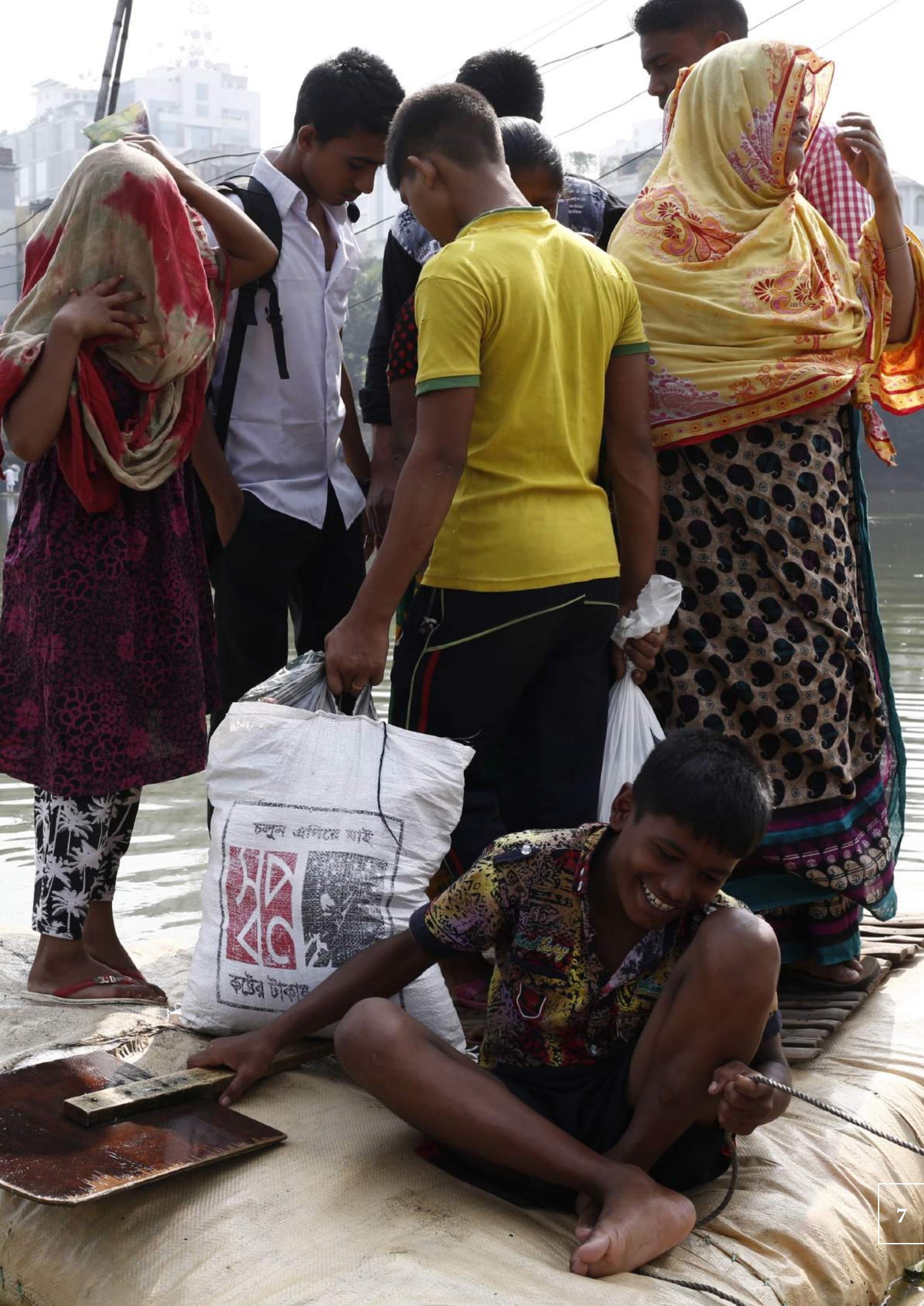




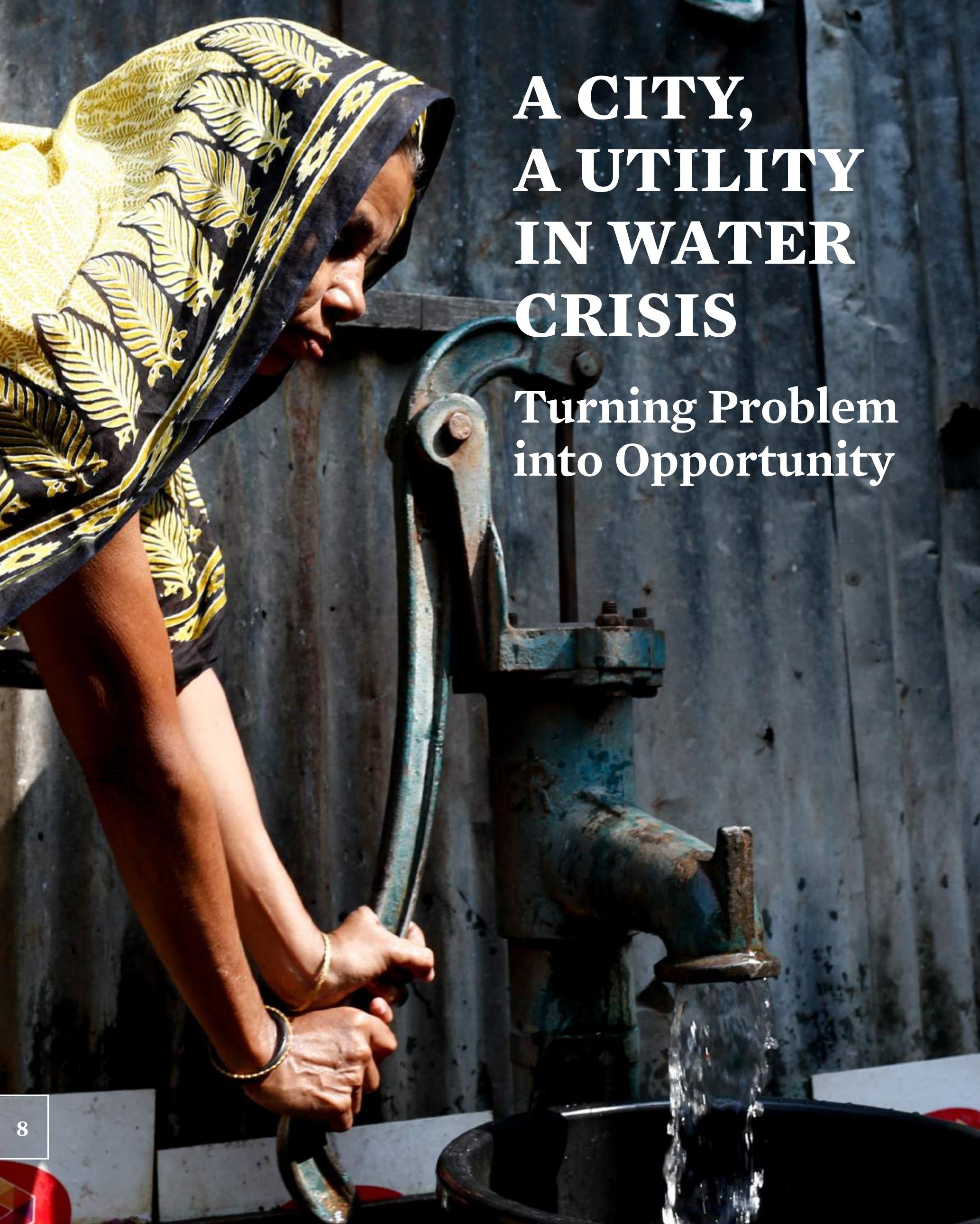


In 2006, when ADB began seriously considering investing in DWASA, Dhaka was ailing and weighed down by decades of too little progress in the city's water infrastructure development and governance. The country's $5 \%$ growth rate depended on its cities and, by default, the utilities that supported urban growth: energy, water, and transportation. Dhaka, the sixth-largest megacity in the world, was barely getting by on piped water supply that was unsanitary and often unavailable, and an every-man-for-himself scramble for groundwater. "We were a water-crisis city," says Taqsem Khan, DWASA's managing director. "It was a very difficult period. We needed a total turnaround."

Waterborne diseases were killing infants and children below 5 years old. Where water is scarce and what is available is often of poor quality, sanitation is always worse. More than $26 \%$ of households in Dhaka, most of them slum households, had no sanitary toilets and $70 \%$ of the city had no form of sewerage. "We had a permanent booking at the cholera hospital," a resident of Shattola slum, Aisha Aktar, says. Using information from the country's cholera experts, the World Health Organization reported that the entire population of Bangladesh, without exception, was at risk of cholera because of frequent and widespread flooding resulting from the country's low elevation and tropical monsoons. $^{2}$

The city, which obtains $80 \%$ of its water supply from groundwater, was also practically undermining that resource with marathon, round-the-clock pumping. Suction pumps, installed beneath underground tanks, reduced or choked off pressure elsewhere in the system, causing backwashing and stagnation, and hence contamination. Leaky pipes could likewise let contaminants into the water flowing through the pipes. ${ }^{3}$

Groundwater is cheaper to supply than surface water, but only until it is too far gone. Then it is priceless. Aquifers take half-centuries to recover from overuse, if they ever do, and Dhaka's are on the brink. As early as 2000, the city had already surpassed the limits of its upper aquifer, and the lower aquifer could accommodate only about 50 new tube wells. Almost half of the deep tube wells supplying the city are seriously threatened: 40-60 dry up yearly. The water table is falling by $2-3$ meters each year. "Sure, we wanted surface water," Taqsem, DWASA's managing director, declares. "But that takes a lot of financing, and to get it I needed to convince the banks their money was good with us and our investments."

Dhaka was running out of water and time, and the government knew it. In 2005, the government listed water supply and sanitation among seven priorities in its National Poverty Reduction Strategy. The strategy was aligned with the United Nations Millennium Development Goals, which included halving the number of people without access to safe drinking water and better sanitation (26\%) by 2015. In its 2006 sector development plan for water supply and sanitation, the government outlined its citizens' basic entitlements, the way in which utilities should operate, and

2 Mohammad Ali, Anna Lena Lopez, Young Ae You, Young Eun Kim, Binod Sah, Brian Maskery, and John Clemens. 2012. The Global Burden of Cholera. Bulletin of the World Health Organization 90(3): 209-218. http://www.who.int/bulletin/volumes/90/3/11-093427/en/

Elsewhere in the country, arsenic is leaching into the groundwater, but in Dhaka the threat is not significant.

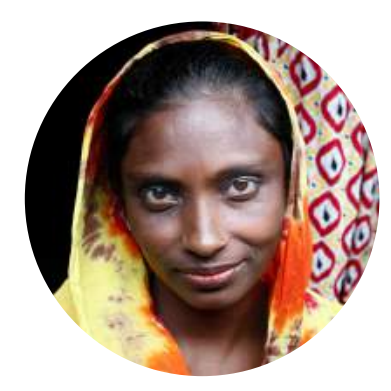

\section{"We had a permanent booking at the cholera hospital."}


the financial needs. It did not take long for the government to realize that the plan was overly ambitious and that it lacked specific strategies, funding allocations, a timetable, institutional arrangements, legal instruments, and policy directives to turn aspirations into reality.

Even with a semblance of an enabling environment, DWASA was considered unfundable (see "DWASA's Six Core Problems Shared by Other Urban Utilities in Asia" box on this page). It could not control leaks, collect payments from users, or manage its own assets and workforce effectively. The typical household connection was substandard and leaky. Only $59 \%$ of homes had water meters, and those were often inaccurate or inaccessible to meter readers. Surveys showed that $90 \%$ of slum dwellers were using DWASA-supplied water through illegal channels. Physical losses topped 50\%; with improper metering, in a low-pressure, intermittent supply system, those losses were difficult to quantify accurately. As for the water that did reach consumers, DWASA was collecting only $62 \%$ of revenues. In total, only one-third of the water entering the system was ever paid for.

DWASA's management systems were outdated, inefficient, and opaque. Leadership and management was wanting in many areas, and rank-and-file employees were unionized to a debilitating degree. Customers had little access to staff, who in turn had scant interest in, or capacity for, their roles or responsibilities. Resources of all kinds were not planned, allocated, or monitored.

DWASA was also suffering a bruised reputation after the World Bank canceled a loan because of procurement irregularities. The World Bank had invested \$147 million in DWASA in nearly back-to-back loans since 1973. As a whole, DWASA was a high-risk investment for any development partner to even consider investing in, given its irrationally low tariffs, uncommercial practices, uncoordinated investments, and

\section{DWASA's Six Core Problems Shared by Other Urban Utilities in Asia}

Although urban areas differ in size within Bangladesh and across South Asia, the issues and challenges that the Dhaka Water Supply and Sewerage Authority (DWASA) has faced are common to the urban water supply and sanitation sector in general. When the investment program of the Asian Development Bank (ADB) began in 2007, DWASA had to deal with six issues in particular:

1 Inadequate supply of clean water to meet rapidly growing demand

More than $80 \%$ of Dhaka's water supply comes from groundwater, but by 2007 the upper aquifer of Dhaka had already exceeded its withdrawal limit. As a result, almost half of the deep tube wells supplying water to Dhaka were expected to dry up by 2013. The lower aquifer could accommodate only about 50 new tube wells. The groundwater supply inevitably and urgently needed to be augmented with treated surface water. However, treating surface water is much more technically complex and expensive than using groundwater.

2 Poor quality of water distribution network and high water losses

A pilot program in Manikdi area revealed that household connections were substandard and leaking, and that physical water losses-under very low pressureamounted to more than $50 \%$. The 
network could not sustain the higher pressure required to supply continuous treated water. Besides losses due to leaks, only $59 \%$ of household connections had water meters to measure consumption, and the installed meters were often inaccurate or inaccessible, making demand virtually impossible to manage effectively.

\section{Low quality and reliability of water supply and poor service delivery}

The quality of groundwater pumped into Dhaka's water supply network was believed to be good, but it deteriorated as the water moved through the piped network. The problem was due to several reasons. Leaks impaired hygiene in pipes and connections. To a greater degree, the system's low, and sometimes negative, pressure-resulting from the use of suction pumps installed beneath underground tanks-caused extensive contamination of the water in the network. Intermittent supply worsened the problem by creating a vacuum in the absence of supply, leading to contamination. The treatment plants for surface water were not working optimally and required pretreatment facilities. Water quality aside, the reliability of supply was severely hampered by intermittent power supply to the pumps, especially without backup generators.

\section{(4) Limited coverage of slum dwellers}

In 2007 , about 1.3 million people (or $15 \%$ of the population) in the DWASA service area were living in slums, many with unauthorized connections. A significant number of the more vulnerable slum dwellers did not have even illegal access to water services. Without an intervention or change in policy and service commitment, the number of slum dwellers without water services in Dhaka was projected to exceed 4 million by 2025.

\section{Financially unsustainable utility}

Network hemorrhage, meter defects and obsolescence, and water pilferage were robbing DWASA of much-needed revenues for rehabilitation, regular operation and maintenance, and expansion. The tariffs were also far less than the cost of providing the service and the accounting and management systems were outdated, inefficient, and often not transparent. Only half of the water supplied to the networks was ever billed (accounted for), and only 62\% of water billed was ever collected. In total, only one-third of the water that entered the network was ever paid for.

\section{Inefficient and ineffective management systems}

DWASA and its operations were highly politicized. The managing director position was vacant for long periods, as a result, and turnover among senior executives (including the managing director) was high. Labor unions exerted strong pressure on management, often preventing them from recruiting key staff or taking disciplinary action. Staff capacity and motivation were low. Customer interface was extremely limited. DWASA's management systems and structure barely allowed for effective planning, allocation, and monitoring of resources. Consequently, DWASA had difficulty serving its customers effectively. 
poor reputation among development partners. But not to take that risk on DWASA was to strand millions of people amid a growing risk of disease, diminished incomes, and a daily frustration that takes its civic toll.

"The water situation was getting worse by the month," recalls Tomoo Ueda, an ADB staff working in the early days of the project in Dhaka. "The groundwater table was falling, sinkholes were starting to develop, and everyone was paying a lot of money for electricity to pump water or buy water. Even the wealthy were feeling the pinch by this time."

DWASA's total mandate-water supply, sanitation, and drainage-required an investment of more than $\$ 1$ billion, according to Taqsem. Although ADB had not invested in DWASA since 1996, its leadership saw this as an opportunity if the investment could be packaged with reforms and if the other major development partners could get behind it.

"In the beginning, there was only ADB during that difficult period," Taqsem says of what he knew and was told of those times, before he joined DWASA. "But they led the partnership framework and worked very hard at implementing the DMA approach to reduce nonrevenue water (NRW), supply water $24 \mathrm{x} 7$, and connect the low-income communities. We give them credit for that."

"The donors were there, each with its own budget and strengths and interests," Rafique Islam, a longtime project officer at ADB's Bangladesh Resident Mission, points out. "All wanted a presence in DWASA, but nobody was really sure how to take the next step."

To make good use of the momentum building in DWASA's favor, the ADB country director at the time gathered together the heads of other interested development partners in Dhaka to get their commitment to the urban water sector down on paper through a partnership agreement and an investment road map. Development partner assistance in the government's reform actions and with investment loans was coordinated. A partnership agreement was signed with the government. ADB would take the lead in investing in water supply improvements, while the World Bank focused on sewerage and drainage with a $\$ 100$ million loan and partnered with the United Kingdom's Department for International Development (DFID) in scaling up successful service models for low-income communities and slums in Dhaka. The Danish International Development Agency (Danida) would provide $\$ 130$ million for a new surface water treatment plant in Dhaka. Urban water supply in Chittagong, on the other hand, would be the concern of the Japan Bank for International Cooperation (JBIC), the Korea International Cooperation Agency (KOICA) ${ }^{4}$, the Government of Italy, and the World Bank.

In designing new investments in DWASA, ADB drew on valuable lessons from implementing projects elsewhere in Bangladesh to hedge against the risk of investing in DWASA (see "ADB Lessons from Experience Applied to the Design of the Dhaka Water Program" box on page 14). Also building on the synergies between policy reforms and infrastructure development, ADB's design for the DWSSDP combined a policy-based loan, to catalyze policy reforms, and a project loan, to provide funds for infrastructure investments, in an instrument called "sector development program." "It's a way of keeping infrastructure projects on time, on schedule, and on target, while leveraging the policy reforms to create an enabling environment,“ sums up Suzanne G. Barbin, associate project officer, ADB's South Asia Department (SARD). Echoes Manoj Sharma, SARD project officer: "With critical knowledge and insights gained from the DWSSDP, we've designed and are implementing a similar, highly successful project in Rajasthan, India, that combines infrastructure investments with policy reforms." 
ADB's ultimate goal in investing in DWASA was to help unclog the urban economy and improve public health conditions. The unreliable supply of clean water, a basic need for everyday living and industry, was a constraint on growth. But a successful major investment would reduce child mortality (which is costly in every way for families and the health system) and improve general health and women's productivity, especially by cutting the time and the effort needed to fetch and store water and care for family members with waterborne diseases. A successful investment would also help ease groundwater depletion and reduce the waste from pipe leakage and "They built toilets in the school after the project, at their own cost." water theft.

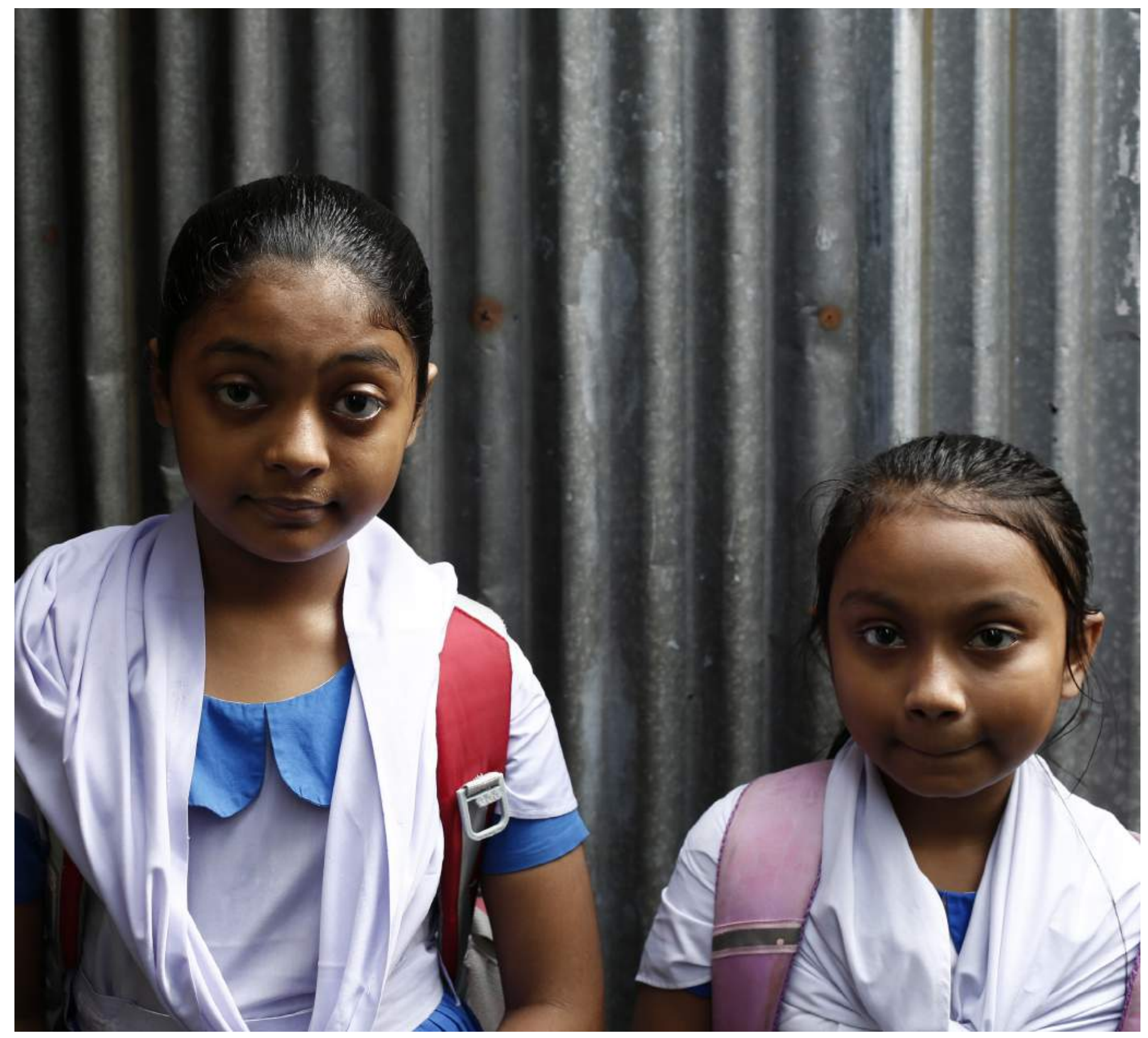




\section{ADB Applies Lessons \\ to Design of Dhaka Water Program}

The Asian Development Bank (ADB) mitigated the risks of investing in the Dhaka Water Supply and Sewerage Authority (DWASA) by designing the Dhaka Water Supply Sector Development Program (DWSSDP) with four key lessons in mind. The lessons were derived from previous investments in Bangladesh and documented by project officers.

\begin{tabular}{|c|c|}
\hline Lesson & Applied to DWSSDP Design \\
\hline $\begin{array}{l}\text { Use phased, performance-based funding } \\
\text { to motivate executing and implementing } \\
\text { agencies to keep projects on schedule. }\end{array}$ & $\begin{array}{l}\text { Disbursements were timed to coincide } \\
\text { with the achievement of performance } \\
\text { milestones. The program comprised a } \\
\$ 50 \text { million program loan disbursed over } \\
\text { two tranches to cover sector reforms, } \\
\text { and policy conditions and actions; a } \$ 150 \\
\text { million project loan to cover infrastructure } \\
\text { rehabilitation and construction; and } \$ 2.5 \\
\text { million technical assistance grant. }\end{array}$ \\
\hline $\begin{array}{l}\text { Prioritize the financial performance } \\
\text { and autonomy of local water supply } \\
\text { bodies through double-entry accounting } \\
\text { systems, separate water supply accounts, } \\
\text { staff training, and support for the move } \\
\text { to public-limited-company operating } \\
\text { models. }\end{array}$ & $\begin{array}{l}\text { Of the two DWSSDP loans, the first } \\
\text { required policy, sector, regulatory, legal, } \\
\text { and institutional reforms. At the same } \\
\text { time, infrastructure works were to be } \\
\text { implemented under the second loan. }\end{array}$ \\
\hline $\begin{array}{l}\text { Minimize processing and } \\
\text { implementation delays by offering fewer } \\
\text { contracts and procurements. }\end{array}$ & $\begin{array}{l}\text { The project loan (infrastructure } \\
\text { investments) covered only six major } \\
\text { contracts for civil works to improve } \\
\text { the distribution network. Limiting the } \\
\text { number of contracts tended to increase } \\
\text { administrative efficiency. Moreover, each } \\
\text { one was designed as a } \\
\text { performance-based contract, where } \\
\text { contractors were paid according to their } \\
\text { ability to meet stipulated performance } \\
\text { criteria (nonrevenue water reduced to } \\
\text { a desired level and continuous supply } \\
\text { provided). }\end{array}$ \\
\hline $\begin{array}{l}\text { Engage local community involvement } \\
\text { through extensive consultations to } \\
\text { ensure stronger commitment and } \\
\text { smoother implementation. }\end{array}$ & $\begin{array}{l}\text { DWASA contracted with nongovernment } \\
\text { organizations with credibility and } \\
\text { experience in slum areas to disseminate } \\
\text { information about the project, and } \\
\text { organized water user groups to manage } \\
\text { the new piped water supply networks to be } \\
\text { built in their areas and manage collections. }\end{array}$ \\
\hline
\end{tabular}




\section{SECTOR}

\section{TURNAROUND}

;

\section{Dhaka-centric}

\section{Investment}

\section{Pushes Reforms}

\section{across the Sector}

The policy-based loan centered on an ambitious reform program to improve the entire urban water sector and provide fundamental support for the DWASA turnaround-all before civil works for Dhaka began under the project loan (infrastructure loan). The policy-based loan was intended to enable all urban water supply institutions, not just DWASA, to operate more effectively and sustainably.

The reform program rested on four broad pillars:

- improving local governance and strengthening the local institutional framework;

- preparing a sector strategy for demand-side management;

- improving financial sustainability; and

- strengthening DWASA's governance, organizational structure, and financial management capacity.

The table on the next page summarizes the 14 policy conditions that formed the backbone of the program loan. All 14 conditions have been met, and 13 other policy actions directed at strengthening water resource conservation and governance have generally been achieved. 


\section{Policy Conditions Behind the Program Loan}

\begin{tabular}{|c|c|c|}
\hline Area for Reform & Policy Mandate & Results \\
\hline \multirow[t]{3}{*}{$\begin{array}{l}\text { LOCAL } \\
\text { Strengthen local water } \\
\text { governance and institutional } \\
\text { framework }\end{array}$} & $\begin{array}{l}\text { POLICY CONDITION } 1 \\
\text { Decentralize and give broader } \\
\text { autonomy to water utility } \\
\text { operation and maintenance } \\
\text { (O\&M), billing and collection, } \\
\text { and tariff setting. }\end{array}$ & $\begin{array}{l}\text { Accomplished through a series } \\
\text { of new regulations, rules, } \\
\text { and acts, and the creation of } \\
\text { specialized agencies for larger } \\
\text { urban utilities. } \\
\text { Utilities also became more } \\
\text { aware of and exercised their } \\
\text { lawful mandates and powers. }\end{array}$ \\
\hline & $\begin{array}{l}\text { POLICY CONDITION } 2 \\
\text { Recommend to the Cabinet } \\
\text { (based on thorough study) } \\
\text { the most appropriate form } \\
\text { of water supply regulator } \\
\text { for Bangladesh, clarifying } \\
\text { the functions, roles, and } \\
\text { responsibilities of the regulator. }\end{array}$ & $\begin{array}{l}\text { The Local Government } \\
\text { Division (LGD) formally } \\
\text { approved a two-stage process, } \\
\text { accomplishing the first stage } \\
\text { of establishing a regulatory } \\
\text { cell within its policy support } \\
\text { unit and committing to the } \\
\text { second stage of establishing an } \\
\text { independent regulator. }\end{array}$ \\
\hline & $\begin{array}{l}\text { POLICY CONDITIONS } 3 \\
\text { AND } 4 \\
\text { Prepare a sufficient budget } \\
\text { for and implement a 5-year } \\
\text { capacity building program for } \\
\text { program for all local water } \\
\text { utility staff. }\end{array}$ & $\begin{array}{l}\text { Appropriately endorsed plans } \\
\text { are providing systematic } \\
\text { strategies for human resource } \\
\text { development, which are based } \\
\text { on a training needs assessment } \\
\text { and accompanied with training } \\
\text { modules to ensure high-quality } \\
\text { capacity building in the areas of } \\
\text { - general management, } \\
\text { - business and finance, } \\
\text { - information technology, } \\
\text { - technical subjects, and } \\
\text { - public awareness. }\end{array}$ \\
\hline $\begin{array}{l}\text { FINANCIAL } \\
\text { Improve financial sustainability }\end{array}$ & $\begin{array}{l}\text { POLICY CONDITION } 5 \\
\text { Allow local water utilities } \\
\text { (pourashavas) to keep and use } \\
\text { their water billing revenues, } \\
\text { provided they comply with } \\
\text { separate accounting for water } \\
\text { revenues and double-entry } \\
\text { bookkeeping, and maintain } \\
\text { an inventory of water supply } \\
\text { assets. }\end{array}$ & $\begin{array}{l}2009 \text { LGD circular, supported } \\
\text { by appropriate administrative } \\
\text { instruments, fulfilled the } \\
\text { requirements of this policy } \\
\text { condition. }\end{array}$ \\
\hline $\begin{array}{l}\text { Dhaka Water Supply } \\
\text { and Sewerage Authority } \\
\text { (DWASA) } \\
\text { Strengthen DWASA } \\
\text { governance, organizational } \\
\text { structure, financial } \\
\text { management capacity }\end{array}$ & $\begin{array}{l}\text { POLICY CONDITION } 6 \\
\text { Prepare and approve a human } \\
\text { resource development strategy } \\
\text { (medium term), including } \\
\text { plans for staff recruitment } \\
\text { and retention, staff training } \\
\text { and development, and salary } \\
\text { increase projection. }\end{array}$ & $\begin{array}{l}\text { Accomplished, along with a } \\
\text { restructured organogram and } \\
\text { rationalized staff, prioritizing } \\
\text { senior technical and managerial } \\
\text { recruitment. }\end{array}$ \\
\hline
\end{tabular}




\begin{tabular}{|c|c|c|}
\hline Area for Reform & Policy Mandate & Notes \\
\hline \multirow[t]{6}{*}{$\begin{array}{l}\text { Dhaka Water Supply } \\
\text { and Sewerage Authority } \\
\text { (DWASA) } \\
\text { Strengthen DWASA } \\
\text { governance, organizational } \\
\text { structure, financial } \\
\text { management capacity }\end{array}$} & $\begin{array}{l}\text { POLICY CONDITIONS } 7 \\
\text { AND } 8 \\
\text { Define responsibilities between } \\
\text { the board and the managing } \\
\text { director, particularly for } \\
\text { day-to-day management of } \\
\text { DWASA. }\end{array}$ & $\begin{array}{l}\text { Accomplished as a result } \\
\text { of the overall sustained } \\
\text { professionalization of DWASA's } \\
\text { operational environment, } \\
\text { marked by strong managing } \\
\text { directors, stable tenures, } \\
\text { new financial and service } \\
\text { regulations, and more effective } \\
\text { implementation of the WASA } \\
\text { Act, 1996, which clearly defines } \\
\text { roles and responsibilities. }\end{array}$ \\
\hline & $\begin{array}{l}\text { POLICY CONDITION } 9 \\
\text { Five-year business plan and } \\
\text { operational manual for DWASA } \\
\text { (2009-2013) approved by the } \\
\text { board and endorsed by LGD. }\end{array}$ & $\begin{array}{l}\text { Incorporated vision and } \\
\text { mission statements, a } \\
\text { customer charter, financial and } \\
\text { investment plan, performance } \\
\text { targets, and a tariff plan, which } \\
\text { the LGD has approved. }\end{array}$ \\
\hline & $\begin{array}{l}\text { POLICY CONDITIONS } 10 \\
\text { AND } 14 \\
\text { Project and plan for a tariff } \\
\text { adjustment every } 5 \text { years. }\end{array}$ & $\begin{array}{l}\text { DWASA may raise tariffs } 5 \% \\
\text { annually ( } 10 \% \text { with government } \\
\text { approval) but current levels } \\
\text { already cover recurrent } \\
\text { costs (actual O\&M costs and } \\
\text { inflation) and depreciation, and } \\
\text { interest, resulting in a positive } \\
\text { net income for consecutive } \\
\text { years. }\end{array}$ \\
\hline & $\begin{array}{l}\text { POLICY CONDITION } 11 \\
\text { Anticorruption ethics } \\
\text { committee established and } \\
\text { sufficiently staffed, reporting } \\
\text { directly to the managing } \\
\text { director with the mandate to } \\
\text { investigate any corruption } \\
\text { allegation within DWASA. }\end{array}$ & $\begin{array}{l}\text { Seven-member committee } \\
\text { established, chaired by the } \\
\text { deputy managing director, } \\
\text { meeting monthly, and also } \\
\text { mandated to build honesty, } \\
\text { integrity, and mass awareness } \\
\text { among employees to prevent } \\
\text { corruption and malpractice. }\end{array}$ \\
\hline & $\begin{array}{l}\text { POLICY CONDITION } 12 \\
\text { Improved mechanism to } \\
\text { redress consumer grievances. }\end{array}$ & $\begin{array}{l}\text { Help desk established with } \\
\text { personnel, computers, and } \\
\text { other resources to address wide } \\
\text { range of consumer concerns } \\
\text { and requests. }\end{array}$ \\
\hline & $\begin{array}{l}\text { POLICY CONDITION } 13 \\
\text { Starting from fiscal year 2010, } \\
\text { publish on the DWASA website } \\
\text { and make available to the } \\
\text { public annually a full financial } \\
\text { statement and audit report with } \\
\text { proper audit opinion. }\end{array}$ & $\begin{array}{l}\text { Audit backlog cleared and } \\
\text { reports uploaded; no audits are } \\
\text { pending; as part of the 5-year } \\
\text { business plan (Policy Condition } \\
\text { 9), computerized accounting } \\
\text { and financial management } \\
\text { systems as well as a consumer } \\
\text { database were made operational } \\
\text { in 2010, and resulted in more } \\
\text { efficient billing and collection, } \\
\text { leading to improved financial } \\
\text { management. }\end{array}$ \\
\hline
\end{tabular}




\section{Turning Points}

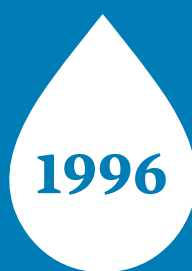

Dhaka Water Supply

and Sewerage

Authority Act, reorganizing DWASA activities, passed by Parliament

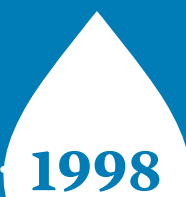

National Policy for Safe Water Supply and Sanitation passed by Parliament

\section{4}

Water Supply and Sanitation Sector

Development Framework and National Policy for Arsenic Mitigation passed by Parliament

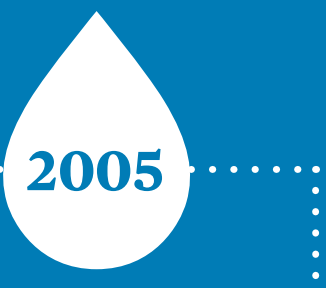

National Poverty Reduction Strategy, emphasizing need for safe water supply and appropriate sanitation, : drafted

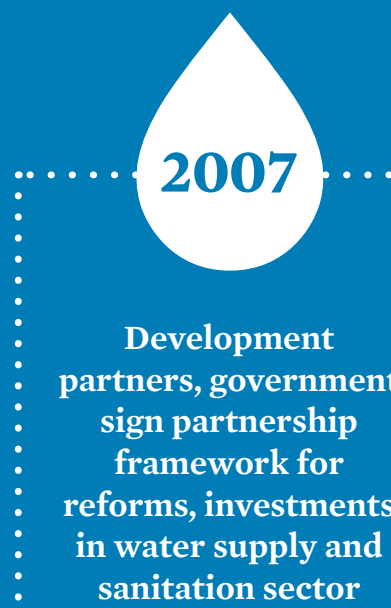

Government gives DWASA

legal authority to connect

slums, and to bill and

collect for water supply to slum areas

\section{6}

Manikdi pilot demonstrates effectiveness of district metered area approach, viability of connecting slums

\section{6}

Sector Development

Program drawn up by the government for the water and sanitation sector

\section{8}

ADB-financed Dhaka Water Supply Sector Development Program begins implementation

\section{9}

Dhaka gripped by acute water shortage

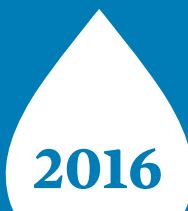

2010

DWASA-initiated Turnaround Program 2010-2014 launched
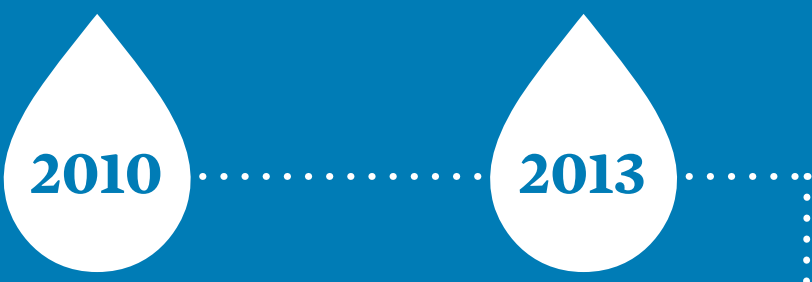

Dhaka

Environmentally Sustainable Water Supply Project approved by ADB

\section{6}

ADB-financed Dhaka Water Supply Sector Development Program completed
Dhaka Water Supply

Network Improvement

Project approved by ADB

-1)

ADB = Asian Development Bank 


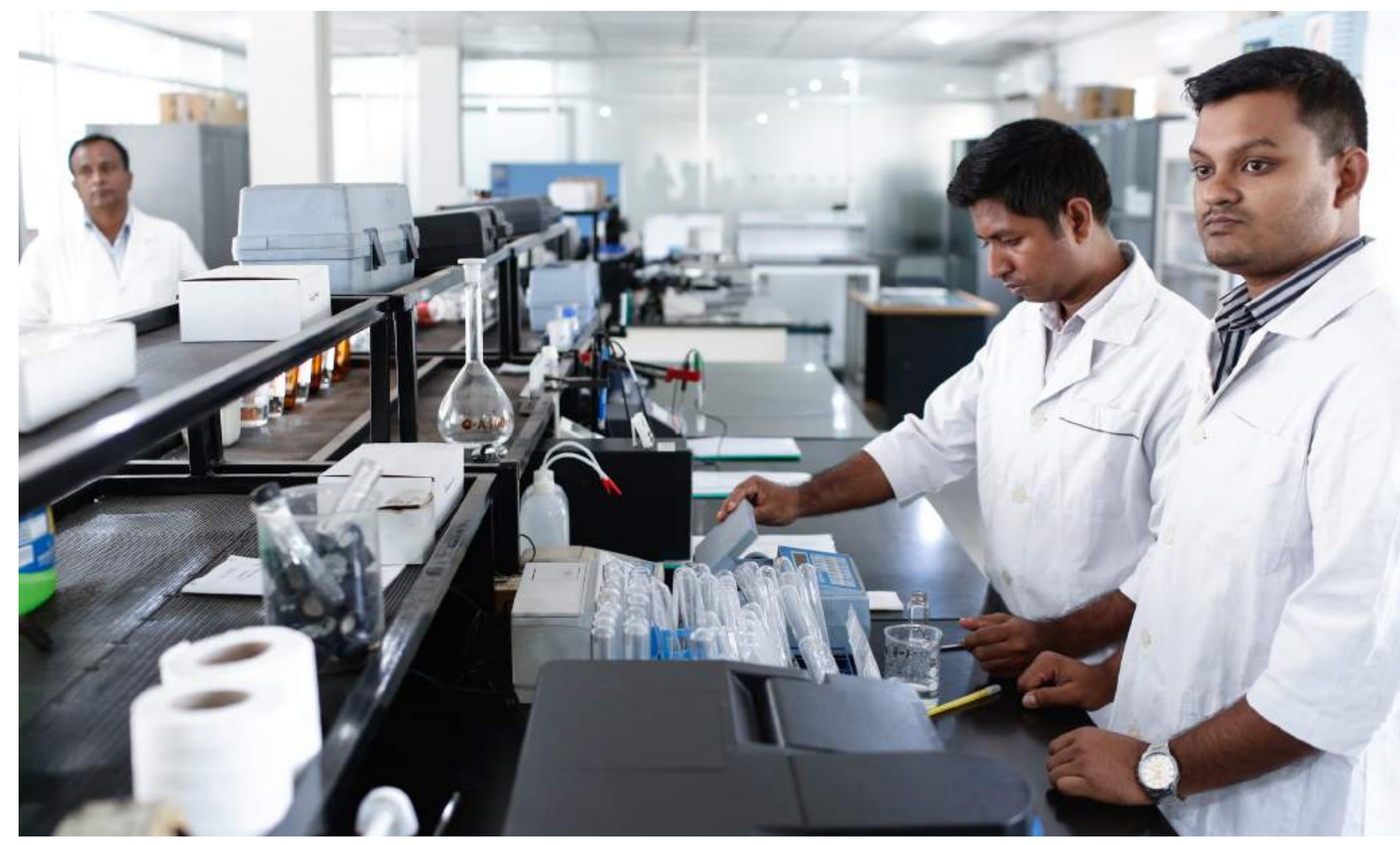

\section{SYSTEM}

\section{TURNAROUND}

\section{How DWASA Used Scale to Deliver on Promises, Expand Services to the Poor}

Even as the government and DWASA were striving to comply with the mandatory policy actions, the infrastructure investment through actual physical works could begin. The project loan (for infrastructure investments) covered three major project components: improving and expanding the distribution system through a DMA; strengthening the DWASA organization and improving its institutional capacity; and controlling water waste and raising public awareness of water conservation. Most of the program was heavily centered on reforms and technical assistance, yet it was DWASA's approach to the physical works that produced the most coveted gains for the utility.

The investments in the physical system were aimed at expanding and improving the supply of water to 8 million people in Dhaka. At least $15 \%$ of the additional supply resulting from the project was to go to low-income communities through standpipes and communal taps. 
hydraulic zones and allow supply and consumption to be measured at both ends; and

- regularly measure NRW and keep it below $15 \%$ in each DMA.

To make construction less of a headache for drivers and residents in the city, DWASA pioneered the use of trenchless technology for laying pipes.

Horizontal directional drilling (HDD) machines, a type of trenchless technology most suitable for the small-diameter water supply pipes commonly used by utilities, did away with the need for expensive relocation (compensation) and reconstruction along sidewalks and easements where businesses and residences had encroached.
To improve water quality, chlorination facilities were built at all supply points, including groundwater pumping stations. Water quality would be monitored through a two-tier system at an upgraded central laboratory. "Our facility before the project was not like this-tiled, and with lighting and temperature controls," recalls Md. Alamgir Hossain, deputy chief microbiologist and head of the microbiology and chemical division at the DWASA Central Laboratory. "Now it is a controlled environment, and this is very important. We are able to test and justify our results much better."

Tahmina Begum, a chemist at the same laboratory, also remembers life at the laboratory before the project. "We would visit other labs and they had all this equipment (for
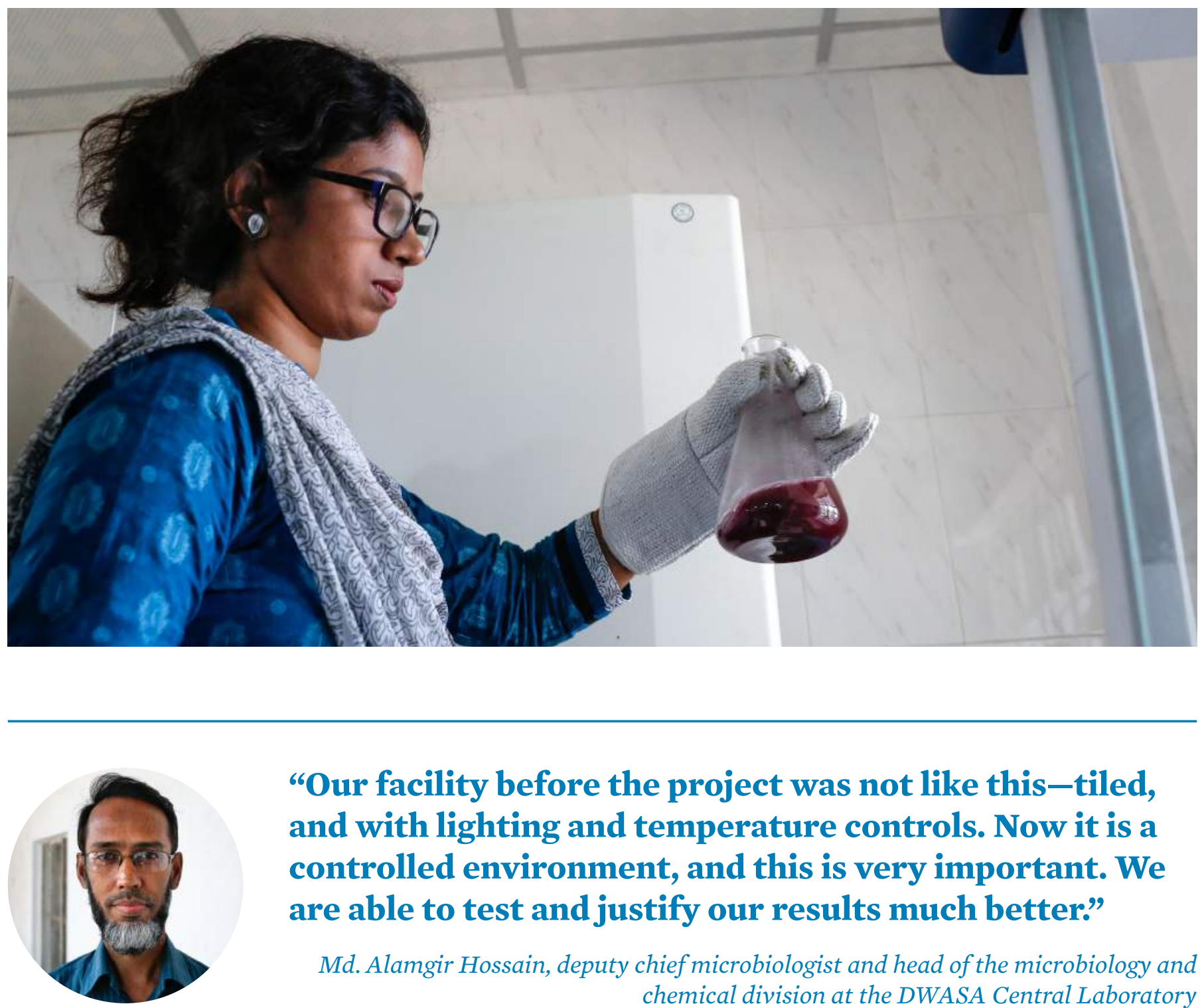

\section{"Our facility before the project was not like this-tiled, and with lighting and temperature controls. Now it is a controlled environment, and this is very important. We are able to test and justify our results much better."}

Md. Alamgir Hossain, deputy chief microbiologist and head of the microbiology and chemical division at the DWASA Central Laboratory 
high-quality water testing) that we did not have before the project," she said. "But now we do, and we're very proud of this."

DWASA and ADB had hoped to improve water services for about 8 million people in Dhaka through the project, and to serve the water needs of low-income, unconnected communities with at least $15 \%$ of the additional supply (see table below). The DMA approach delivered quicker results for customers, and made it easier for the utility to revamp the system. DMAs are permanent systems, which make for better day-to-day operation and management.

\section{District Metered Areas: The Momentum for DWASA's Turnaround}

The zonal approach simplifies complex urban water systems and helps utilities solve system issues that go with old, under-invested, and chronically mismanaged networks like Dhaka's. When DWASA began using the zonal approach, the NRW rate was more than $40 \%$ (or possibly even $50 \%$; the lack of meters precluded an accurate assessment of NRW). Leaks went undetected and undetectable, and the rampant use of suction pumps in legal as well as illegal connections left the system devoid of pressure.

ADB approved a separate technical assistance grant for a pilot project that would test the DMA approach, along with the implementation of new billing and collection systems, in Manikdi (see "Pilot Project Features" on next page). The area was losing about $58 \%$ of its water to leakage and theft. The pilot project would install 215 connections and rehabilitate the network according to the DMA approach.

\section{DWASA's Planned Performance Improvements}

\begin{tabular}{|l|c|c|c|}
$\begin{array}{l}\text { Key Performance } \\
\text { Indicator }\end{array}$ & Benchmark Standard & 2008 Performance & $\mathbf{2 0 1 5}$ Performance \\
\hline $\begin{array}{l}\text { Percentage of all users } \\
\text { billed }\end{array}$ & 99.50 & 93.00 & 99.00 \\
\hline Percentage of bills collected & 95.00 & 64.50 & 97.50 \\
\hline Receivable turnover ratio & 3.00 & 14.58 & 5.46 \\
\hline $\begin{array}{l}\text { Number of utility staff per } \\
\text { 1,000 connections }\end{array}$ & 12.00 & 16.20 & 9.16 \\
\hline Operating ratio $^{\mathrm{b}}$ & 0.65 & 0.90 & 0.66 \\
\hline
\end{tabular}

DWASA = Dhaka Water Supply and Sewerage Authority

a Number of days it takes to convert accounts receivable into cash. The unit used is days. Generally, the lower the ratio, the better.

b Ratio of operational expenditure to operational revenue. A ratio below 1.0 indicates that operating revenue from water tariffs exceeds operating expense. Generally, the lower the ratio, the better.

Source: DWASA.

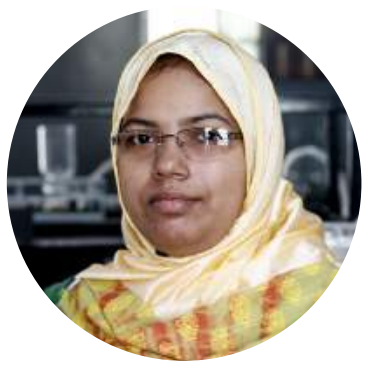

"We would visit other labs and they had all this equipment (for high-quality water testing) that we did not have before the project. But now we do, and we're very proud of this." 
variety of factors could produce unprecedented results. The pilot project would address the following key issues: accuracy of records; quality and types of materials (pipes and joints) used; workmanship traditions; extent of unregistered connections; operation and maintenance (O\&M) quality; water demand analysis and expectations; and categories of produced water (water leaked from the network before it can reach consumers, classified as physical losses; water that reaches the consumer but is unbilled, or administrative losses; water wasted by consumers; and water serving consumer demand).

The pilot study (from March 2006 to December 2007) covered 440 service connections in Manikdi. It confirmed that the high technical losses were due to bad service connectors and clamps, poor-quality pipe joints, spaghetti connections using poor-quality pipe coils, invisible leaks in most pipes and fittings, the inclusion of several unregistered connections under a single account, and bypass line consumption. Appropriate interventions addressing these issues brought down the physical losses from 53\% in March 2006 to $14 \%$ in January 2007 , besides increasing water pressure and improving meters and meter reading in the pilot area. The length of distribution network pipes also increased from 2.5 kilometers $(\mathrm{km})$ to $4.6 \mathrm{~km}$, spaghetti connections were reduced from 418 to zero, and average hours of supply in the pilot area rose from 4.8 hours to 24 hours. The Manikdi pilot project collected essential data for the design of the project, including actual household demand for water, tariff collection challenges and needed improvements, technical options for leak management, and social mobilization strategies.

The Manikdi pilot project was a success.

"We killed two birds with one stone," DWASA's Taqsem says. "We tested the DMA approach and proved that it could be applied to low-income communities to make systems financially viable."

\section{Pilot Project Features}

- Rate of nonrevenue water at the start of the pilot project: $>50 \%$

- Technical assistance project initiated with Asian Development Bank assistance

- Network rehabilitated with high-density polyethylene (HDPE) pipes

- Water meters installed in homes of all consumers

- Rate of nonrevenue water after the pilot project: $8 \%$

- Billing rate after the pilot project: $100 \%$

- Collection rate after the pilot project: nearly $100 \%$

"Success meant there was no going back," ADB's Manoj Sharma adds. "The government was genuinely convinced.”

Scaling up the DMA approach involved breaking down DWASA's large, sprawling network into small zones, or DMAs, each one hydraulically isolated, independent of the other areas in water pressure, quantity, and quality. Each area has intake and exit meters to measure supply within the area. Each consumer has a functional meter to determine consumption.

DWASA used the following five factors to determine the four zones (out of the city's six zones) to include in the ADB-financed project:

\section{- Where infrastructure baselines were} higher. DWASA has progressively rehabilitated and replaced most of the old pipes dating from the 19th century in two of the zones under various government-funded projects. Further, despite their dense populations, the two zones have low to moderate pressure in the supply lines, resulting in less leakage than in the remaining zones. 
- Where new water supplies were scheduled. DWASA planned to bring in additional water from two proposed water treatment plants to meet the city's growing demand. The distribution network in the project zones would receive most of the additional water. If these project zones were not rehabilitated, the new water supply would cause more leakage from the system and undermine the impact of the proposed supply augmentation.

- Where rate of illegal connections was highest. One of the four zones had the most "spaghetti connections"-water illegally tapped, usually through rubber hoses that look like boiled spaghetti. These spaghetti connections leaked profusely, but the other project zones reportedly accounted for even more physical losses.

\section{- Where the population had already} reached its saturation point. Population growth in two of the zones seemed to have reached saturation level, while the population in the remaining four zones continued to increase rapidly.

\section{- Where the beneficiary ratio of poor} households to new connections was highest. The DFID was assisting DWASA with improvements in many slum and low-income areas in two of the project zones, and the assistance would benefit the largest number of the poor and slum dwellers.

The DMA approach facilitates water balance analysis, which is the regular assessment of water supply and consumption and water losses. The challenge is sustaining the regularity of the analysis. DWASA now does it monthly but plans to emulate the good practice set by other developed utilities that do real-time water balance analysis online for each DMA, and are thus able to measure NRW in the DMA at any given moment.

"Before, we had one system," Taqsem notes. "Now, we have 145 clusters, or DMAs. It's an in-and-out system. We know exactly what is going into an area and what's going out. It's all measured."

A DMA may source its supply from groundwater (through a permeable treatment wall) or surface water, or both. DMA 501 in Dhaka has four water sources: groundwater, surface water, conjunctively managed water systems, and, if necessary, water from an adjacent DMA (see "The Basics of the District Metered Area (DMA) Approach on page 26).

A well-managed and highly functional DMA also helps make the utility more resilient to climate change and better able to adapt to climate change threats and impact. Climate change is likely to heighten the threats to Dhaka's already vulnerable water security. The decline in water availability, due to altered precipitation patterns and increased evapotranspiration caused by higher temperatures, and the rising incidence of water pollution from flooding are major climate risks. A rise in the number of weather events that could disrupt water supply service is a secondary risk, along with rising sea levels, which could increase the salinity of both groundwater and surface water. The use of the DMA-based approach reinforces the city's water security by making more water available through efficient water management systems.

\section{"Before, we had one system. Now, we have 145 clusters, or DMAs. It's an in-and-out system. We know exactly what is going into an area and what's going out. It's all measured."}




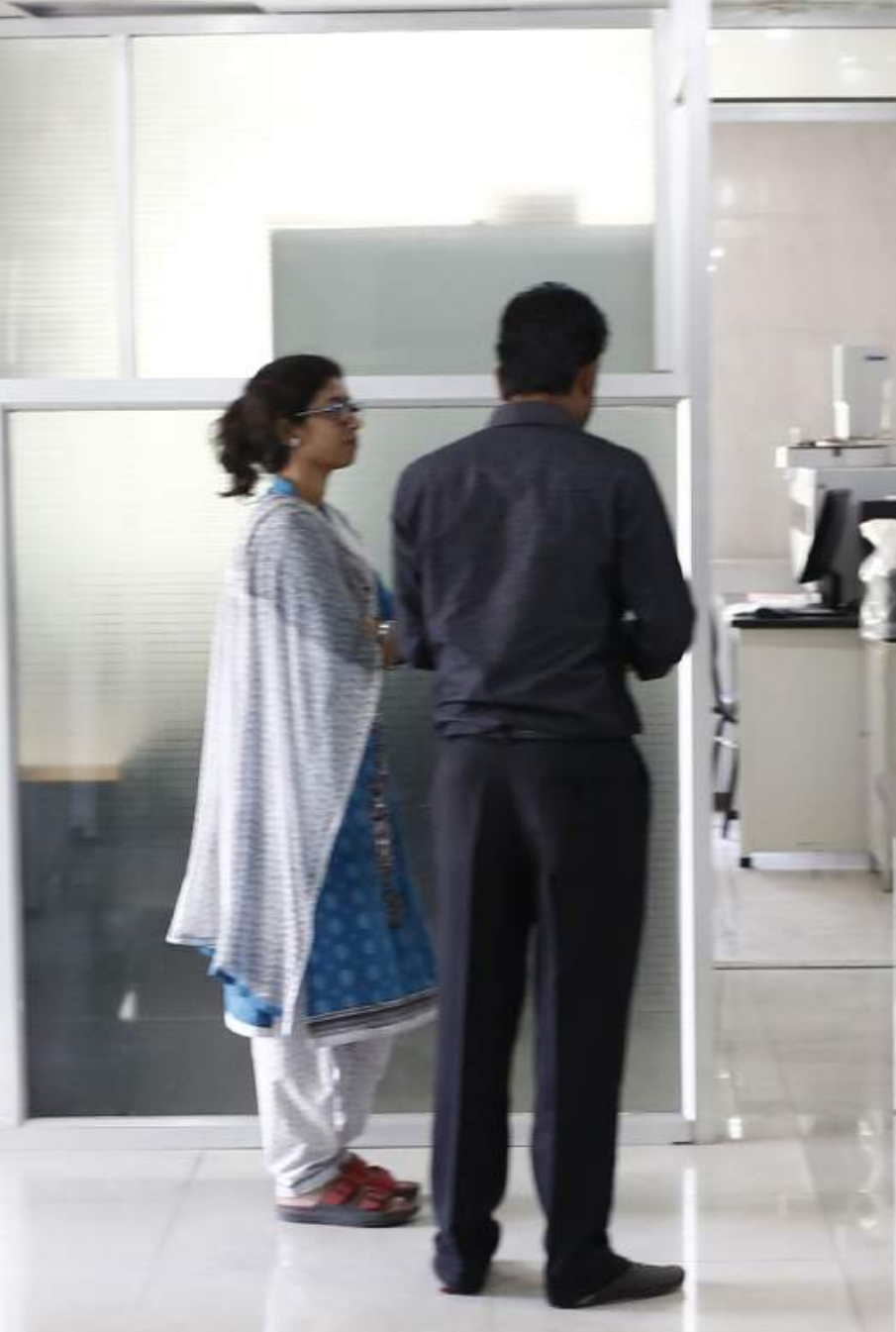

"We are still struggling. But we're also making progress and we are now at least a standard lab. My dream is for this lab to be a reference labwith accreditations." 


\section{The Basics of the District Metered Area (DMA) Approach}

\section{Benefits}

- Up-to-date water balance information

- Minimized nonrevenue water

- Easier detection of leaks and illegal connections

- Energy-efficient system

- Pressurized system

- Improved water quality

- More satisfied customers

- A profitable organization

\section{Primary Criteria}

- Hydraulic isolation

- DMAs that are "neither too big nor too small" in size

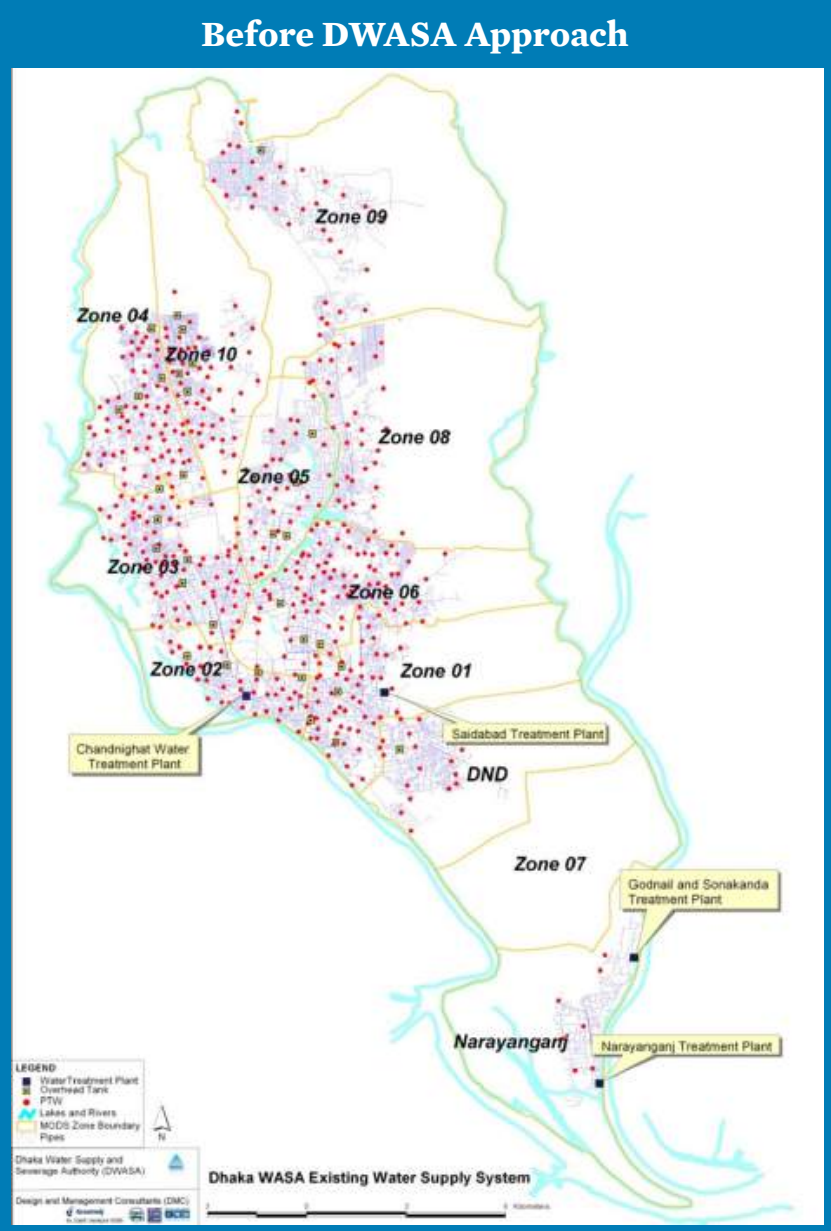

- At least one reliable water source

- At least one external connection for emergencies

- All connections and sources metered

\section{Secondary Criteria}

- Well-defined roads

- Administrative boundaries

- Land use and housing pattern

- Future developments

\section{How DWASA Established DMAs}

DWASA took the following general steps to identify the boundaries of DMAs and to carry out the works needed to bring the area under

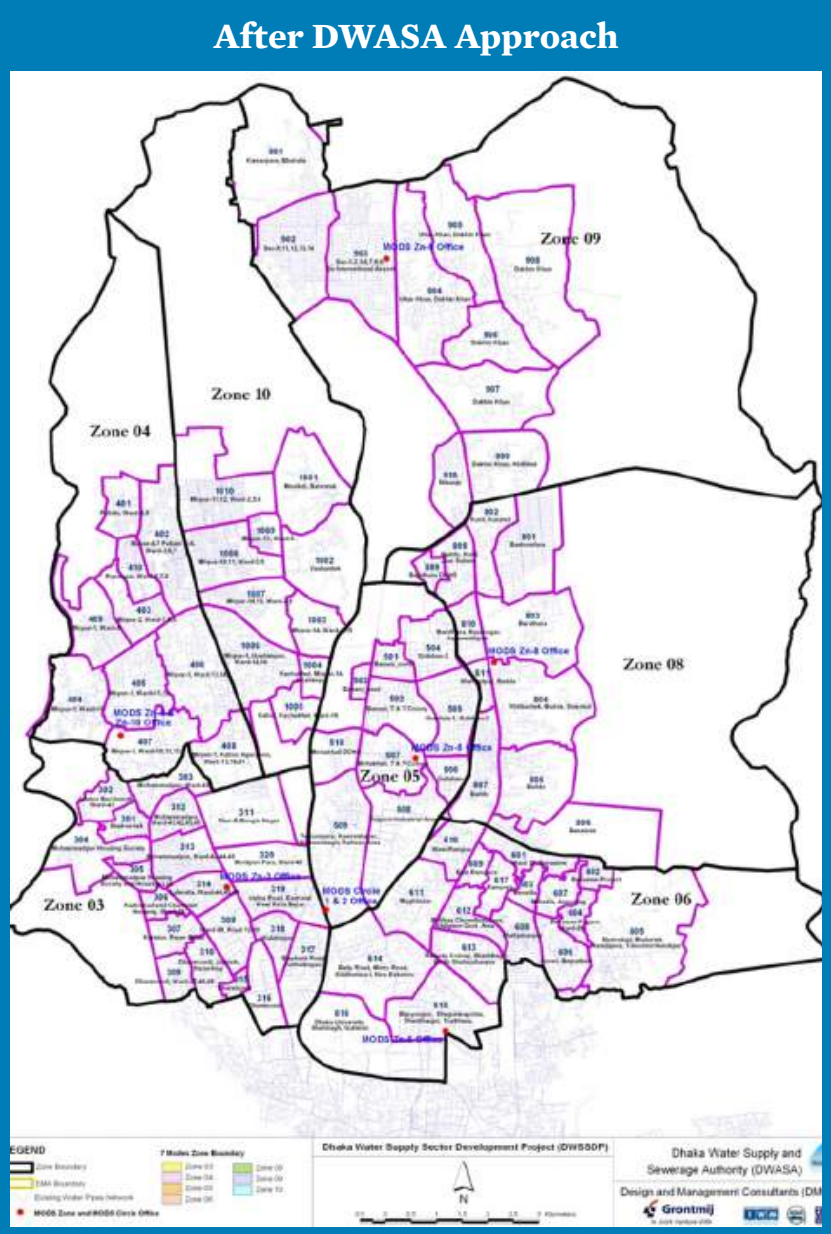


pipe bursting, shotcreting, gunite spraying, cured-in-place pipe (CIPP) works, grout-inplace pipe works, mechanical spot repair, and other methods. ${ }^{6}$ Mechanical spot repair is applied where damaged pipelines require the reinstatement of structural integrity. Sliplining, CIPP, and thermoformed pipe lining involve pulling or inverting a new liner into an existing pipe, then applying heat or pressure, or both, to force the liner to expand to fill the pipe. CIPP technologies combine a carrier (felt or fiberglass) impregnated with heat, ultraviolet light, or ambient curable resin to form a "pipe within a pipe." Pipe bursting fractures a pipe from the inside and forces the fragments outward while a new pipe is drawn in to replace the old. The other methods are primarily for fixing spot leaks. Trenchless rehabilitation methods are generally more cost effective than traditional excavation and replacement methods.

DWASA and ADB pioneered the use of trenchless technology to reduce the project's environmental and resettlement costs, besides minimizing the impact of construction on communities. About $90 \%$ of all pipes were laid through horizontal directional drilling, and the open-cut method was used only in the most congested streets (about 10\% of the total).

DMA 1006 required the use of the open-cut method. Among DWASA engineers, it was "the most difficult area to connect and implement the pipeline works because of the density and narrow roads," recalls Md. Arifuzzaman, sub-assistant DWASA engineer. "We had to change our methods and schedules. Instead of using trenchless technology, as we had planned to do, we had to use the open-cut method. It took more time." Contractors announced their work schedules ahead of time, and explained that water service would not be interrupted but that a water tank would be on standby.

\author{
"If we cut off their water for \\ even an hour, they would \\ make us stop working. We had \\ to explain to them that the \\ smaller pipes were creating \\ more pressure. We had to give \\ them our word that if they had \\ a problem, they could come \\ directly to us."
}

Shahid Uddin, project director and chief engineer, DWASA

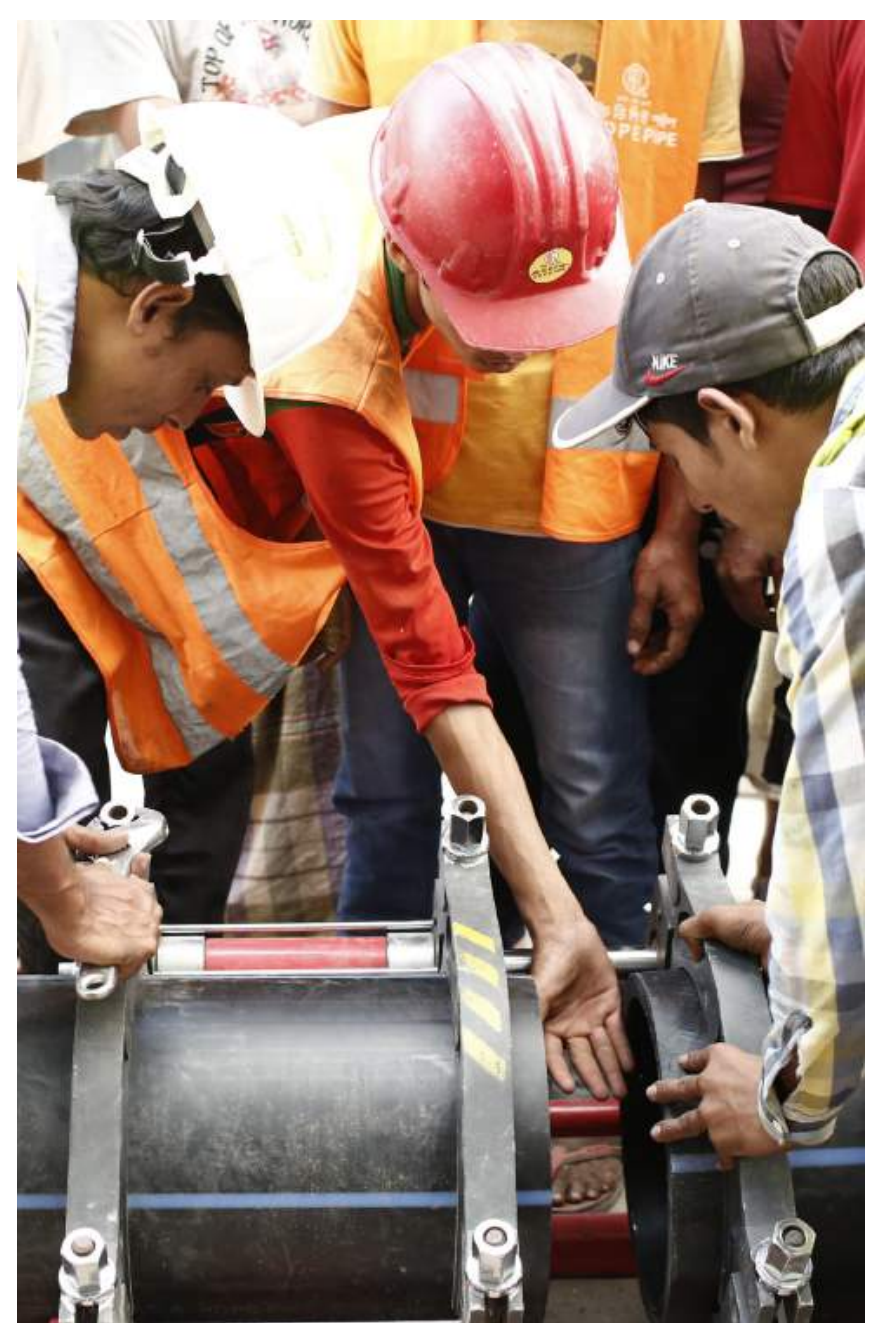

This discussion of trenchless methods of rehabilitating underground pipes is taken from https://en.wikipedia.org/wiki/Trenchless_technology, which is based on Jadranka Simicevic and Raymond L. Sterling. 2001. Guidelines for Pipe Bursting. TTC Technical Report \#2001.02. US Army Corps of Engineers Engineering Research and Development Center. March. 


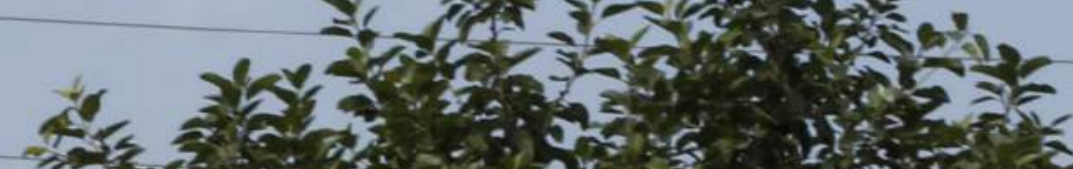

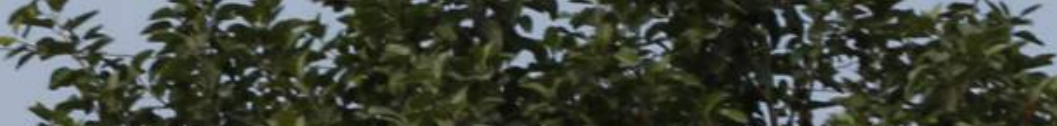

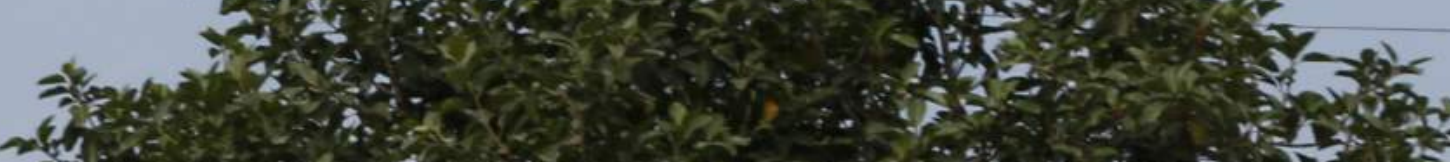

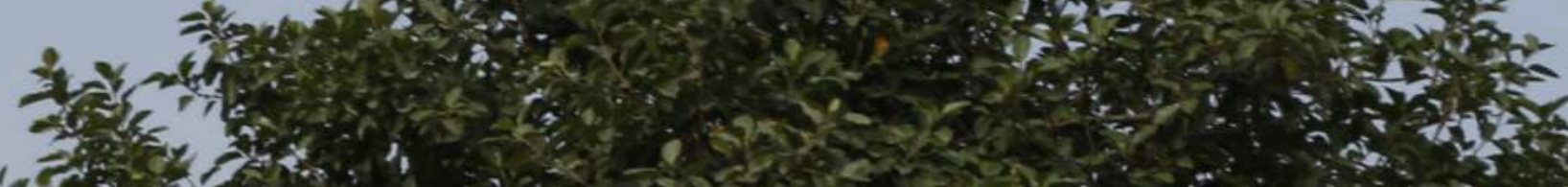

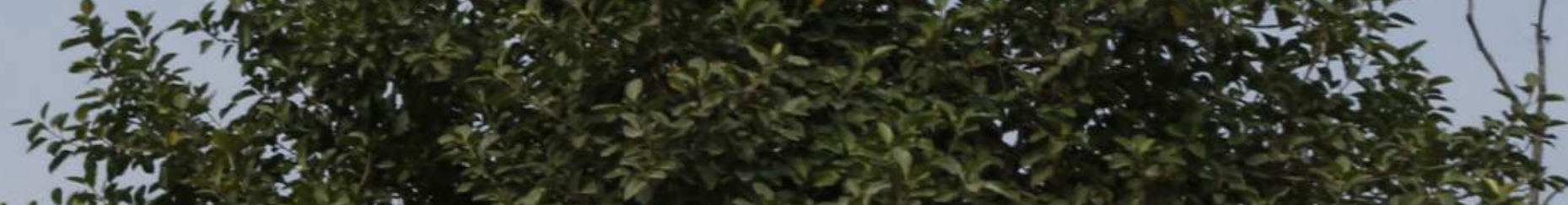

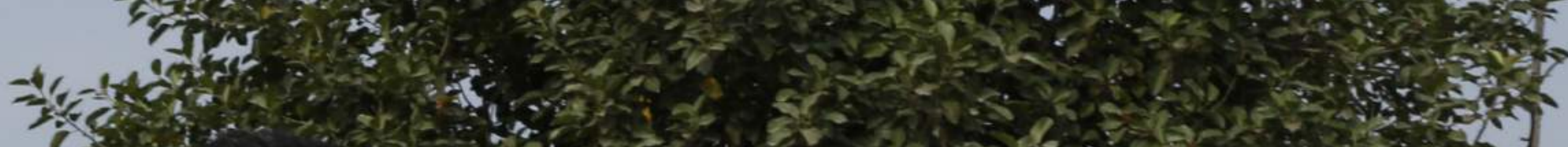

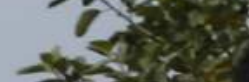
$-1020$ oritions

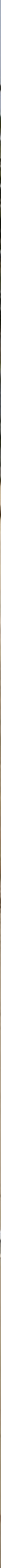

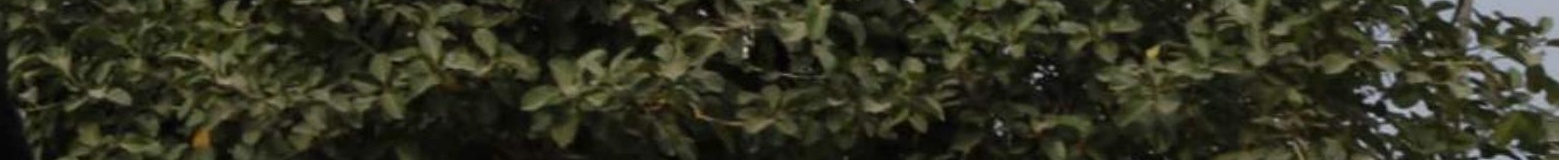


Connecting the Poor: A Game-Changer for DWASA

ADB Principal Urban Development Specialist Manoj Sharma remembers the first time he saw the map of Dhaka city and the areas that DWASA planned to include in the project. Large areas of the map were blacked out. Sharma asked his DWASA counterparts about them. "They said, 'Oh, those are slums. We can't include them." Sharma was shocked. Those neighborhoods made up a large part of Dhaka and DWASA's service area. He wondered, "If we don't connect slums, how will the ADB project help the poor?"
Estimates of Dhaka's slum population vary, but ADB puts it at about 3 million-30\% of Dhaka's total population. The government's census bureau defines a slum as a "cluster of compact settlements of five or more households which generally grow very unsystematically and haphazardly in an unhealthy condition and atmosphere on government and private vacant land" (see box below with the descriptive criteria commonly used to define slums). Slum households have had no choice but to buy low-quality water from private vendors at exorbitant ratesas much as $15-20$ times the DWASA rate, according to some residents.

\section{Common Descriptive Criteria for Defining Slums}

- Predominantly very poor housing

- Very high housing density

- Very cheap and low-quality housing materials

- Poor or no sewerage and drainage

- Inadequate, unhealthy drinking water supply

- Insufficient or no street lighting

- Few or no paved streets

- Inhabited by poor, uneducated people living below the poverty line

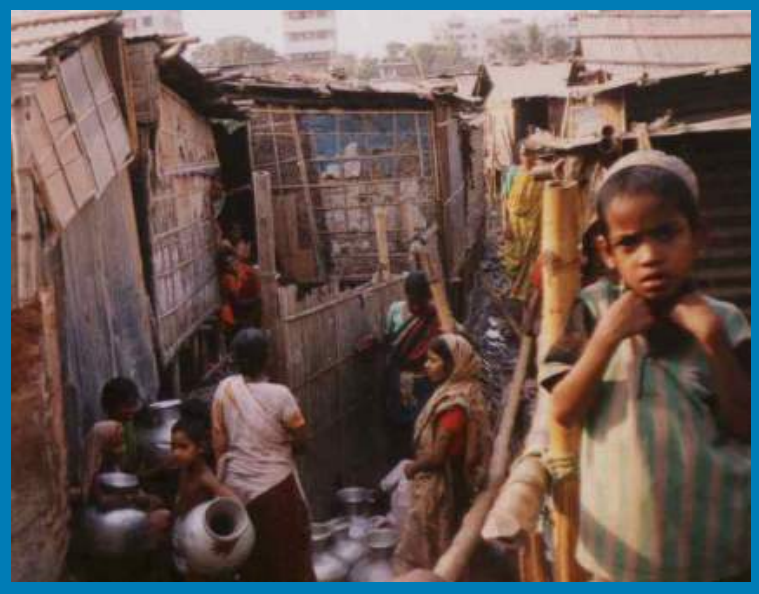

Source: Iffat Huque. n.d. Urban Slum Mapping in Bangladesh. Dhaka: Center for Environmental and Geographic Information Services.

\section{“They said, 'Oh, those are slums. We can't include them.' [But] if we don't connect slums, how will the ADB project help the poor?"}




\section{Uphill Battle to Connect the Poor}

Sharma looks back on the uphill battle waged by his team and DWASA's Taqsem to extend networks to the poor. "Engineers were not interested," Sharma recalls. "We started a policy dialogue with the government, and even visited the slums with them, but after the first project design mission, the secretary at that time said, 'No. We can't do this.”'

Taqsem remembers his institutional challenge thus: "There was a big argument over whether the low-income communities should be connected. Some said that the government is not legally obligated to connect those communities. They don't have legal housing. But connecting them to safe drinking water does not legalize their housing. Water is their right. It is our responsibility. Another point raised had to do with investments-that if we invest in connecting illegal houses and those living there are evicted, the investment will be a loss. I can live with the loss. Water is their right."

Several mind-set issues within DWASA have also stalled water connections for the poor. Those counterproductive ideas have been noted by ADB and DWASA leadership in various public forums.

\section{"If illegal connections are not dealt with, illegal pumping and pilferage will continue, affecting the pressure in} other areas of the system and hurting paying customers. You should just turn those water thieves into regular customers."

Zahir Uddin Ahmad, team leader for water resources management at ADB's resident mission in Dhaka

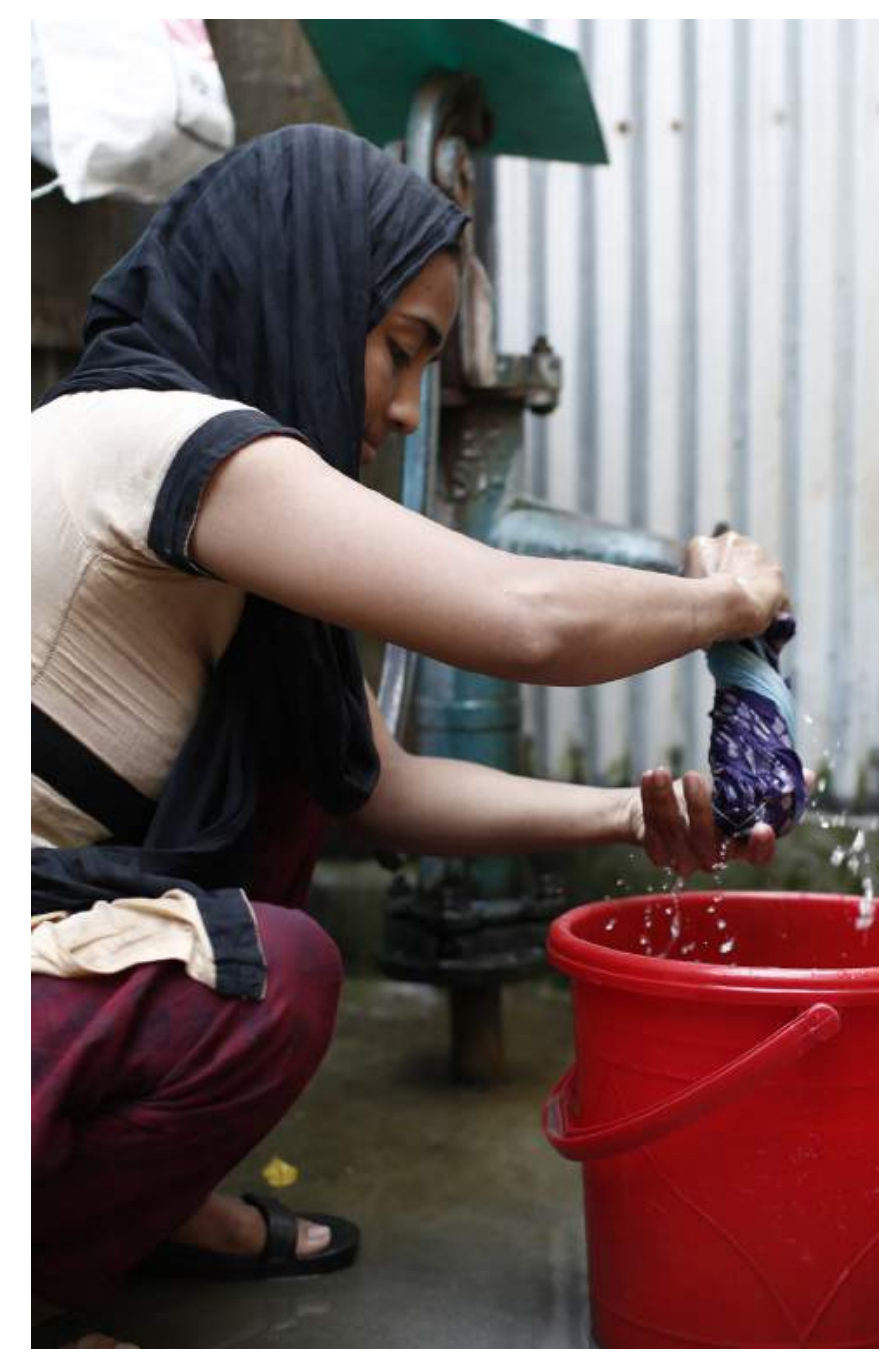

- "Connecting slum dwellers is illegal." Individual household connections are illegal but connections for community-based organizations are allowed under a government policy adopted in 2007.

- "Good service delivery in slums will encourage further encroachment on government, private lands." While this is a valid concern, complementary policies and market support for low-income housing options would keep the poor from solving the dearth of low-income housing through encroachment. Slum housing is not free or cheap; this indicates that the poor are an untapped market for low-income housing. Social services in slum areas, provided together with savings programs, will enable poor households to save income that could be invested in affordable, legal housing. The lack of such housing requires direct government intervention. 
- "Slum dwellers cannot afford connection costs and tariffs." The project proved that the poor can afford legal access to water services when they pool their resources to pay for shared sources and community-managed schemes. Other utilities have also used cross-subsidies and block tariffs (based on ability to pay and consumption rates) to waive connection fees for low-income households.

- "The poor do not need individual connections." In addressing water poverty, community-managed, shared connections to clean, reliable, legal water supply are a step in the right direction but are not the optimal solution for maximum health or convenience benefits. If physical conditions are conducive to individual connections, laws that prohibit such connections deny the unserved their human right and are discriminatory.

- "The poor will not pay their bills." Pilot projects and utilities have disproved this notion. Access is highly valued by the poor, who are among the best-paying customers with the lowest default rate.

Not connecting illegal housing settlements also gives rise to technical issues and financial costs. "If illegal connections are not dealt with, illegal pumping and pilferage of water will continue, affecting the pressure in other areas of the system and hurting paying customers," says Zahir Uddin Ahmad, team leader for water resources management at ADB's resident mission in Dhaka. "You should just turn those water thieves into regular customers."

\section{"Building water storage and treatment plants without the proper distribution network can be like pouring water into a leaking pot. We have to do things differently. Networks- we must make sure they work properly and also benefit the poor."}

Manoj Sharma, principal urban development specialist, $A D B$

\section{Expanding Design to Extend Services to the Poor}

Investments in water supply systems have historically centered on the higher-cost components of infrastructure development. An urban water supply project would typically involve building a reservoir, a water treatment plant, and main transmission lines. Government or utility funding would cover the smaller pipes for the network and the water meters, which tend to bypass poor communities. Some projects may also include the construction of wastewater treatment plants.

"Building water storage and treatment plants without the proper distribution network," says ADB's Sharma, "can be like pouring water into a leaking pot. We have to do things differently.

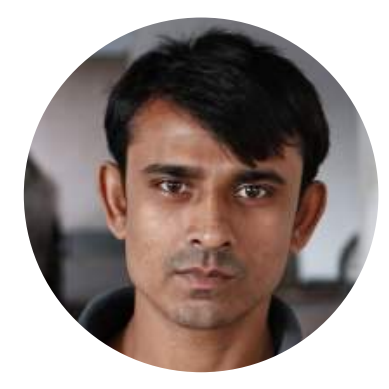

"Water was the biggest issue. There wasn't enough for the residents' daily needs. We had to use two pumps to get water to the top floors. Now we use only one pump and have no water problem." 


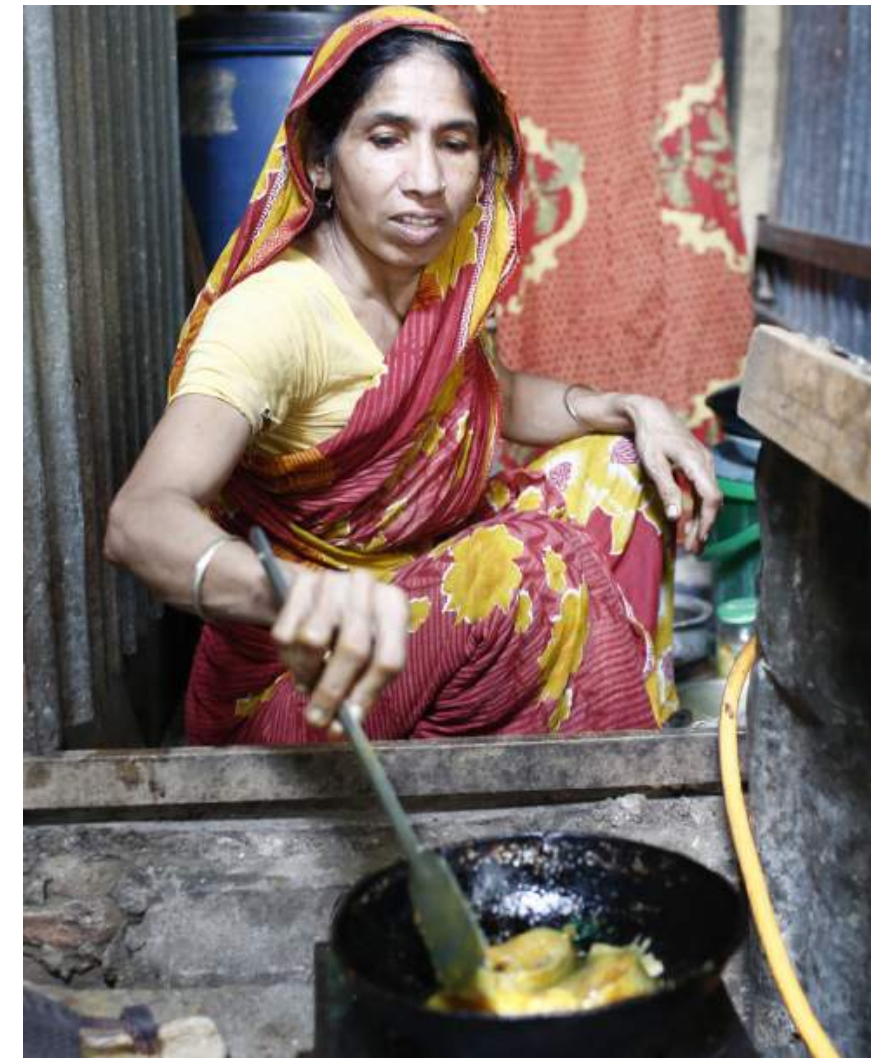

Networks-we must make sure they work properly and also benefit the poor."

\section{Korail and Shattola Slums Are Successfully Connected}

With the DMA approach presenting a viable opportunity to connect the poor, the project design was expanded to include two sprawling slums: Korail and Shattola.

The goal was to provide the registered slum areas with 2,000 communal metered connections, each one serving 15-25 households and contributing evenly to the monthly bill. The shared connections would give access to safe drinking water to as many as 30,000 households in all.

“This project caught us by surprise," admits Shankar Chandra Adhikary, from Dushtha Shasthya Kendra (DSK), an NGO that has worked in the project slum communities for several years. "No other donors except ADB had been willing to demand and get legal connections for these slum communities."

Korail, over 25 years old, is Dhaka's largest slum. Its more than 50,000 households-about 125,000 people-have no legal land ownership or legal access to basic utilities. Before the project, Korail had only 14 legal connections to DWASA and these were controlled by "mustangs" (middlemen), who were also selling water from 65 illegal connections at 15-20 times the DWASA rate. NGOs had likewise been providing tanker services for many years, and possibly had a vested interest in keeping things unchanged.

At ADB's urging, DWASA took direct responsibility for installing new water sources, chlorination units, and connections instead of passing the responsibility to NGOs. The stigma associated with slums-and perhaps the shame of not having given them access to water earlier, plus vested interest in maintaining the status quo-made the DWASA staff largely reluctant to work in those areas at first. NGOs, acting as advocates rather than development contractors, played a vital role in breaking the ice between the utility and the communities. They presented DWASA's plans and organized community-based organizations (CBOs) to mobilize more communities. They also helped the CBOs apply for and obtain connections,

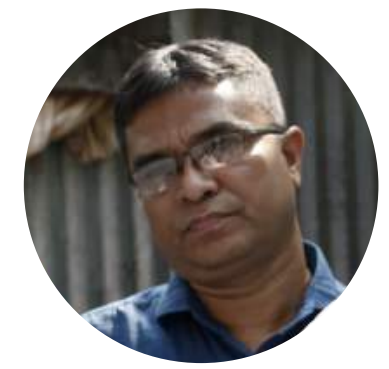

\section{"This project caught us by surprise. No other donors except ADB had been willing to demand and get legal connections for these slum communities."}

Shankar Chandra Adhikary, Dushtha Shasthya Kendra (DSK), an NGO

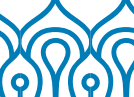

\section{人}

\section{Dushtha Shasthya Kendra (DSK), an NGO}


understand the billing and payment process, and collect from their members.

DSK was one of the NGOs that DWASA contracted to raise community awareness of the project and organize CBOs. DSK leveraged its years of work in Korail to bring together DWASA and CBOs that were already in place. The CBOs were led by volunteer officers, who helped arrange meetings between the communities and DWASA.

\section{Startup Challenges in Low-Income Communities}

DWASA staff, NGO contractors, and CBO officers had to overcome several challenges during project startup in Korail.

"At first, the people did not understand the benefits," notes Abdul Mannan, secretary of one of the CBOs. "They didn't give us space or time or attention. They did not believe we could get water from DWASA. So we told them, 'Just let us do our job and you will see.' We convinced them day by day."
The local water mafia, the mustangs, were the hardest to convince.

"Some people who were making money off the water crisis really disrupted our work at the start," Selina Aktarin, president of Central CBO in Shattola, now reveals. "They tried to discourage us from taking on the project. They even threatened us with guns, but we were steadfast. They demanded things, money, but we gathered support until there were many of us. Then nothing they did could bother us."

Clever as well as practical strategies helped. Aktarin declares, "In the communities, we connected the mustangs first. They felt the benefits right away. Those problems are behind us now."

Aktarin's CBO, like others, also faced resistance from wealthier communities nearby, which refused to grant right-of-way or allow connections. The standoff worsened when neighboring residents stopped Shattola CBO from connecting its drainage project to their main drain. "It took much convincing, but in

"Some people who were making money off the water crisis really disrupted our work at the start. They tried to discourage us from taking on the project. They even threatened us with guns, but we were steadfast. They demanded things, money, but we gathered support until there were many of us. Then nothing they did could bother us." Said Selina Aktarin, president of Central CBO in Shattola
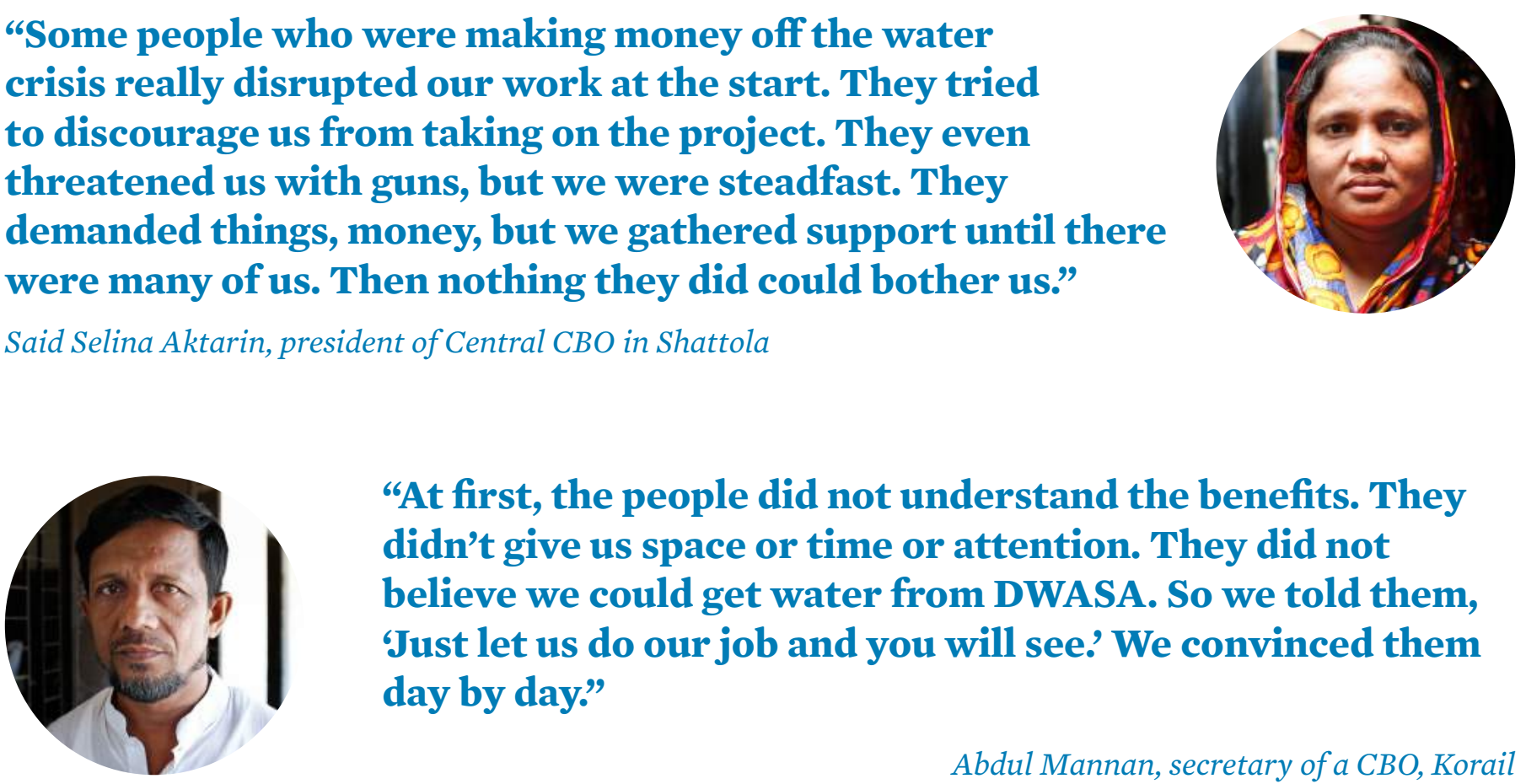
"At first, the people did not understand the benefits. They didn't give us space or time or attention. They did not believe we could get water from DWASA. So we told them, 'Just let us do our job and you will see.' We convinced them day by day." 
the end we prevailed," Aktarin points out.

\section{Success Stories}

Female members and leadership in the CBOs have flourished under the project. "Women are better at convincing than men," notes Aisha Aktar, one of the female leaders. She points out that more women now have an outlet for expressing their needs and meeting their raised expectations. Of the $21 \mathrm{CBO}$ presidents, 17 are women.

The collection rate in Korail and Shattola is one of the highest among Dhaka's DMAs, demonstrating how highly the connections are valued. "Customers are now willing to pay their bills. I no longer hear complaints about the quality of the water or the price," reports Most. Nurunnah, a CBO treasurer in Korail. "From having to pay Tk150 monthly per house for dirty water that was available only once a day or once every 3 days, residents now pay only Tk50 for clean water that is always available.” In 2015, Korail received a citywide award for prompt payment.

DWASA Project Director and Chief Engineer Shahid Uddin speaks candidly about the impact of the project on his professional and personal life. "Before, if you asked me to go to
Korail slum, I would say, 'No, I can't. I'm afraid to go there," he admits. "I knew they didn't have water." Uddin adds, "But now, anyone from DWASA can go to Korail. The people there will keep us safe. They know we mean well." Other DWASA staff say the same thing. They know just what the early CBO champions of the project were up against. "If they had given up and been afraid," DWASA's Wahida Begum says, "their development would have stalled. They wouldn't have all that they have now."

\section{Multiplier Effects}

DWASA staff are witness to the development power of clean, reliable water supply. Once connected, households started investing in their communities, as did local and international NGOs, and have been taking better care of communal areas. "People are improving on what they have begun," Uddin says. "They are washing and doing the laundry more now that water is no longer a concern. They are adding a second, or even a third, story to their homes. They are cleaning up the streets."

Many roads and paths have been paved with cement. More schools have opened in the communities, many with sanitation facilities

\section{"Customers are now willing to pay their bills. I no longer hear complaints about the quality of the water or the price."}
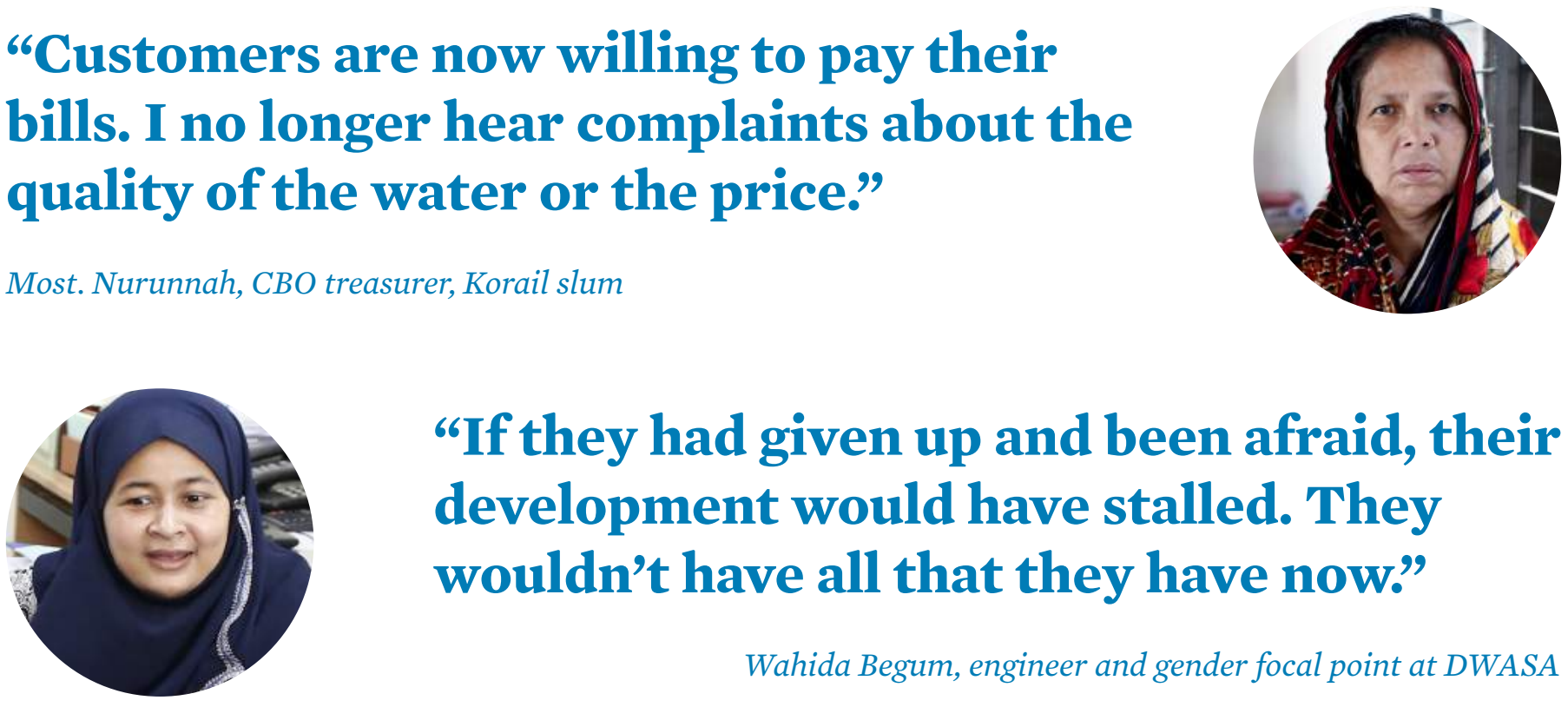

"If they had given up and been afraid, their development would have stalled. They wouldn't have all that they have now." 



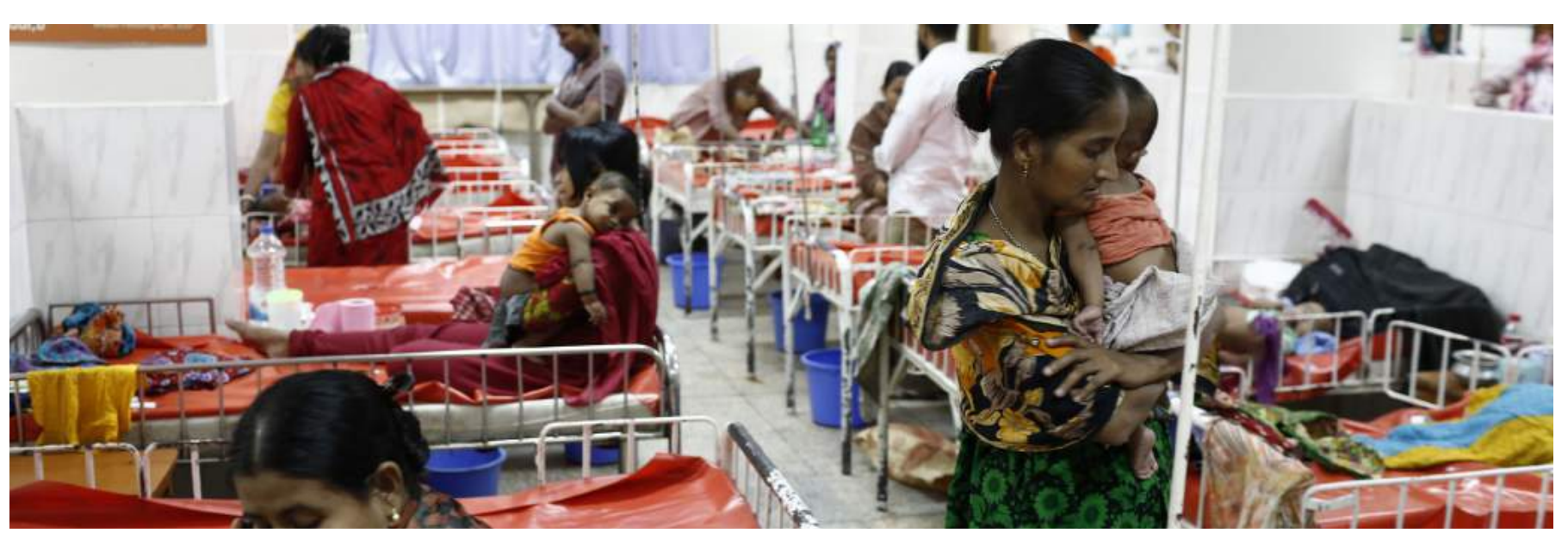

health problems and is likely to receive more education than her mother, who had to leave school after grade 8. "I go to school every day," her daughter, neatly dressed in a fresh uniform, announces proudly. "I want to be a doctor."

Water has also brought better health. When residents half-jokingly talk about the "permanent booking" they used to have at the "cholera hospital," they are referring to the International Centre for Diarrhoeal Disease Research, Bangladesh (ICDDR,B) in Dhaka, where severely malnourished children suffering from cholera-like symptoms are treated, with global funding support. Before the project, the center typically experienced two epidemic scales of cholera each year, in the month before and after the monsoon season.

"In the last couple of years, we have not seen huge peaks in the pre- and post-monsoon months, as we usually did," observes Azharul Islam Khan, chief physician and head of hospitals at ICDDR,B. The falloff, according to Mohammad Ullah, head of nursing at the center, could be due to "better water supply, sanitation, or health education."
But Khan cautions, "There are still problems in end-user quality of water because of the system, and the impact of climate change on epidemics has yet to be felt."

Local community clinics in Korail and Shattola, for their part, are reporting dramatic gains. "Before the water situation in this area improved, we would see 50 patients with cholera or severe dysentery each month," says Md. Moir Hossain Khan, health facilitator at the Marie Stopes-funded community health clinic in Shattola. "Now, only between five and seven come for that. More people know about the need for adequate hygiene and sanitation, more homes have toilets, and there is a toilet block for every 40 people. More people are aware of health issues and their rights, and they want to know how they can help improve their local health systems."

Encouraged by the project's success in slum communities, DWASA looks forward to replicating the DMA approach and legalizing connections in other slum areas of Dhaka, eyeing $100 \%$ coverage by 2017 .

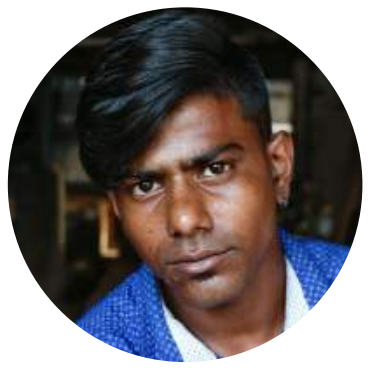
"Before the project, we had water only 12 hours a day and it was dirty. We couldn't sell our ice sometimes because the color of the water was bad. Now we have water 24 hours a day and it's clean. Our sales have increased." 

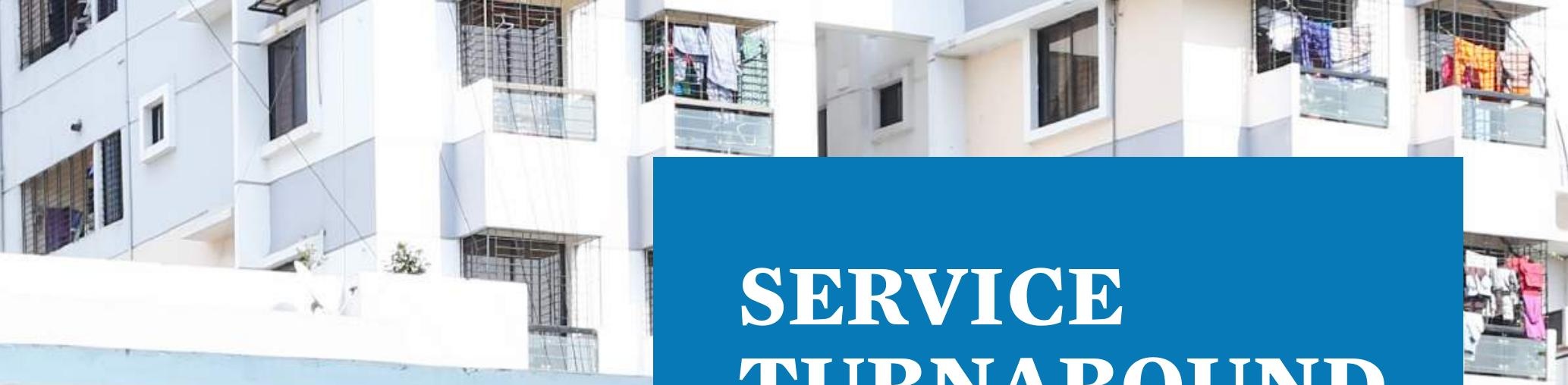

\section{SERVICE TURNAROUND}

\section{DWASA Turns Spotlight on Staff, Customers}

Turning around DWASA for the long term would take more than new pipes and meters and clean water-the tangible stuff of the project. Systems depend on people, and with people come perceptions and practices that either work for the good of the company or do not. DWASA's Taqsem Khan had joined the ADB investment program late, after nearly 3 years of turnover and vacancy had left the managing director's chair cold and the program in trouble because of lengthy delays. But Taqsem had more than just the ADB investment to think about. DWASA's mandate also includes the city's sanitation and drainage systems, which were in even worse condition. He recognized the problems his ADB counterparts had seen-high NRW rates, lack of coverage for the poor, nontransparent business operations, and unskilled laborand designed the program to address those problems. Taqsem was fortunate to have the resources of the $\mathrm{ADB}$ investment to improve the softer, yet no less essential, side of the business. The program was designed and funded to provide DWASA with:

- transparent, sound financial management;

- comprehensive technical, social, and customer training for all staff, as well as plumbers and NGO partners across the city; and

- an extensive awareness campaign, to turn consumers into customers, and users into conservers. 
Now, with Taqsem at the helm, the utility had a champion within the organization who could get the program on track and deliver meaningful, sustainable change. Implementing the activities and tasks in the project would have been pretty straightforward. DWASA had already gone through some of the same reforms earlier. The hard part was getting the reforms to take root. Beyond merely implementing the governance components of the project, Taqsem saw his job as understanding why the system and the staff were in the condition they were in, and how to inspire change, turn drudgery into diligence, and build public esteem for this essential public utility.

Coming from a solid career in change management, Taqsem did what any new chief executive officer of a seriously troubled organization would have done. He assessed DWASA from top to bottom, then drafted a plan to change everything. This "Turnaround Program" was billed at more than $\$ 1$ billion. Taqsem knew the utility was not good for the money-yet. "I wanted surface water, so I needed financing, and for that I had to prove our capacity and convince the banks that we were a good investment and that their money would be repaid," Taqsem points out.

\section{New Vision, Mission}

To build the capacity of the workforce, Taqsem started by casting a new vision for everybody: to be the best public water utility in South Asia. It was a bold vision, one that was probably inconceivable at the time to everyone around him. The accompanying mission hinged on being environmentally friendly, being

\section{"This is South-South} learning at its best."

\author{
Manoj Sharma, principal urban \\ development specialist, $A D B$
}

financially sustainable, and being

pro-people. "Until we have achieved all three, our mission is not done," Taqsem asserts. To be environmentally friendly, Taqsem's Turnaround Program planned a radical shift from indiscriminate groundwater use to surface water supply by 2021 , and from pumping to a completely pressurized system to cut energy consumption. It also envisaged connecting all slums by December 2017.

The drive to be financially sustainable and pro-people or customer oriented, on the other hand, came up against a fundamental problem in the way DWASA was doing business, which Taqsem immediately recognized. "In many government offices, there is this mind-set that we are the masters and the public-the customers-are the servants," he says. "But our salary comes from revenue-customers. So who is the master? The customers are king." In other words, if change was going to be real and lasting this time, this mind-set would have to change. The "customers are king; we are the servants" mantra defining Taqsem's leadership at DWASA is instilled through discussions, meetings, and training (see "Service Minded is People Minded" box on next page).

The ADB investment and partnership agreement with other donors supports all three aspects of the new mission.

\section{Training a Pro-People Workforce}

With project support, DWASA's training program has dramatically improved in scope and intensity. Besides modernizing the existing training center, new modules ensure that technical and social skills, especially those needed behind the customer service desk and amid a diversifying workforce-a workforce with women-are upgraded at all levels of the utility.

The training program has enjoyed generally sustained growth. Intensified training in 2010-2011 increased expenditure on training by almost $60 \%$, the number of courses by $70 \%$, and participants by $90 \%$. 


\section{Service Minded is People Minded}

On any given day, customers-individually and in groups-stream through Faruk Hossain's office to talk about their bills or a water leak or worries that pending construction in their neighborhood might interrupt the water supply.

Hossain is the head of revenues and customer relations for zone 3 , and the new training programs of the Dhaka Water Supply and Sewerage Authority (DWASA) have reoriented staff to make them more service-minded and understand DWASA's operations better.

On this particular day, Hossain's office is full of customers asking why their latest bill was higher than expected. Hossain explains that the bill is the effect of their new meters, which are likely to be giving a more accurate reading than the old ones.

The customers are visibly frustrated but calm. "We don't have any problem with the water or the customer service," one of the customers, Mustafa Azad Kamal, clarifies. "Now, if we don't get water, then customer service doesn't really matter, does it? But we get water, and paying the bill is easy." His problem was the bill itself. It was higher than ever.

Hossain explains that many customers are finally paying the real price of their consumption. In the past, some customers bypassed the meter by rigging and rerouting pipes. When DWASA discovered the tampering, it cut the offending lines, repaired pipes, and sometimes replaced meters-and billed the costs to the customers.

Hossain listens quietly, maintains eye contact with the customers, does not accept distractions from the nearby cellphone on his desk. He answers the customers. Then explains again, and some more.

"I've learned some new things in the training: how to behave with customers," Hossain said. "I have to know the problem to find the solution. I've learned to be friendly, to listen to their problems with patience."

"I've learned some new things in the training: how to behave with customers. I have to know the problem to find the solution. I've learned to be friendly, to listen to their problems with patience."

Md. Faruq Hossain, project manager for zone 3, revenue section
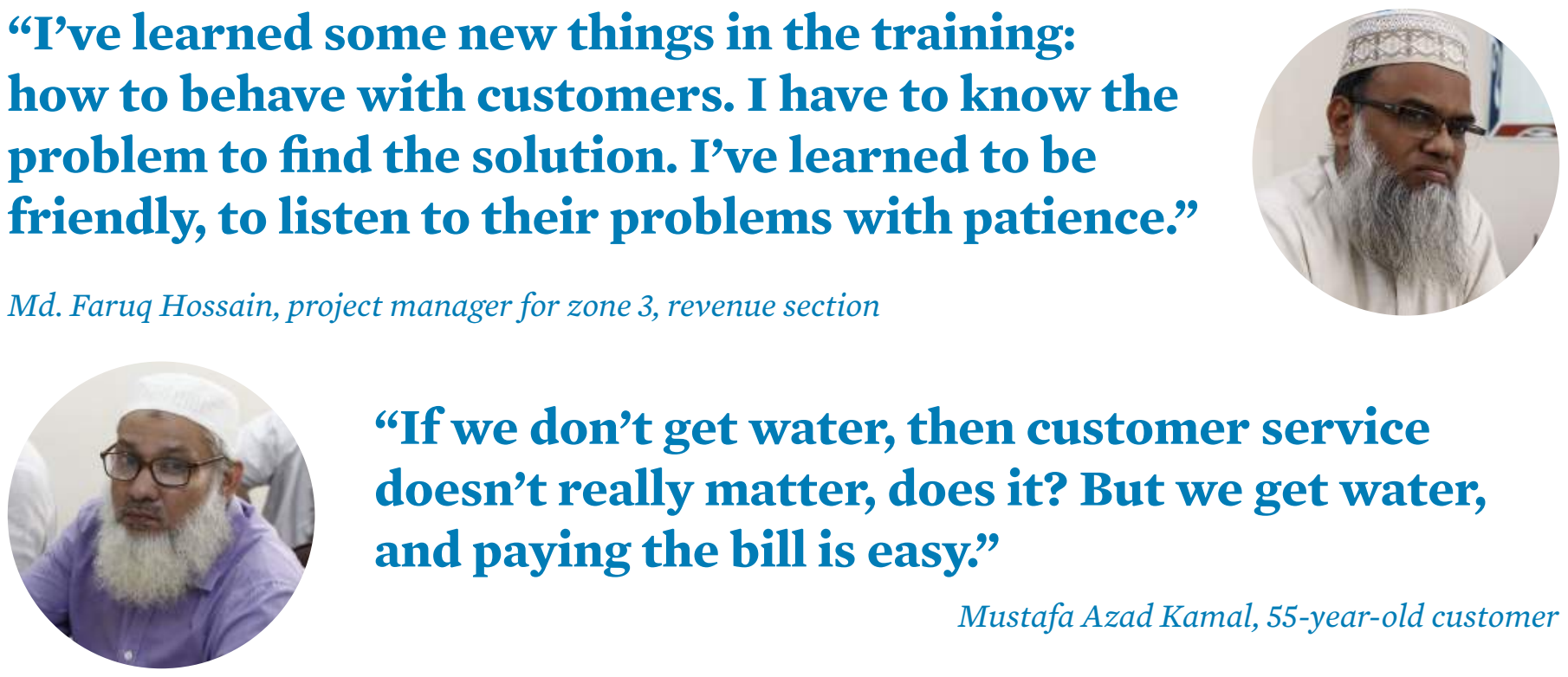

"If we don't get water, then customer service doesn't really matter, does it? But we get water, and paying the bill is easy." 


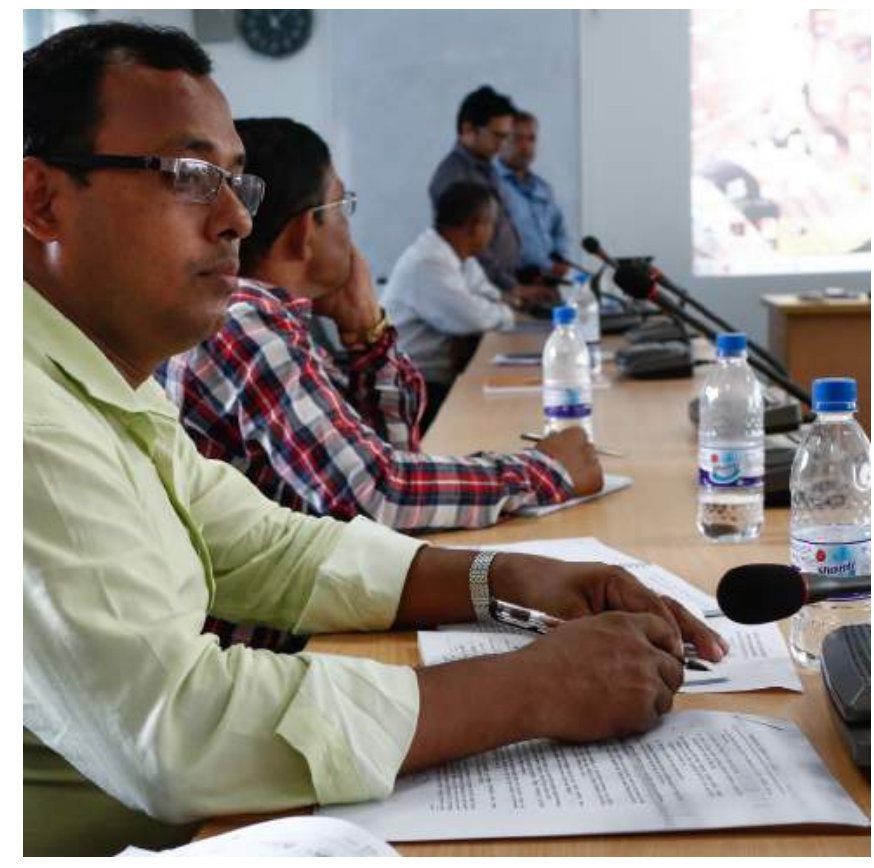

Modules were developed for 137 new courses (see "New Training Courses" box below). During the program loan period, five training officers were recruited, and more than 108 training courses were conducted for more than 1,800 staff.
A key feature of the project, inspired by lessons from the Manikdi pilot project, was the training of thousands of plumbers across the city to "do no harm" to people's connections and pipes, and to acquire badly needed skills from contractual plumbers. The pilot project showed that plumbers in the project area, who would be employed for the project's infrastructure works, had little understanding of proper pipe installation and maintenance. More than 600 local plumbers were trained under the pilot project alone, to ensure the availability of good-quality tradesmen for the project and the maintenance to follow. Pump operators were also trained to operate the pumps, valves, and chlorination equipment, and to do the testing.

The capacity-building program extended beyond internal training to programs at technical institutes and schools, the secondment of DWASA staff to contractors to gain hands-on experience, and human resource development planning (see infographic on the next page).

\section{New Training Courses}

Following an assessment of training needs and perceived needs, courses were developed for Dhaka Water Supply and Sewerage Authority (DWASA) officials and training team members in the following areas:

- general management

- business and financial management

- operation, maintenance, and sustainability of district metered areas

- gender-based perceptions, equality, differences, and issues

- information technology

- technical standards

- operational geographic information systems (GIS) for water networks
- nonrevenue water management

- quality standards for service connections

- water quality monitoring and operation and maintenance of chlorinators for pump operators

- behavioral change and motivational training for revenue inspectors (meter readers)

- consumer awareness campaign

- water conservation

- public health factors related to water and sanitation

- staff-level skills development

- senior management workshops 


\section{Elements of the}

\section{Human Resource}

\section{Development Plan}

The capacity-building program included major recommendations for the following:

- organizational restructuring,

- Dhaka Water Supply and Sewerage Authority (DWASA) salary structure,

- staff rationalization,

- human resource development policy,

- job description template,

- training center assessment and recommendations, and

- concept paper on performance-based management.

\section{Scope of}

\section{Corporate Planning Improvements}

The transition of DWASA into a financially viable entity has involved:

- formulating and implementing a 5-year DWASA corporate business plan, which comprises investment, financial, and tariff adjustment plans;

- developing a financial model;

- developing a system for monitoring the corporate business plan;

- training DWASA staff to continue updating the plan; and

- improving management information systems.

\section{Financial}

\section{Management \\ Improvements}

The capacity-building program included tasks to promote DWASA transparency and financial integrity:

- reviewing and improving the accounting system, and preparing the chart of accounts;

- strengthening and modernizing the accounting system and staff through training, streamlining of operational flow, computerization, and identification of system and resource requirements for improved sustainability; and

- computerizing the billing system and developing alternative modes of payment.

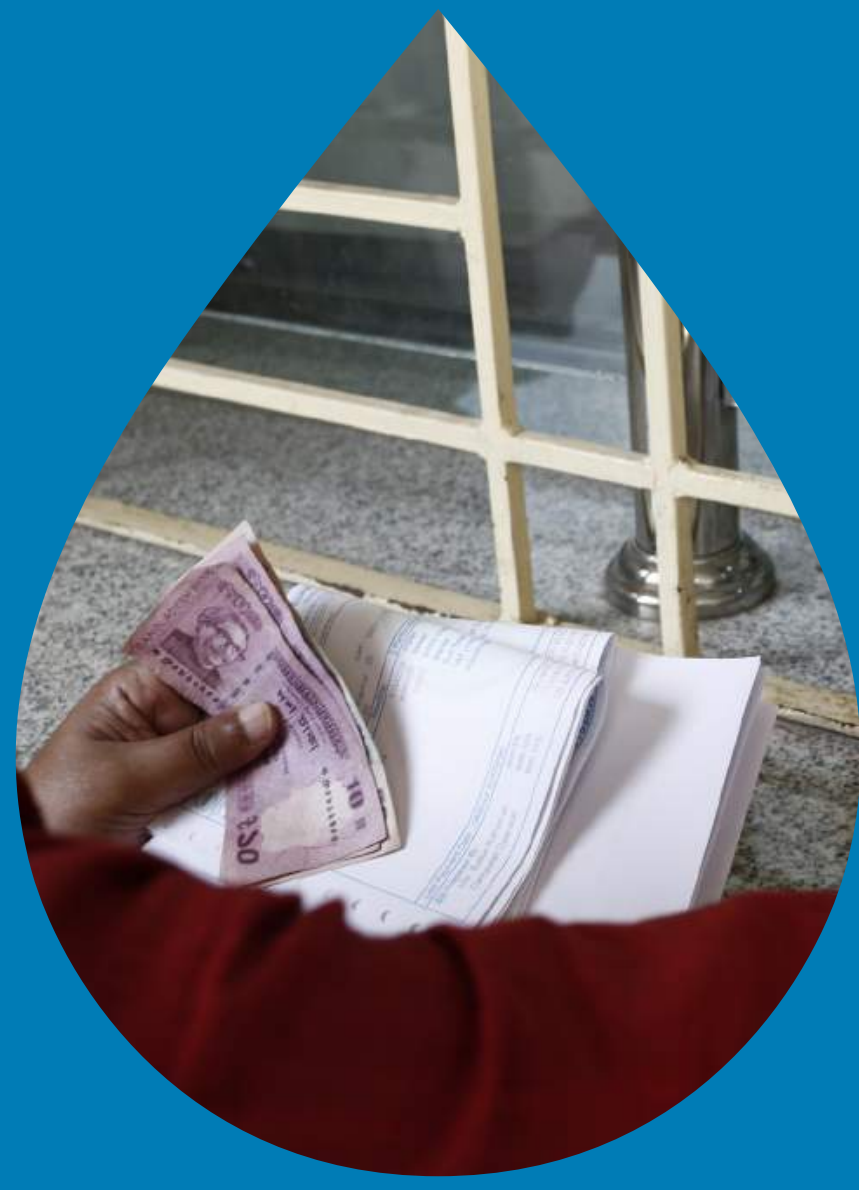




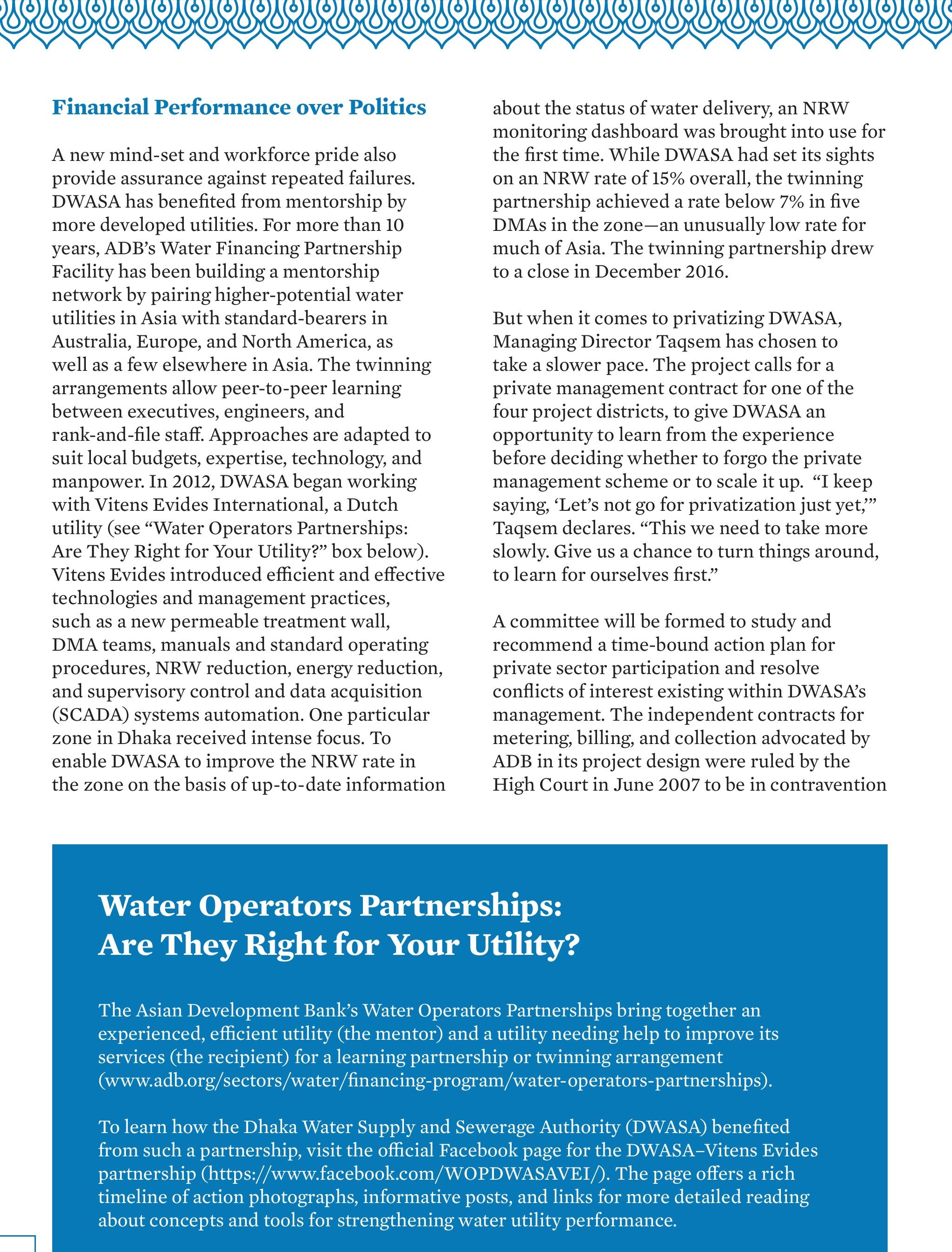

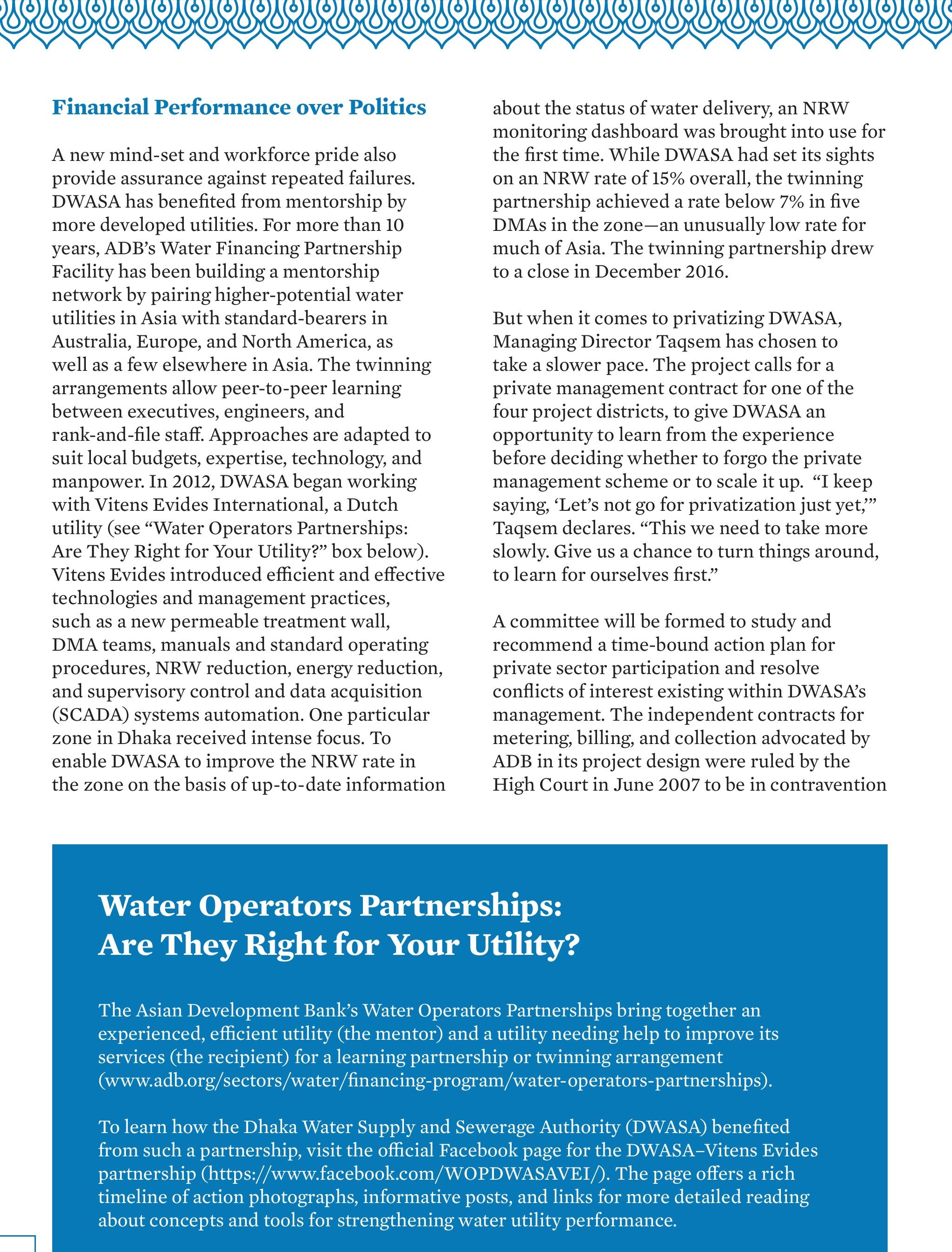

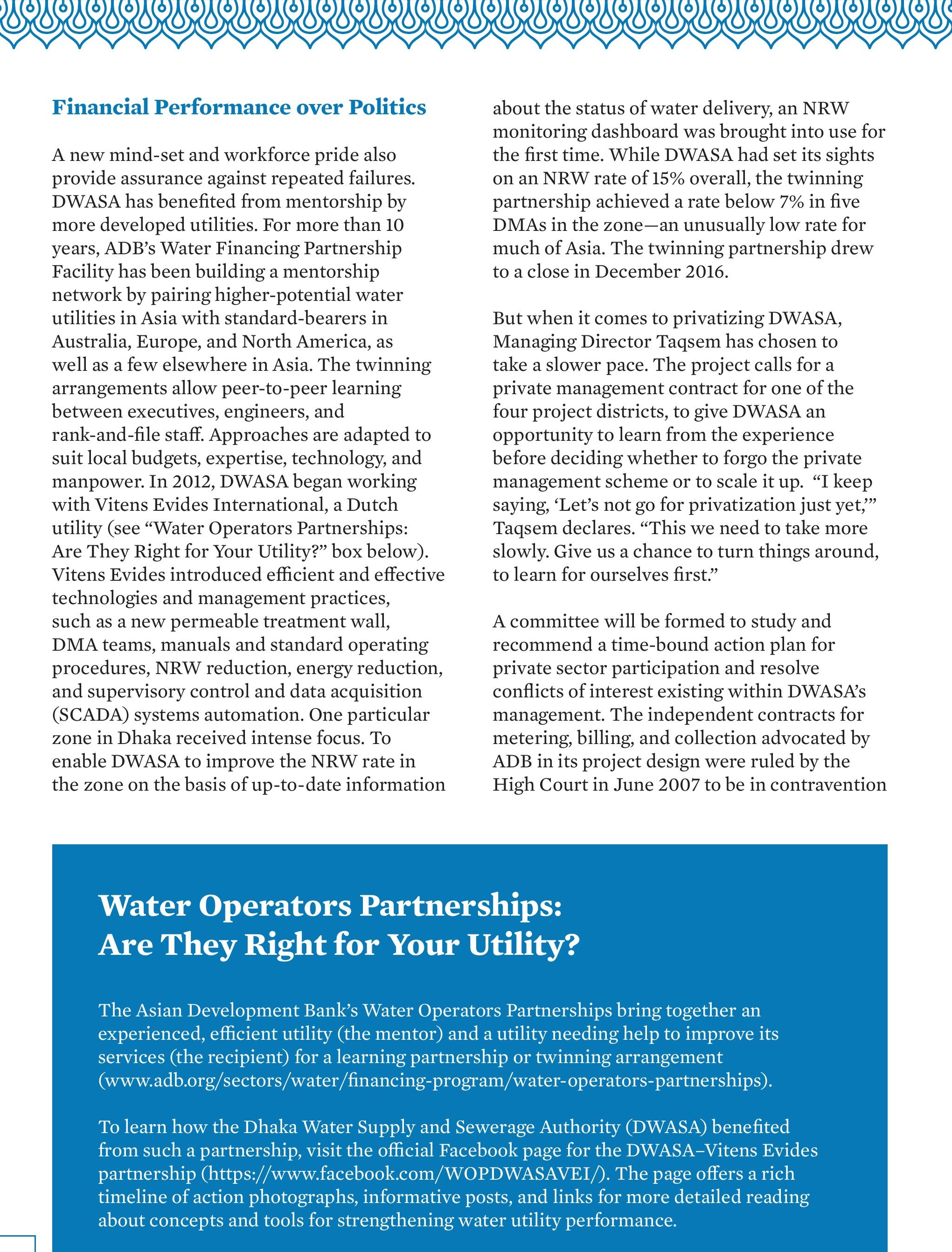

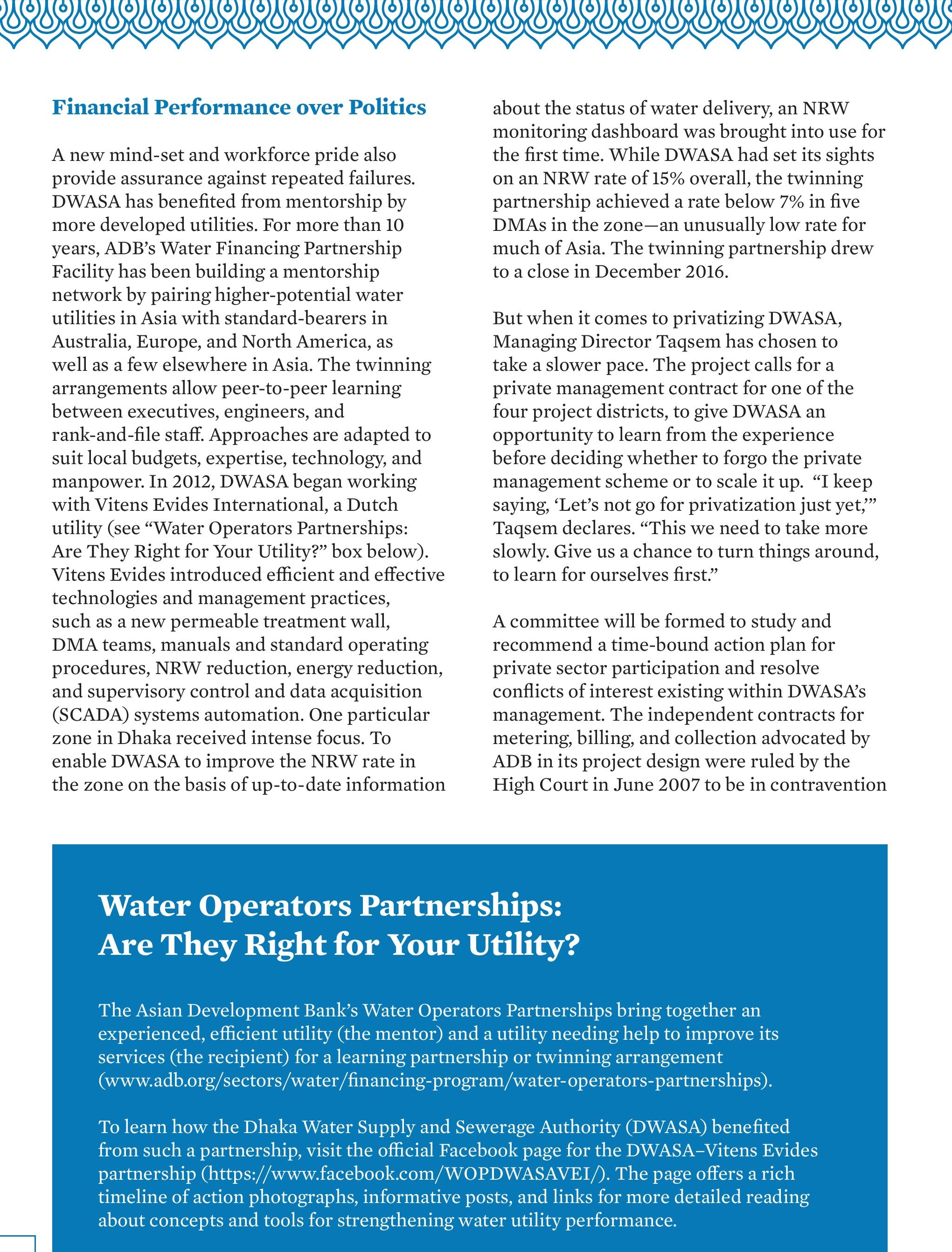

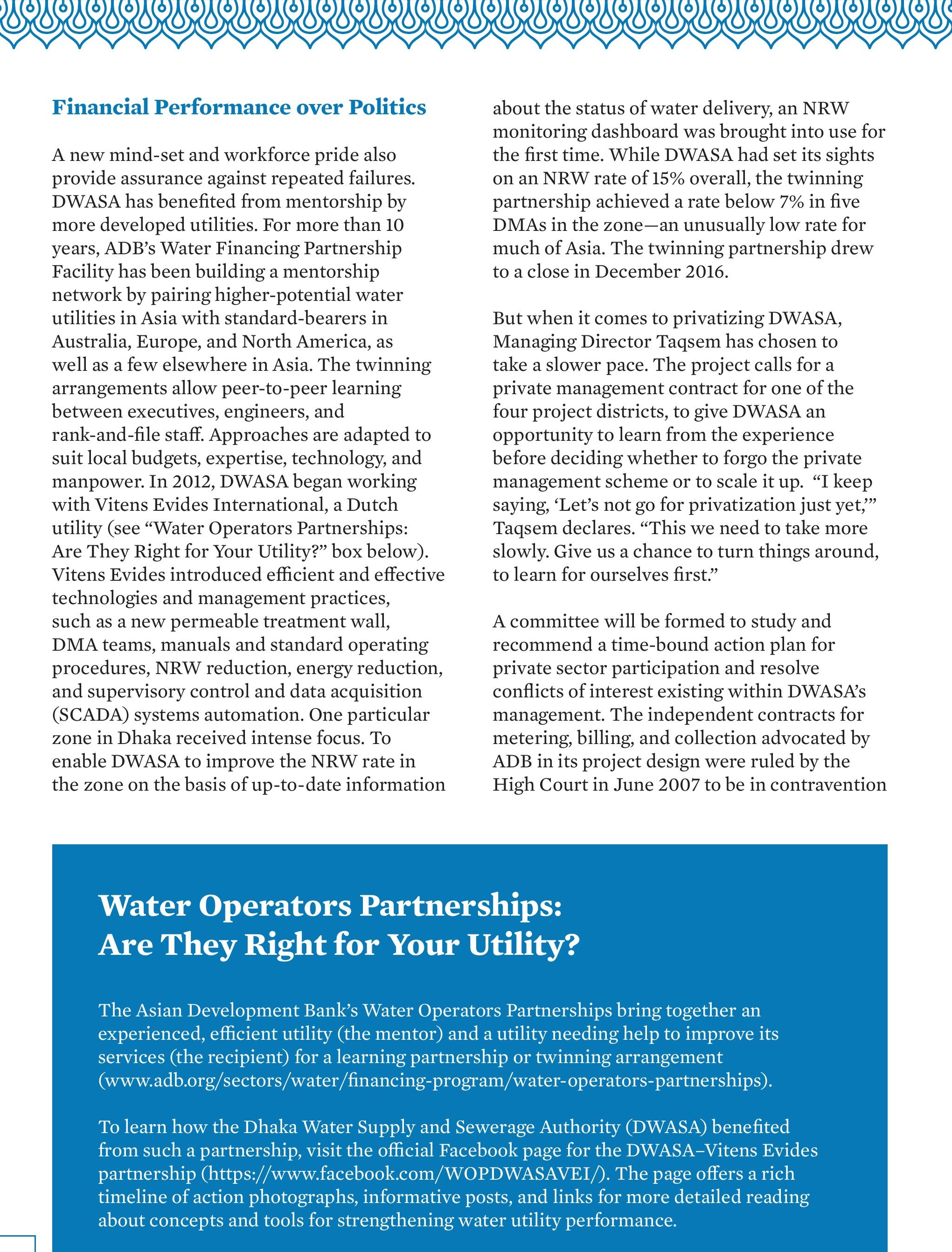

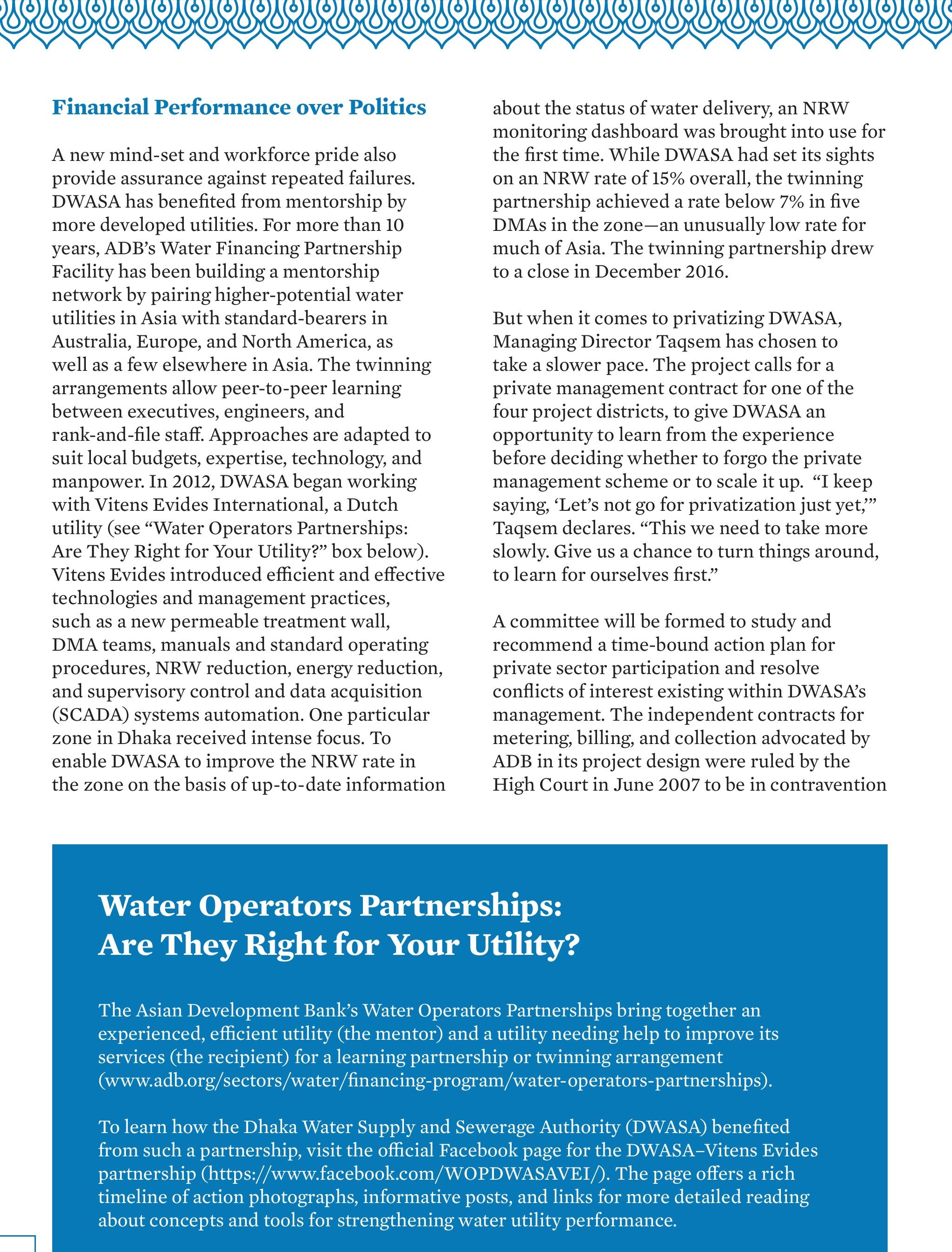

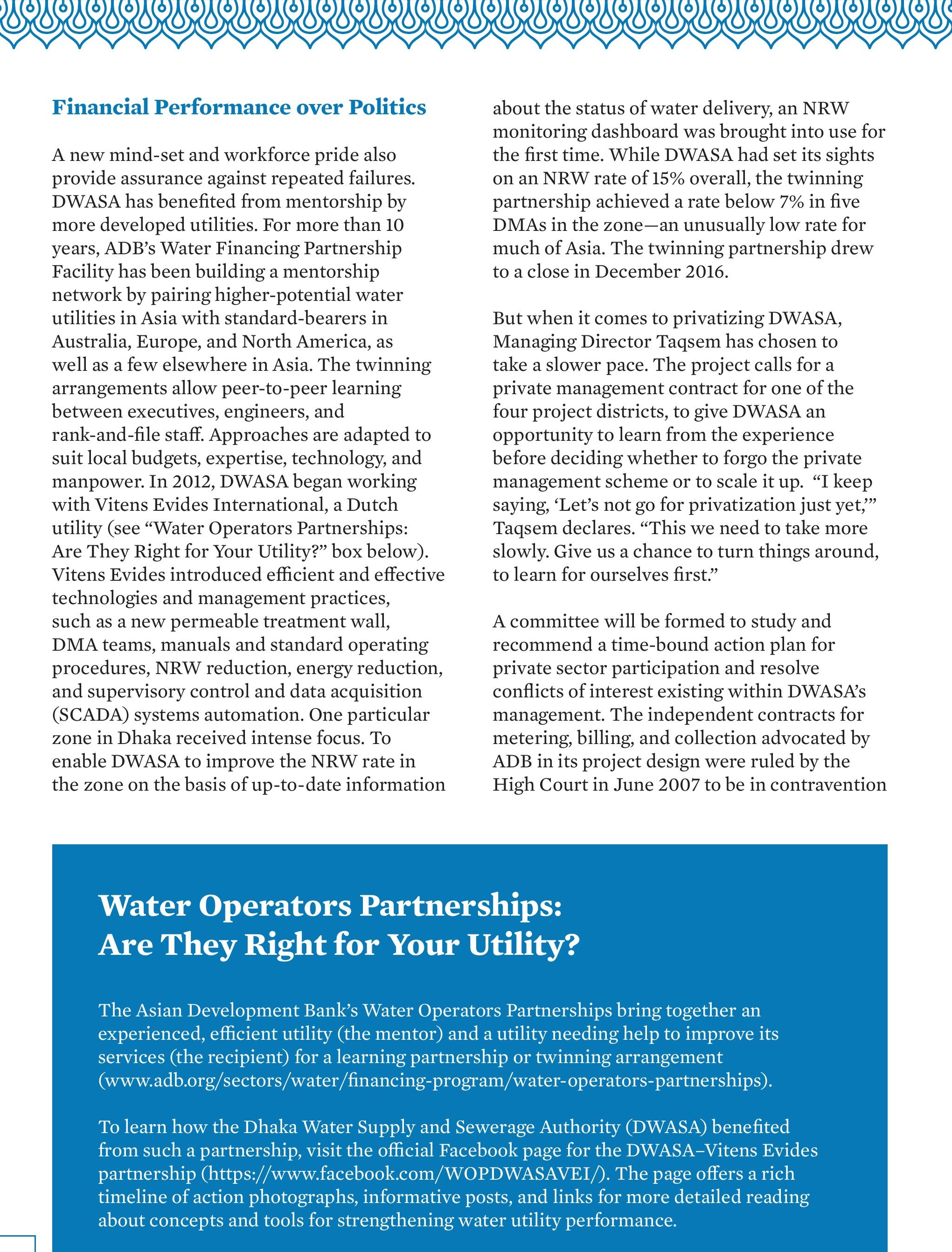

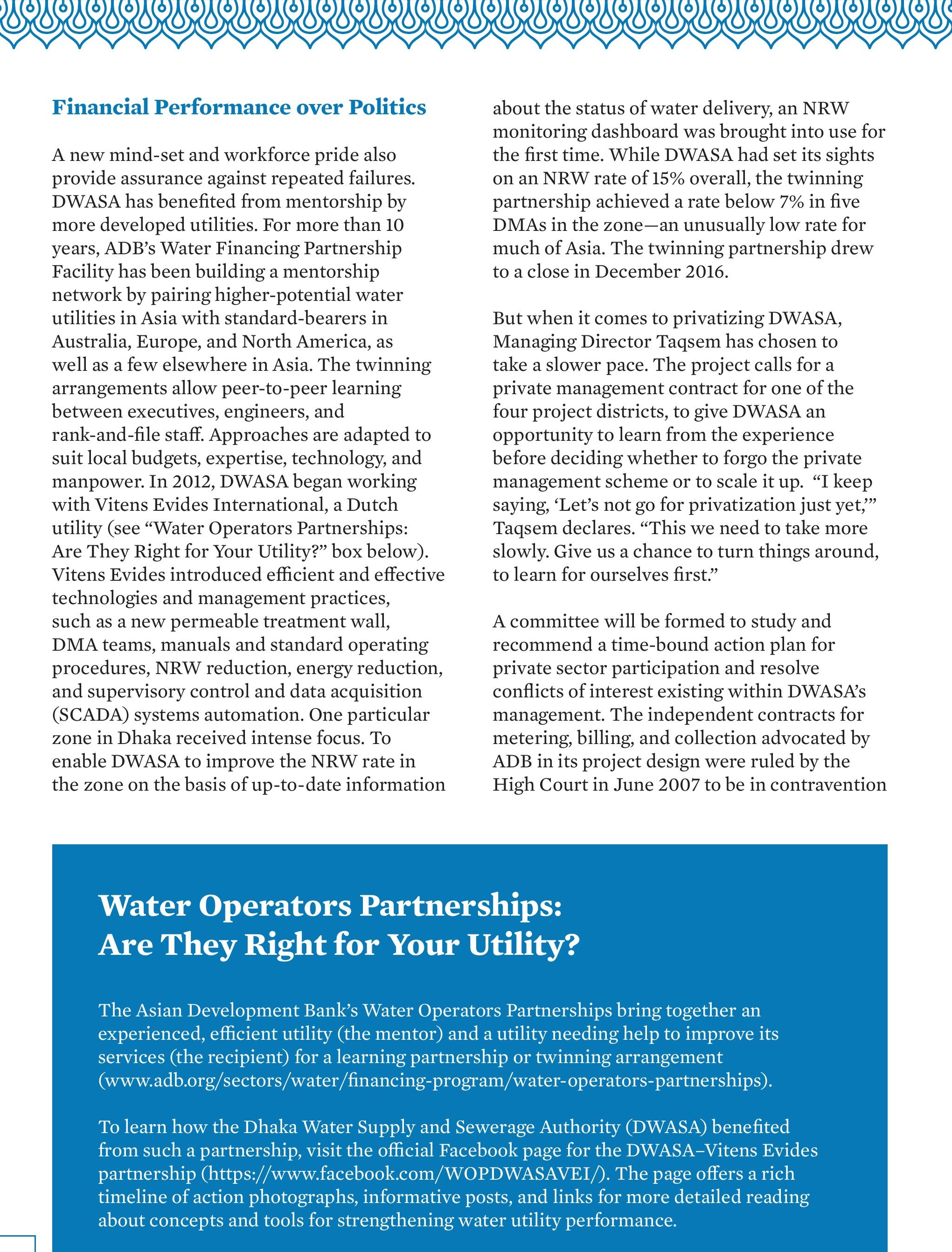

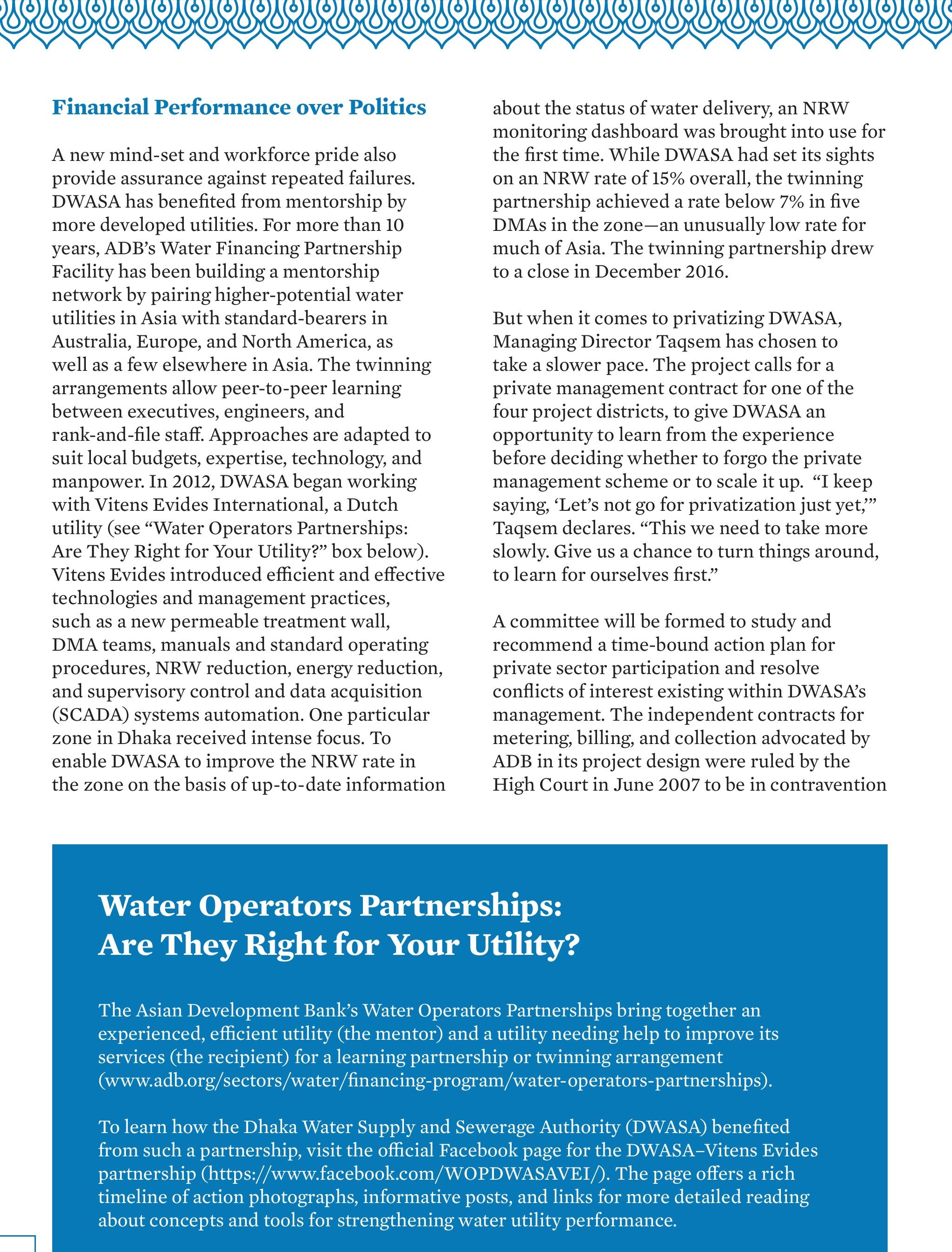

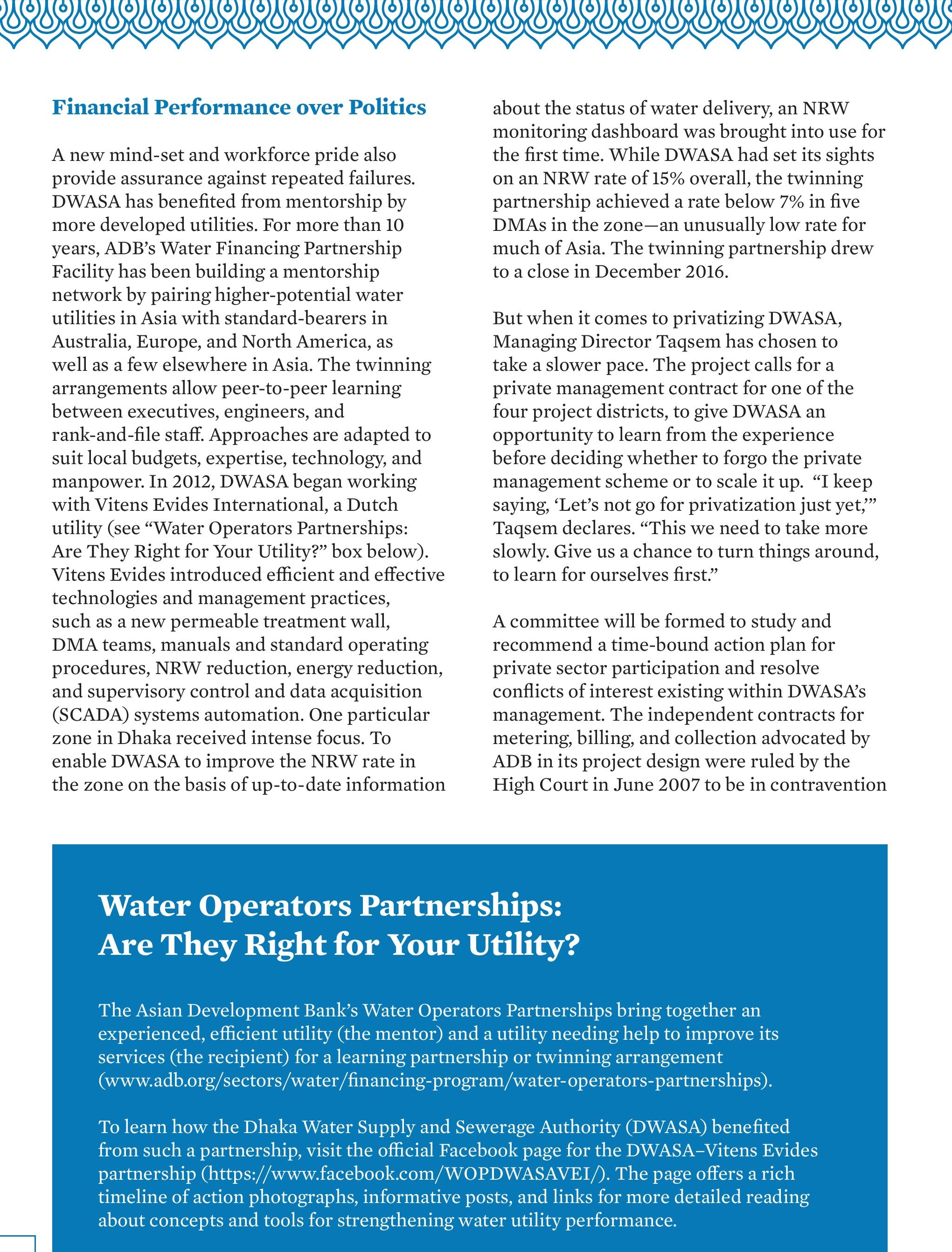

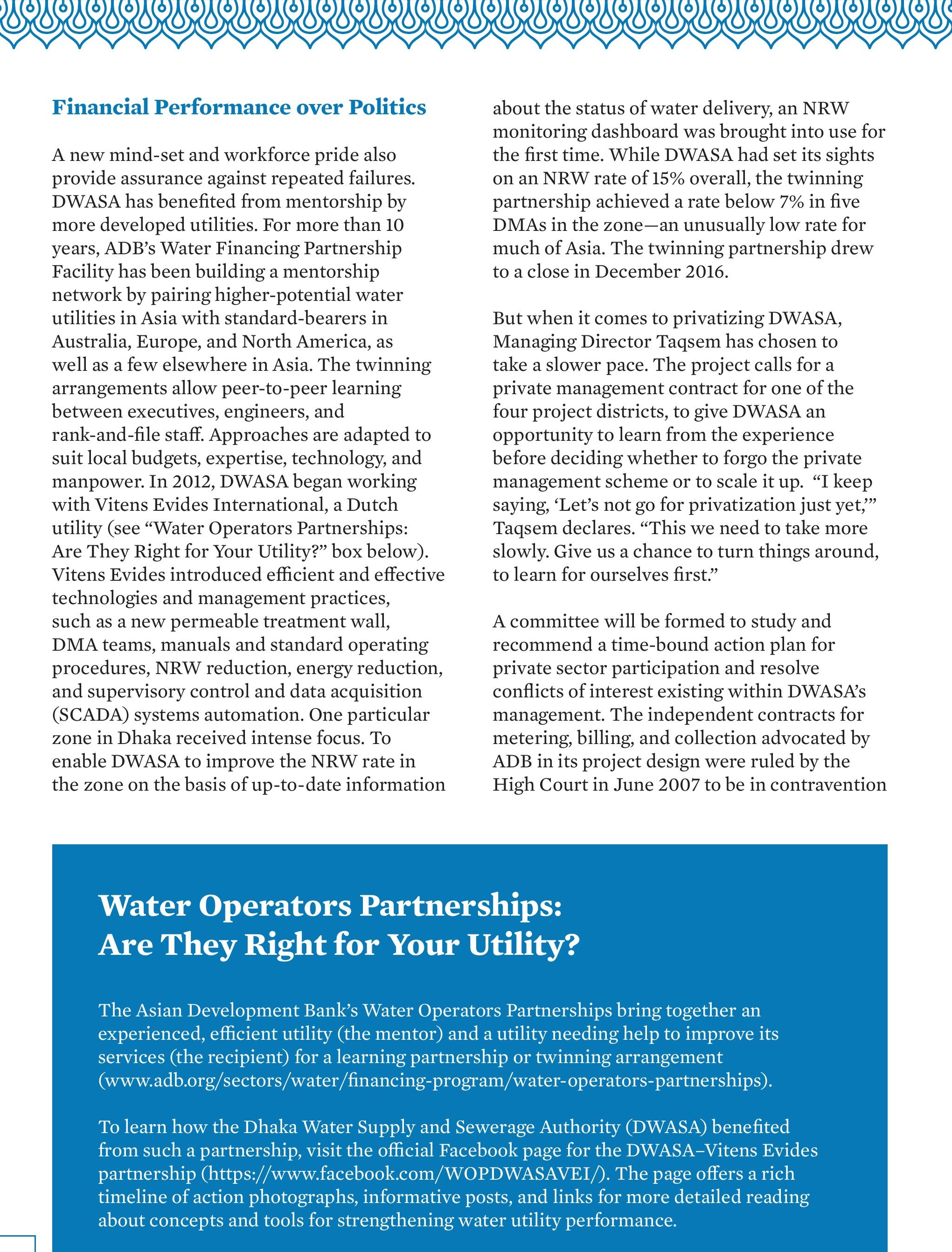

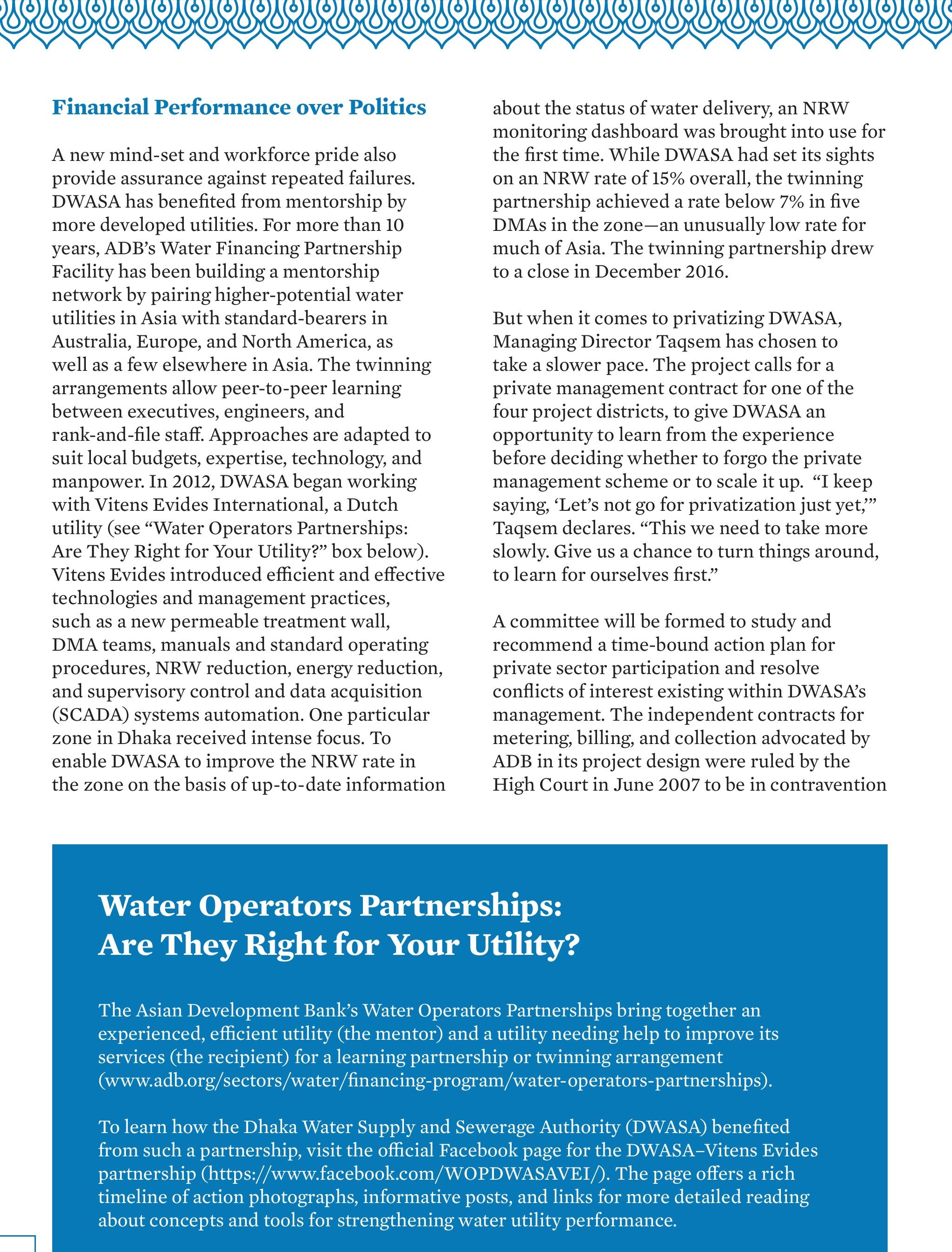

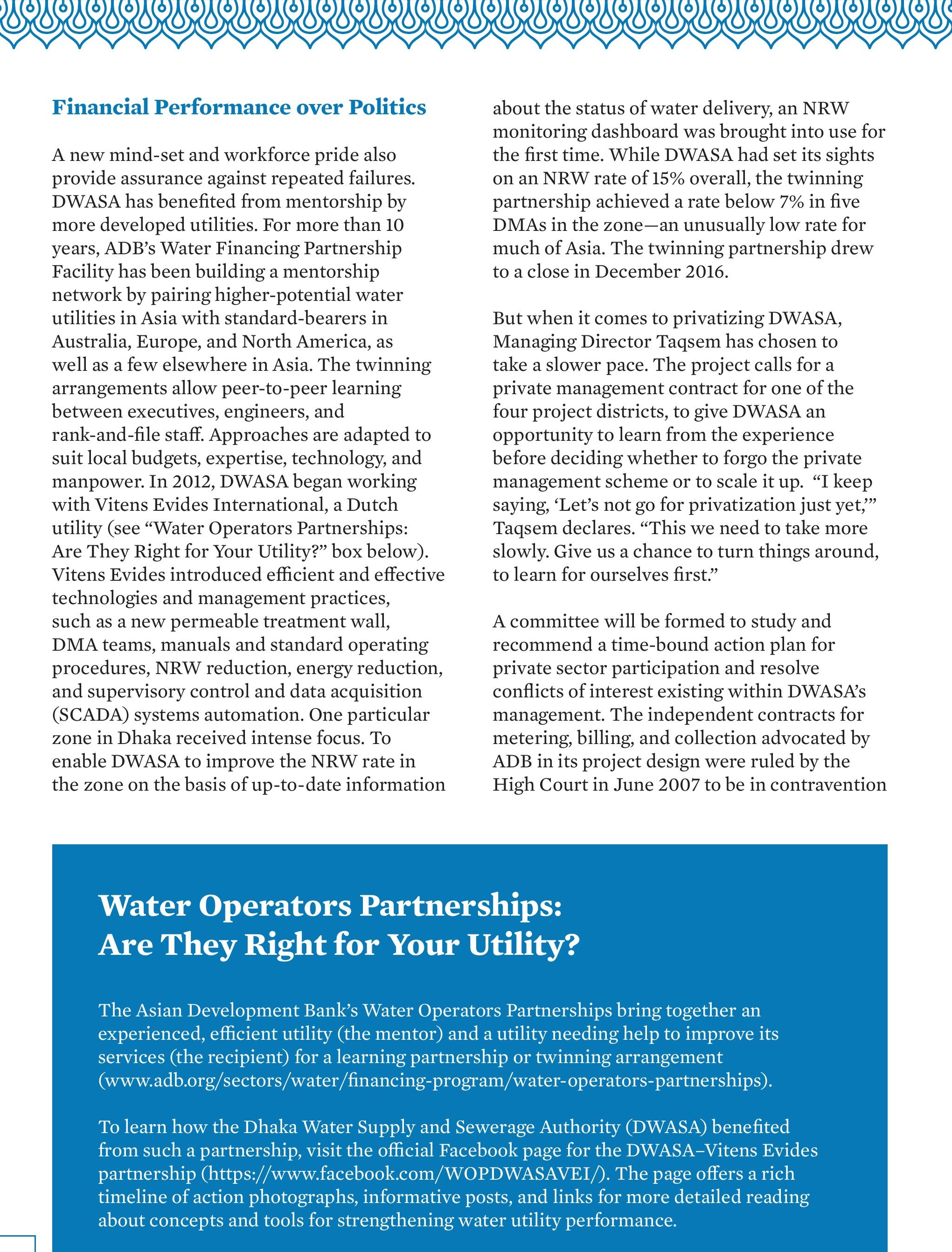

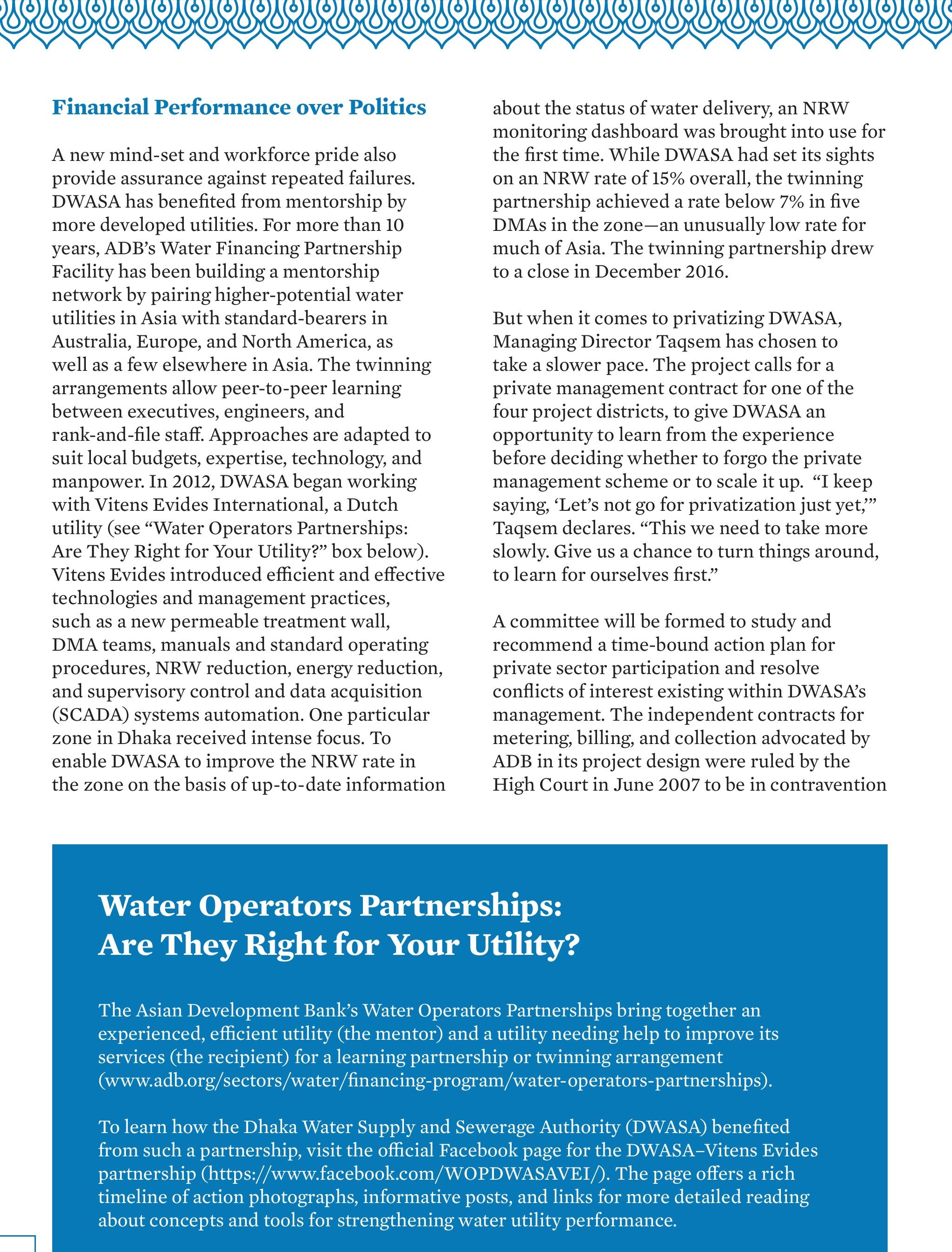

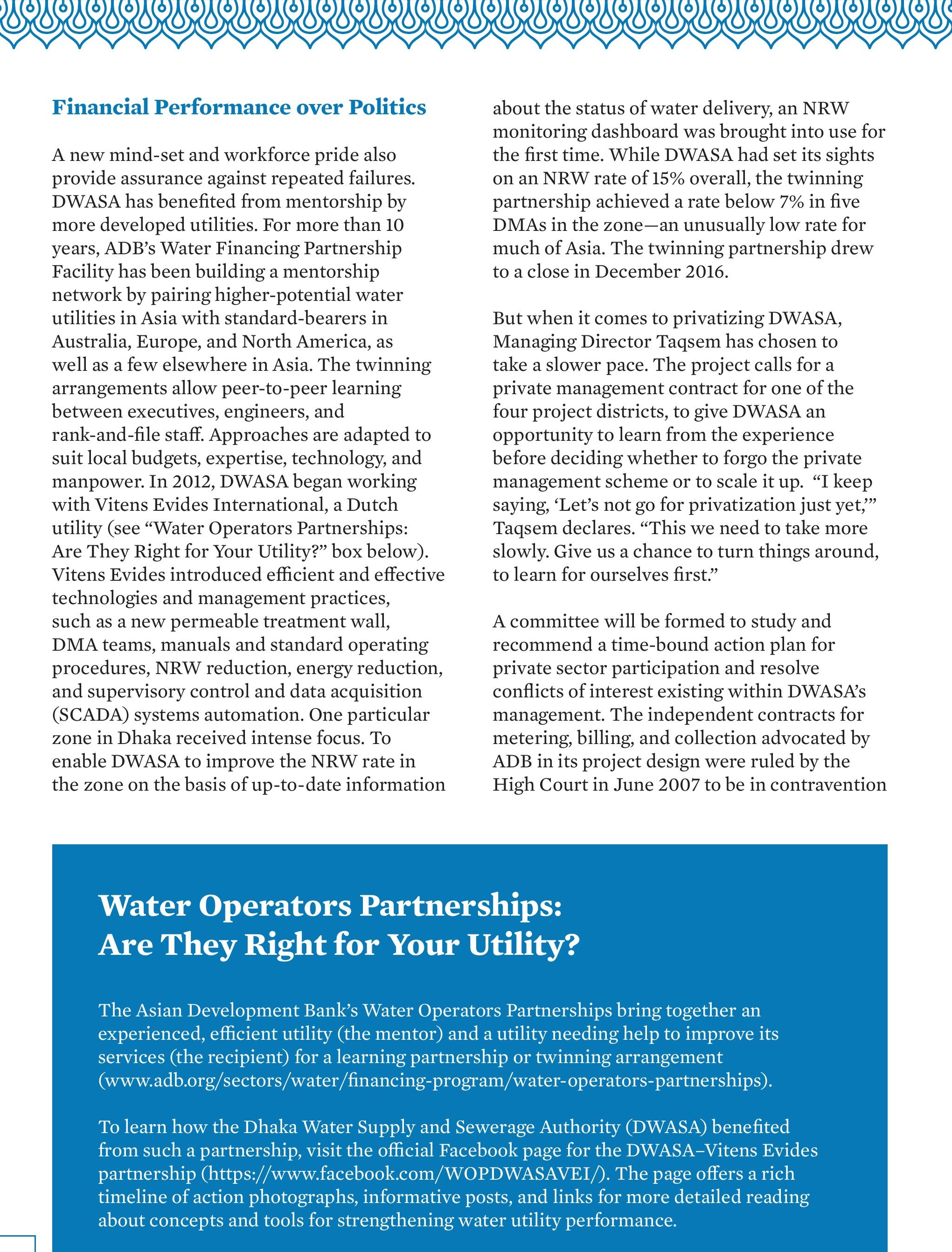

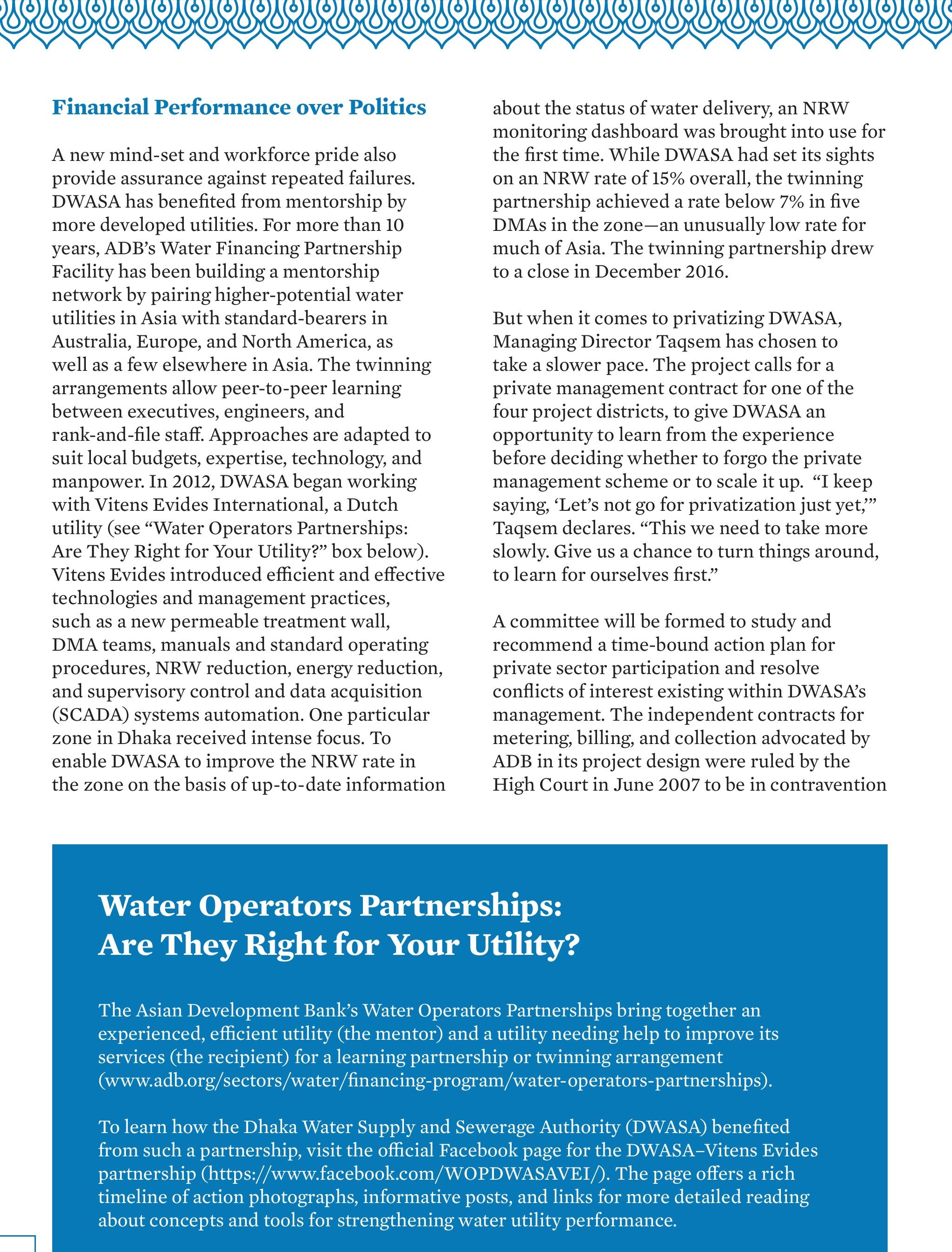

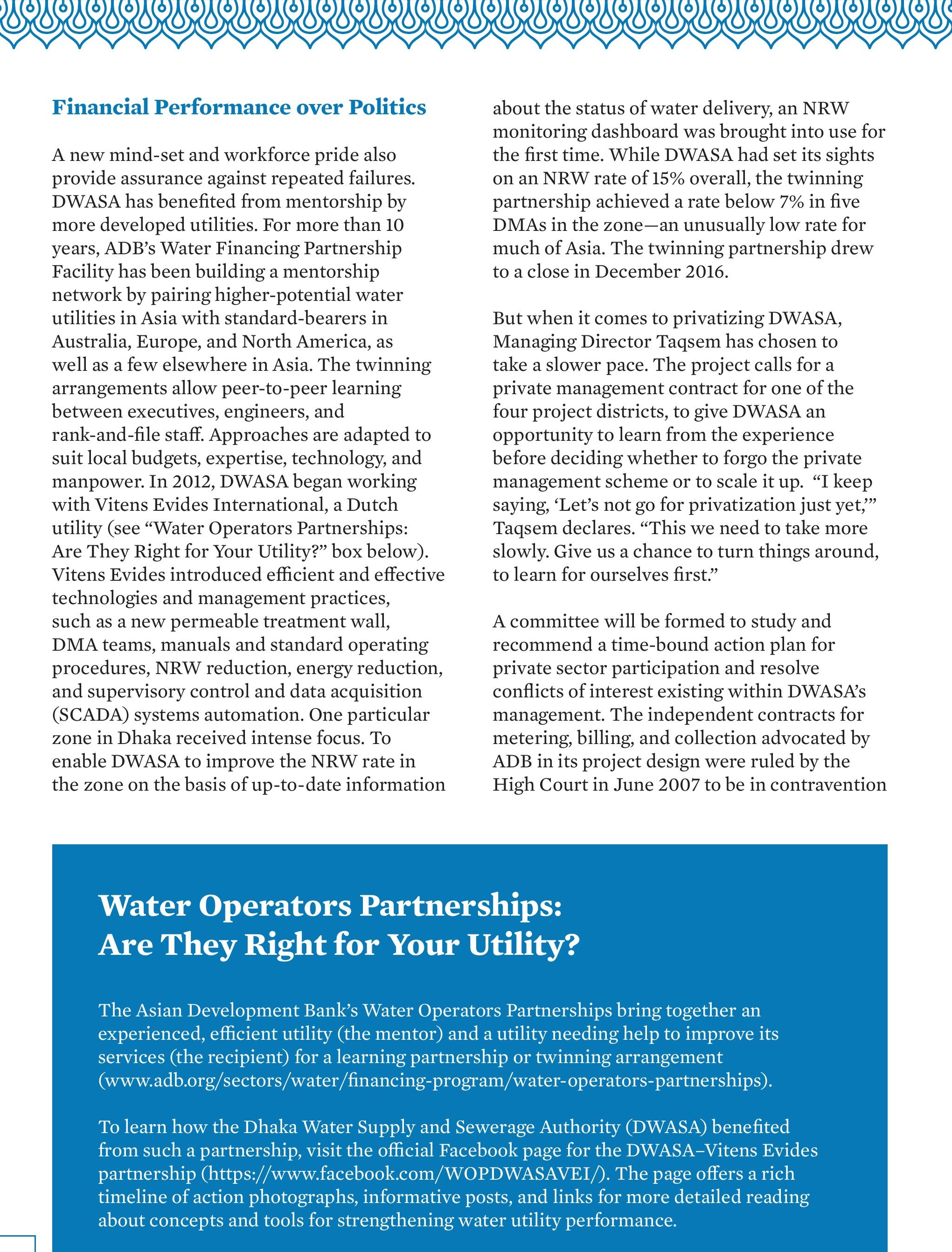

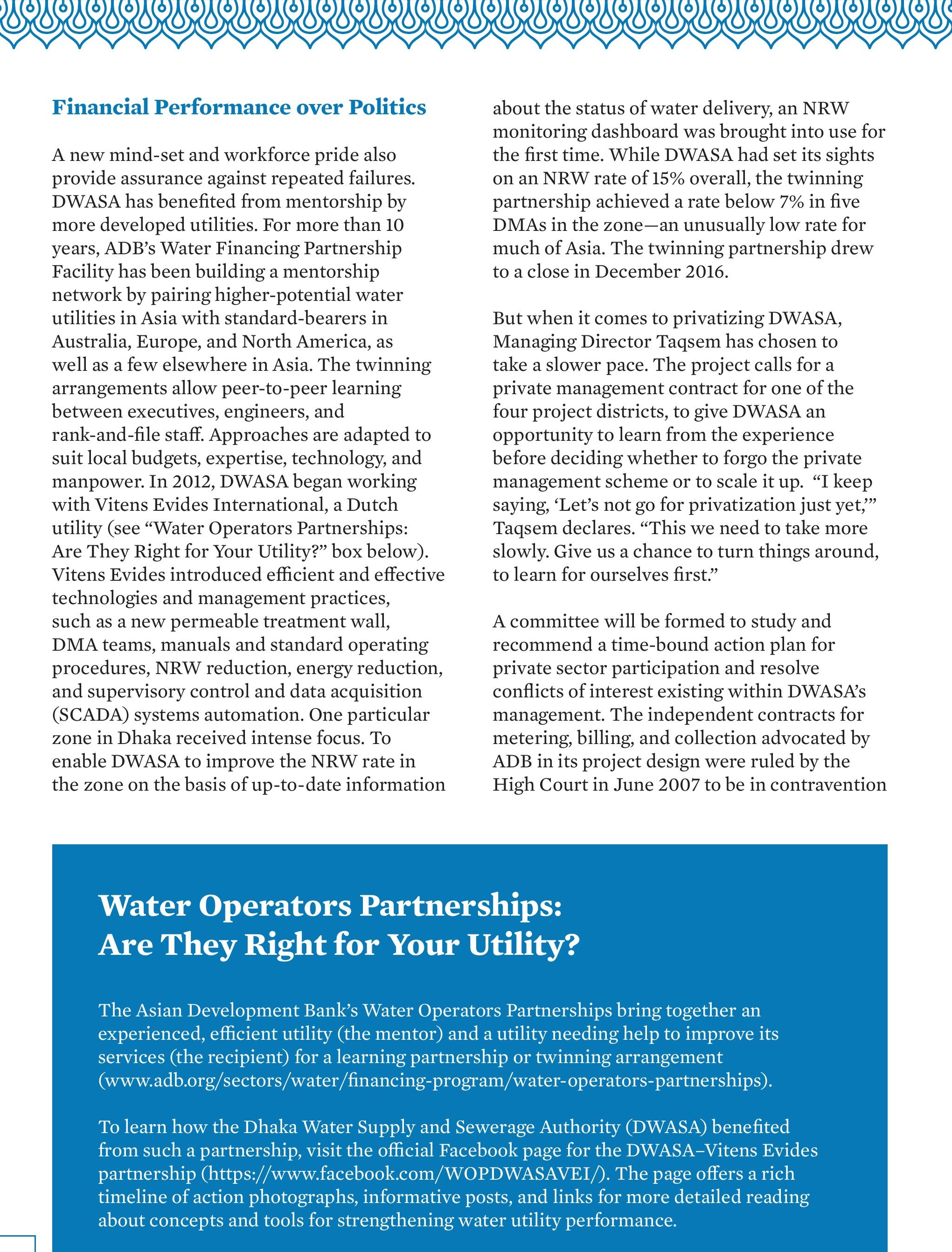

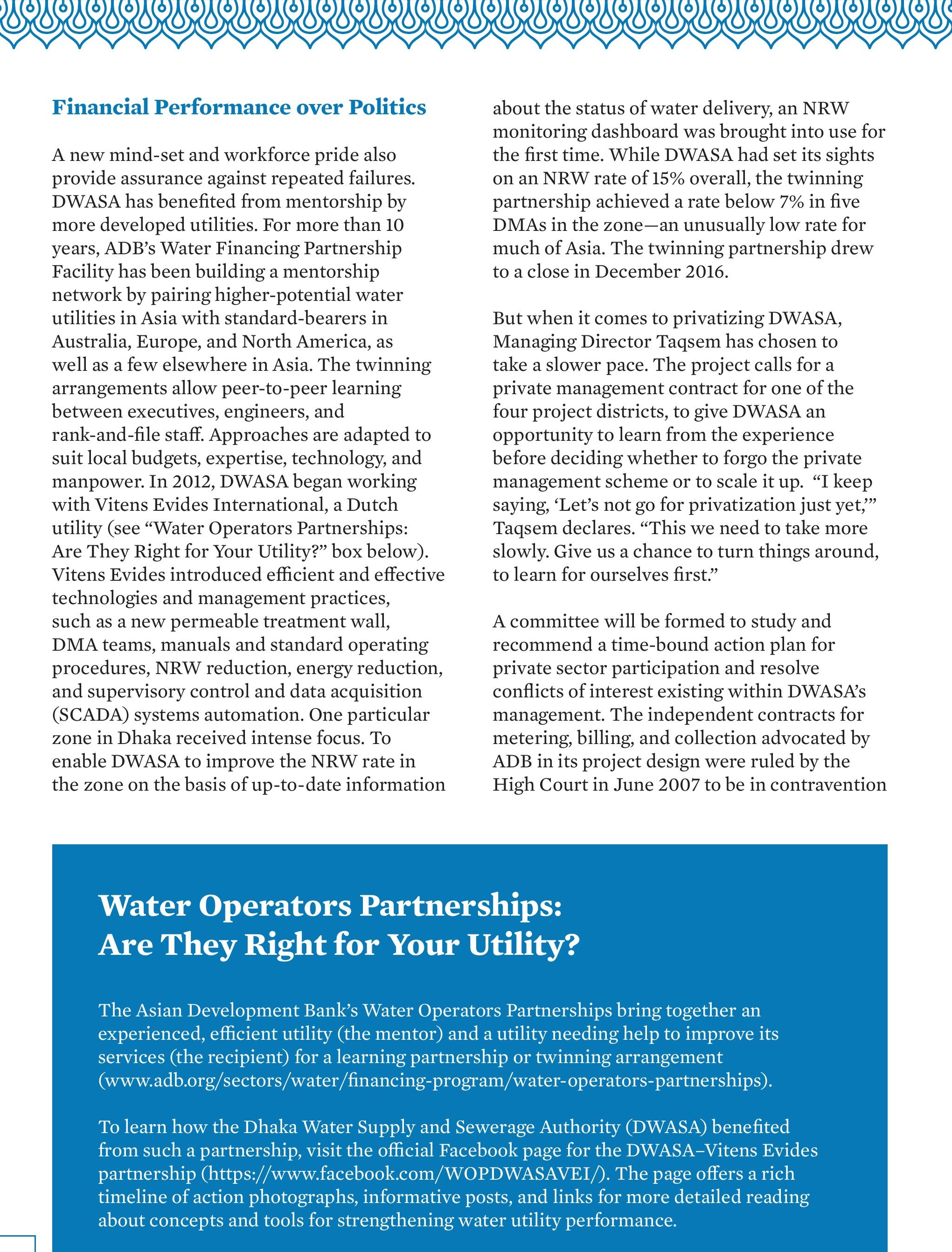

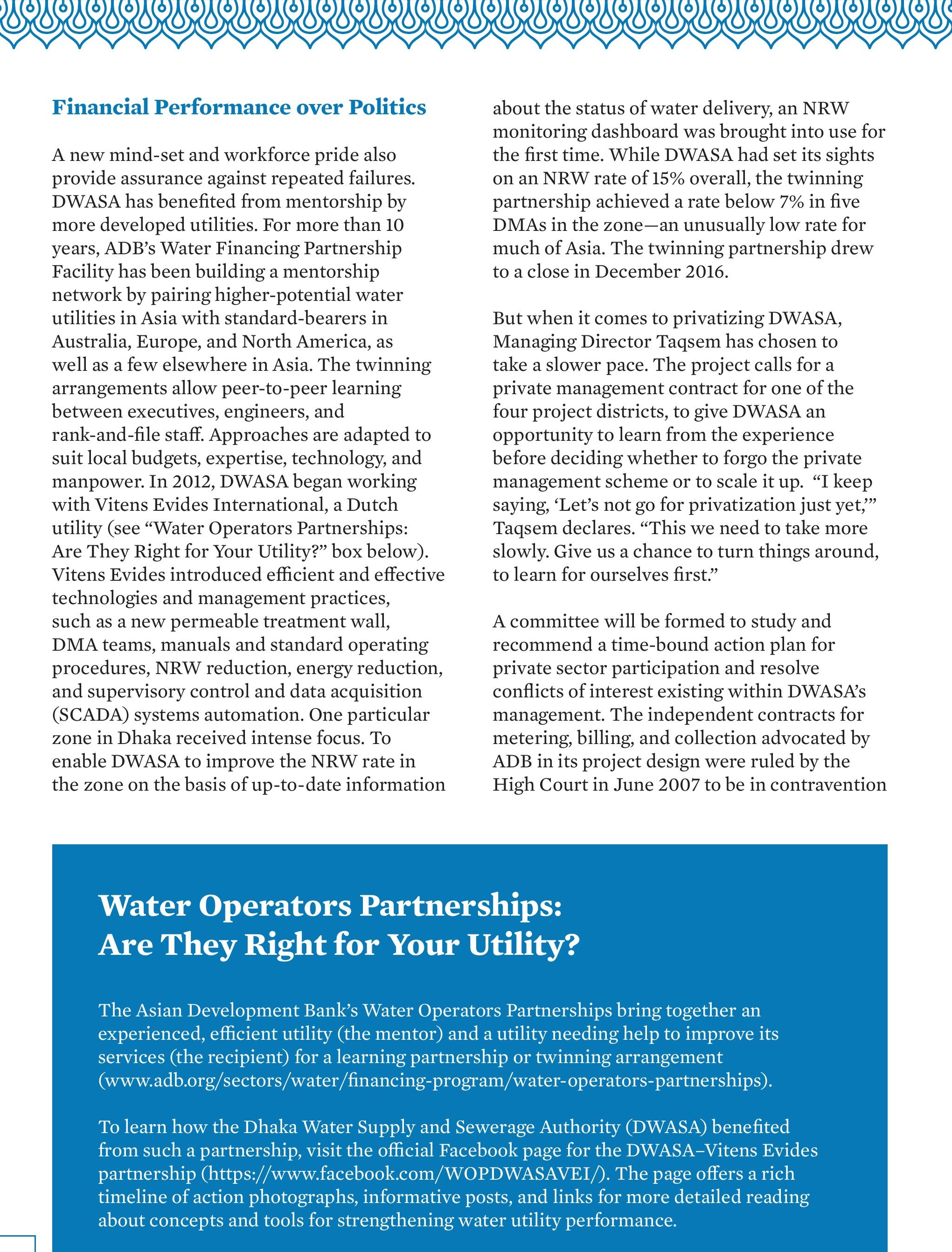

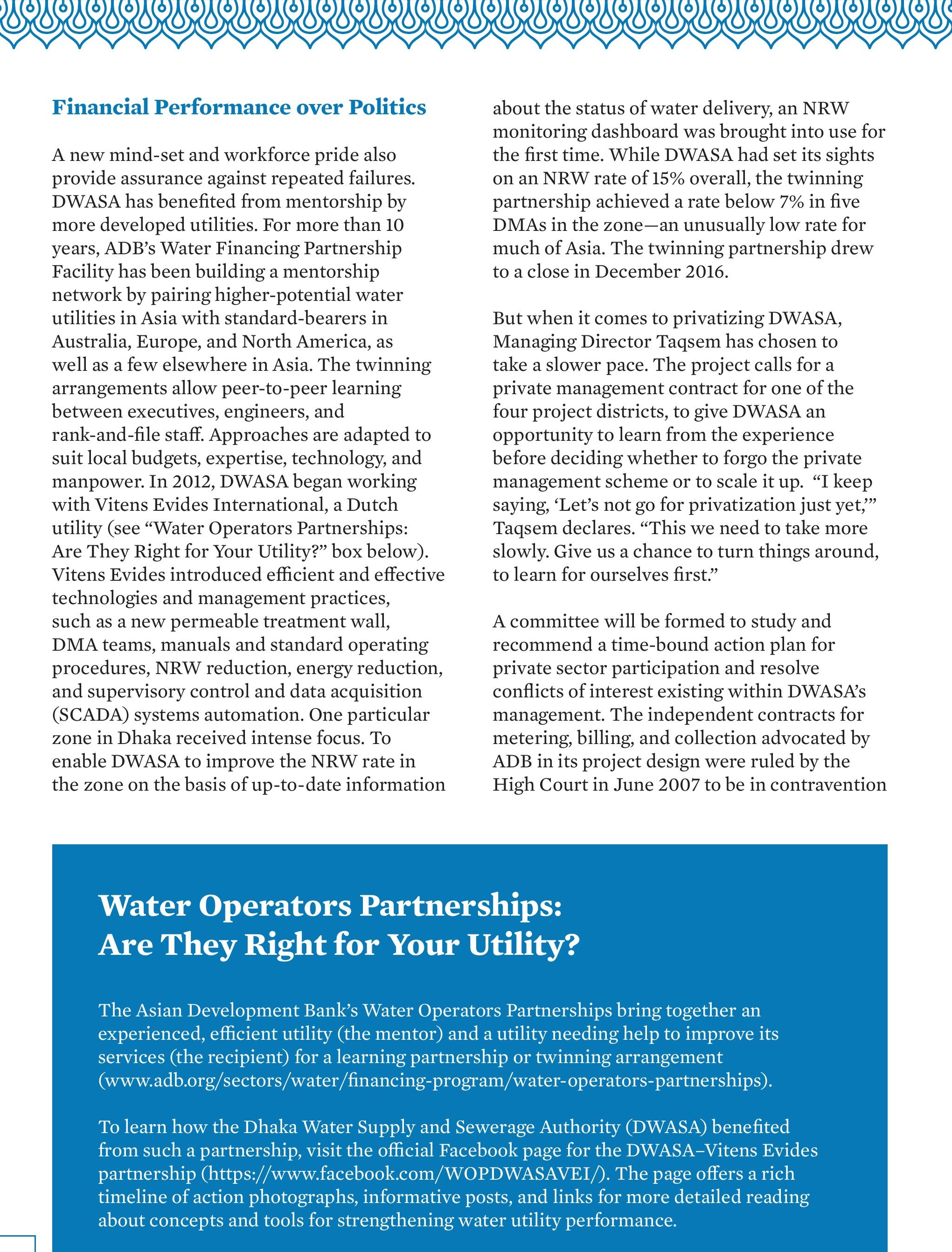

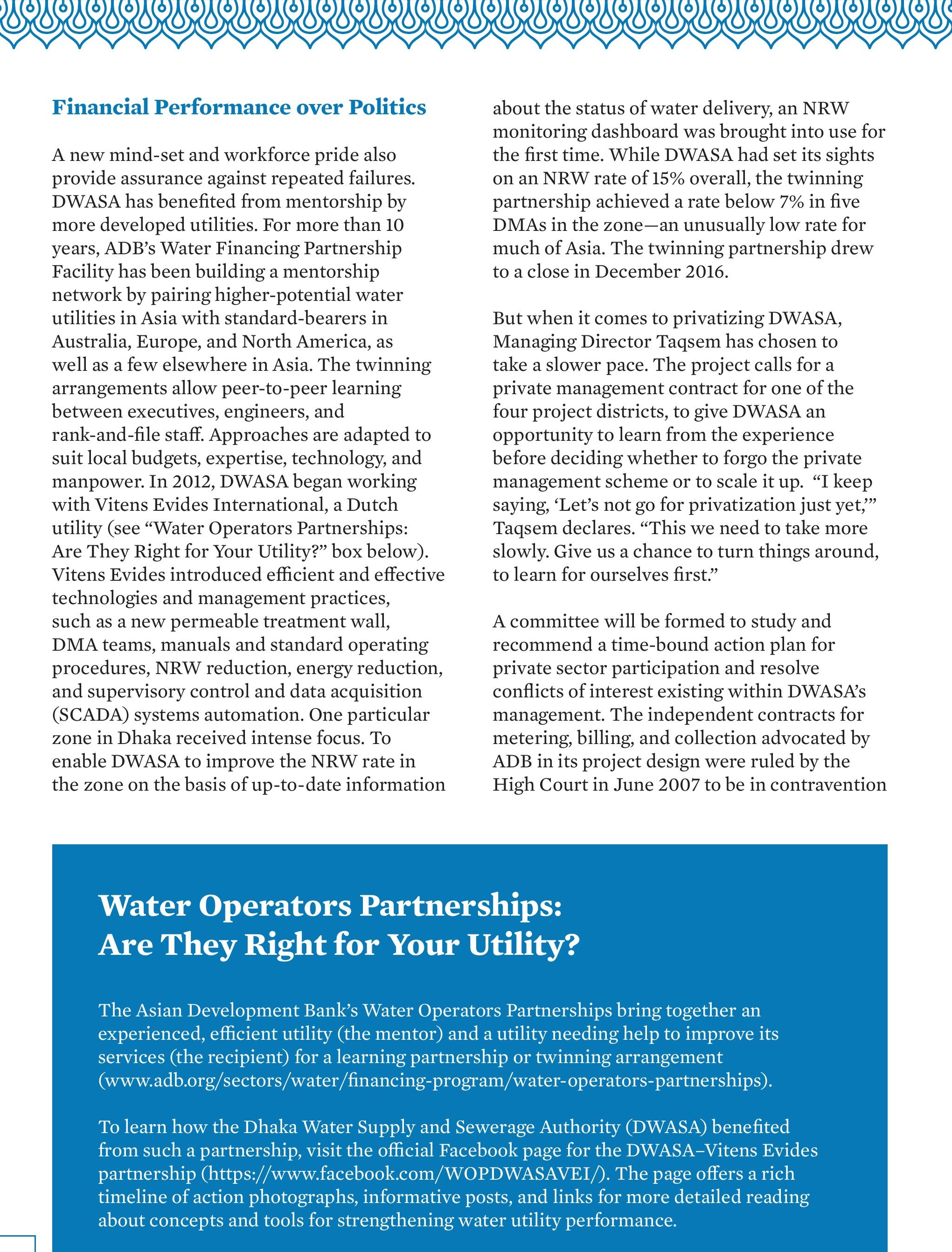

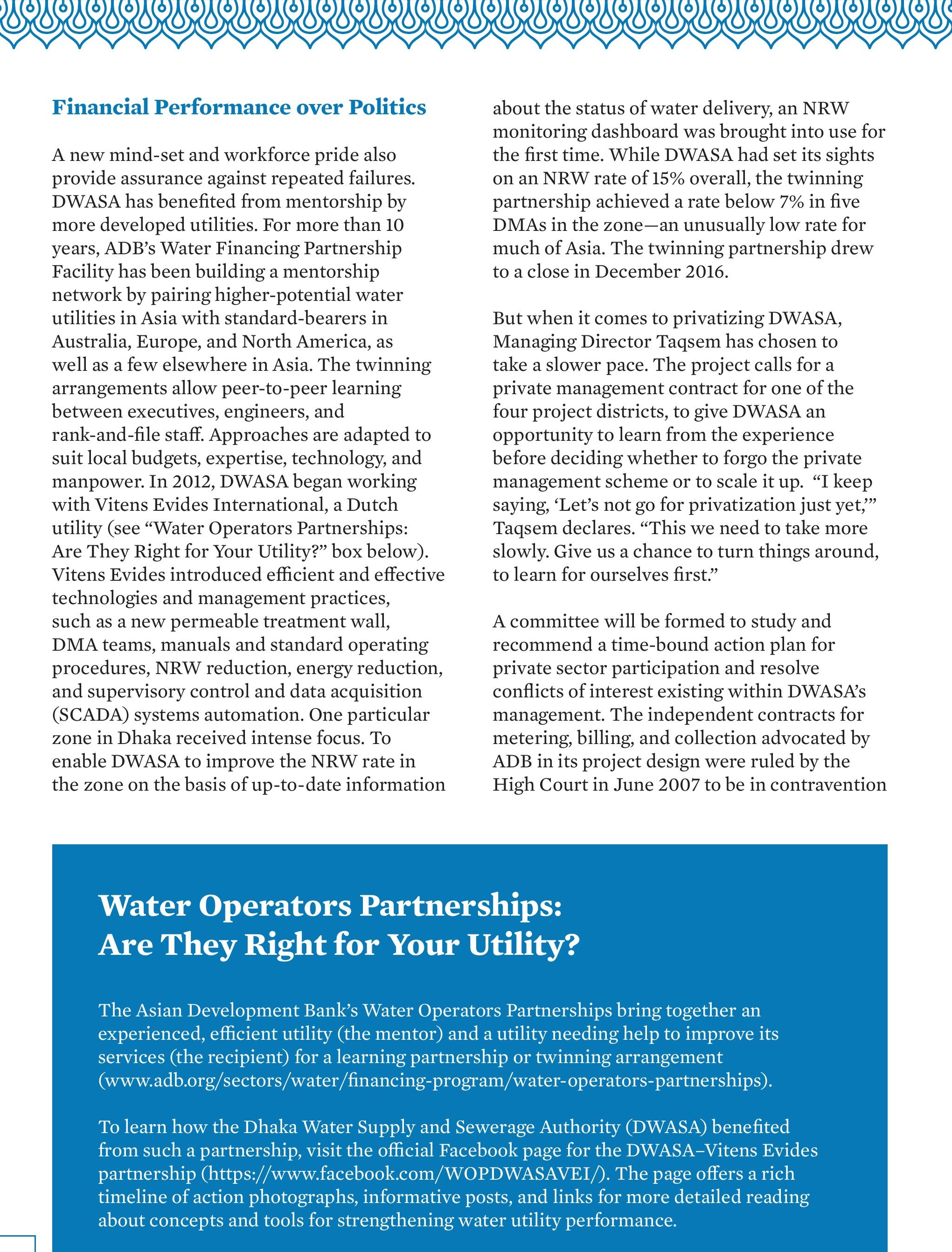

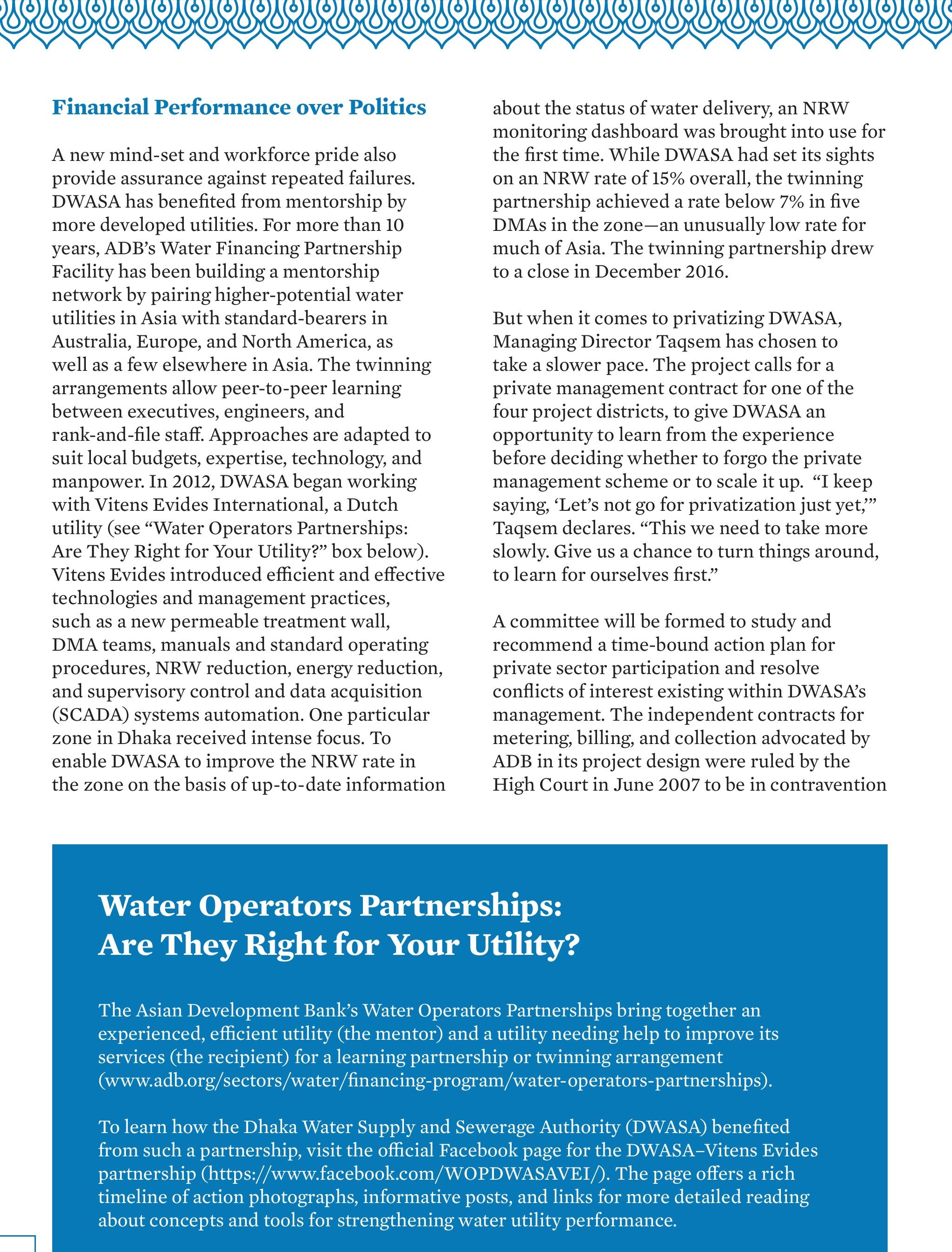

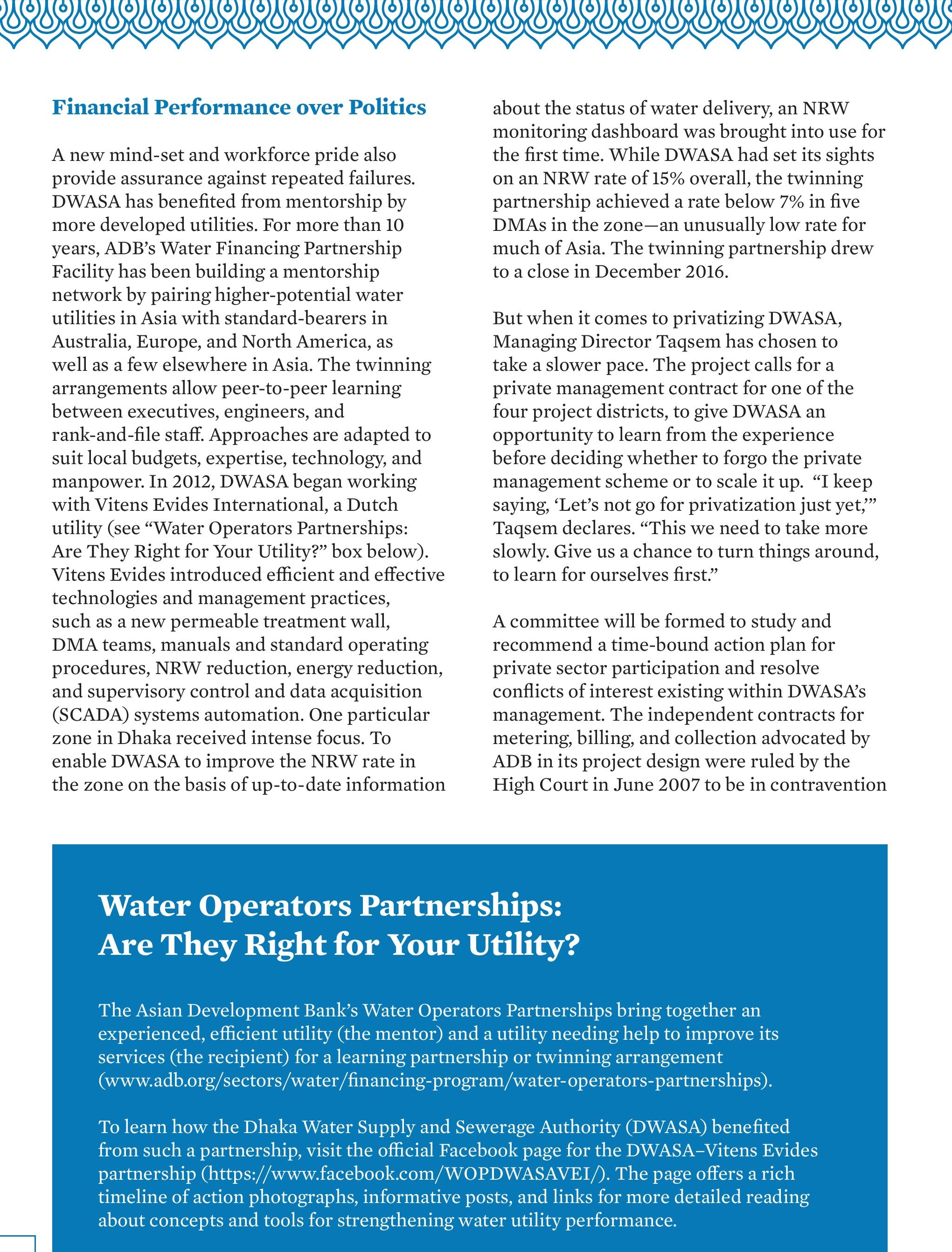

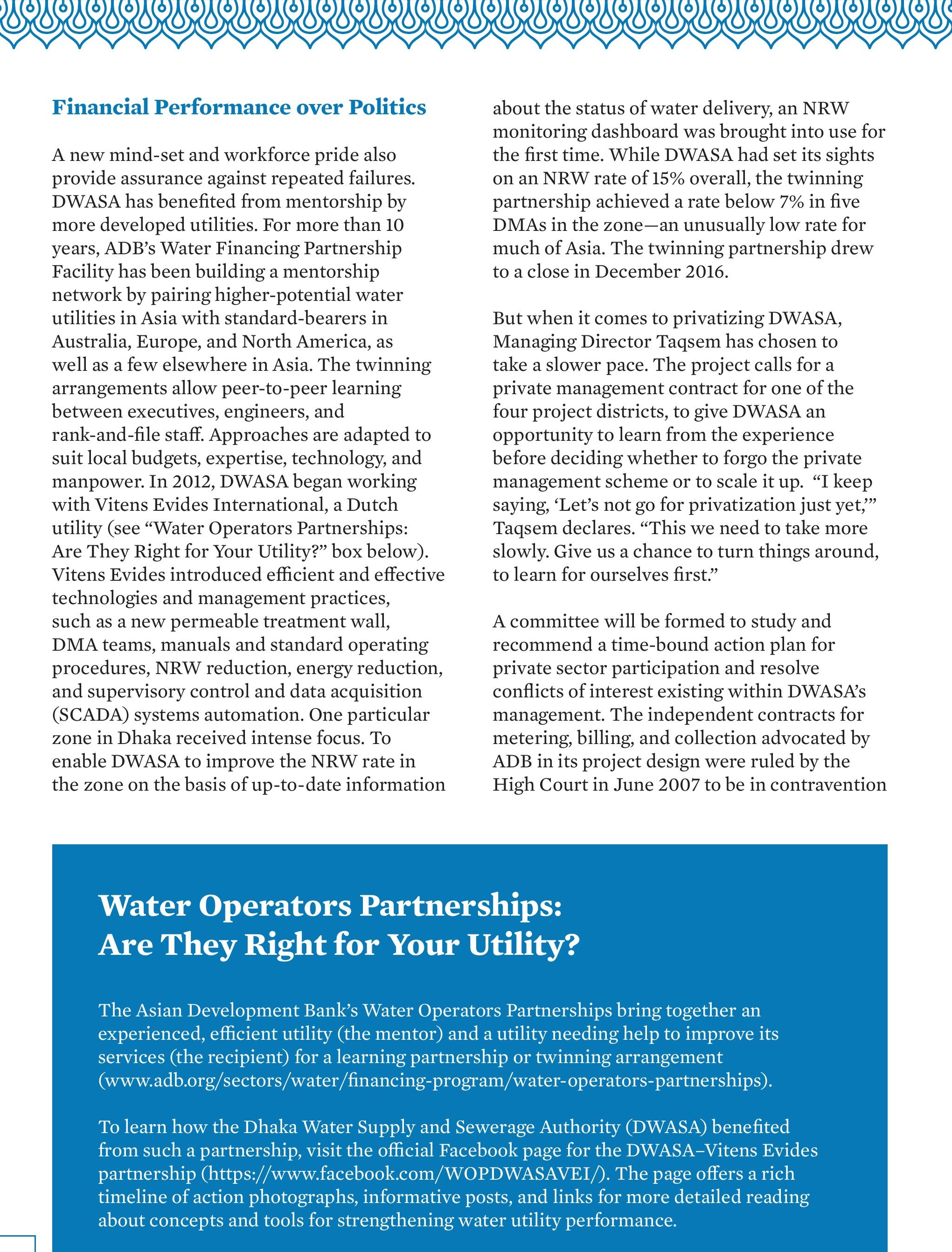

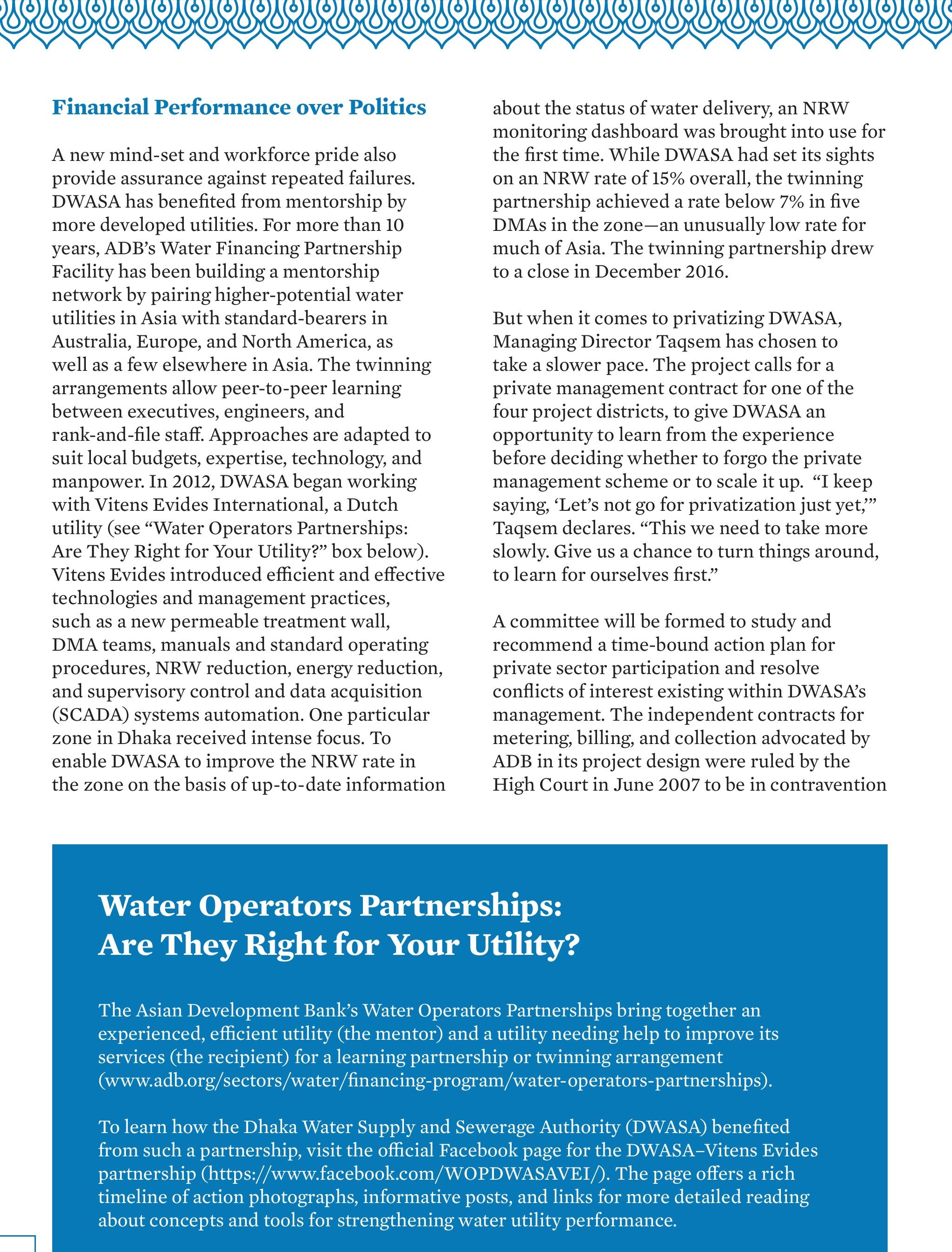

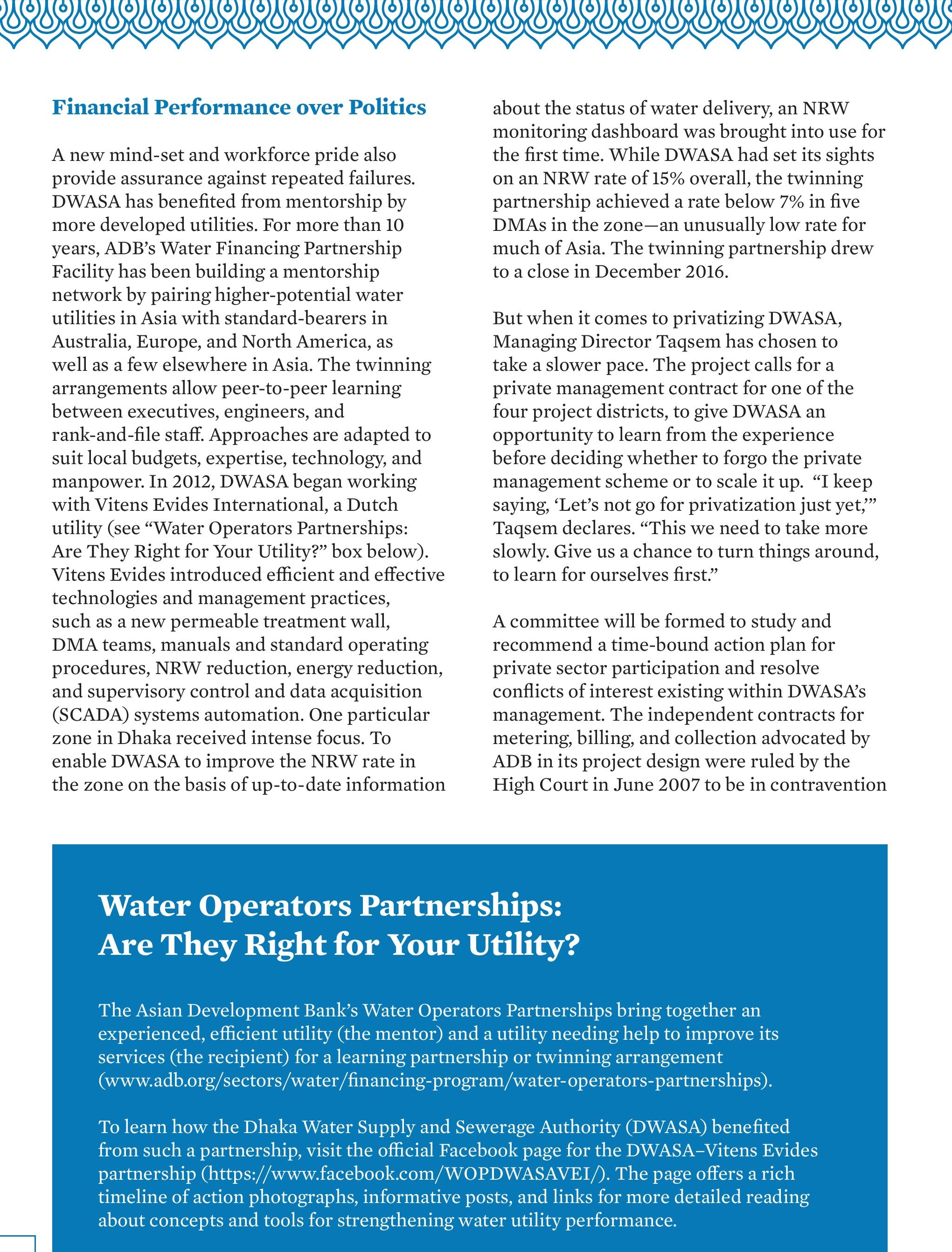

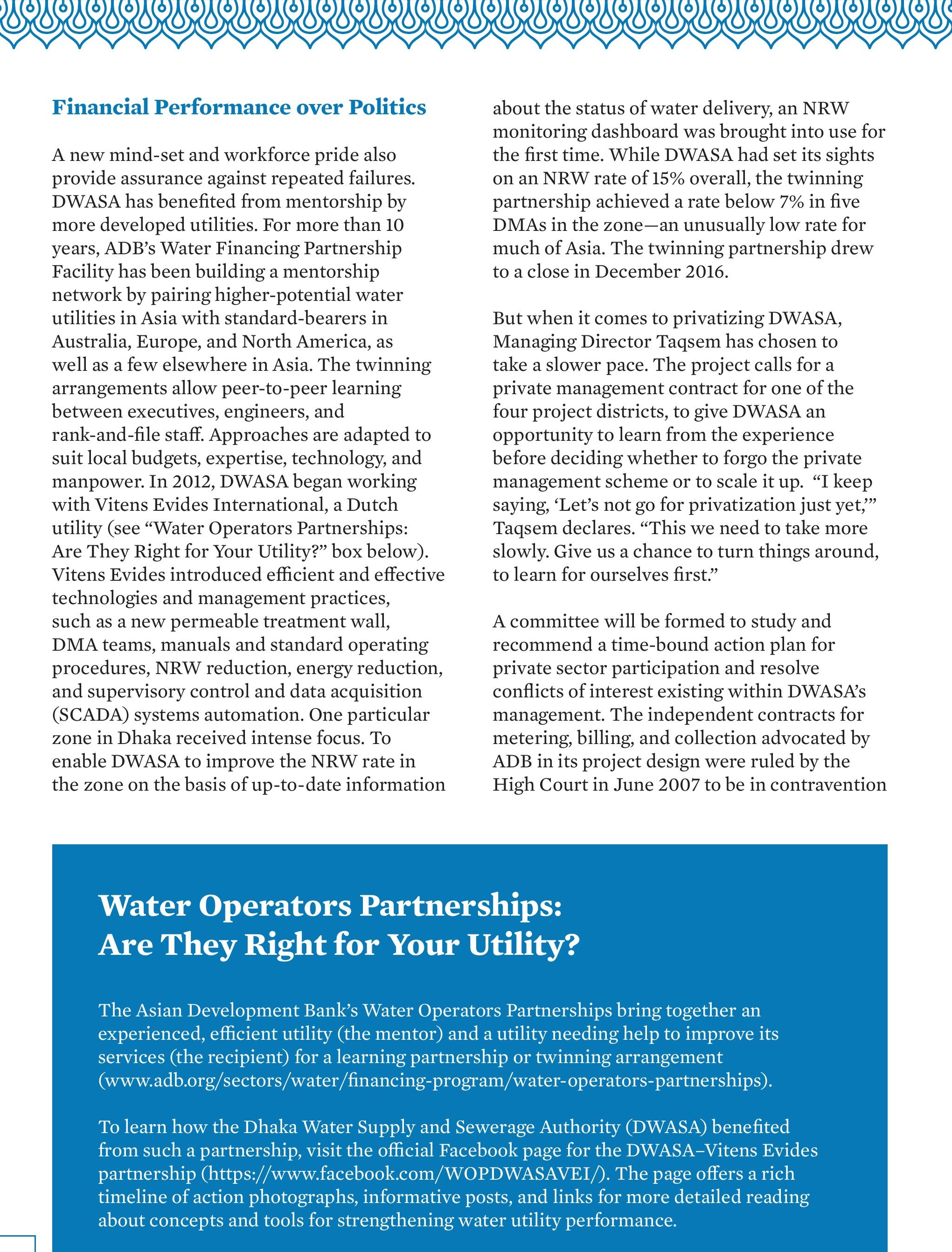

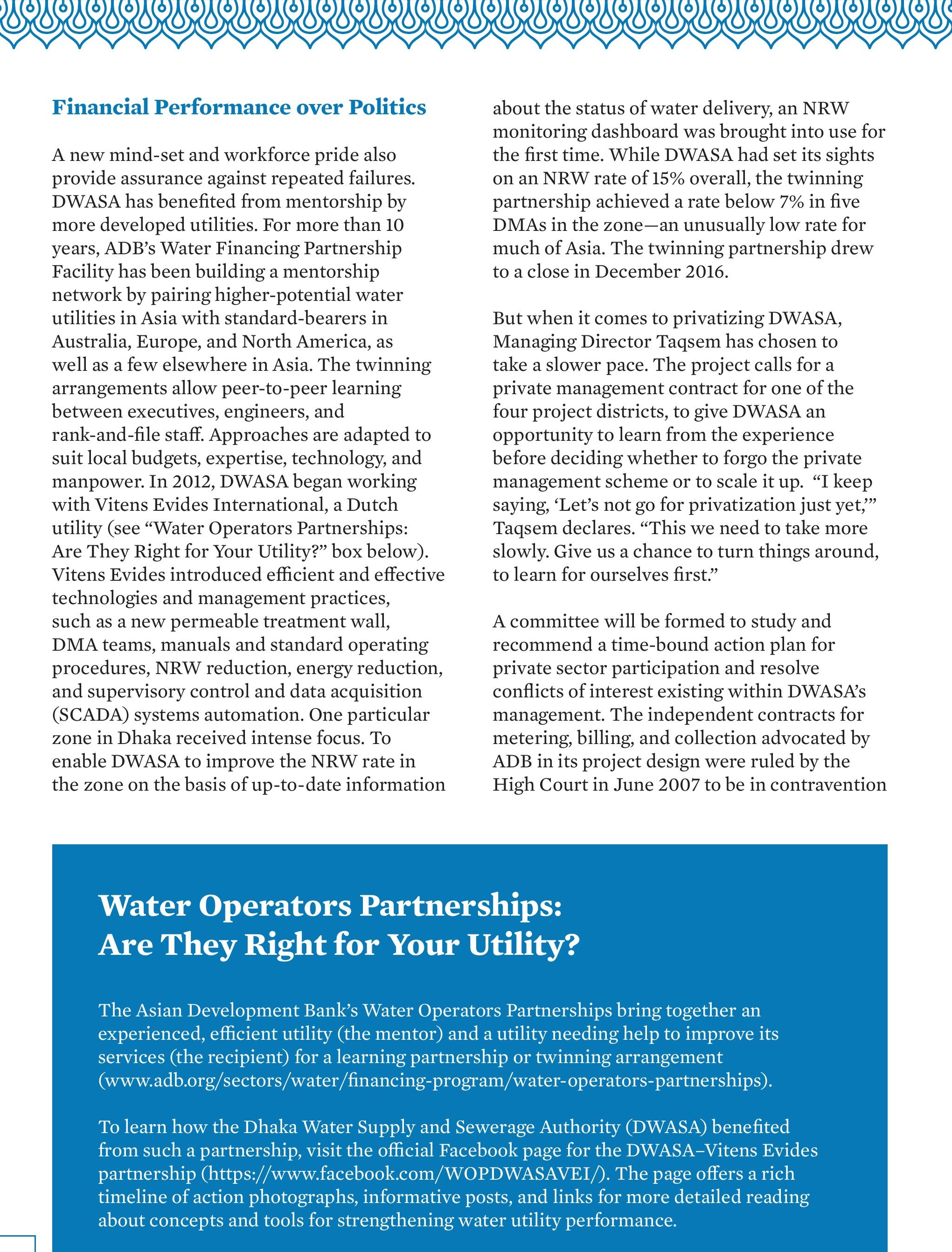

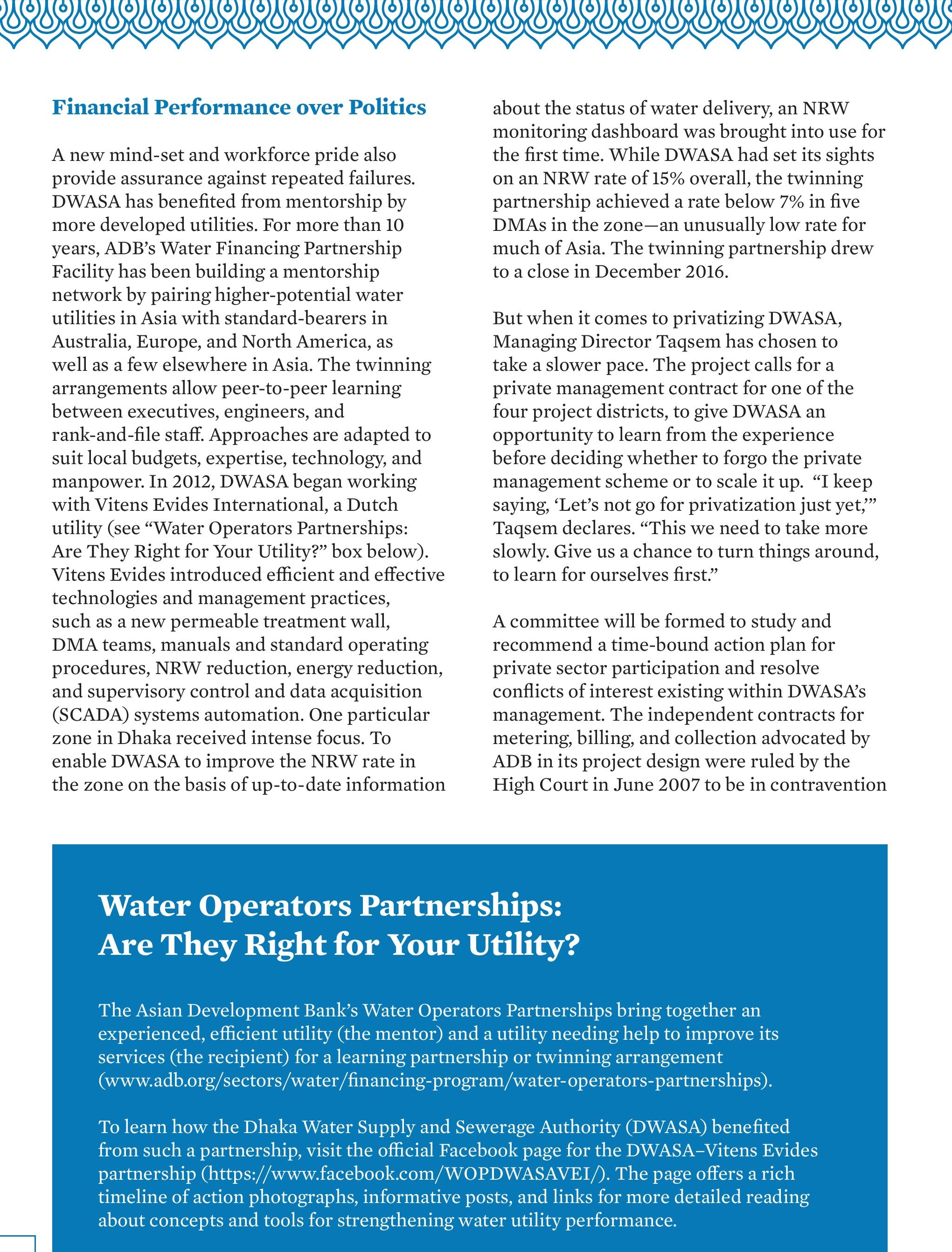

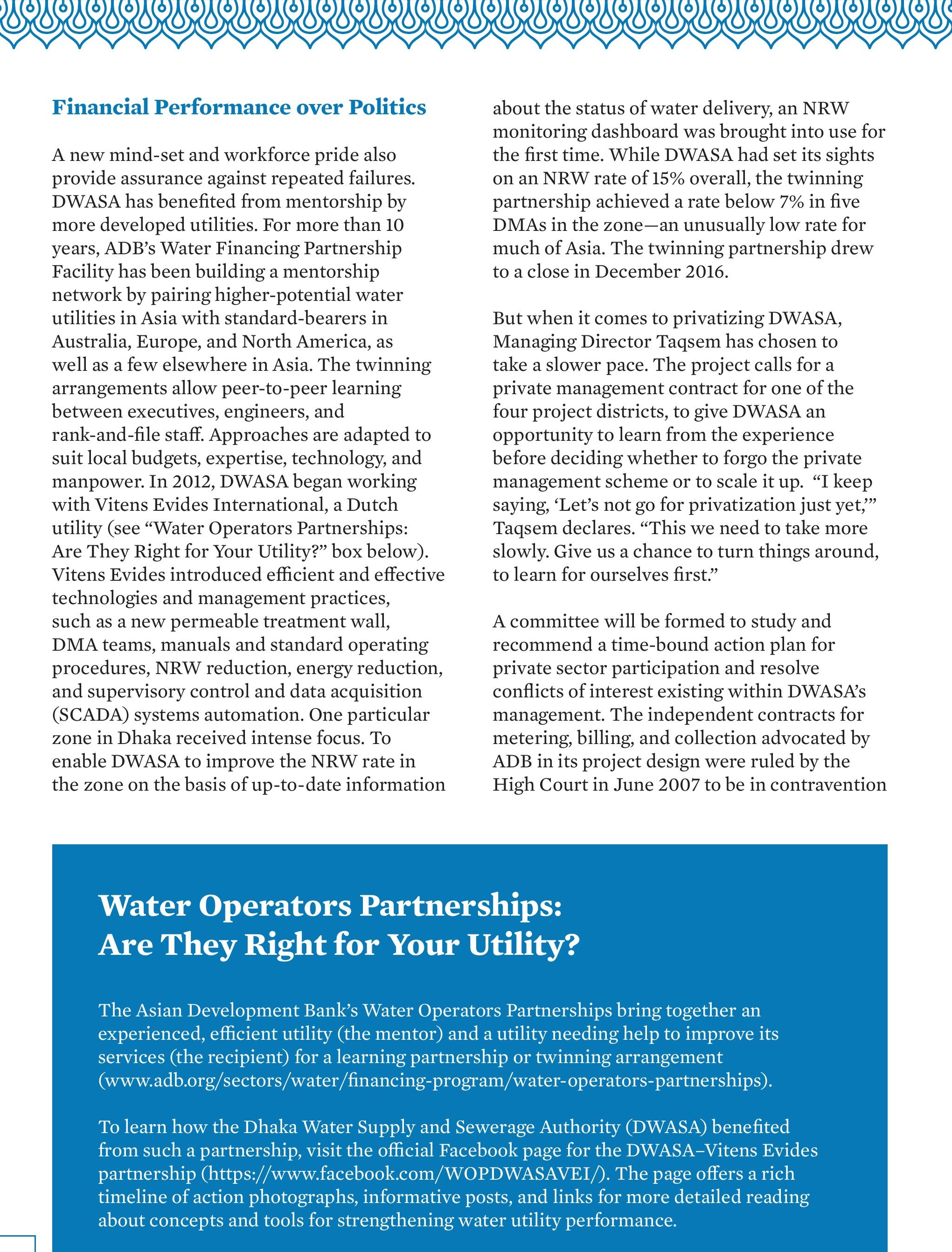

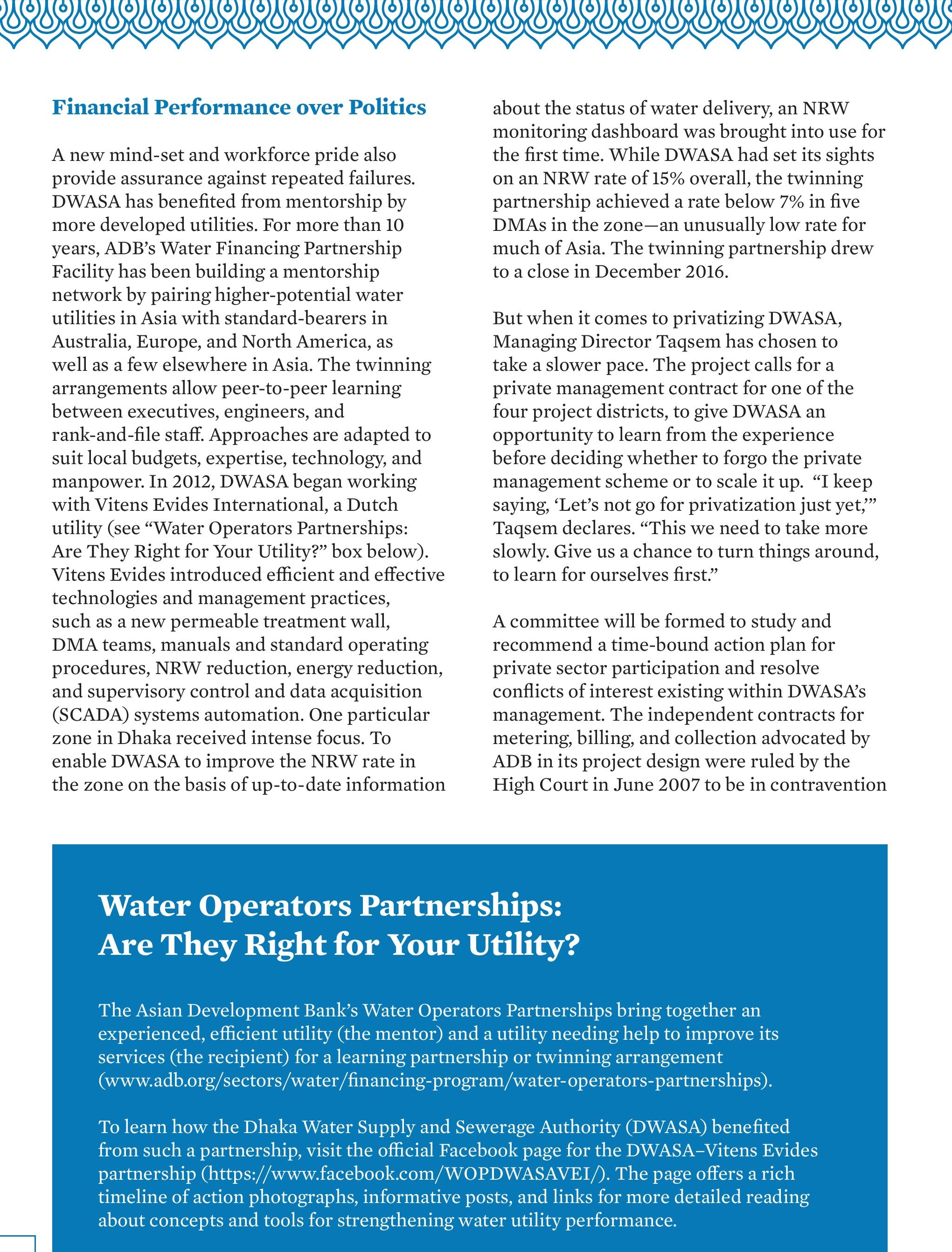

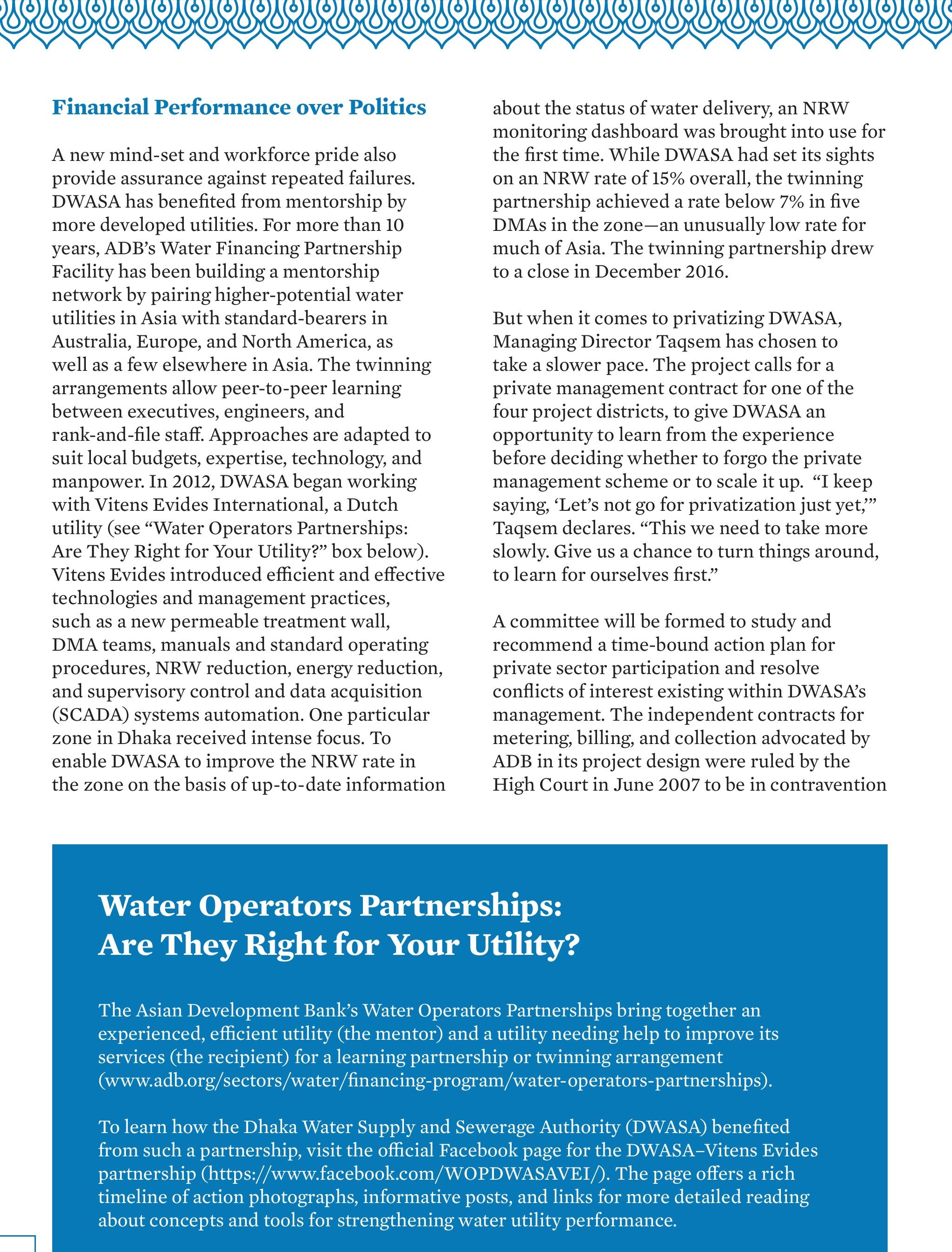

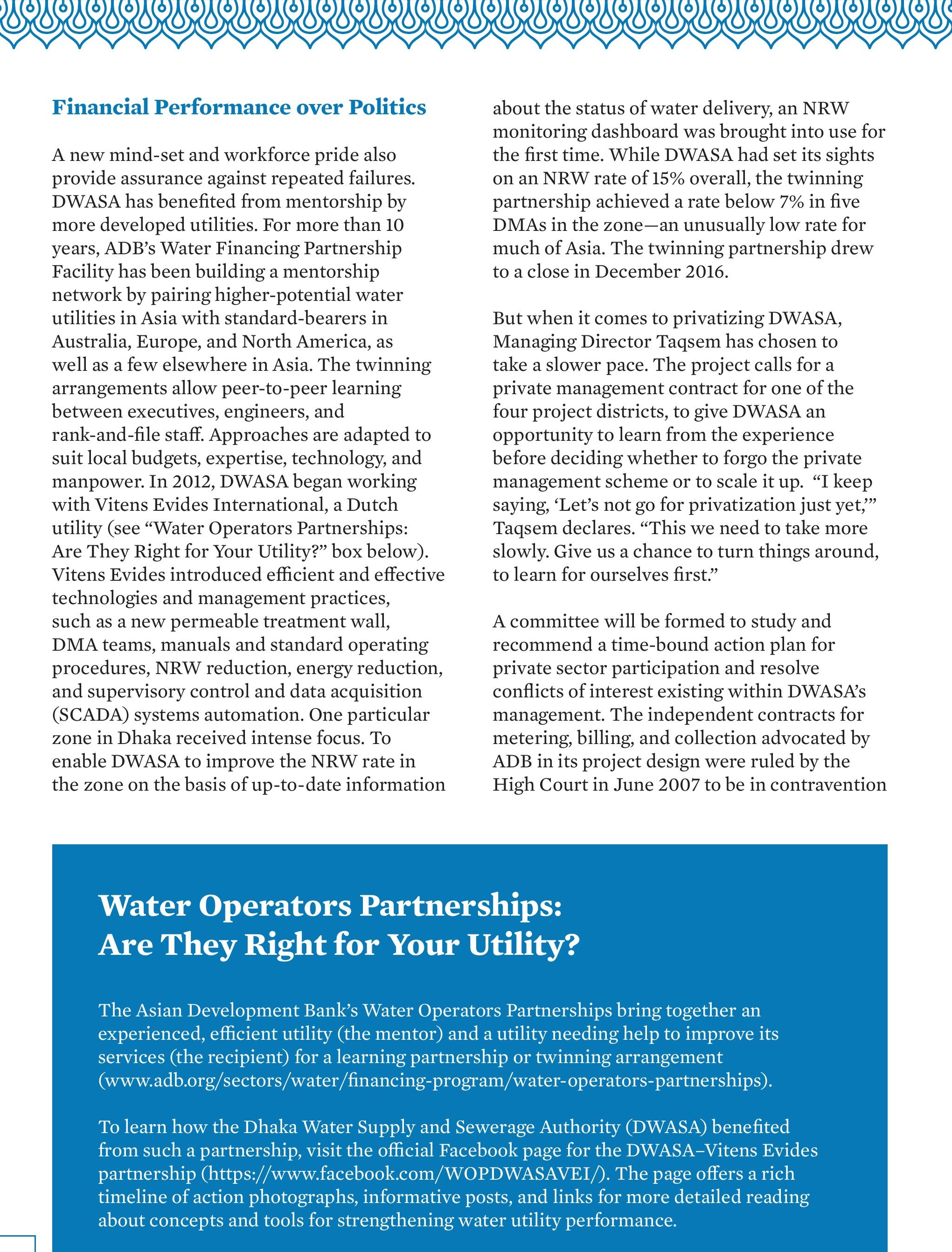

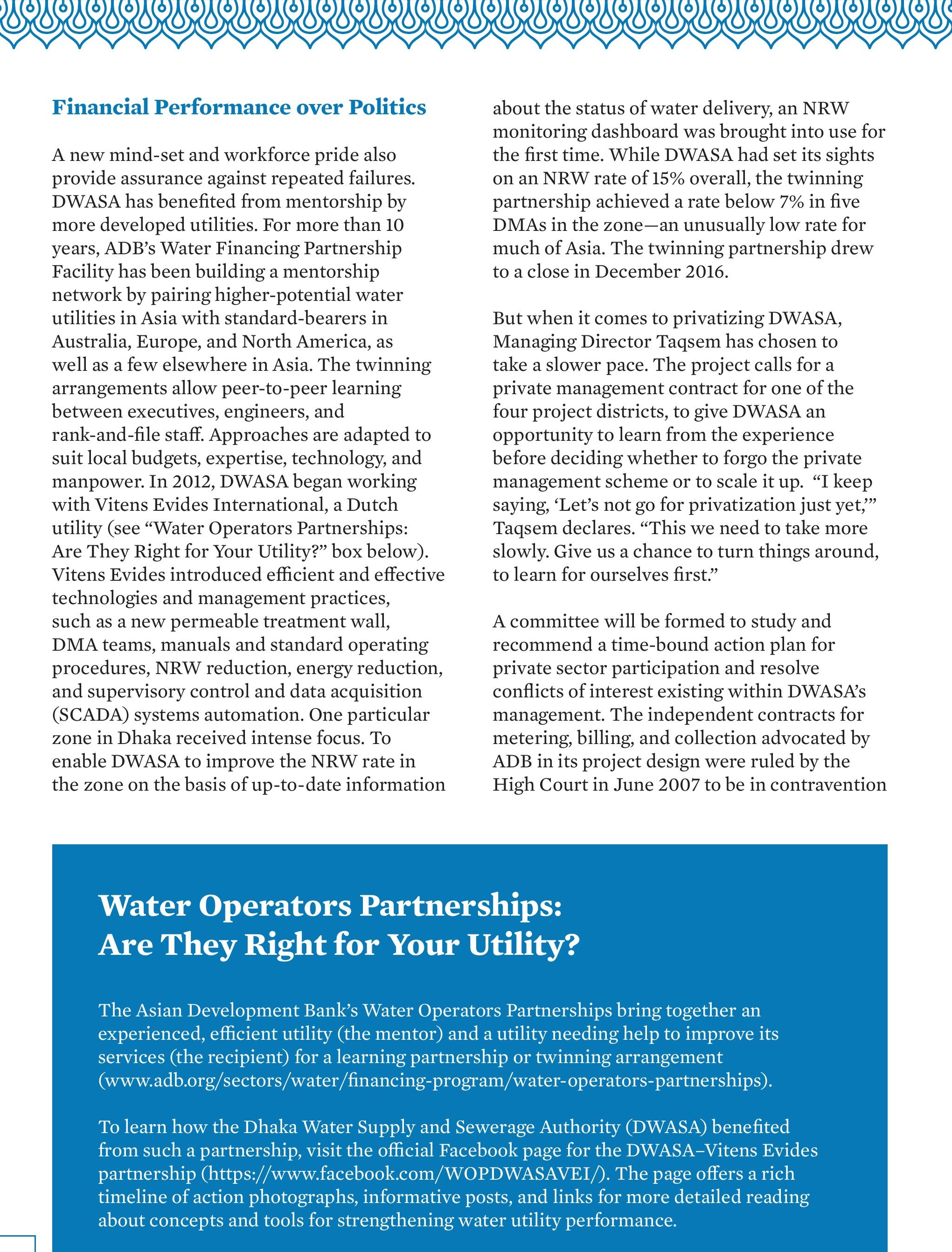

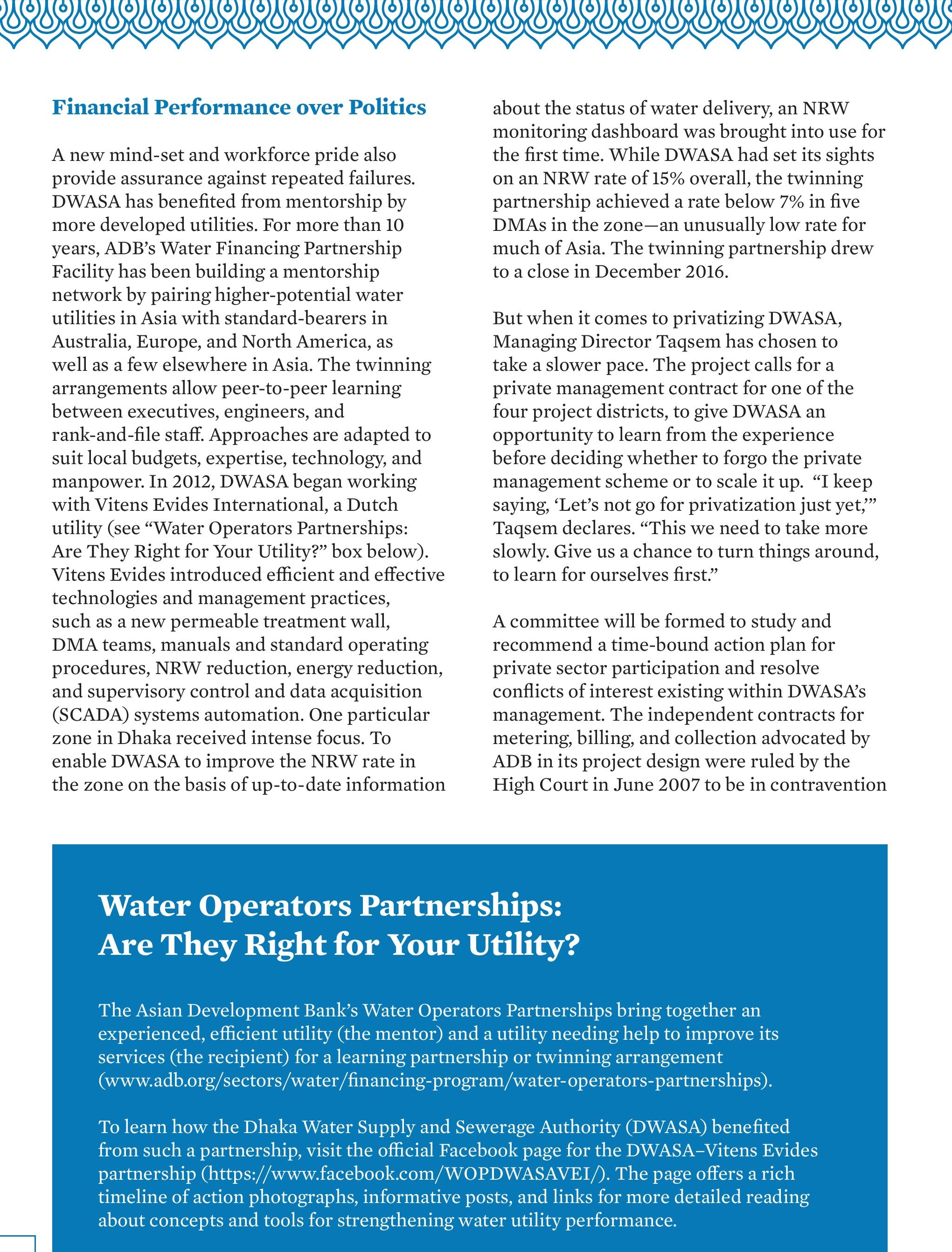

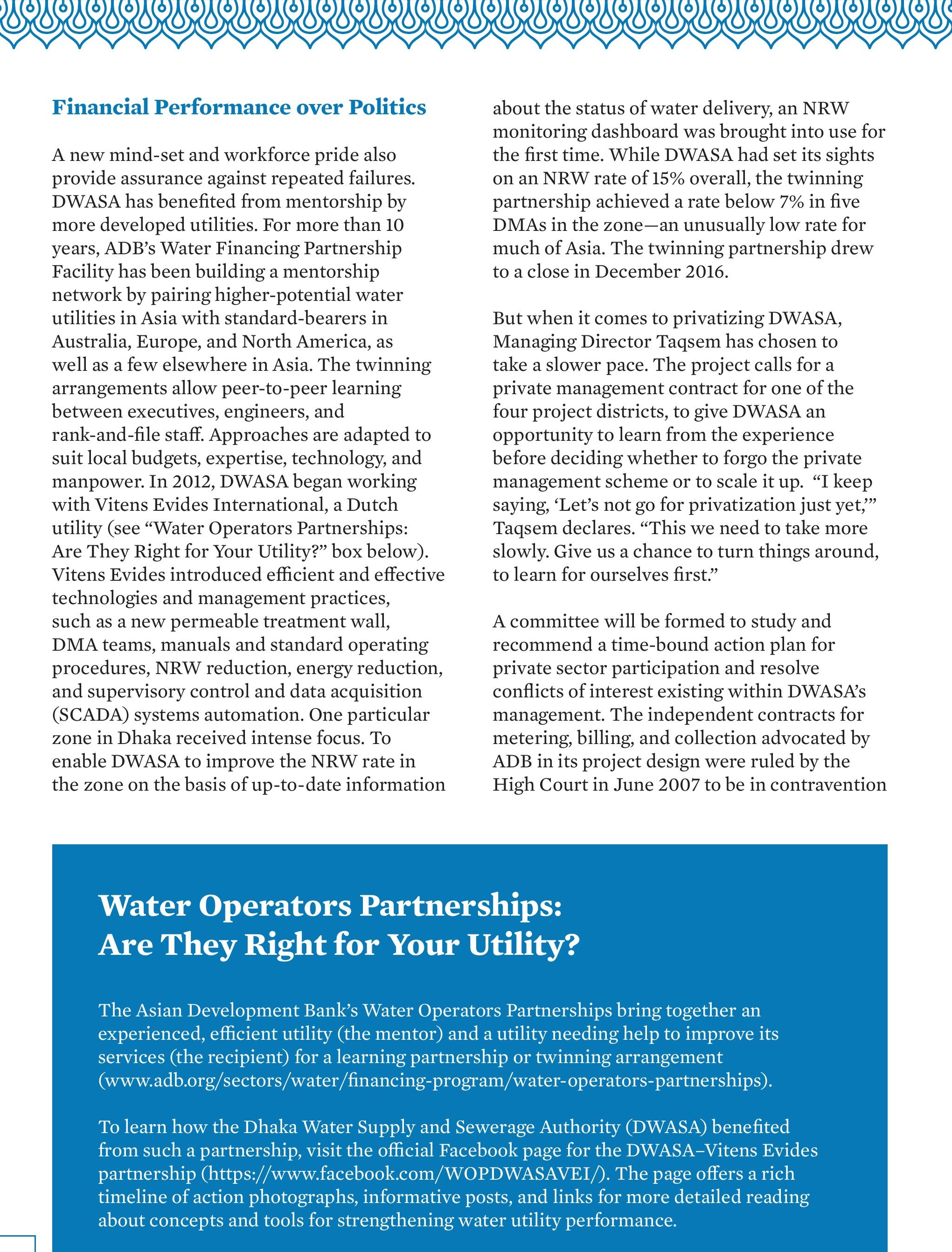

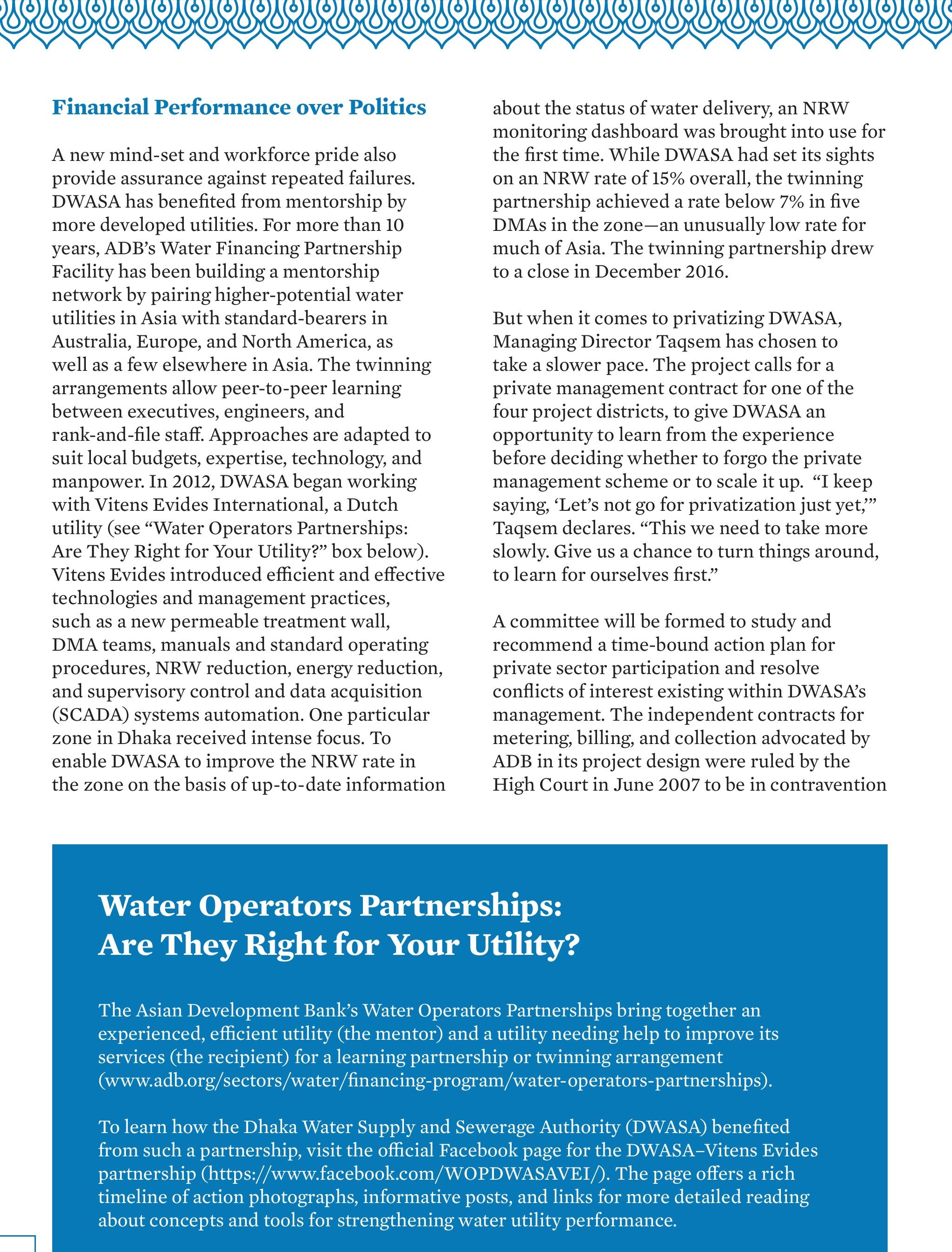

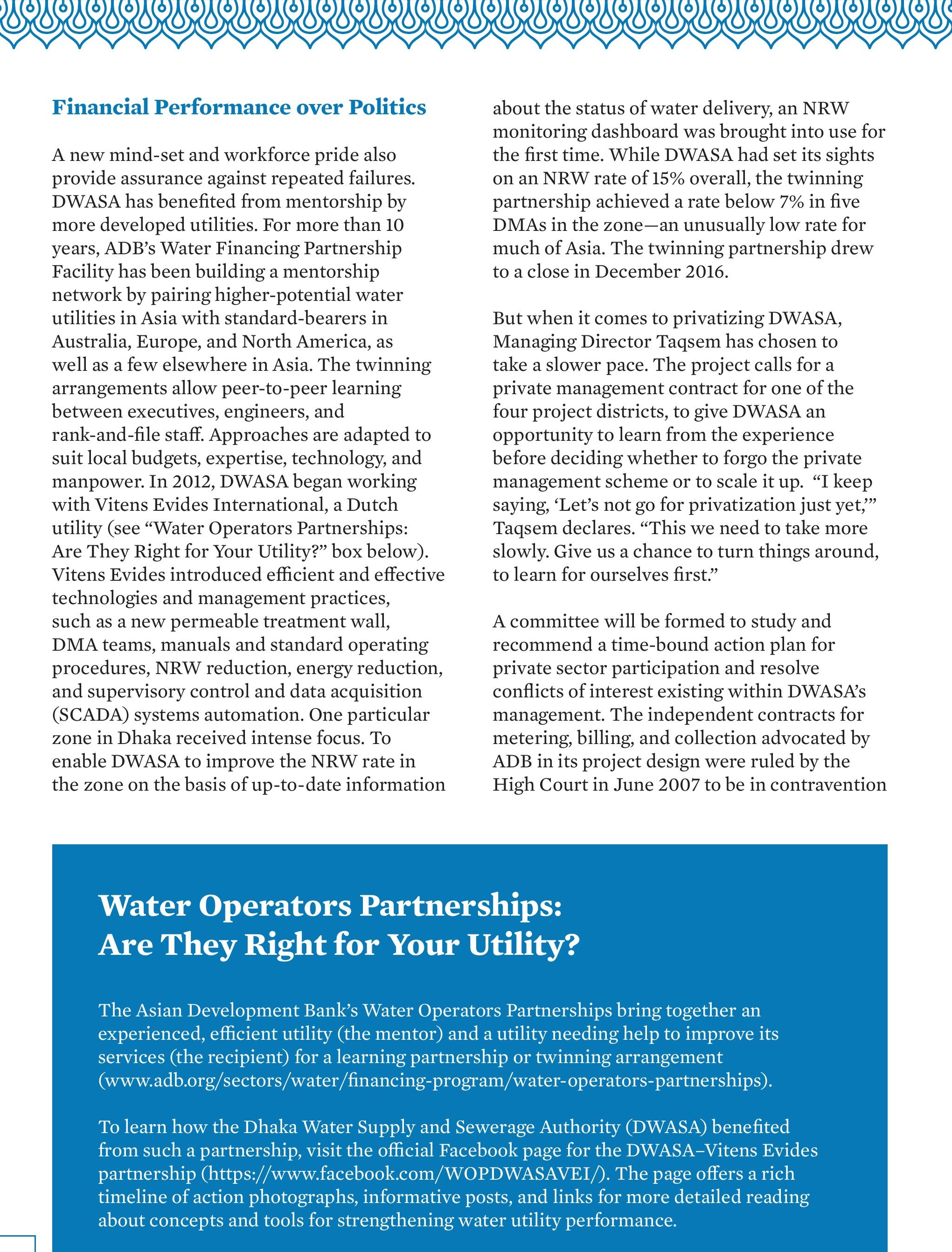

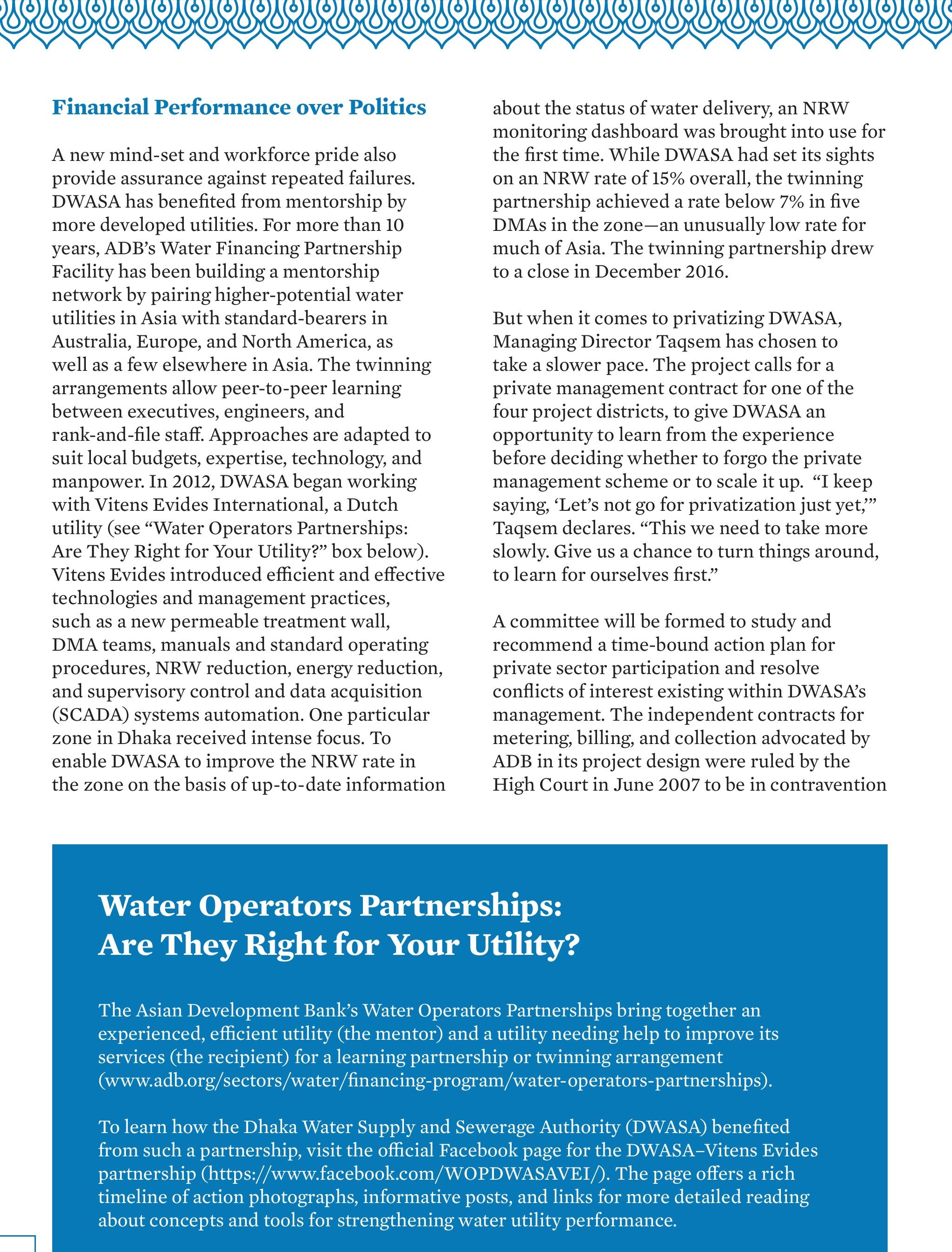

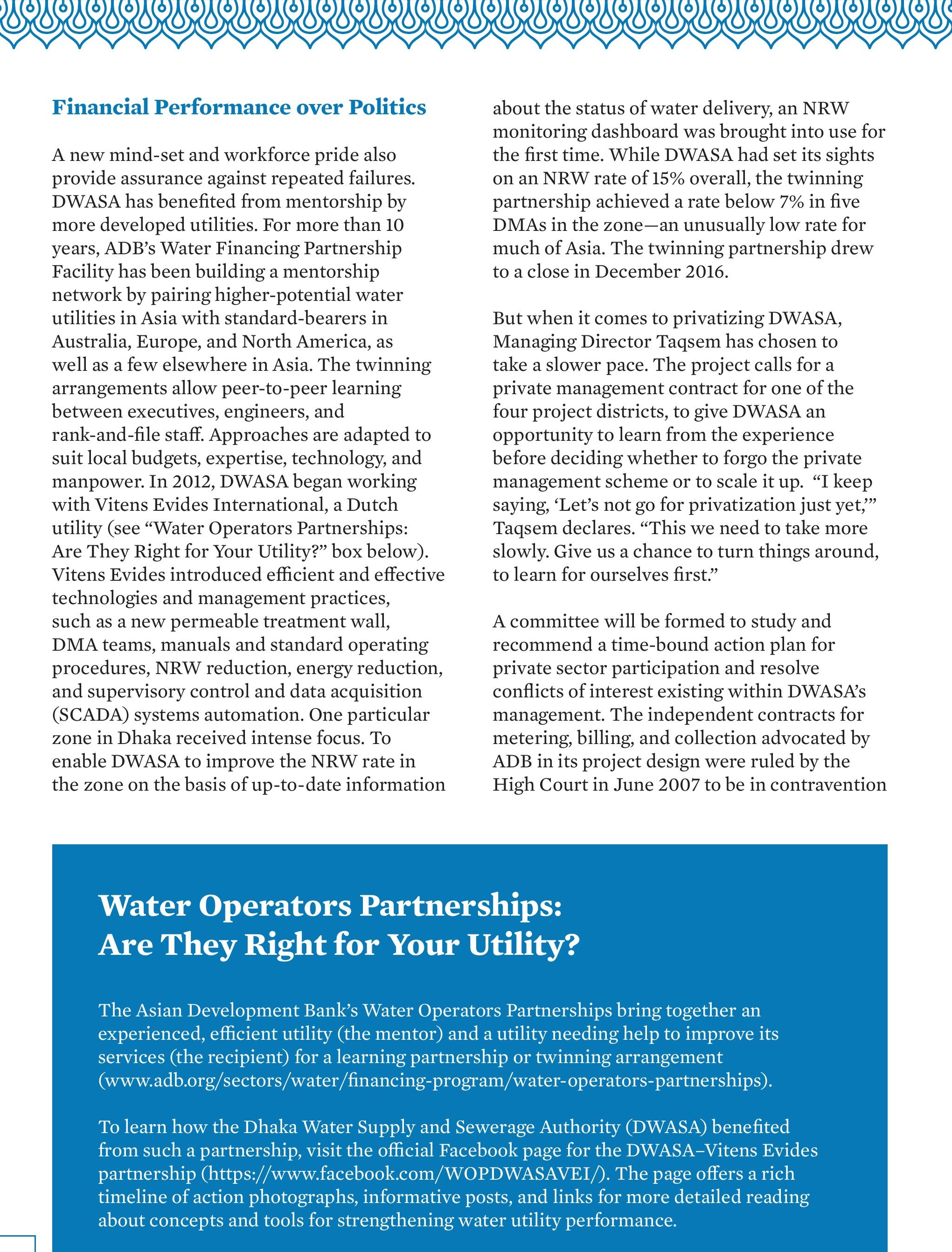

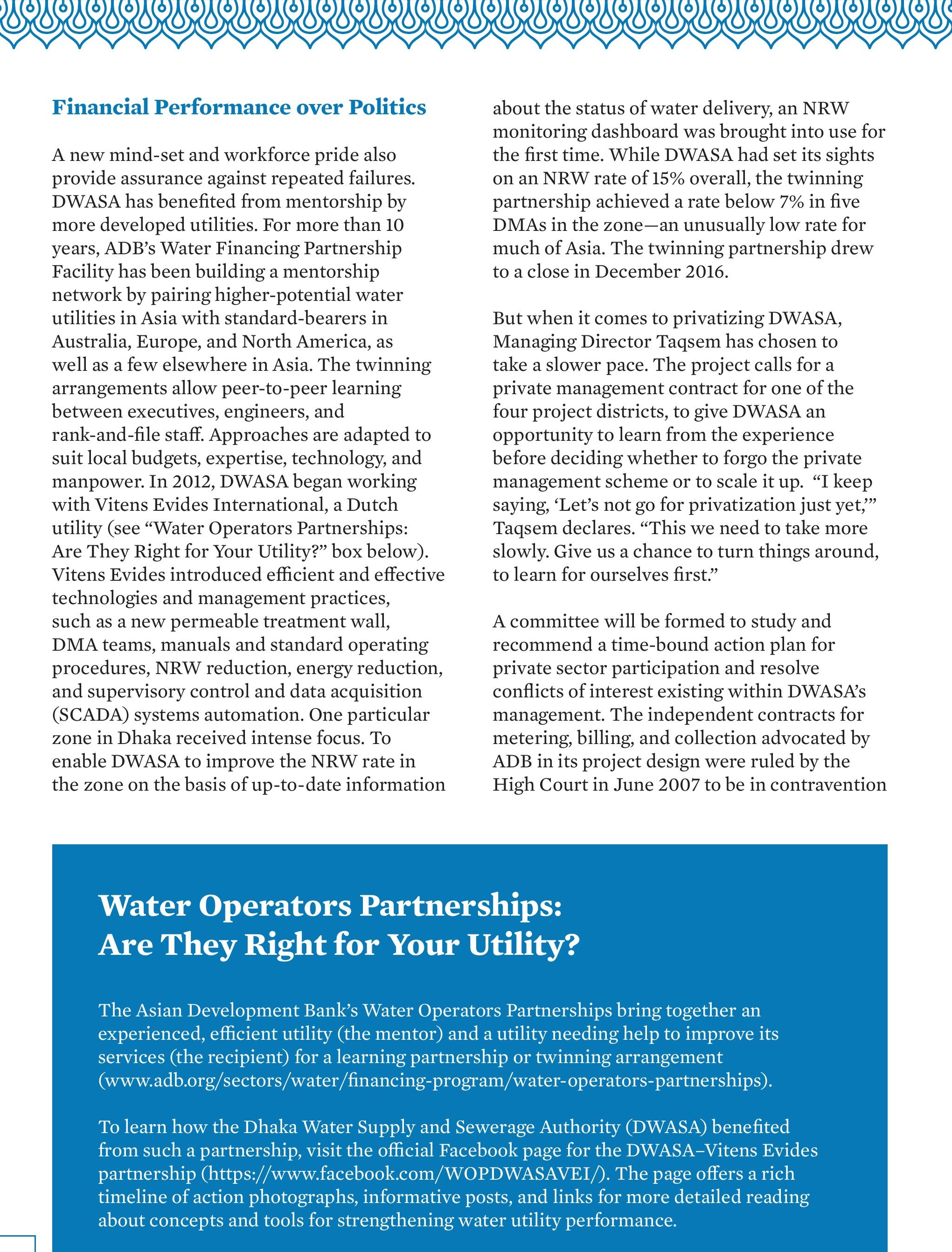

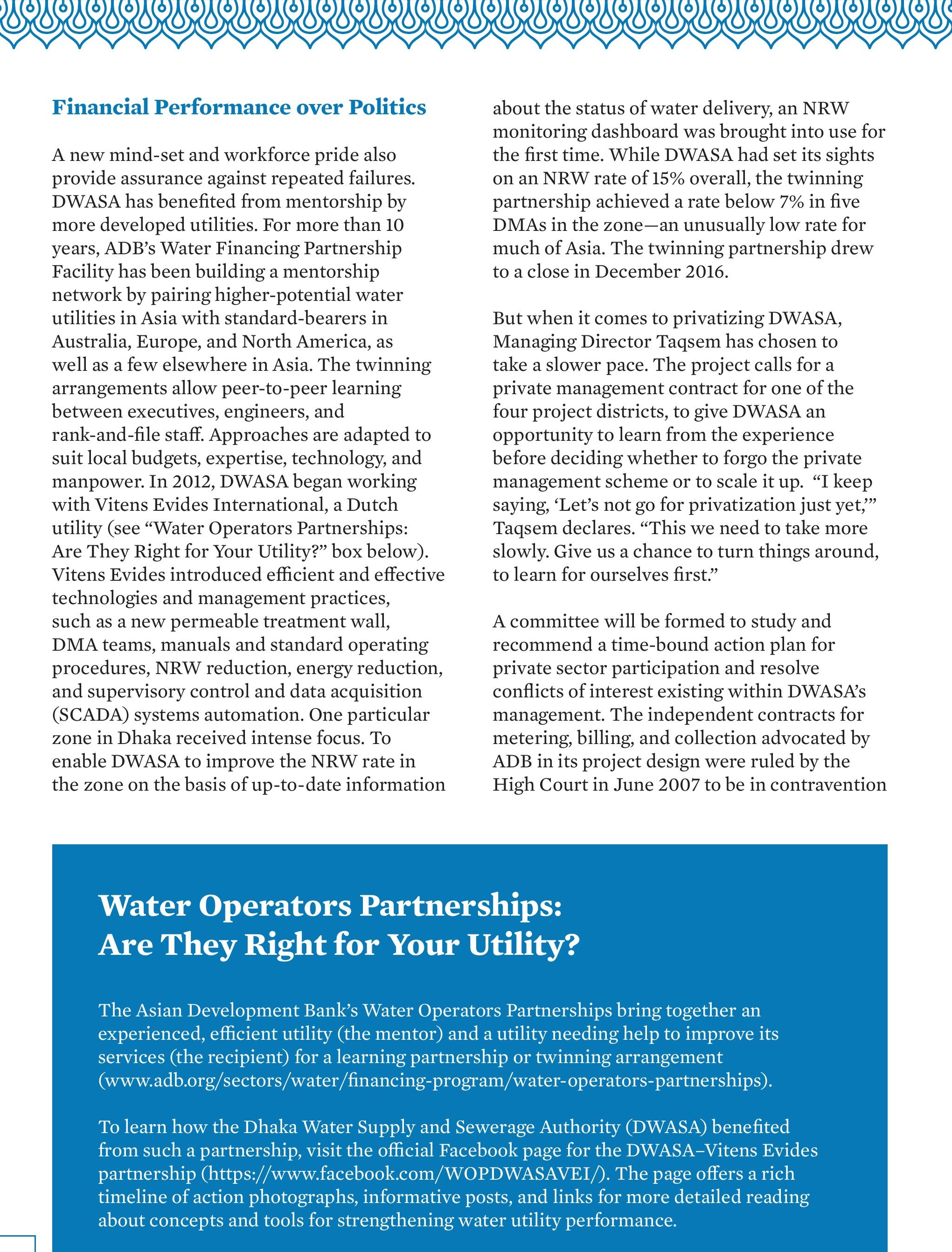

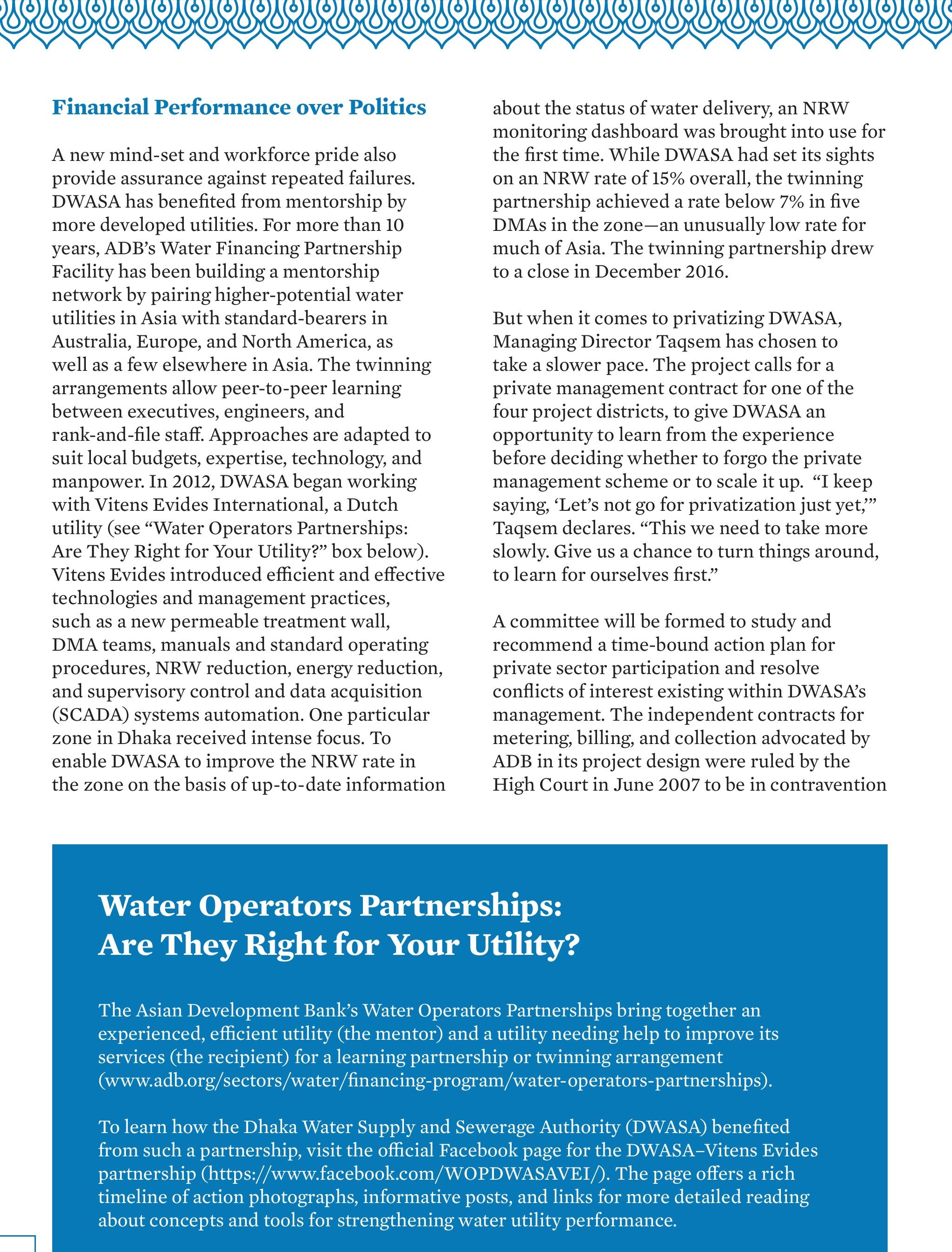

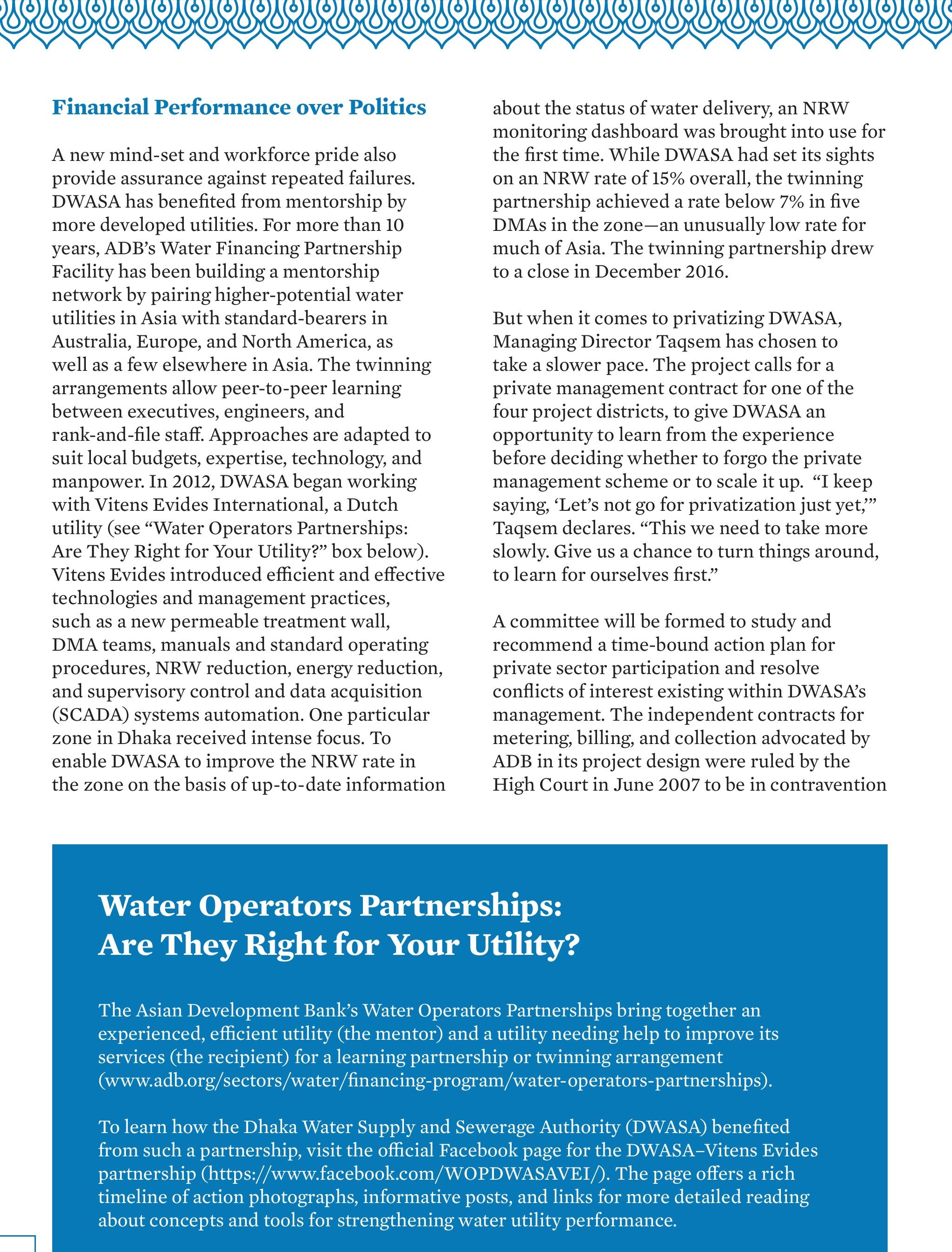

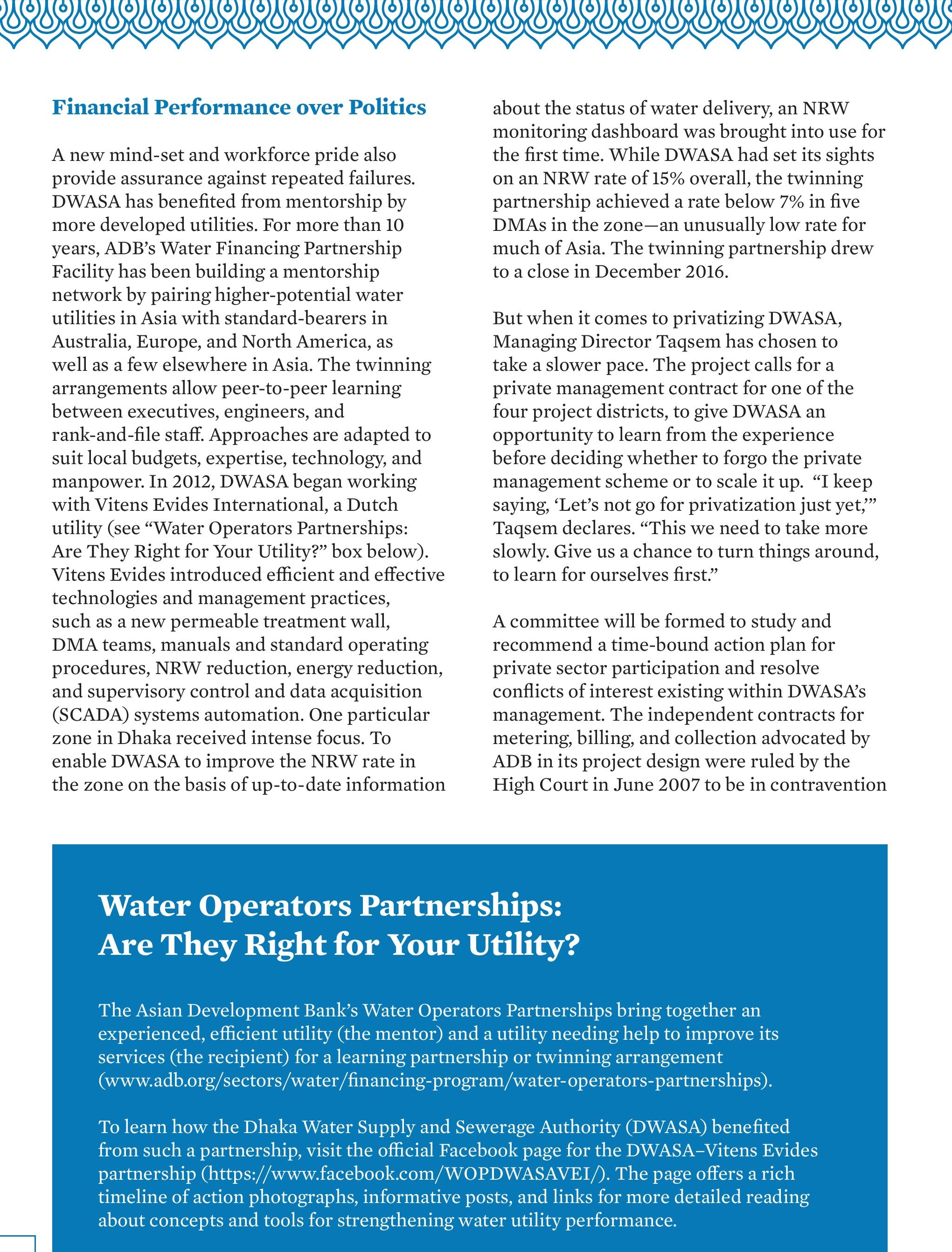

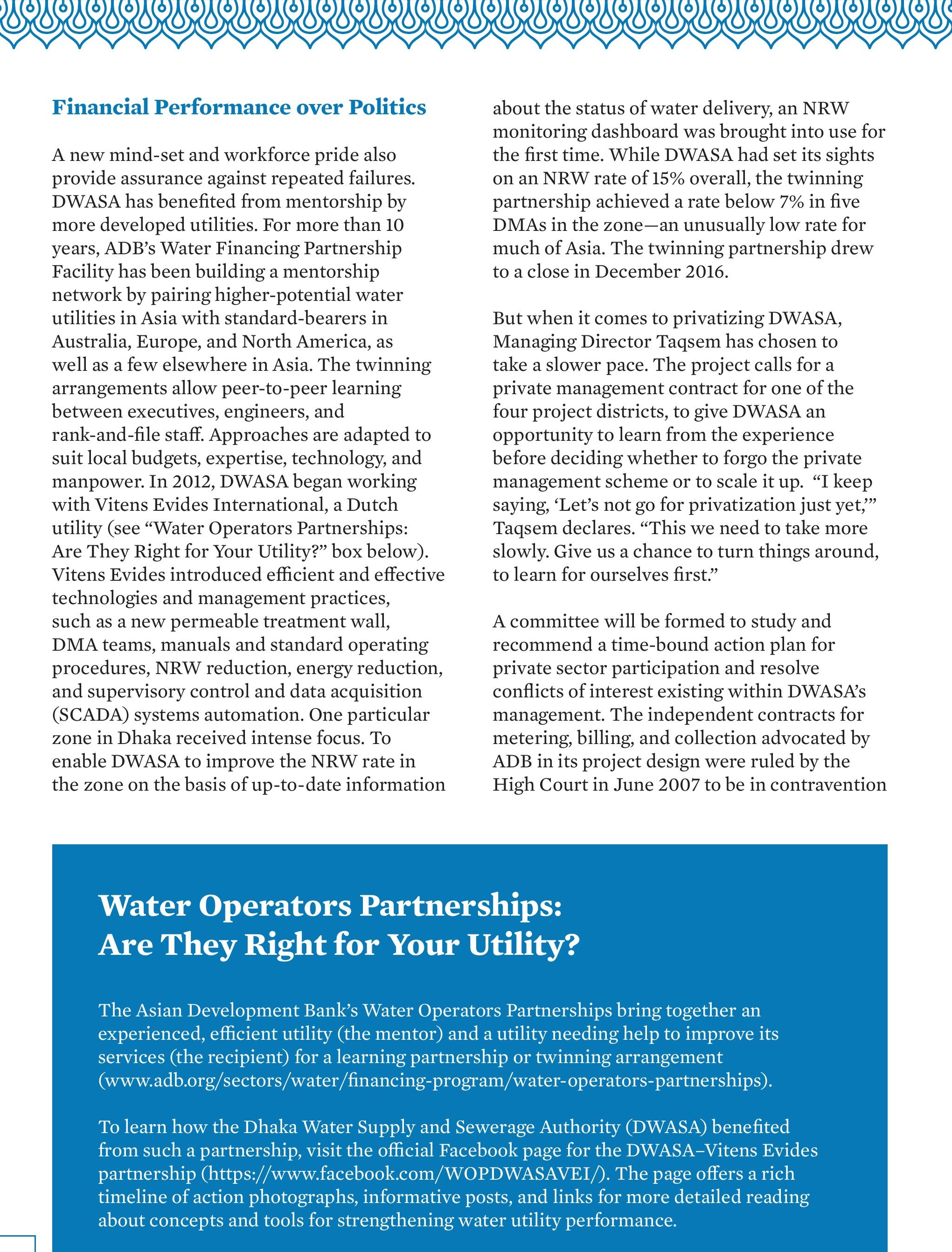

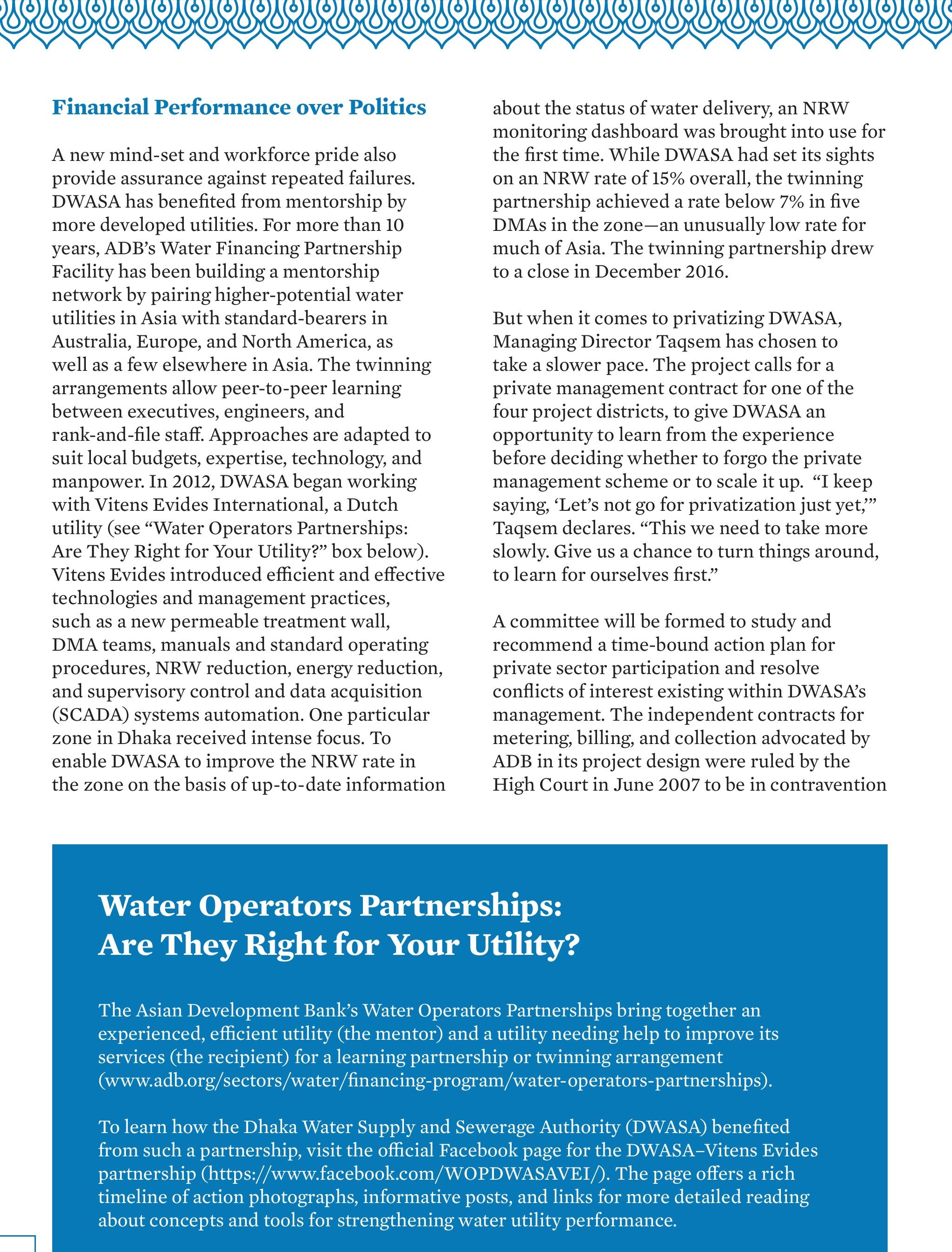

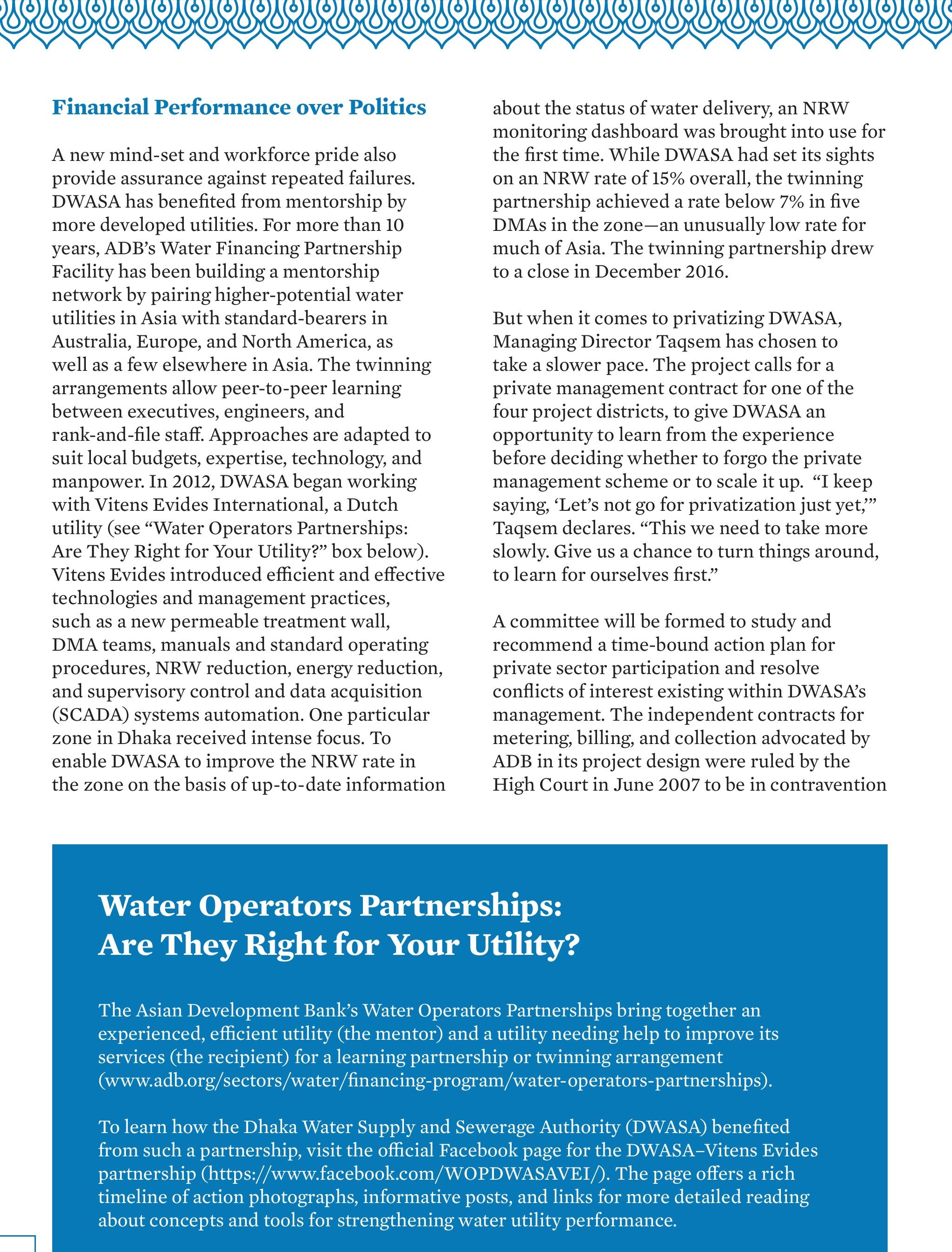

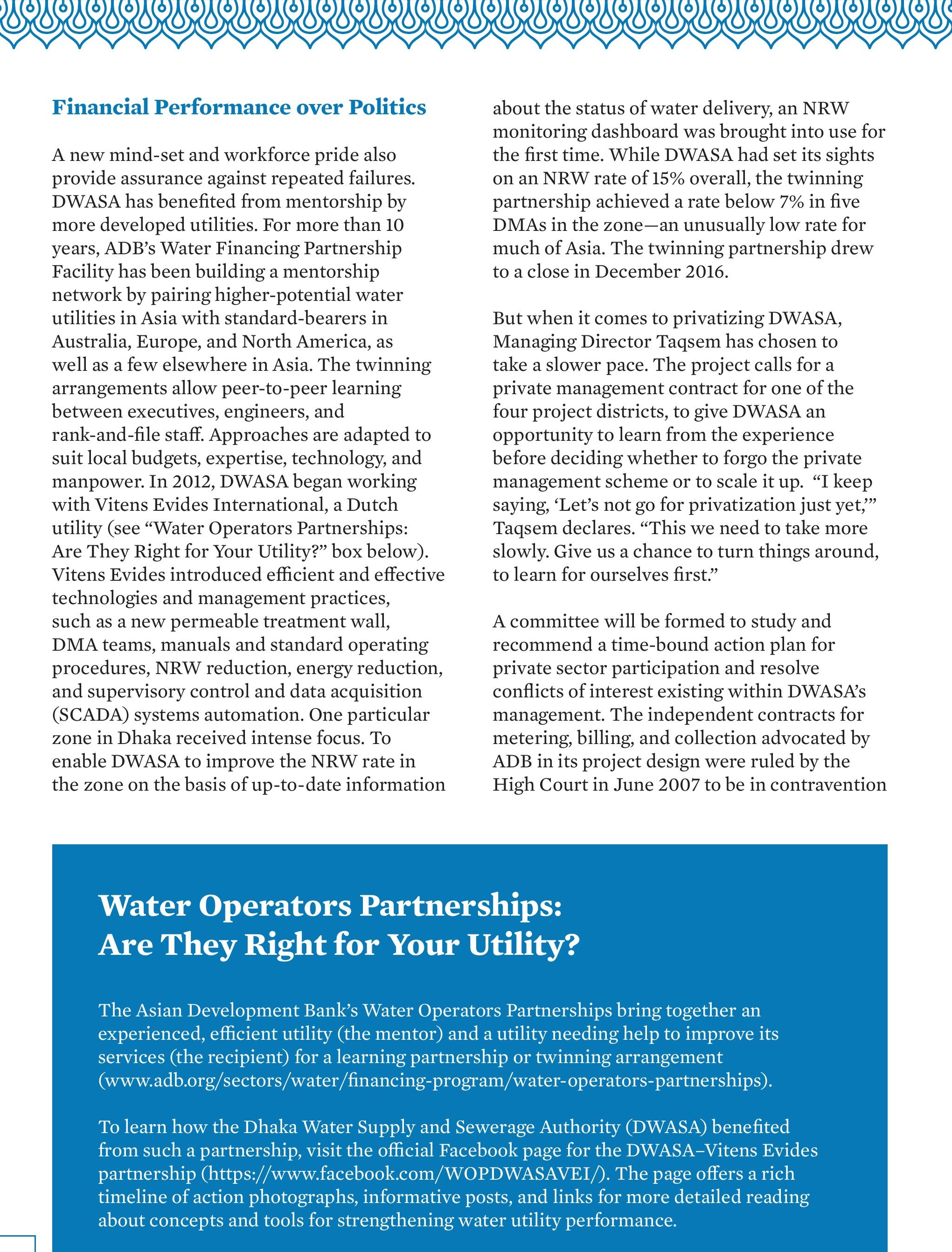

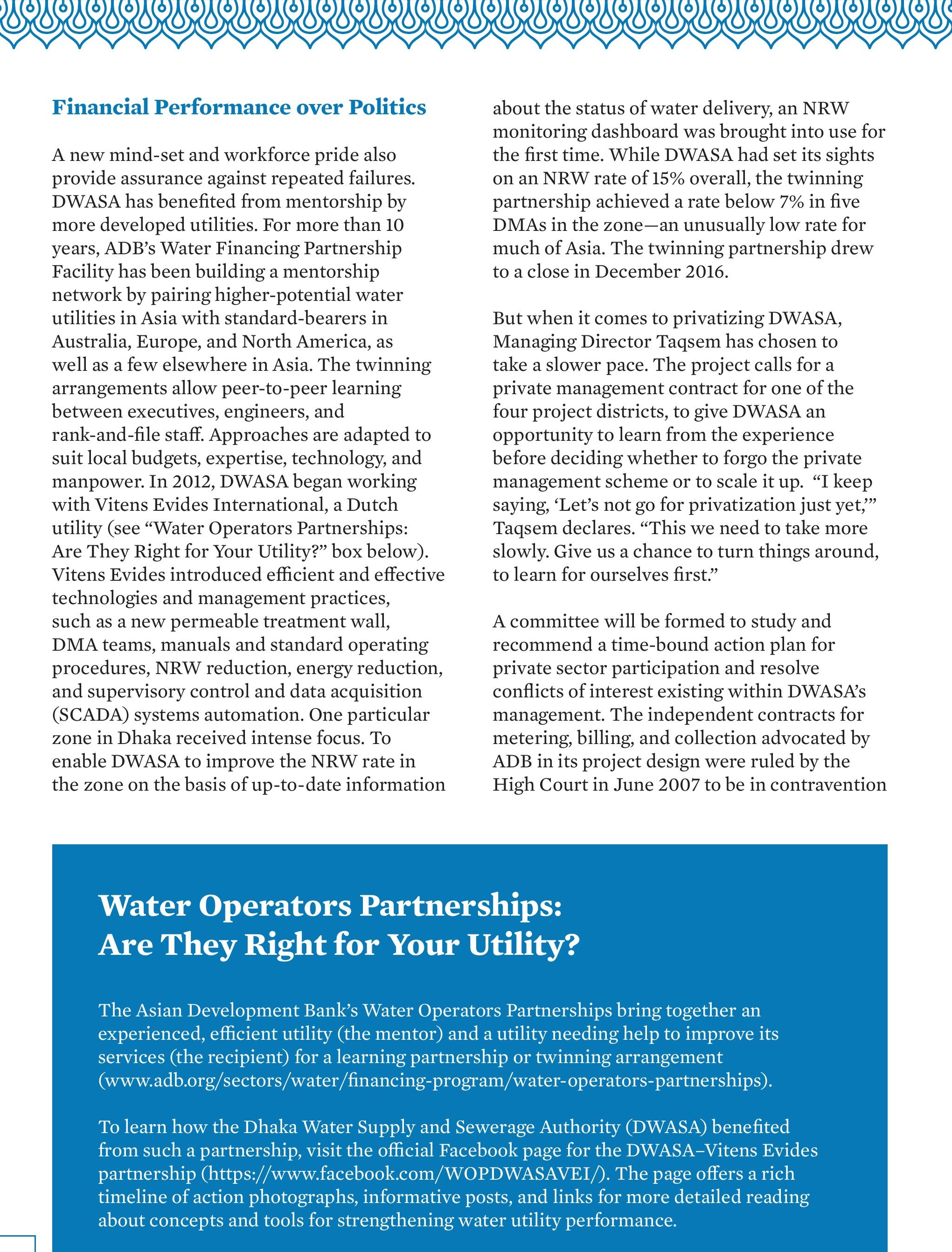

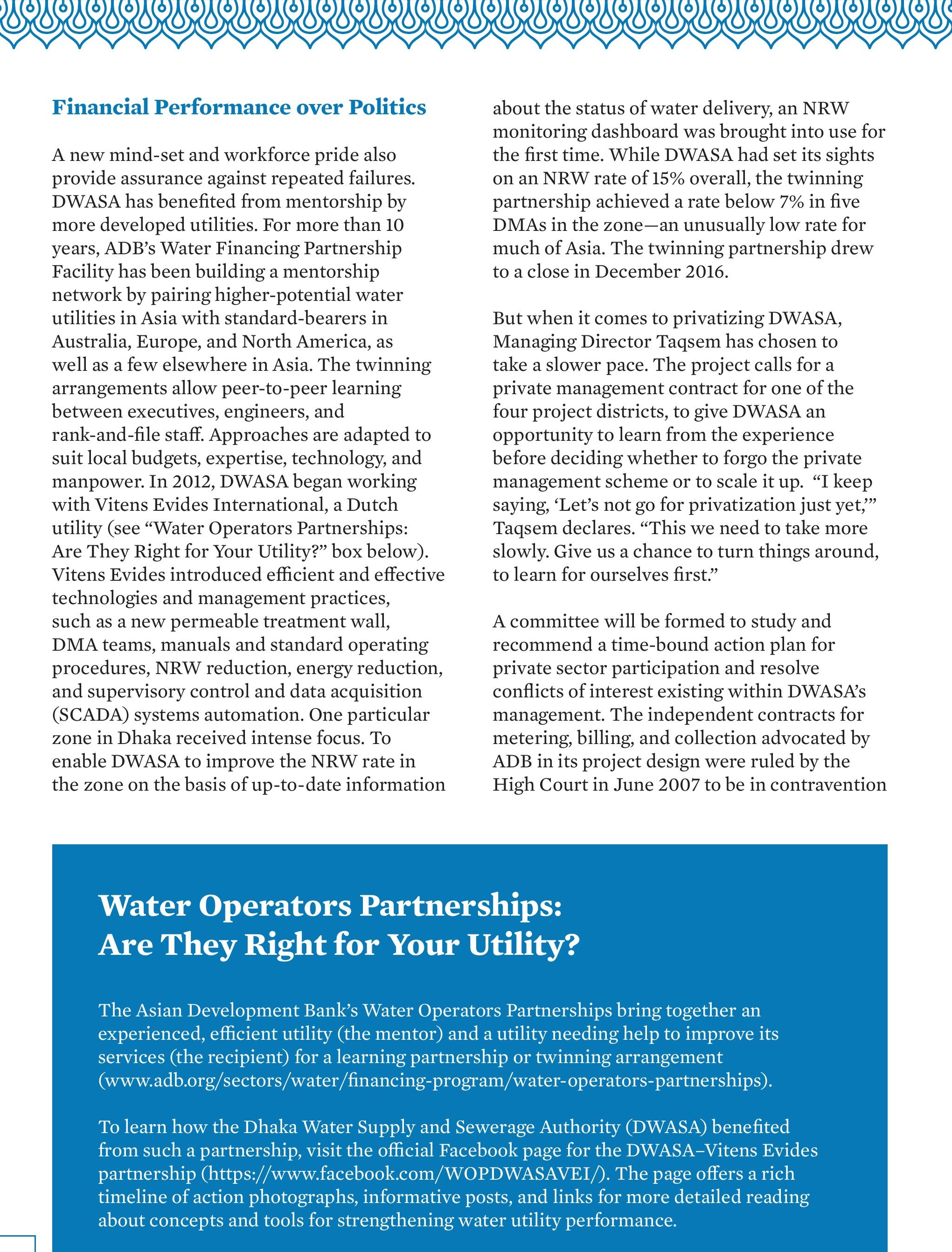

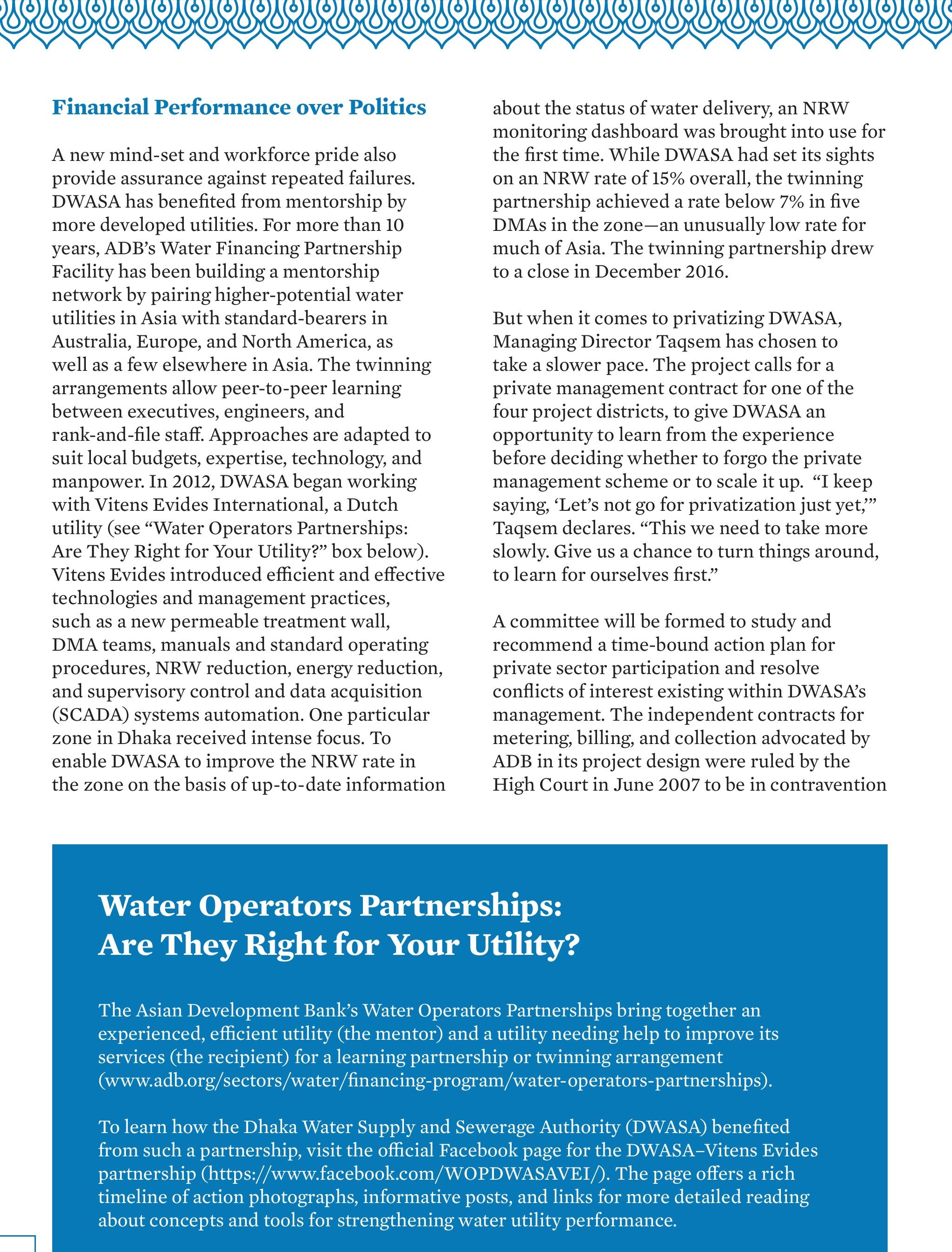

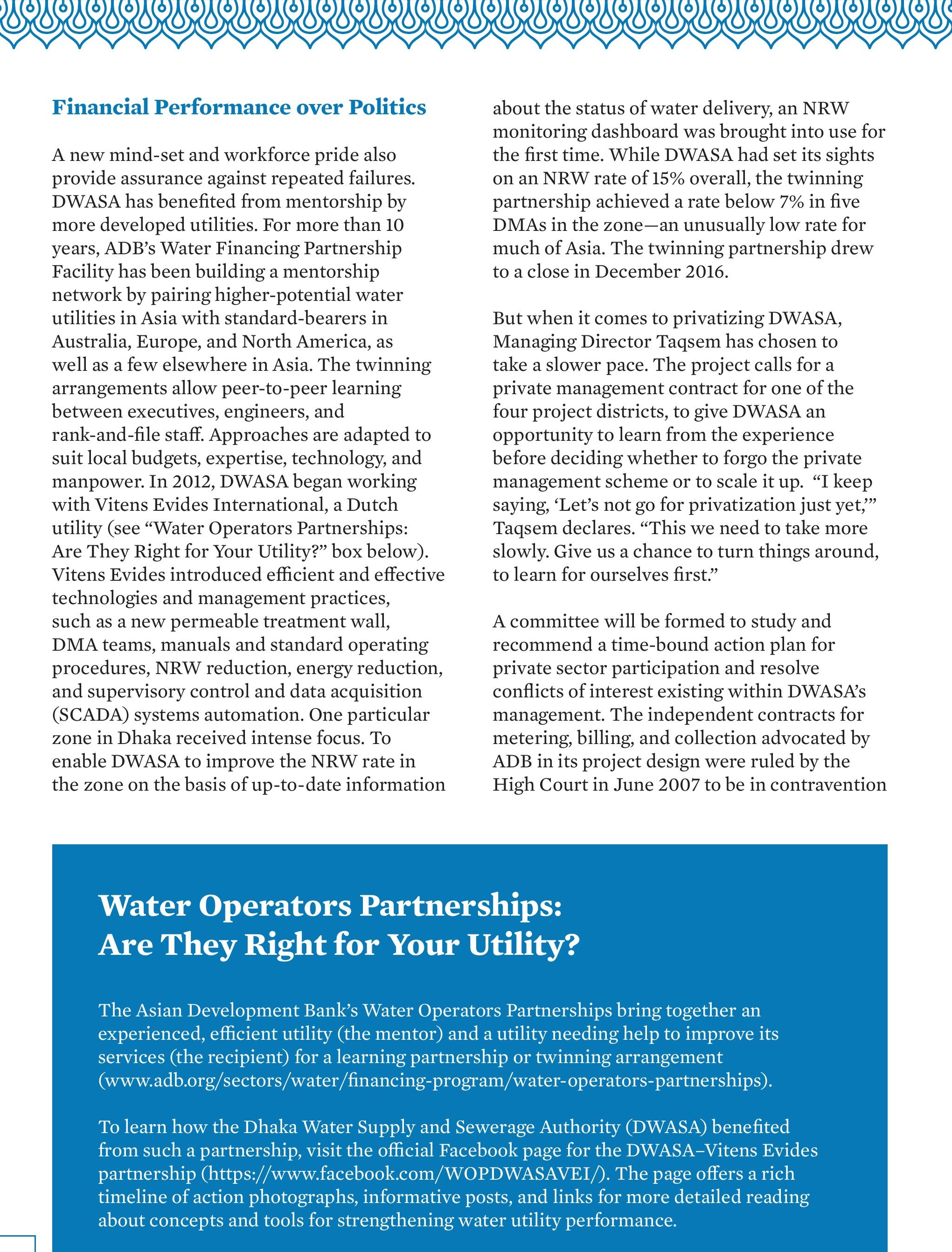

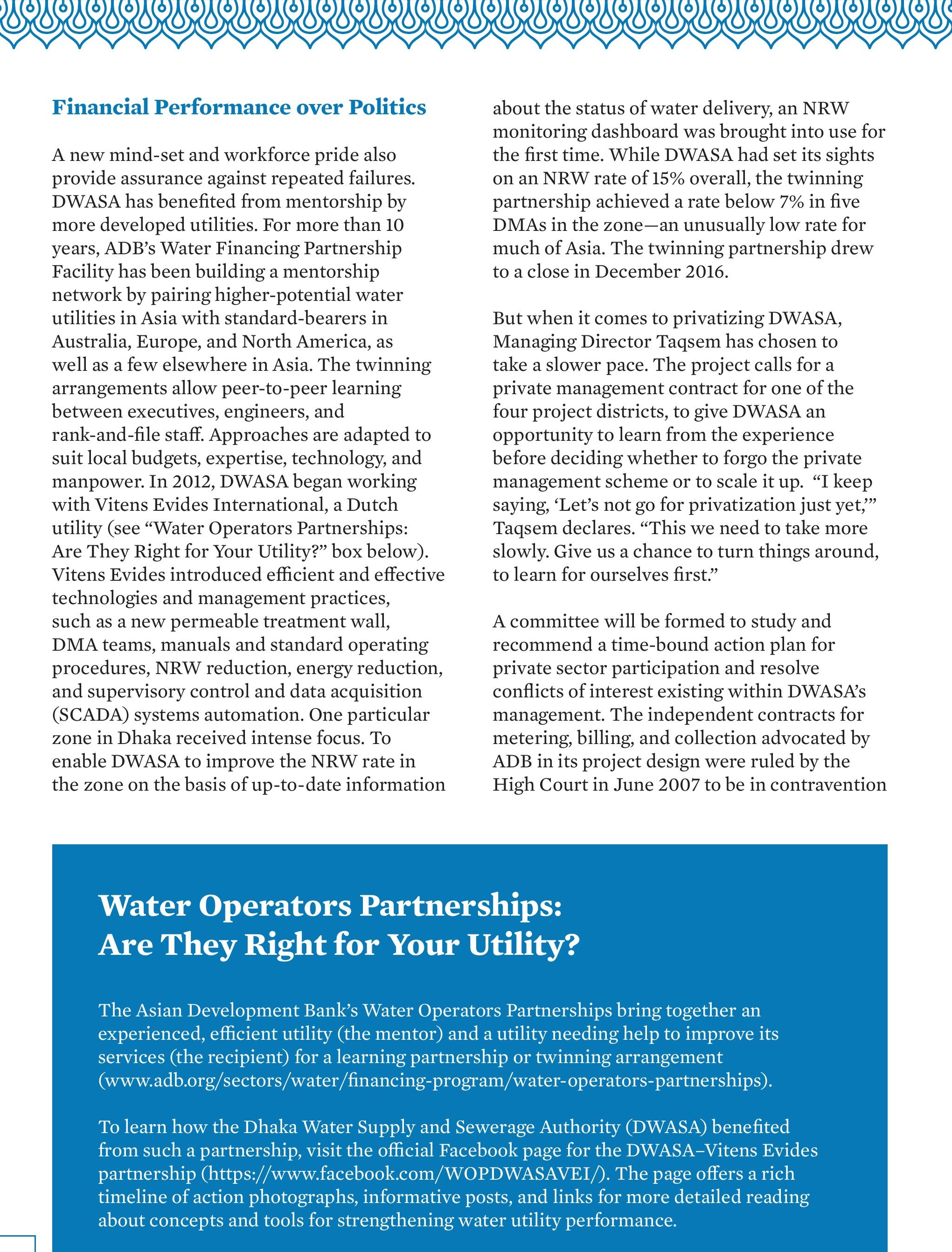

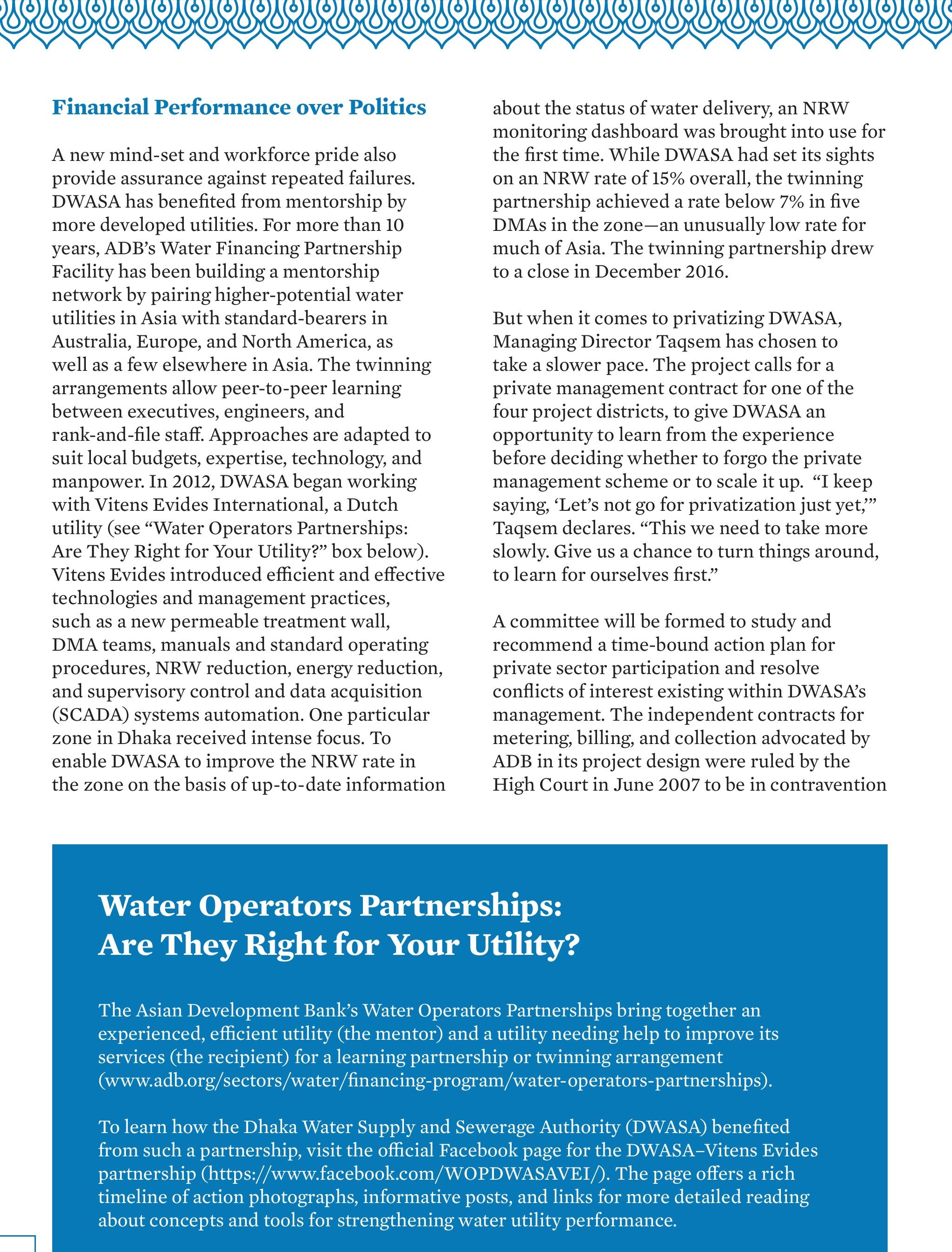

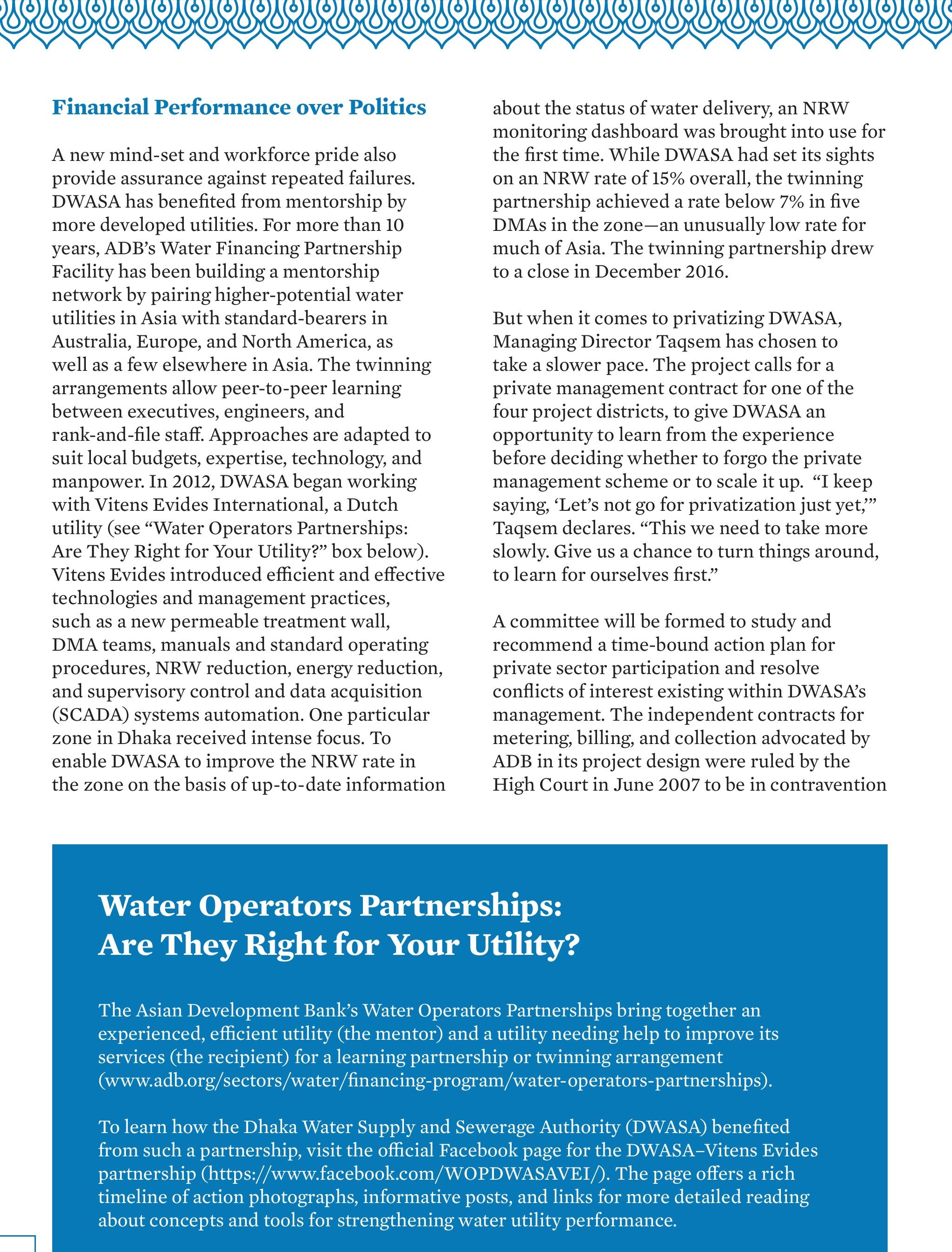

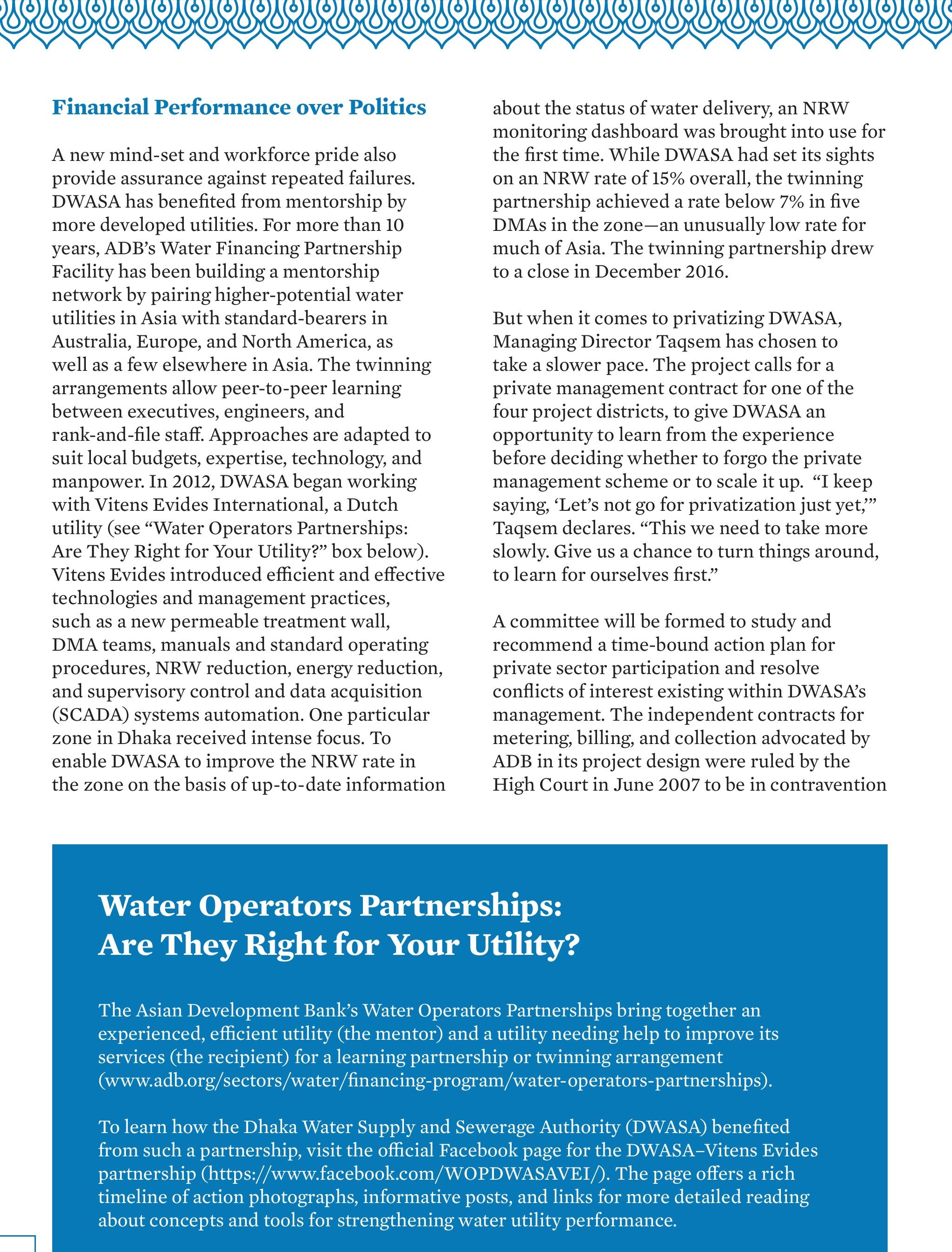

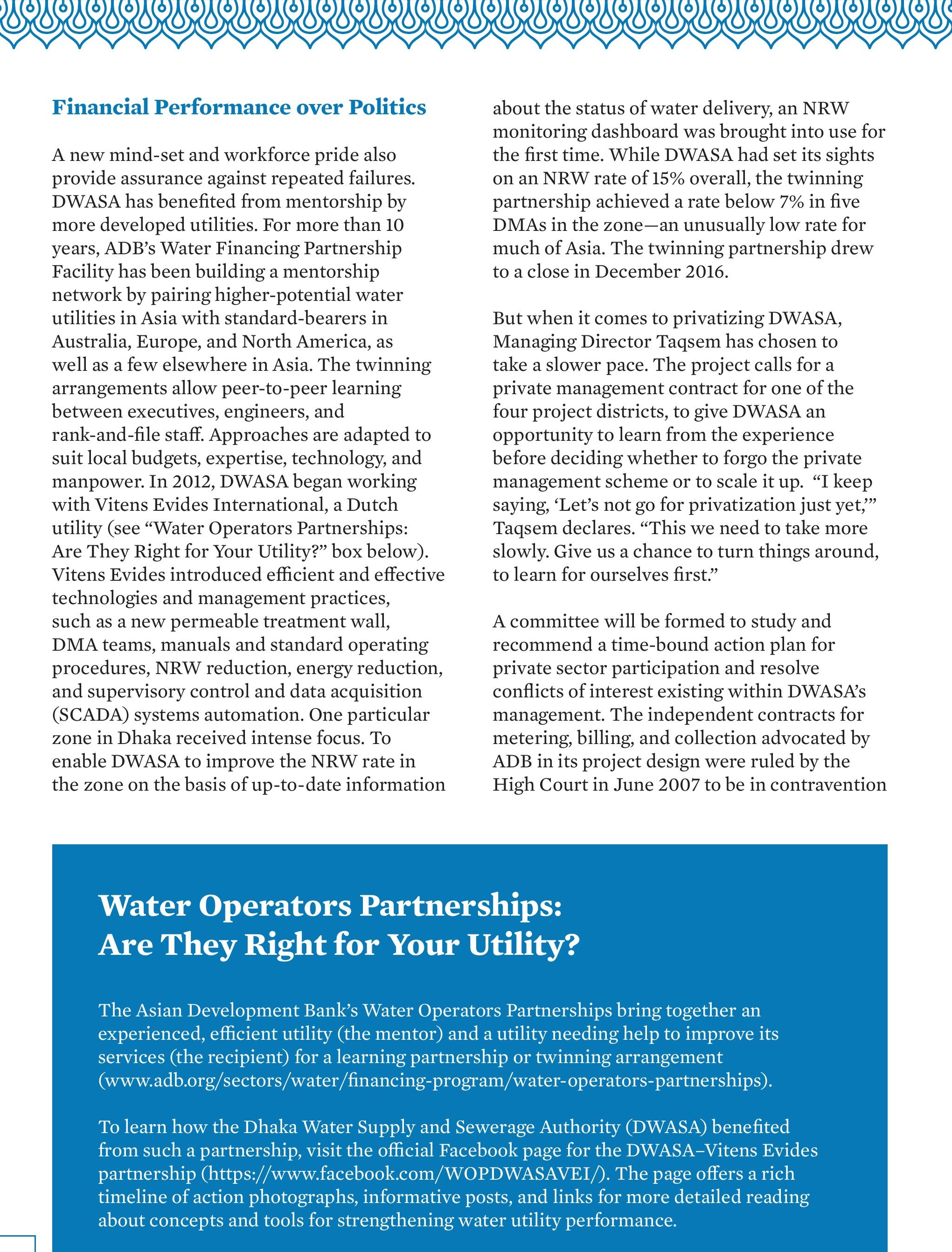

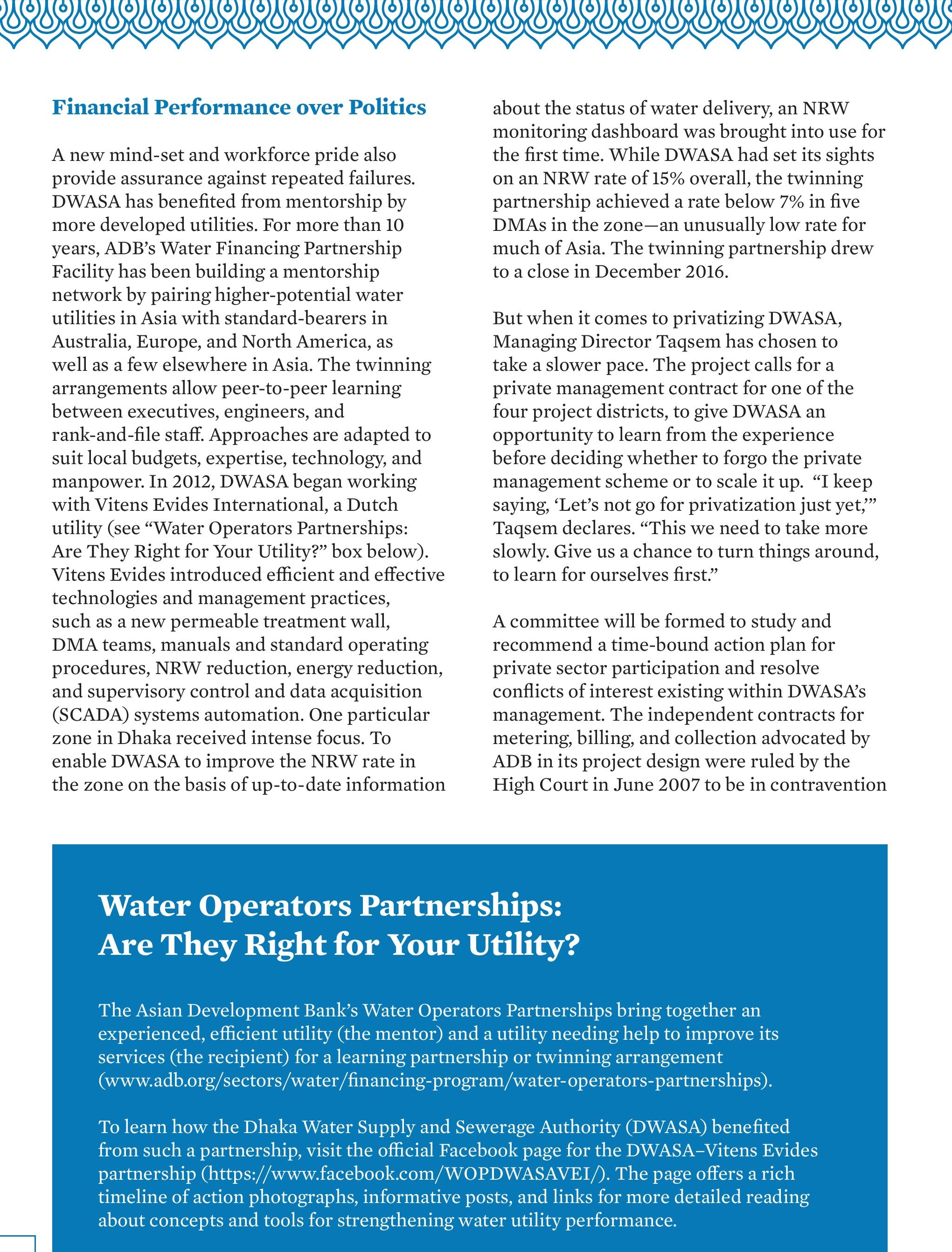

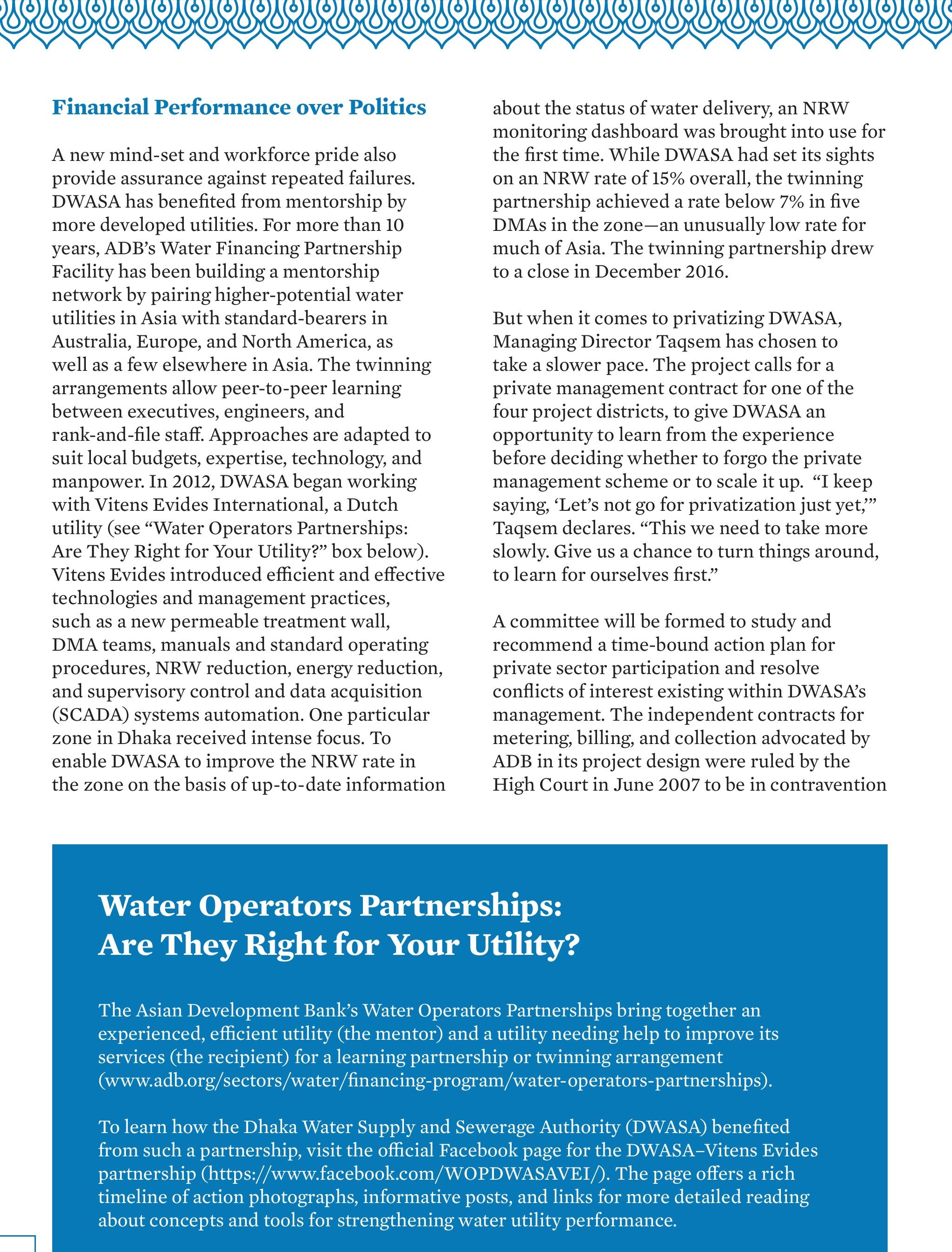

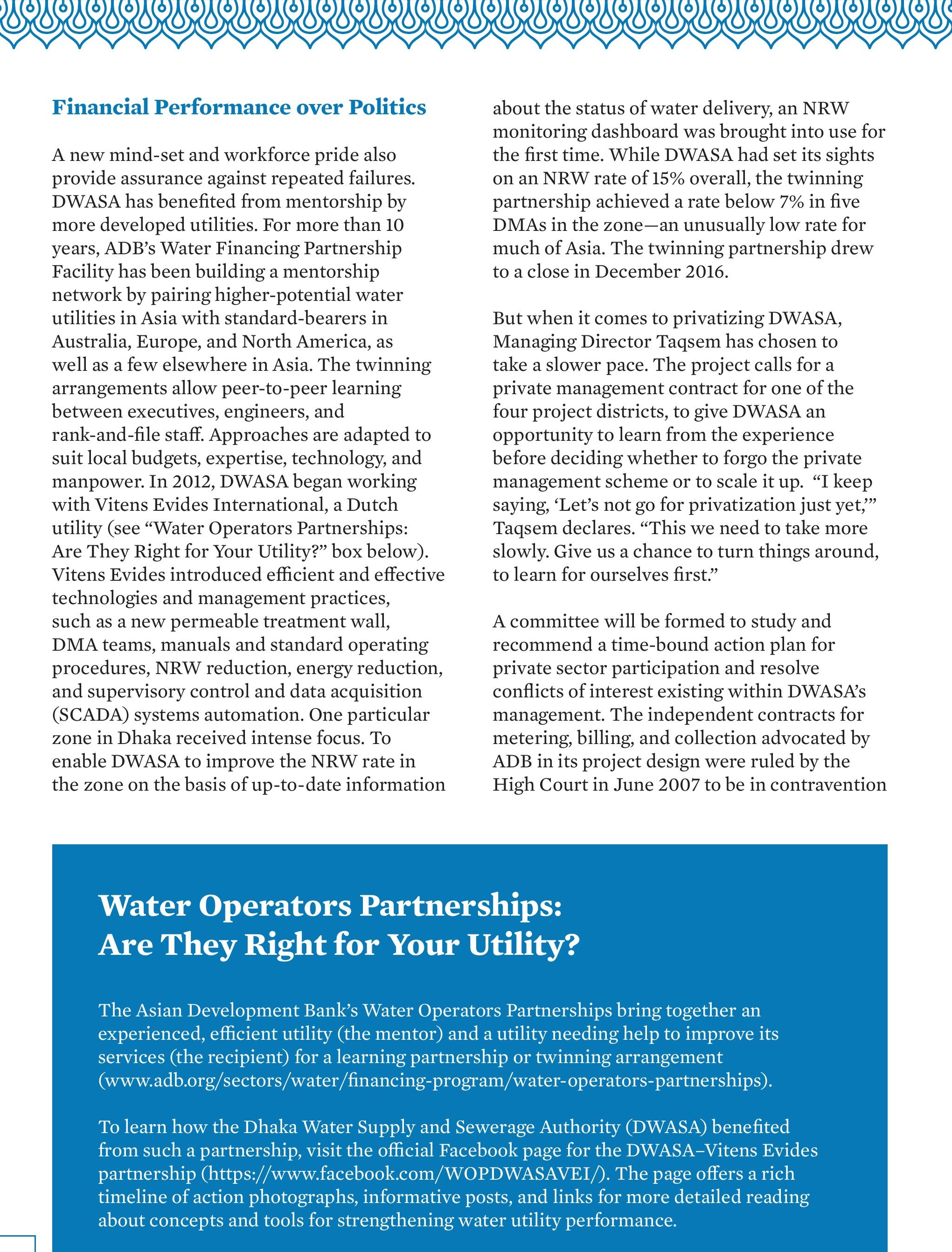

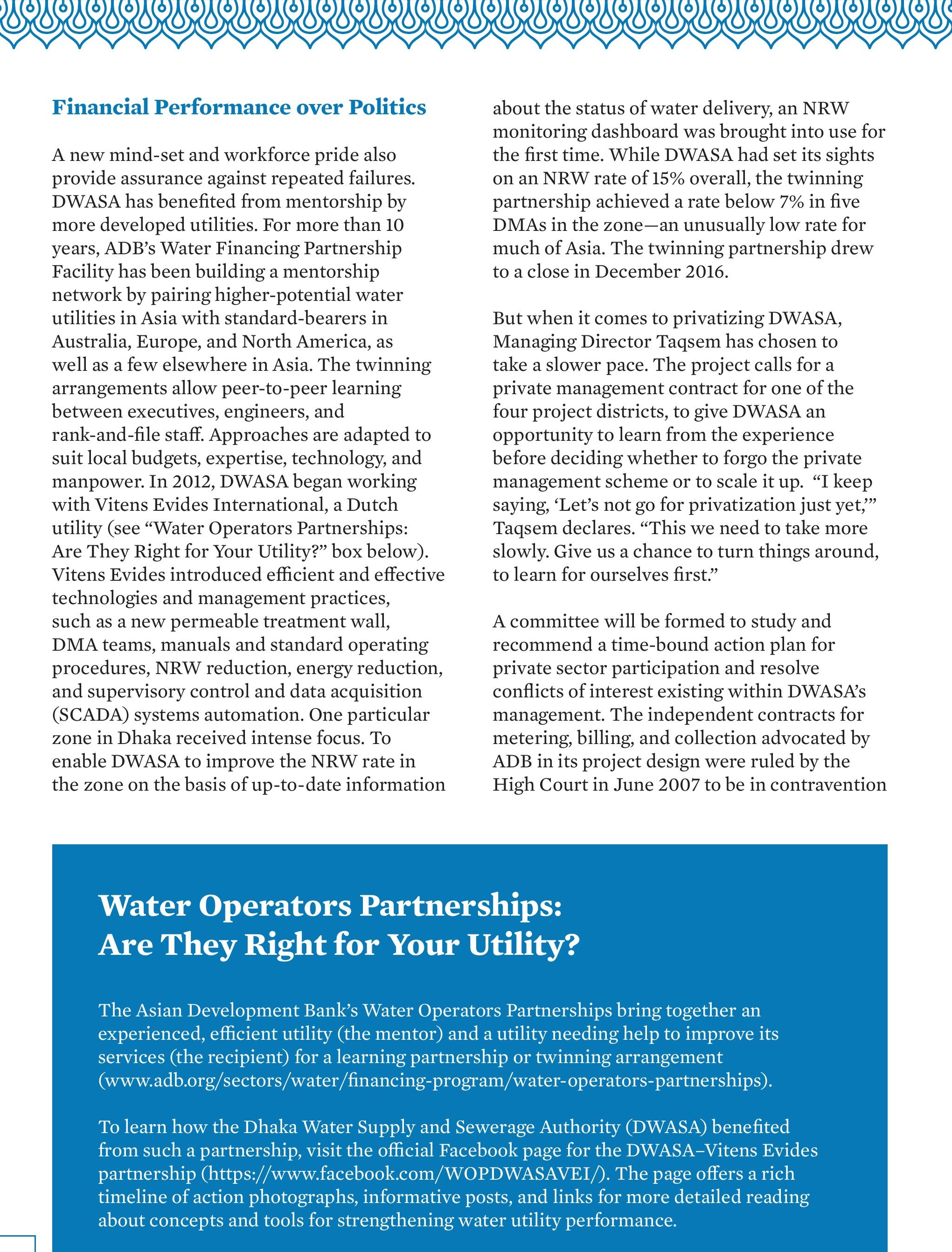

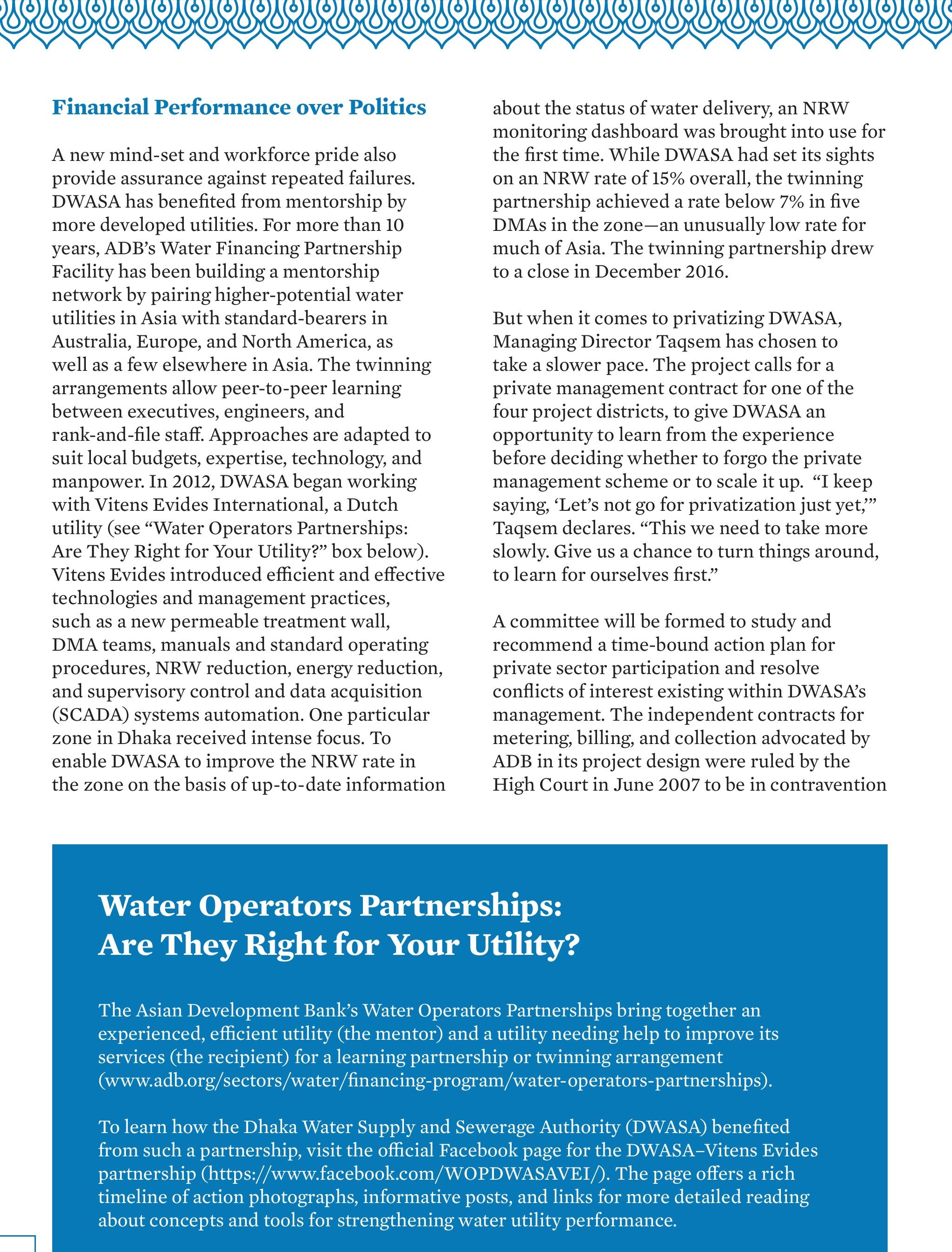

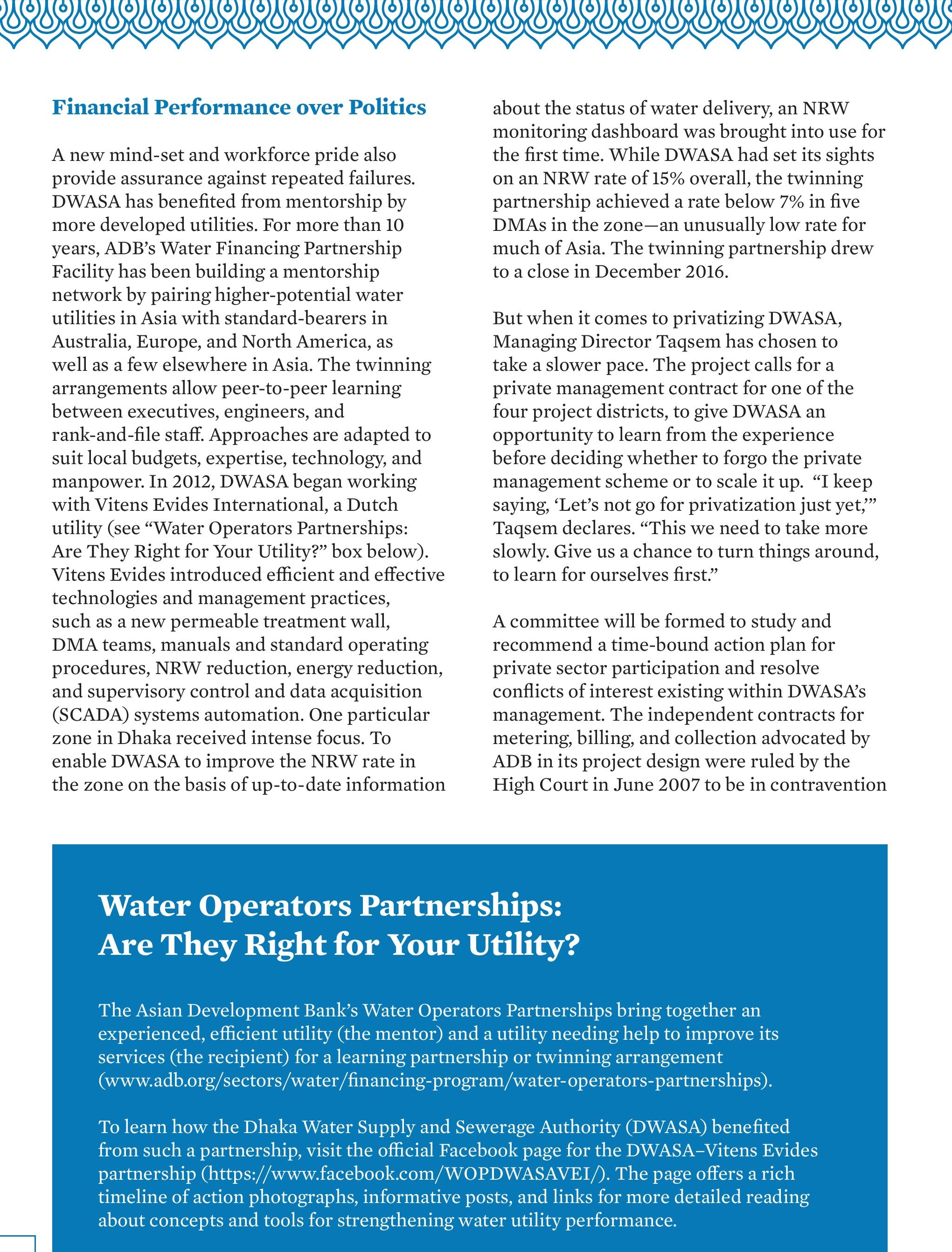

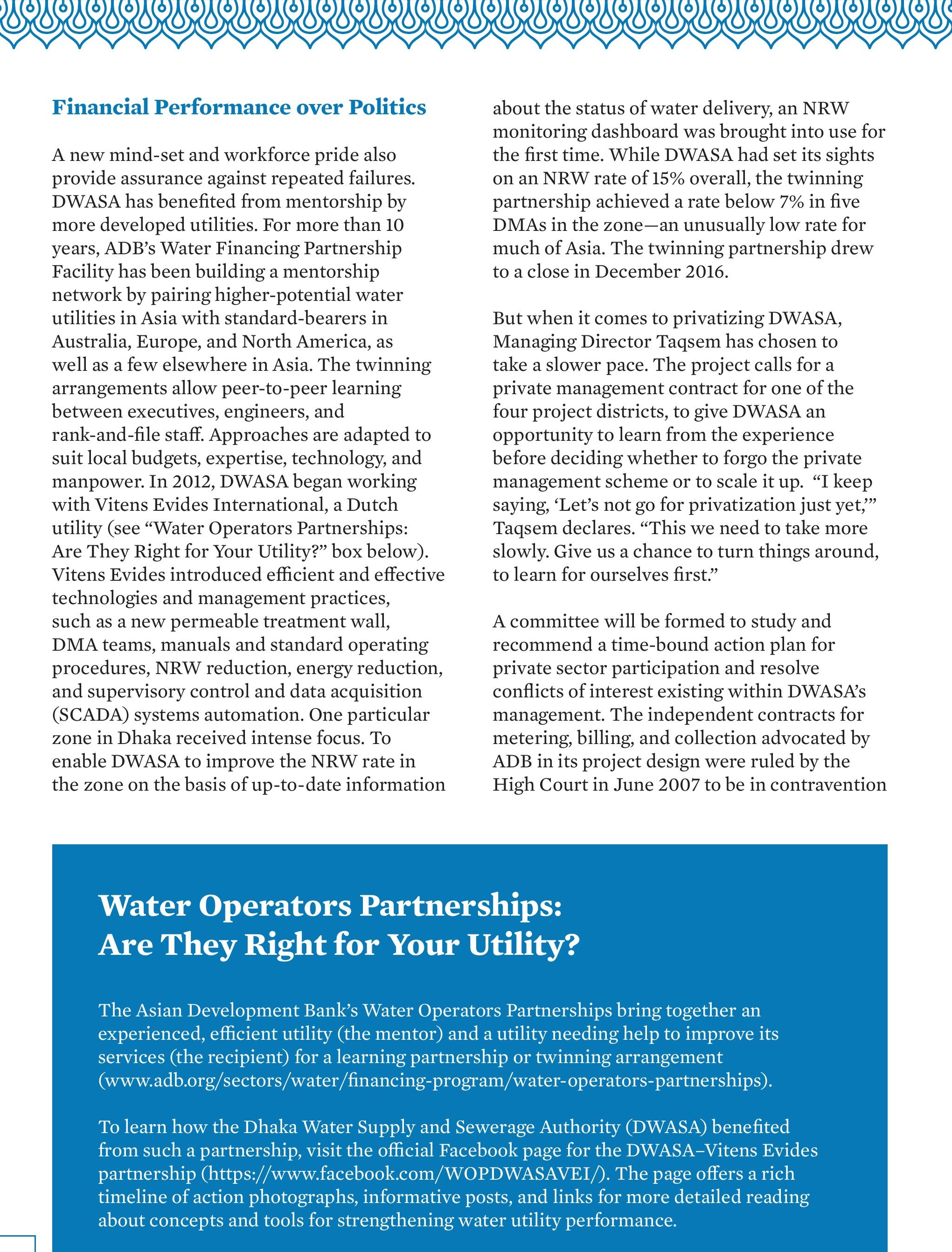

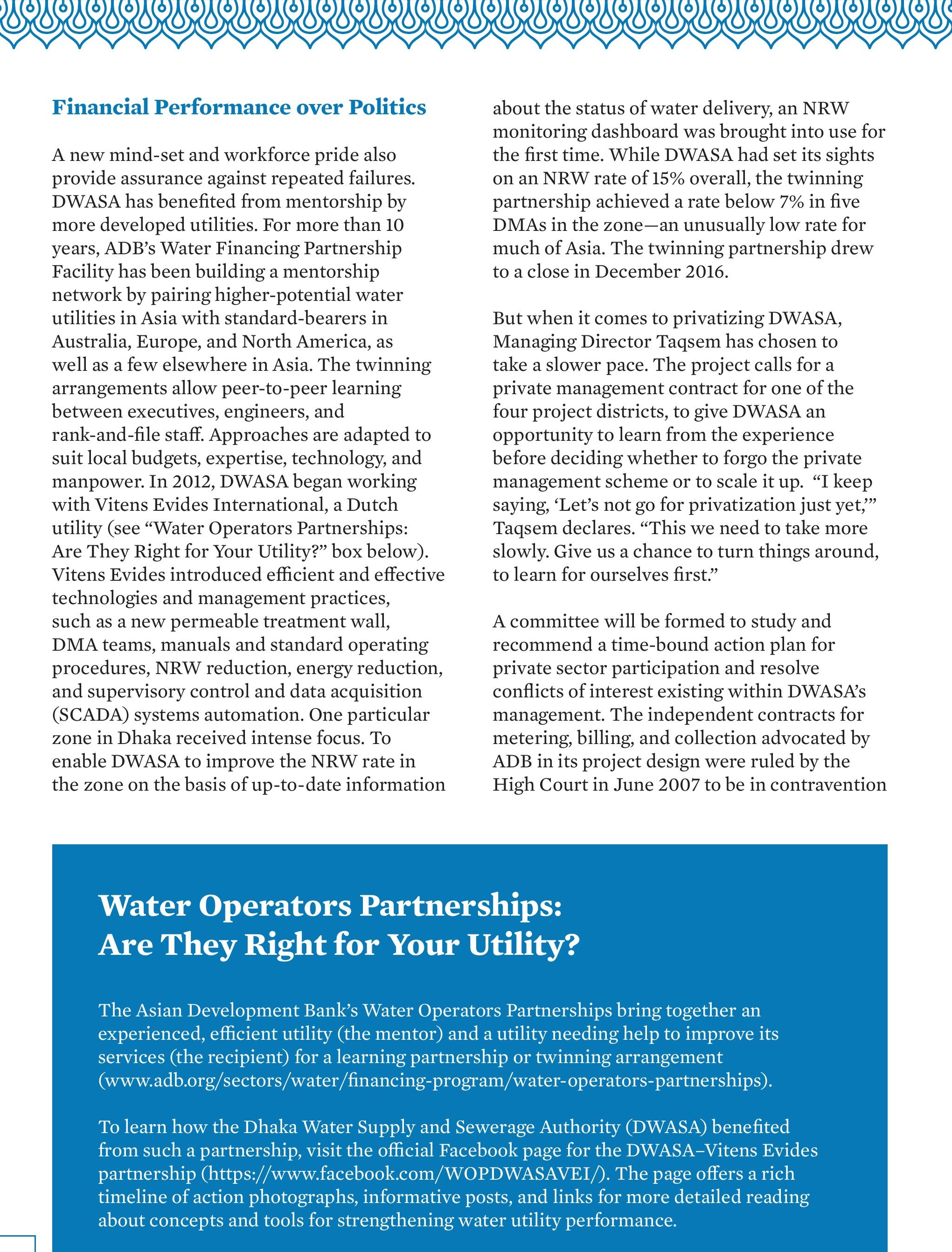

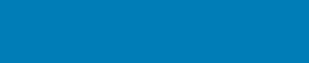





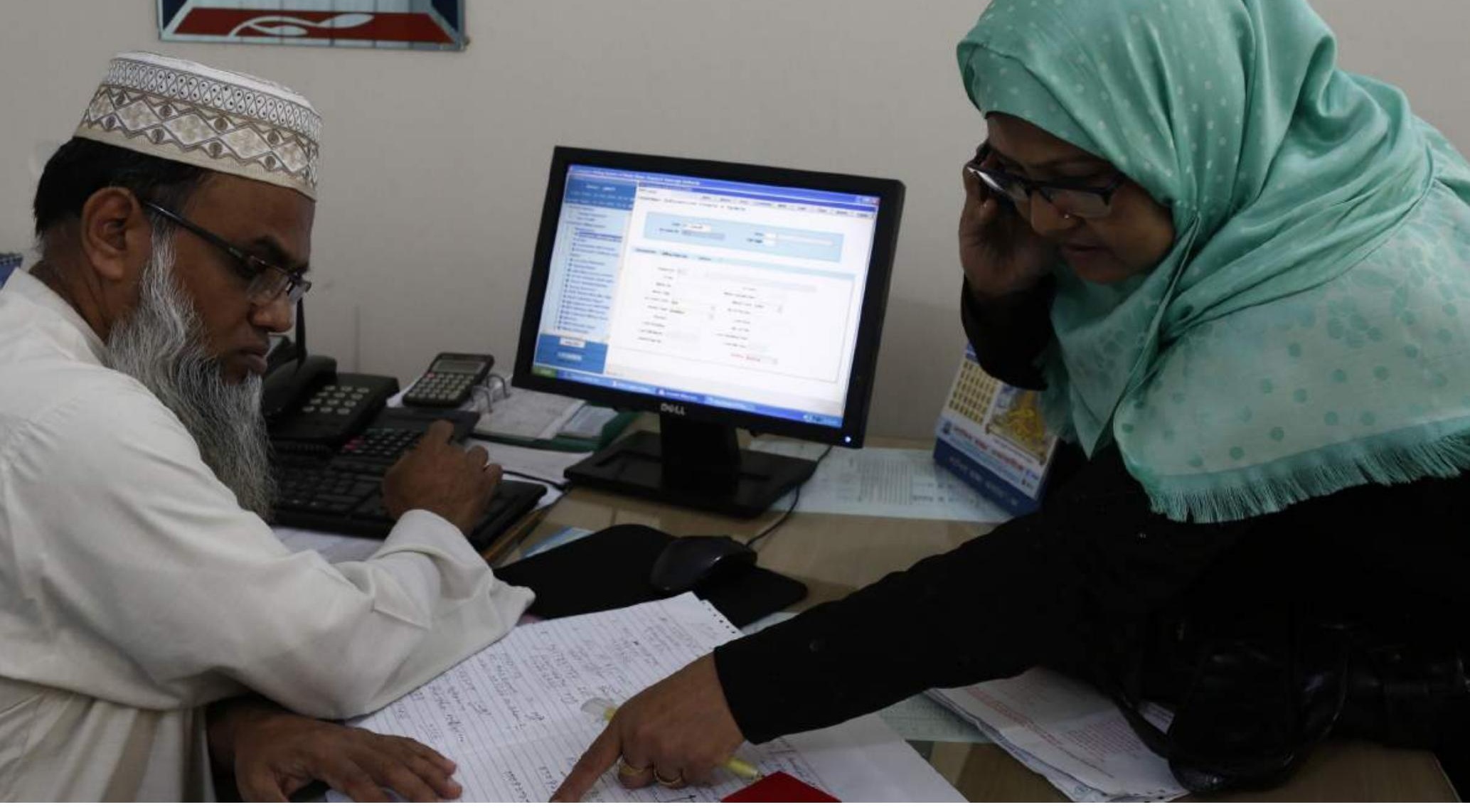

governance in the utility. The committee could prepare a study and make recommendations with a time-bound action plan. It could also review the existing PPI agreements and recommend ways to eliminate conflicts of interest.

For now, the unions are still part of DWASA's ecosystem, but their relationship with management is improving, Taqsem notes. "You have to build trust with your unions. Don't lie to them," he says. "At the start, we sat down with the unions and told them that we saw them as part of 'total management' but that they were not 'Management' with a capital 'M.' We talked with them-not negotiated, but talked-and I learned that no collective bargaining had occurred in 18 years. None at all." Previous management was unwilling, he says. Within 4 months of his arrival, he entered into collective bargaining agreements with the unions to prove the seriousness of his intent and his willingness to work with them. $\mathrm{He}$ believes the move, unpopular and risky though it may have been at the time, has paid off and has integrated the unions more effectively into DWASA operations.

\section{Transparency and Customer Relations}

The project called for an overhaul of DWASA's financial management. Best practices from the private sector and other model water utilities have introduced:

- strategic business planning using financial simulation models,

- results-oriented budgeting,

- sustainable debt management,

- tariff reforms,

- efficient and accurate double-entry accounting and auditing,

- accurate billing and payment collection through staff training and customer database maintenance, and

- transparency through the regular filing and publication of annual reports.

\section{(1)}


DWASA tariffs have risen and the rate of billing and collection has drastically improved. Before the project, only $64 \%$ of accounted for water, representing about Tk3 billion in annual revenues, was ever collected. By the end of 2016 , revenue collection was $98 \%$. With 24-hour supply, a larger customer base, higher tariffs, and better revenue collection, DWASA receives $\mathrm{Tk} 9$ billion annually-three times its preproject revenues.

Tariffs have not been fully restructured to cover the entire cost of the services, serving as a reminder of the political reluctance and social sensitivities associated with charging for a basic human right. Decision makers must remain sensitive to affordability to low-income users while raising awareness among other government agencies, political actors, and the public of the need to charge correctly to maintain the quality of service. But tariff reforms have made substantial progress. Under the ADB investment program, DWASA obtained the government's approval for a substantial increase in tariffs-more than
17\%. "This remarkable achievement improved financial viability, as the previous tariff level was quite low," observes Akira Matsunaga, an ADB project officer who designed a follow-up investment that benefited from the tariff adjustment.

\section{DWASA Breaks Ground with Self-Initiated Gender Strategy}

Rina Sen Gupta is a gender expert, one of the most sought after in Bangladesh. She is warm and, faced with the common insults and the disinterest and outright contempt shown to women, she smiles where others might wince. She is used to all of that. Implementing the Gender Action Plan with DWASA was no different from other projects.

"When I started working on this project, I would walk into DWASA wearing my ADB identification card and people would wonder what business I had being there," she recalls, adding with a laugh, "But now when I go there, they know exactly who I am and what I'm

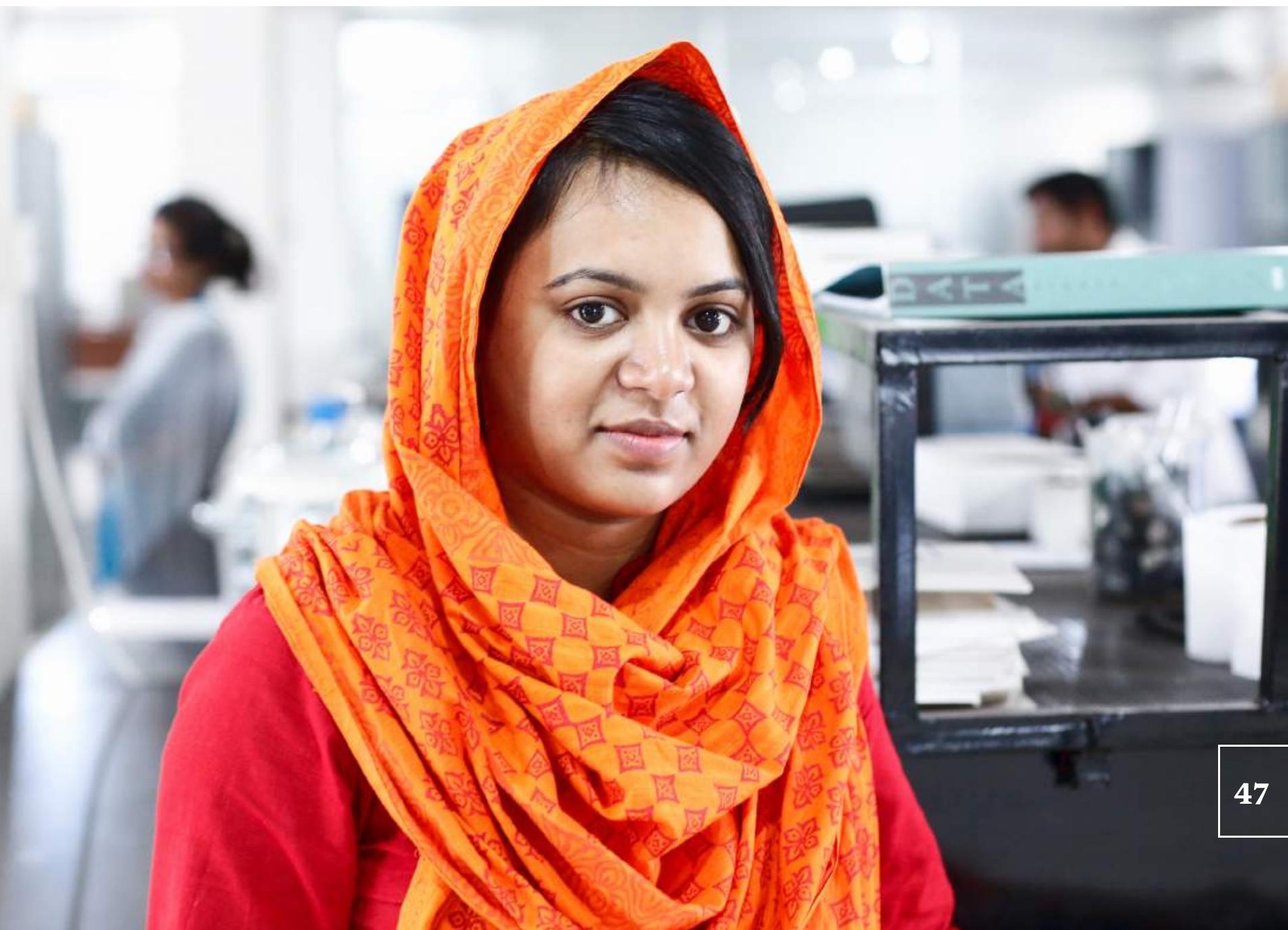




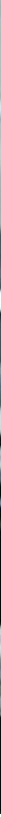

doing there, and don't think twice about it." Time and persistence do change things.

The Gender Action Plan was a key component of the ADB-financed program loan. ADB staff insisted on a plan that went beyond standard activities and indicators, to ensure genuine socio-organizational reform within DWASA. "Whenever you go for any gender intervention, you have to ask about the culture where this will take place-what the relationship between men and women is like, who will do the work, and who should be allowed to do the work," Gupta explains as she looks back on the early days of working on the ADB investment in DWASA, knowing how closely ADB staff would be monitoring progress on the gender components of the program. "This project has been groundbreaking for gender relations in Bangladesh," Gupta proclaims.

But breaking ground took time. At first, Gupta recalls, people were threatened by the mere mention of gender. Phone calls and messages went unanswered. Meetings were difficult to arrange. Then finally, at one meeting that did take place, a breakthrough was made. The project's gender experts were able to connect the men around the table with the mutual benefits of promoting gender equality and strategizing for it.

"We have international agreements and national policy-plenty of policy," Gupta remembers telling the group. "But government must turn that policy into action, and action needs strategy and plans. We must help the government understand that it is the implementer."

The project consultants worked with DWASA on a "gender strategy," a plan and a commitment to do more and do better for women in the workplace through equitable hiring practices and comprehensive training for both men and women. The drafting of the strategy did not start until after several rounds of training at all levels to sensitize staff to the issues of gender bias and discrimination.

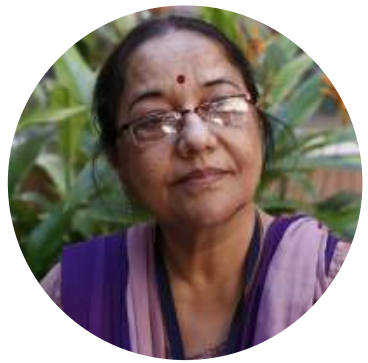

"This project has been groundbreaking for gender relations in Bangladesh.... I have been working for 33 years, and yet I was surprised at how frank the participants were. The training went very smoothly because of that." 
"You can't start developing a strategy right away," Gupta points out. "You have to start with the basics: What is gender? Why is it important to talk about gender? How can we use gender to improve our work? The answers to those questions don't come very easily. You must cultivate the land before you plant the first tree."

"The people you are working for have to be frank with consultants and trust them," she goes on to say. "They have to be honest about the culture within the organization or office. Honesty and trust require relationshipspersonal connections with people and different approaches."

Starting the training program at the lower levels of the organization gave the consultants considerable opportunity to gain insights into its culture and gender relations. "The staff were so very good at role playing," Gupta notes. "The men would even demonstrate how they would put down women at work and at home, the scolding they would give them. I have been working for 33 years, and yet I was surprised at how frank the participants were. The training went very smoothly because of that."
A dramatic change also occurred among women staff members, who started out not wanting to enter a room when certain men, generally those in positions of power, were around but eventually summoned up enough confidence to present plans and strategies before them.

Gupta explains, "With gender, you have to take your time. Gender is deep culture and you are dealing with people's beliefs. You have to take your time, because it's not just about getting the Gender Action Plan done. It's about changing a person's mind."

Gupta's approach to gender training in Bangladeshi and other traditional societies follows four gradual steps: listen, learn, believe, and then practice. "When some participants resist," she says, "I tell them 'You don't have to believe or practice what I am saying. Just listen and learn.”

The enabling environment is everything. "People leave a job or even a marriage because they can't do what they need to do, or be who they need to be. This is human nature."

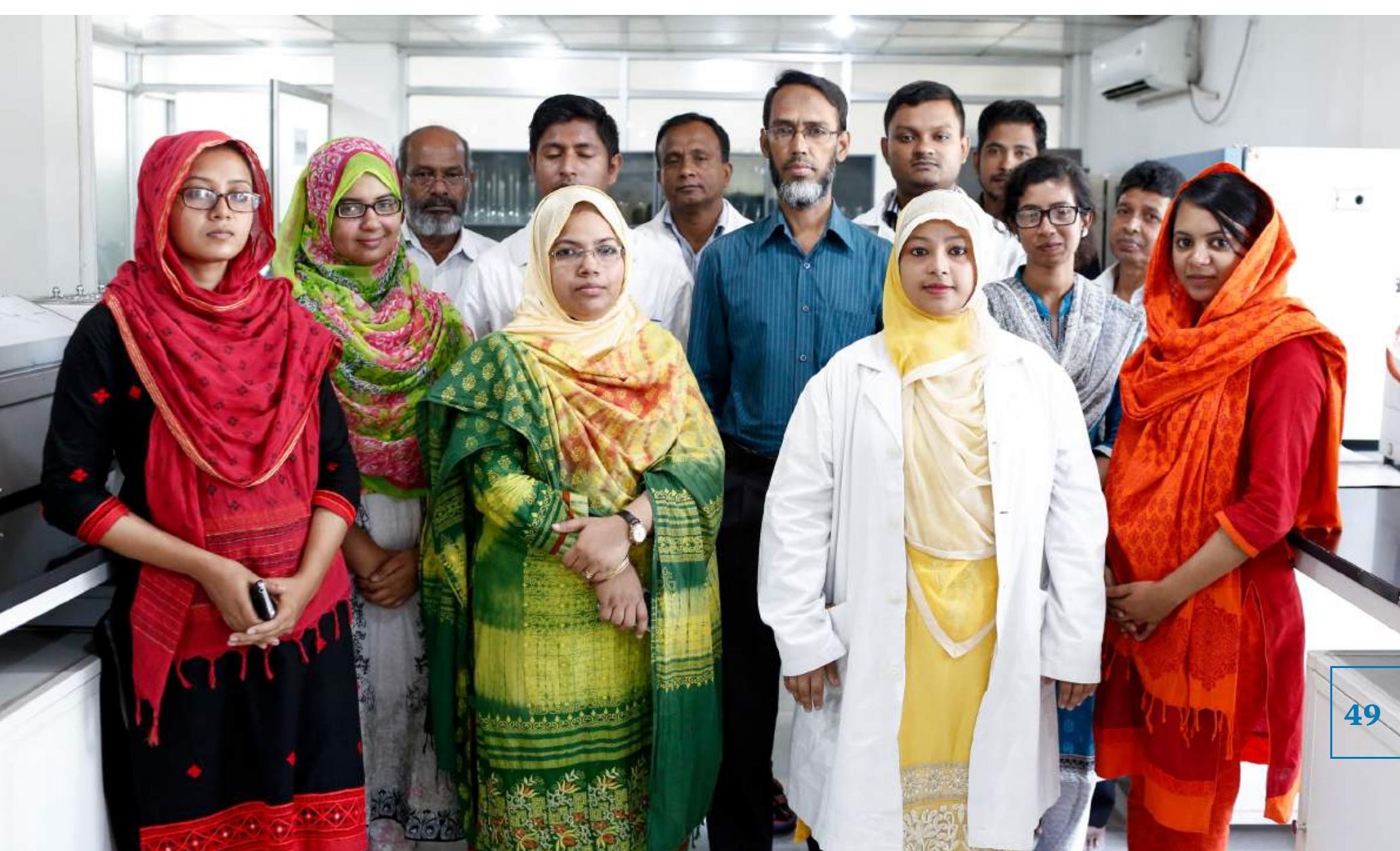




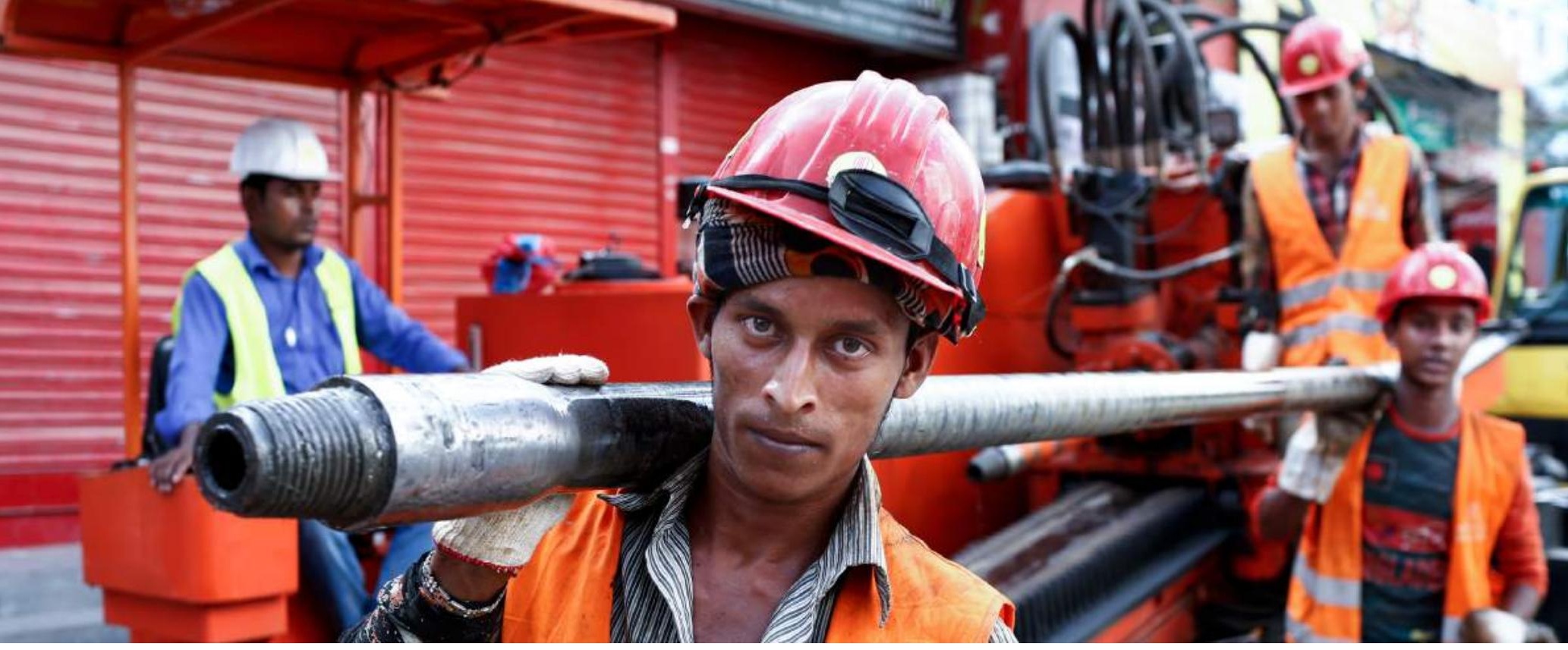

The Gender Action Plan, a constant feature of ADB investments, did not require DWASA to develop or approve an overall gender strategy for the organization, although ADB staff strongly pushed for such a strategy. However, DWASA pursued its adoption and approved the proposed strategy in the fourth quarter of 2015. By January 2016, new opportunities were opening up for women at DWASA.

When Tahmina Begum, a chemist, transferred to the DWASA Central Laboratory in 2011, she was the only woman working there. Now, six women work in the laboratory, in a professional capacity. All six were hired in 2016.

"The gender strategy for DWASA is working," declares Wahida Begum, an engineer and gender focal point at DWASA. "It promotes the rights of women, and even gives preference to them in the hiring process. Of course, women must be competitive, too." She adds that, as far as she can remember, gender issues were never discussed in DWASA or elsewhere before the project. Now it is a familiar topic.

"I feel very comfortable, very easy working in DWASA," Tahmina Begum declares. "For many women, government work may not be so gender friendly, but here it is-very much so."

\section{NGOs Fill Unique Role, Make Distinct Contribution as Communicators}

With support from the project, DWASA worked with NGOs and used mass media to keep the public informed about the project and the changes that would affect people, such as local construction schedules, changes in the water tariff, meter-reading and water- (and money-) saving tips, the negative impact of suction pumps, and the new billing system.

Support for proper and legal connections in the slum areas proved especially important and necessary.

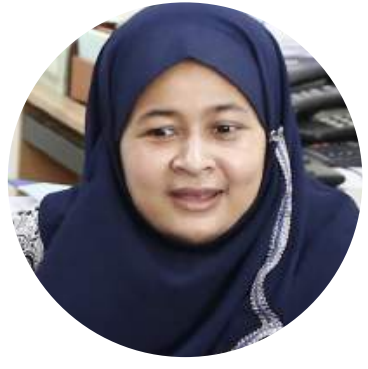

"The gender strategy for DWASA is working. It promotes the rights of women, and even gives preference to them in the hiring process. Of course, women must be competitive, too." 
Six NGOs were contracted to

- raise DWASA water users' awareness of changes resulting from the project and water conservation,

- assist DWASA in developing educational materials,

- coordinate community meetings and household visits by field workers, and

- mobilize urban communities and raise the quality of supportive services monitoring.

The NGOs were tasked with communication in two specific areas: project implementation, its impact on people, potential interruptions in daily life, and temporary economic losses resulting from restricted access to water supply during excavation, construction, and rehabilitation works in the proposed DMAs; and the value of water as a resource, its use, and the need for conservation.

\section{Awareness-Raising Topics}

DWASA contracted six NGOs to communicate with the public and raise awareness of issues and opportunities to safeguard infrastructure, conserve water, and avoid the consequences of illegal connections.

The NGOs gave DWASA water users

- fair warning about

- legal consequences of using suction pumps,

- illegal connections,

- financial and environmental consequences of wasting water; and

- information about how to

- conserve water,

- repair leaky faucets and valves,

- replace shower heads and faucets and install water-saving devices,

- read their water meters,

- understand billing statements,

- gain access to the new customer grievance procedure, and

- manage household solid waste (reduce, reuse, recycle).

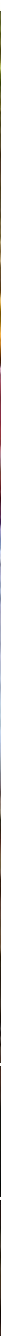




\section{Stakeholders}

Aside from using mass media approaches to communicate with the general public, NGOs reached out to specific groups of people whose roles in society have multiplier potential.

These groups included

- mothers;

- community leaders;

- CBO officers;

- religious leaders;

- domestic helpers, drivers, and gardeners;

- student leaders; and

- schoolteachers.

\section{Strategic Approaches}

The NGOs fielded eight-member teams to work with gender-balanced groups and subgroups in their assigned zones and communities. Together they found the following strategic approaches useful:

- Agreeing on an action plan before undertaking any activity.

- Organizing community meetings and household visits to raise awareness of the proper use of water, prevent water misuse, point out inaccuracies in meter reading, avoid pump cavitation, prevent overflow from overhead tanks, show how overhead and underground reservoirs are cleaned, and demonstrate proper solid waste removal to prevent contamination of water supplies and improve public health and hygiene. Waste reduction, reuse, and recycling was categorically emphasized.

- Reviewing action plans and progress in monthly coordination meetings; solving issues faced in the field and sharing information and lessons from the field.

- Implementing special activities to control water use and promote waste recycling in prayer houses (mosques, temples, and churches) and among religious leaders.

- Conducting thematic meetings with civil society in zones where Parliament members work and live.

- Sponsoring student forums with school management committees and teachers to develop student ambassadors for water conservation at home, in school, and in the community.

- Visiting households and motivating residents and specifically domestic helpers (maids, gardeners, drivers, caretakers) to

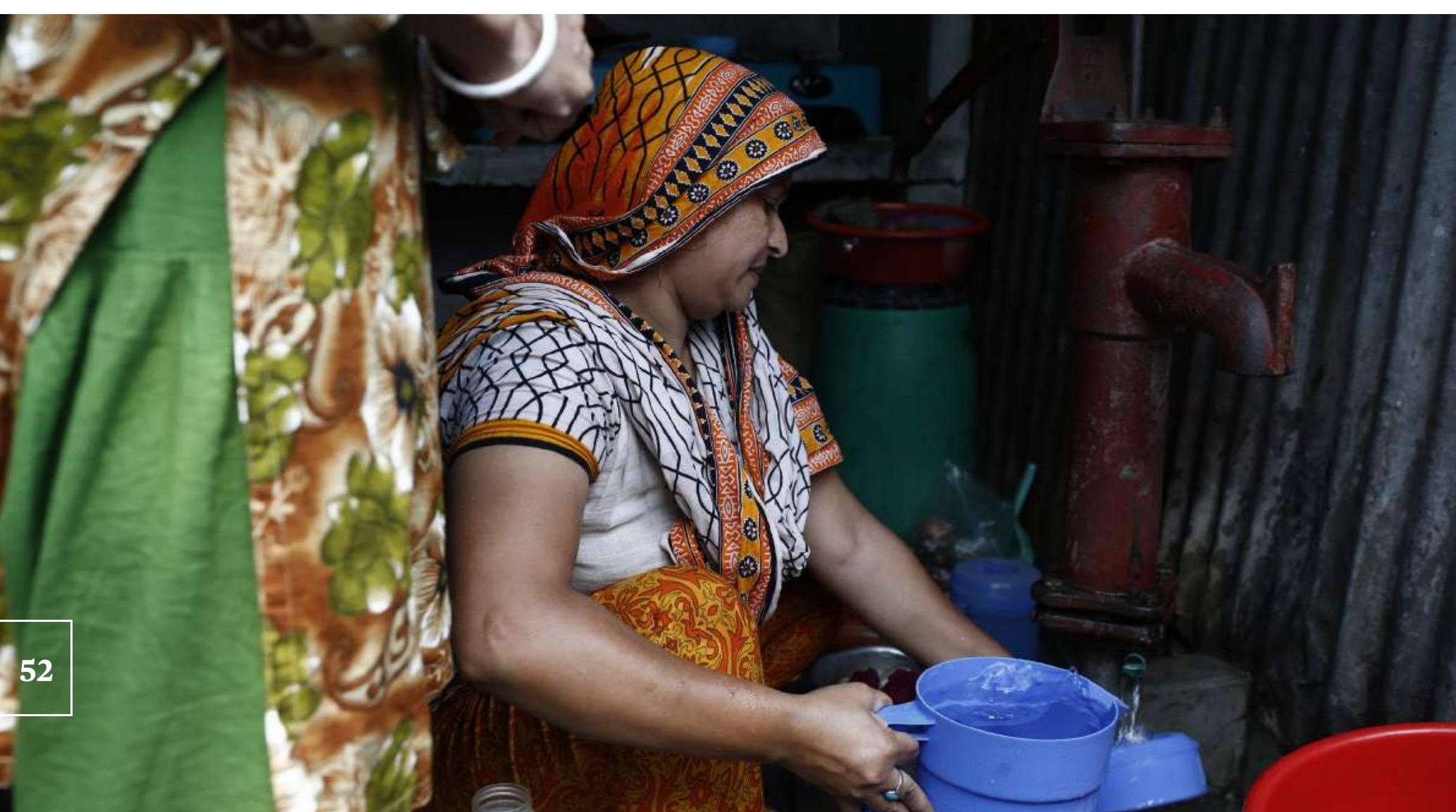





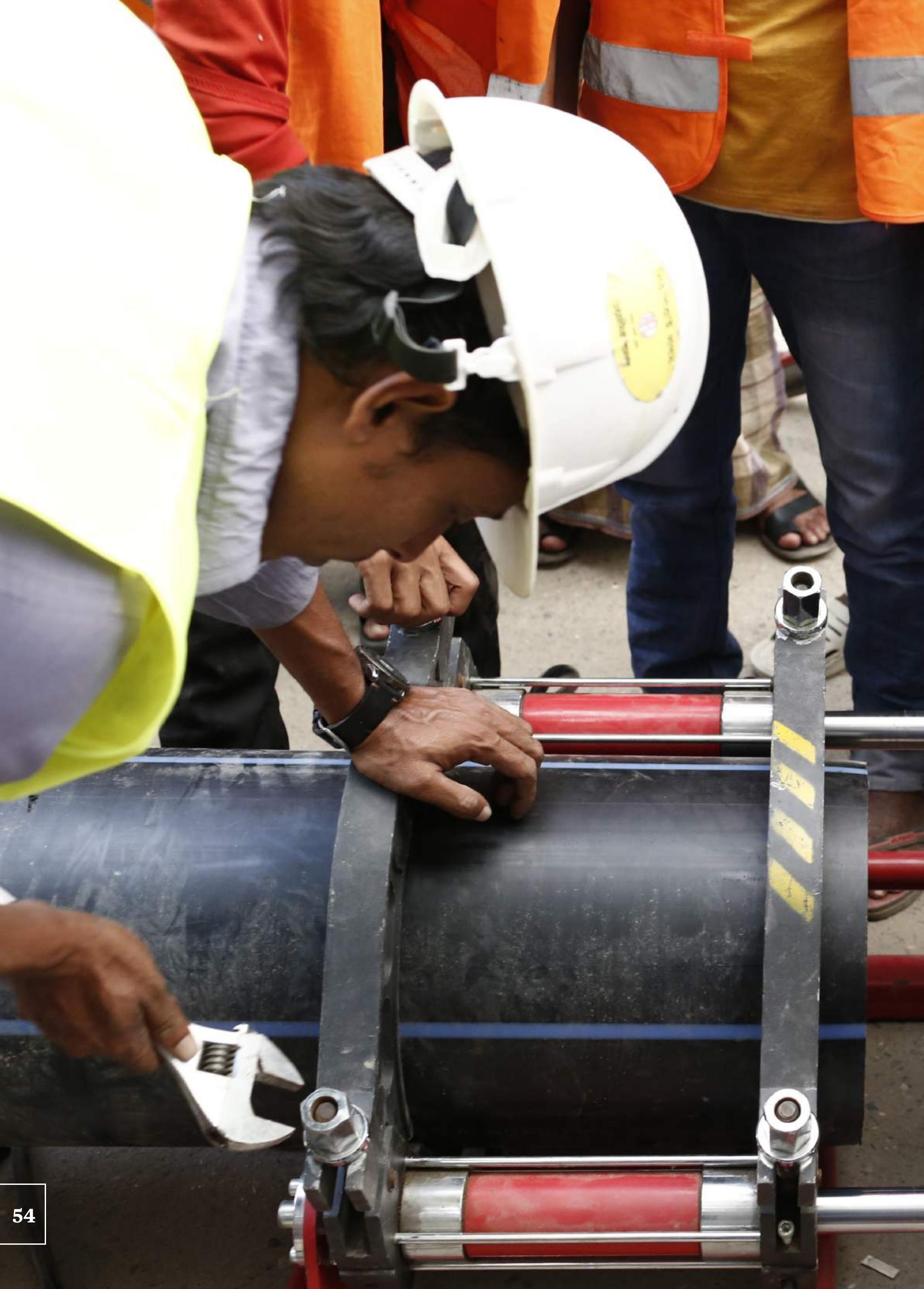




\section{FUTURE TURNAROUND Momentum, Fresh Investments Propel DWASA Forward}

DWASA's success was most unlikely. It sprang from determination, innovation, and the belief that people-financiers, engineers, managers, sales people, plumbers, or neighbors-want to do good work and make a difference with their work. Development should never be a modest success. The poor need overwhelming success, in their favor, to move up the ladder of development. DWASA's overwhelming success brought benefits to everyone. Sector reform meant that other water utilities in other cities in Bangladesh could operate in a more enabling environment. Dhaka's poor did not have to wait or accept less while the middle and upper classes benefited from large-scale infrastructure development. NGOs were reminded of their unique role and the singular impact that comes from walking with the poor and being that fair, helpful, trusted voice between government and the public.

"We were a water-crisis city, but we're coming out of that now," DWASA's Taqsem proclaims.

"We're productive. We actually have excess supply but this is not environmentally friendly, sustainable, or pro-people. It's nearly all still groundwater, not surface water. Twenty to thirty percent of Dhaka is slums and they do not all have legal connections to water. Until they do, we will not be environmentally friendly or sustainable or pro-people." According to public opinion, DWASA is doing a good job. In a 2016 Citizen Report Card Survey in all 11 DWASA zones, nearly $82 \%$ of the respondents reported no service failure in the previous 12 months and $12 \%$ noted only one service failure. Forty-four percent said that the compatibility between their bills and services received was "good"; $36 \%$ found the value for services "acceptable." As a service provider, DWASA was rated "good" by $47 \%$ of those who replied to the survey. Volume, pressure, continuity of supply, and quality of water, the majority said, was "excellent” (2\%), "very good" (18\%), or "good" (37\%). Disaggregating the results by zone reveals remarkably more positive responses from project zones.

The achievements of DWASA's turnaround became possible because of Taqsem Khan's highly professional approach, and meticulous leadership, and guidance. Taqsem steered critical operational constraints in implementing programs through his professional, contextual, and social intelligences. Taqsem exhibited his self-efficacy, conscientiousness, and rapport building skill at highest level, and was able to change DWASA from dysfunctional utility to one of South Asia's leading public utilities.

\section{"We were a water-crisis city, but we're coming out of that now."}

Taqsem Khan, managing director, DWASA 


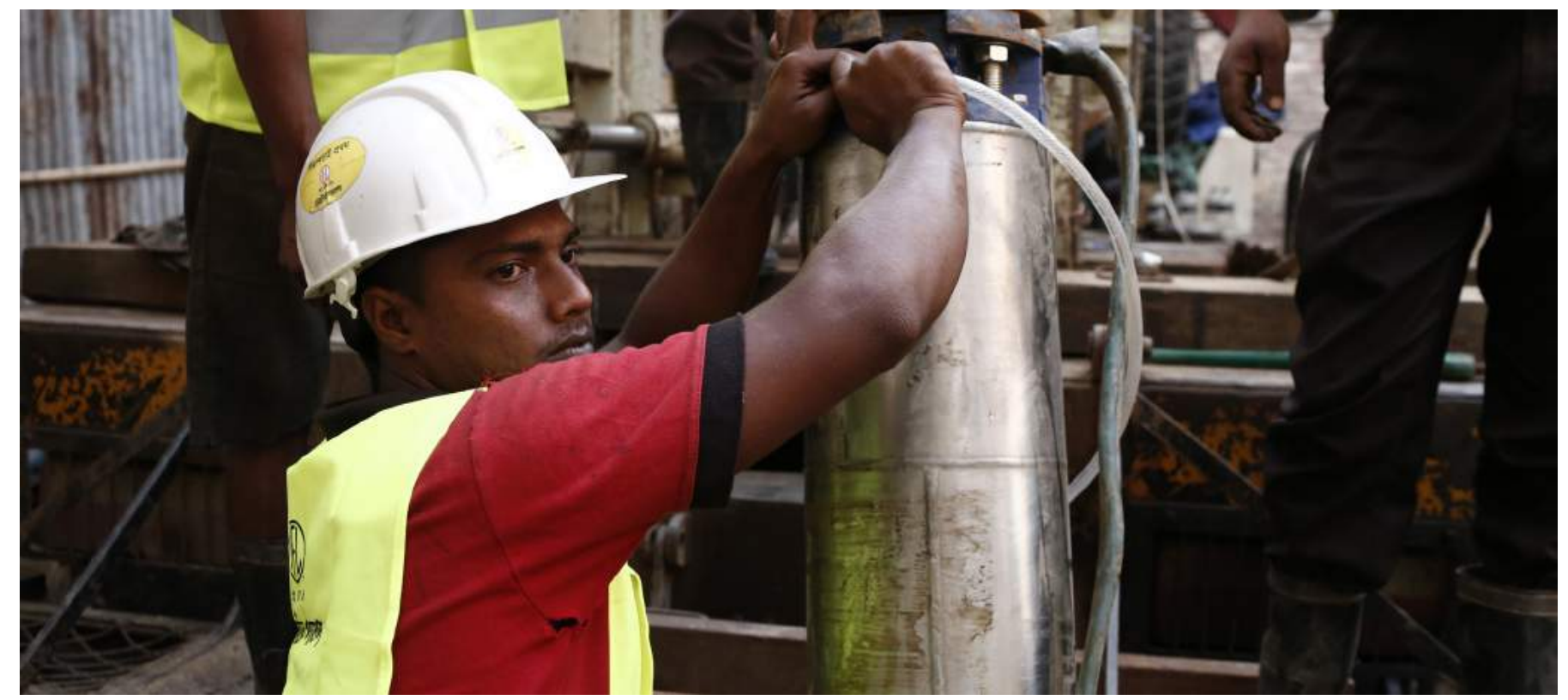

Seven years after Taqsem cast a vision for DWASA and declared it capable of becoming the best public water utility in South Asia, its employees have risen to the challenge and made it true. Their public water utility is South Asia's best, and they proudly welcome delegations from India, Nepal, and Sri Lanka eager to learn from their experience, while also continuing to learn as they did for nearly 5 years from the exceptional Dutch water utility Vitens Evides International.

But being the best in South Asia does not mean being as good as one can be. And successful does not mean satisfied.

"We haven't accomplished our mission, yet," Taqsem points out. "Our mission is to be environmentally friendly, financially sustainable, and pro-people. Until we have more surface water and until we have connected every slum, we have not accomplished our mission. We aren't environmentally friendly or pro-people until we've done that."

Quality will also continue to matter.

"People shouldn't have to drink bottled water," Taqsem says. By 2021, we want to be able to give you a glass of tap water and say, 'Drink this.' Now, we can't. The water is drinkable at the treatment source, but there are still issues in the network."
Taqsem's wish for his utility and the city may very likely come true. The DWSSDP set the stage for follow-on projects to provide the intensive capital investments required for a further shift away from groundwater sources and for the replication and scale-up of the DMA approach. DWASA has secured two additional project loans, which will cover the entire city and provide it with sustainable supply sources (see "Dhaka Environmentally Sustainable Water Supply Project" and "Dhaka Water Supply Network Improvement Project" boxes on the next two pages).

\section{“People shouldn't have to} drink bottled water. By 2021, we want to be able to give you a glass of tap water and say, 'Drink this.' Now, we can't. The water is drinkable at the treatment source, but there are still issues in the network." 


\section{Water Supply Project}

Status. Approved in Oct. 2013; and estimated completion in 2020.

Summary. The project will provide a new surface water supply scheme, including a new surface water intake, transmission mains, a water treatment plant, networks, and household connections. The project will also improve utility services, especially for low-income communities. The project will reduce groundwater abstraction by 150 million liters per day (MLD). The Dhaka Water Supply and Sewerage Authority (DWASA) looks forward to increasing the overall surface water supply to 1,900 MLD (including 500 MLD from this project), nearly $60 \%$ of the total water supply, by 2021 . To address wastewater management, DWASA approved a sewerage master plan in 2012 for the treatment of the incremental amount of wastewater generated by the project.

The project is organized into three main deliverable packages, or output categories.

Output Category 1: New surface water supply system developed. A raw water intake will be developed at Meghna River, about 30 kilometers $(\mathrm{km})$ east of Dhaka. Associated structures and a pumping station will provide a total of 1,000 MLD of raw water, though the new water treatment plant (WTP) at Gandharbpur will require only 525 MLD of raw water in the first phase. The WTP will serve the population of about 3 million. A design-build contract is aimed at incentivizing design innovation and ensuring integrated design and operation from the intake to the WTP. The same contractor will be engaged in the first 3 years of operation to prove the WTP's functionality and build the capacity of DWASA personnel to manage and operate the facilities.

\section{Output Category 2: Distribution network} strengthened. Continuing ongoing efforts to reduce nonrevenue water, distribution network improvements will be implemented in zone 6 of DWASA's service area. New or regularized connections at community or household levels will be provided in low-income communities in this zone under DWASA's existing pro-poor community support scheme. Public awareness-raising programs are aimed at improving understanding of water use and conservation, customer services, metered connections, and billing systems. The capacity of DWASA to engage with and support low-income communities will be strengthened. At the same time, feasibility studies and bid documents will be prepared for distribution network improvements in two densely populated zones in the DWASA service area to complete the distribution network improvement works.

\section{Output Category 3: Project management and administration adequately supported. Support will be provided for smooth and effective project implementation and operation by the project management unit of DWASA. As the nature and project areas of output categories 1 and 2 are distinct, two teams of management and supervision consultants will be hired. Three teams of nongovernment organizations will be engaged to facilitate the implementation of resettlement plans and assist in awareness-raising and community-related tasks.}

"The project basically scaled up the investment in nonrevenue water reduction, though it covered only one zone because of budget constraints," says Norio Saito, an Asian Development Bank (ADB) project staff who helped develop this project and is now deputy country director for ADB's Viet Nam Resident Mission. "But the project included support for the feasibility study and bid document preparation for network improvement in two more zones to enhance future project readiness. Slowstartup issues were addressed. So this was a very good sequence of activities."

Impact. Improved access to and quality of sustainable water supply services in Dhaka city.

Outcome. More reliable and more secure water supply for Dhaka city.

Financing. The project is supported with

- $\$ 250$ million from ADB,

- \$64 million from Agence Française de Développement, and

- \$136 million from the European Investment Bank.

\section{"The project included support for the feasibility study and bid document preparation for network improvement in two more zones to enhance future project readiness. Slow-startup issues were addressed. So this was a very good sequence of activities."}

Norio Saito, $A D B$ project staff, now deputy country director for ADB's Viet Nam Resident Mission 


\section{Dhaka Water Supply Network Improvement Project}

Status. Approved in June 2016; estimated completion in 2021.

Summary. In many ways, the Dhaka Water Supply Network Improvement Project picks up where the other projects left off. About 6.5 million people live in areas of the city not yet covered by the two other investment projects, which cover seven of the 10 zones in the city. This assures residents improved access to continuous, sustainable supply of water and a stronger utility.

Water losses are still the main reason for poor service delivery. Reducing these losses from $26 \%$ to less than $15 \%$ will increase the amount of water available to residents, eliminating the need for underground reservoirs and the use of illegal suction pumps to withdraw water from distribution lines, and underground storage reservoirs.

This, in turn, will improve the quality and reliability of the water consumed in the city, ease water-related public health risks, cut down the consumption of energy used to pump water, and help make clean water more accessible generally and in low-income communities.

If accompanied by appropriate water tariffs, the reduction in nonrevenue water (NRW) will also ensure the financial sustainability of the Dhaka Water Supply and Sewerage Authority (DWASA). Managing district metered areas (DMAs) professionally and keeping NRW ratios low are both critical to keeping DWASA's operations sustainable.

The project is organized into three components, or output categories.

\section{Output Category 1: Distribution network} strengthened. Building on the ongoing work of two other projects financed by the Asian Development Bank (ADB), the project will help improve the distribution network in new
DMAs not financed by the ongoing loans. The project will extend new or regularized water connections to low-income communities, where people rely on illegal water lines or private water vendors and pay higher charges than they would once the expanded systems are ready for use.

Output Category 2: Sustainable managerial capacity of district metered areas enhanced. DWASA's managerial and technical capacity will be strengthened to keep NRW low. The project will assist DWASA in preparing and implementing a sustainable NRW reduction plan; strengthening monitoring capacity at the zone level with renewed standard operating procedures, upgraded training modules, and the supervisory control and data acquisition (SCADA) monitoring and control system, and the pilot-testing of automated meter reading; and enhancing in-house capacity for sustainable DMA management.

Sustainable DMA management is aimed at addressing sustainability issues. Successful does not mean sustainable. "The next challenge is to sustain such a successful outcome," says Akira Matsunaga, ADB project staff who developed the project. "This is not an easy task. It requires institutional transformation."

\section{Output Category 3: Capacity for quality service delivery enhanced. The project will help DWASA prepare and implement an operational and financial improvement plan by enhancing the existing 5-year corporate business plan; build capacity for planning, design, construction supervision, and project management; prepare and implement a plan to make the public more aware of the need for demand control, water conservation, and better health and hygiene; render improved service to low-income communities; prepare and implement a water quality monitoring system; implement a gender action plan; and enhance project readiness for future investment.}

To sustain its efficiency gains, investment in DWASA's capacity to carry out operation and maintenance in the DMAs must be sustained, since a growing number of DMAs will be commissioned and handed over by contractors to DWASA operational staff under the ongoing projects. DWASA needs to institutionalize the DMA-based approach by updating operating procedures, training and orienting operating staff in DMA management, and developing a comprehensive DMA management plan. 
The project will help transform DWASA into a highly efficient and financially sound water utility.

Impact. Safe drinking water made available for all of Bangladesh's urban populations, aligned with the government's five-year plan for FY2016FY2020; and adaptive capacity of water sector enhanced to reduce climate change vulnerability, consistent with the national strategy for water supply and sanitation.

Outcomes. Sustainable provision of a more reliable, improved, and climate-resilient water supply in Dhaka.

Financing. The project is supported with

- $\$ 275$ million from ADB,

- \$200 million from ATF - Danida Loan,

- \$128 million from Agence Française de Développement, and

- \$44 million from the European Investment Bank.

\section{"This is not}

\section{an easy task.}

\section{It requires}

\section{institutional}

transformation." 


\section{Key}

\section{Statistics}

\section{5 million \\ Dhaka population}

\section{$-3.6 \%$}

Dhaka population growth rate

\section{$1.1 \%$}

National population growth rate

\section{-8 million people}

Project coverage

- From 1 system to 10 zones to 88 district metered areas

- ADB project covers 7 out of 10 zones

$-70 \%$ of Dhaka megacity DWASA coverage area

\section{$\$ 1.5$ billion}


DHAKA

WATER SOURCES

\begin{tabular}{l|r} 
Water Source & $\begin{array}{l}\text { Proportion } \\
\text { of National } \\
\text { Population } \\
\text { Served (\%) }\end{array}$ \\
\hline Stand posts & 5 \\
\hline $\begin{array}{l}\text { Public tube } \\
\text { wells }\end{array}$ & 15 \\
\hline $\begin{array}{l}\text { Shallow tube } \\
\text { wells }\end{array}$ & 60 \\
\hline $\begin{array}{l}\text { Household } \\
\text { connections }\end{array}$ & $<20$ \\
\hline
\end{tabular}

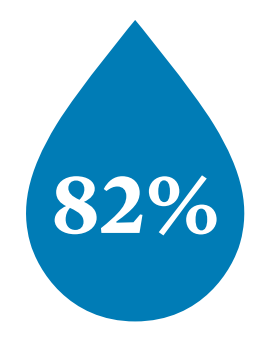

groundwater

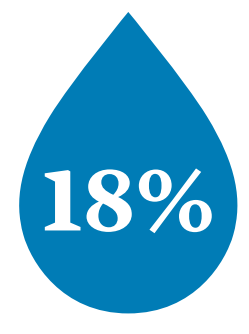

surface water

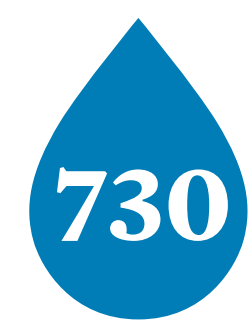

Number of tube wells ( $<200$ m below ground)

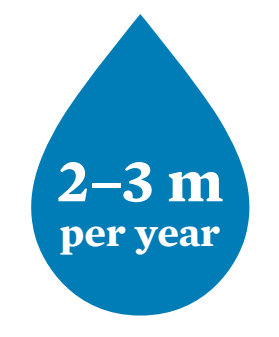

Groundwater loss

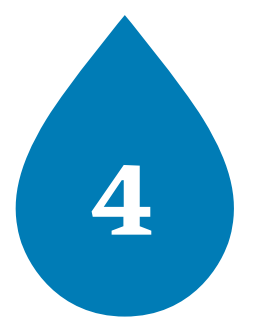

Surface water treatment plants

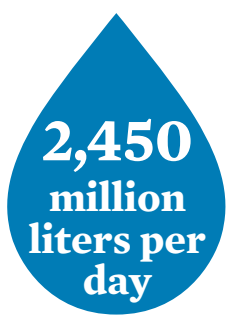

Production capacity

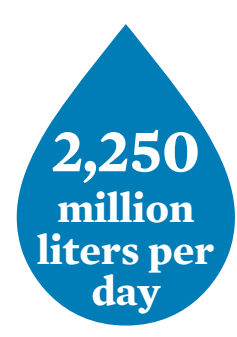

Demand

\section{Sanitation}

\section{$26 \%$}

of urban households nationwide with access to hygienic latrines

\section{$20 \%$}

of Dhaka households with access to water sewer

network

$2 \%$

of all urban households nationwide with access to solid waste collection

\section{$20 \%$}

Total sewerage coverage area of Dhaka

1

Sewage treatment plants in Dhaka

\section{3 kilometers}

Length of sewer lines in Dhaka

\section{Planned Dhaka investments}

11 new sewage treatment plants, with pipelines and networks
23,000 kilometers

of sewer network
100 kilometers

of water network 
ADB's investment program in the Dhaka Water Supply and Sewerage Authority (DWASA) provided a breakthrough in approaching urban development, particularly the delivery of clean, reliable, affordable water and to the poor, no less. And not just a breakthrough for Dhaka or the rest of Bangladesh, but for the region of South Asia. This publication looks at the key success factors that other utilities are taking note of: The zonal approach to rehabilitating and managing urban water services, trenchless technology for expeditiously laying pipes, and how to connect the urban poor-and keeping them connected-through community-managed approaches.

\section{About the Asian Development Bank}

ADB's vision is an Asia and Pacific region free of poverty. Its mission is to help its developing member countries reduce poverty and improve the quality of life of their people. Despite the region's many successes, it remains home to a large share of the world's poor. ADB is committed to reducing poverty through inclusive economic growth, environmentally sustainable growth, and regional integration.

Based in Manila, ADB is owned by 67 members, including 48 from the region. Its main instruments for helping its developing member countries are policy dialogue, loans, equity investments, guarantees, grants, and technical assistance. 